
б 





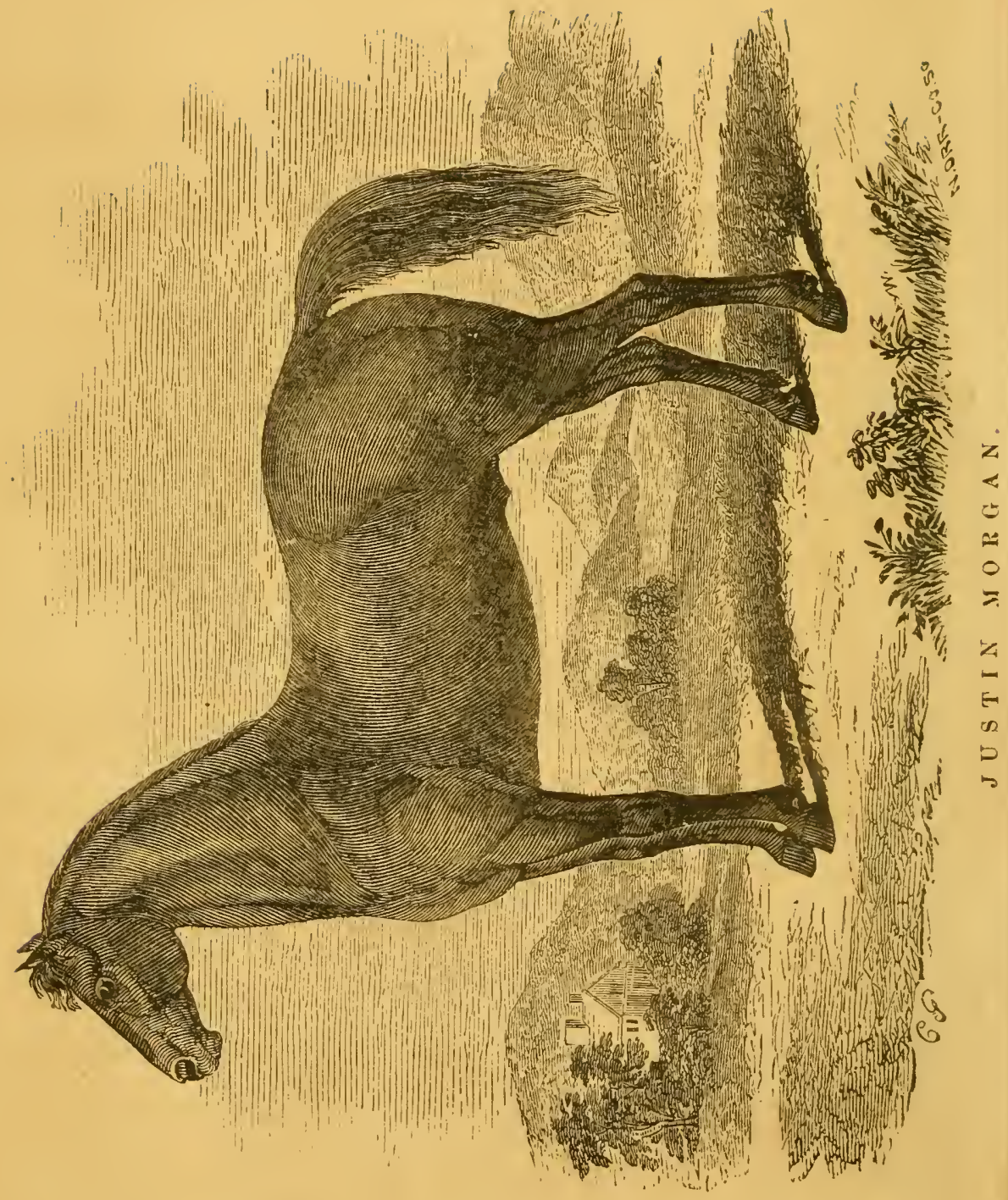




\section{MORGAN HORSES:}

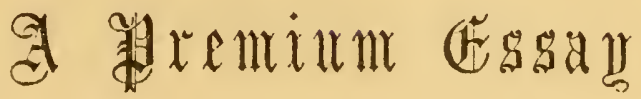

o N

THE ORIGIN, HISTORY, AND CHARACTERISTICS OF THIS REMARKABLE

\section{AMERICAN BREED OF HORSES :}

TRACING THY PEDIGREE

FROM THE ORIGINAL JCSTIN MORGAN, THROUGF THF MOST NOTED ON EIS PIROGENY, DOWN TO THE PRESENT TIJF.

\section{WITH NUMEROUS PORTRAITS}

TO WHICH ARE ADDED

HINTS FOR BREEDING, BREAKING, AND GENERAL USE AND MANAGEMENT OF HORSES,

WTTH

PRACTICAL DIRECTIONS FOR TRAINING THEM FOR EXHIBITION AT AGRICTLTURAT FAIRS.

$$
\text { D. C. L I N S L E Y, }
$$

NEW YORK:

C. M. SAXTON AND CUMTANY, AGRICULTURAC BOOK PUBLISHERS,

No. 140 Futrox Sirraet. 
Fintered, according to Act of Congrese, in the year $18 \pi \mathrm{h}$, by

C. M. SAXTON AND COMPÁXY,

In the Clerk's Office of the District Court for the Southern District of $\mathrm{New}$ Yozr.

ห. O. JFNKINS,

gintex and stexeotger,

No. 26 Franhfort Street.

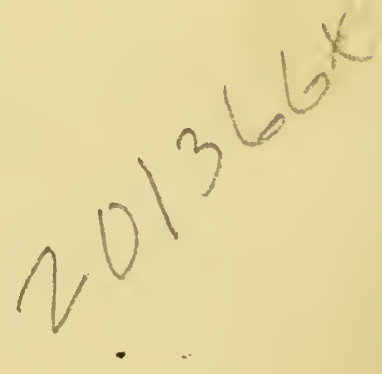




\section{PREFACE}

Morgan Horses as a distinct and remarkałue breed, originating in Vermont, and principally bred there, have long been well known to the horsemen of New England, and within a few years, to the people of the West and South, who, having become acquainted with them, have manifested a strong desire to introduce them into their sections of the country.

The author of the following work was acquainted with these horses in Vermont, and familiar with their peculiar form and action. But it was not until he engaged in the prosecution of a great public work, at the West in 1852, that he became fully aware of their extraordinary hardiness, speed and endurance, from severe use and daily comparison of them with horses of different style.

Having determined to breed from this stock, it induced a careful examination into the different families which have sprung from the original or Justin Morgan. 
In the course of these inquiries a mass of information was accumulated, with much labor and considerable expense, which was deemed too valuable to be lost.

After determining to preserve it by publication in some form, every effort was made to obtain the most reliable information upon all disputed points; in regard to the origin of the breed, the history of the most distinguished families, and their present condition.

To make the work useful to breeders who are un. acquainted with them, the peculiarities of the different families have been carefully pointed out, and full and minute descriptions given of most of the sons and grandsons of the original horse, with their pedigree, so far as it could be ascertained, and also the pedigree and description of many other stallions of the breed, more remotely descended from the Justin Morgan.

A large number of cuts have been used, most of which have been traced from daguerreotypes, and can therefore be relied upon as correct portraits of tho forms of the animals they are intended to represcut. In examination of these cuts will enable a good 
horseman to become familiar with the peculiar form which is so distinguishing a feature of these horses, and leave him in little doubt as to the cause of their remarkable qualities.

If size is, as is claimed by some, the measure of power, it will be found that form is the measure of action. Too much size is, indeed, incompatible with rapid and long-continued action.

The most casual observer of a good Morgan horse, is conscious that he sees a peculiar animal. His short, light, rapid step, point to the great muscles which give him motion. His prominent, clear, eager eyes, set wide apart,-testify to his courage and docilitywhile his clean, light head, carried high, with short, pointed, sensitive ears, gives grace and elegance to every motion.

A slight description has been given of some of the most prominent breeds of horses, that they may readily be compared with the Morgan.

The style, it is hoped, will be found plain and clear.

To the many gentlemen who have aided us in collecting the materials for this book we return our sincere thanks. Their hearty encouragement has cheered 
us in the prosecution of our work, and much of any interest that may attach to it, is due to their assistance. Should occasion offer, we trust they will afford us an opportunity to reciprocate their favors.

If the publication of this volume should prove instrumental in awakening increased interest in the breeding of these noble animals, and in leading farmers and breeders to the best sources for obtaining this stock, or in enabling them to detect the many spurious animals advertised throughout the country as genuine Morgans, the author will feel satisfied that he has not labored in vain.

\section{C. LINSLEY.}

Middeeburit, VT., September 10, 1856. 


\section{CONTENTS.}

$\begin{array}{llllllllllll}\text { Praface, } & - & - & - & - & - & - & - & - & - & & \\ \text { Contents, } & - & - & - & - & - & - & - & - & - & - & -\end{array}$

\section{CHAPTER I.}

The Most Esteemed Breeds, of Horses, snd the Kinds of Service to which they are Adapted, - $\quad$ - $\quad$ - $\quad$ - $\quad$ - $\quad$ - 9

CHAPTER IT.

Contrast Between the Kinds of Service Required of Horses Formerly, and at the Present Day, - - - - -

CHAPTER III.

Description of the Kind of Horses most sought for in the Principal Markets of the Comntry, - - - - - - - 41

\section{CHAPTER IV.}

Peculiar Adaptation of the Morgan Forse to the Road and General

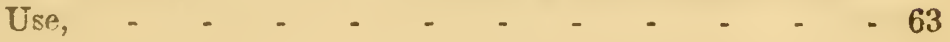

CHAPTER V.

Origin of the Morgan Horse,

CHAITIR VI.

Memnir and Description of the Justin Morgan, - $\quad$ - $\quad 131$

CIIAPTER VIT.

Mistory and Description of the Stallions Sired by the Justin Morgar, 
viii

CONTENTS.

CHAPTER VIII.

General Description of the different Fanilies and their Distinguishing Characteristics, - $\quad$ - $\quad$ - $\quad$ - $\quad$ - $\quad$ - $\quad-165$

CHAPTER IX.

Present Condition of this Stock in Vermout, _ _ - - 175

CHAPTER X.

Performances of Morgan Horses; the Lemand for them, and their Present Value as indicated by Sales, - _ _ - 185

CHAPTER XI.

Hints as to the Best Metliods for Improving and Perpetuating the Breed, - - - - - - _ - - - 200 CHAPTER XII.

Hints in Relation to Brealing and Driving. _ - $\quad$ - $\quad$ - $\quad$ - 219

CHAPTER XII.

The Proper Manner of Feeding and Driving upon the Road, - 238 CHAPTER XIV.

Hints to Purchasers of Morgan oi other Hores, _ - - - 250

CHAPTER XV.

Pedigrees and Description of Stallions, - - $\quad$ - $\quad-\quad-\quad-\quad-260$ APPENDIX, - - - - - - - - - - - 323 


\section{[EXTRACT.]}

TO THE VERYONT STATE AGRICULTURAL SOCIETY.

The Conmittee of $A$ wards, to whom was referred the subject of Essays, respectfully report, that they have attended carefully to the duties of their appointenent, and do AWARD tue First Premium to Mr. D. C. Linstery, of Middlebury, for bis elaborate Essay on the Horgan Horse.

In consecrnence of the peculiar merits of this treatise, the Committee feel anthorized to commend it to the particular notice of the Societr, as one eminently adapted to the wants of the people of this State, and as supplying a desideratum long felt, both in regard to the true history of the Morgan Forse, and in respect to the best methods of its perpetuation. We beliere Mr. Linsley has collected all the facts pertaining to his subject which intelligent research and thorough derotion can furnish; and that he has embodied then in an attractive form and with a just discrimination. The information relating to the history of the Breed is important, and, we think, can be found in no work yet published; the style in which it is communicated is clear, spirited, and in perfect keeping with the subject discussed.

When it is considered that the sources of information in regard to the origin and history of the Morgan Horse, now obscure at the best, are rapidly climinishing, and that Mr. Linsley has reseued so much, which in a short time would have been beyond the reach of the compiler, it must be admitted he has rendered a valuable service to the farmers of the State, and one which, in the judgment of the Committee, the Society ought not to Inare unrecognized. ***

January 15,1856 .

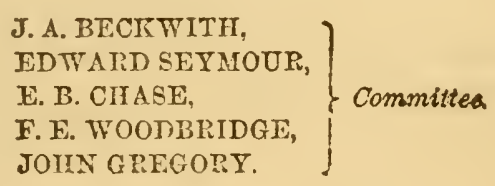


D. C. Linslet, Esq. :

Dear Sir,--Your favor of the $3 d$ inst. is at hand, as also the accompanying drawing of the old Justin Morgan. I knew the horse well, and owned him about seven years while in the prime of his life. The drawing is a very faithful representation of him as he appenred while I owned him, and I can suggest scarcely any alteration; perhaps none that would make it a more faithful copy of the original.

Yours respectfully,

DAVID GOSS.

Derby Line, VT., July 21, 1856.

D. C. Linstir, Esq. :-Your favor of the 18th inst., containing a drawing of the old Justin Morgan, has this day come to hand, and I hasten to reply. In early life it was my privilege to know the origrinal Morgan Horse perfectly well, and for some time to see him almost daily at the time of bis greatest popularity, and I have no hesitation in saying, that the drawing exhibited, in my judgment, is remarkably correct, and gives a very accurate delineation of the horse as he appeared in life.

I remain, Dear Sir, yours truly and

Very respectfully,

SOLO. STEEIE,

D. C. Linstiey, EsQ̨. :

Claremont, N. H., July, 1856.

Dear Sir,-I received a line from you yesterday, and with it a drawing of the old Justin Morgan or Goss horse. As I have before told you, I knew the horse well, having seen him often, and kept him one year while Joel Goss owned him. He was far the best horse I crer had anything to do with, and my recollection of him is perfectly elear and distinct.

The drawing you send is a very excellent likeness of him, and I am pleased to see an effort making, even at this late day, to preservo some record of him.

Yours Respectfully, DAN. BALDWIN. 


\section{CHAPTER I.}

TaE MOST ESTEEMED BREEDS OF HORSES, AND THE KINDS OF SERVICE TO WHICH THEY ARE ADAPTED.

THe history of the horse, intimately interwoven as it is with that of man, can hardly fail to interest the most careless student. From the earliest ages he has been man's faithful ally and willing slave. In war, he not only moves all the machinery of the field and camp, but shares with his rider all the fatigue and danger of battle. In peace, how various and invaluable are his services. Every branch of industry owes much to his patient toil; he ploughs the soil, sows the seed, reaps the harvest, and transports it to the distant market. From year to year, and age to age, he has toiled unceasingly for his master, in the cart, the mill, the freight-wagon, or the mail-coach. For many centuries prior to the construction of canals, almost the entire inland commerce of the world was carried on by means of the horse.

Not only has he thus relieved our wants and ministered to our comfort, but he shares with us in our pleasures and amusements; he not only works steadily and patiently in the loaded wagon, but in the race becomes as much excited as his master, and appears to rejoice in the pleasurcs of the chase. In gracefulness of motion, elegance of form, and dignity of carriage, he is superior to every other quadruped; and by those 
nations to whom he is known he is almost universally considered the most useful and manageable of all our domestic animals Hence he has been admired, cherished and loved, equally by the most enlightened and most barbarous races of men. More time, money and intellect have been used in the attempt to improve and perpetuate the distinguishing characteristics of the best breeds, than has been expended upon any, perhaps it may be safely said all, other animals. His servant in the field, his companion in the chase, and his willing slave in trials of speed, he becomes the pride, the joy and boast of his master. Boundless wealth is often scattered for pleasures and amusements, in which the flying font of the horse is the chief attraction. Attached to his master and obedient to his will, he bears him without question or murmur, through sunshine and storm, over mountains and through rivers; carries him with unfaltering nerves into the thickest of the battle, and if repulsed, his speed and endurance bid defiance to pursuit.

Hence no animal has received the same care and attention in breeding and training as the horse.

Though the horse was domesticated in the time of Moses, and is frequently mentioned in history, yet we know little of his condition, or the manner in which he was trained, until about four hundred years before Christ. Xenophon was the first writer who left us any record of what were then considered the best points of a good horse; or described, criticilly and in detail, the proper method of breaking and training him. Considering that nearly twenty-three hundred years have elapsed since this essay was written, it must certainly 
be deemed surprising that it should still be admitted as a standard authority upon the subjects of which it treats.

Among the ancients the horse was little used, except in war and the chase. For these uses the wild horses of the East are perhaps as well adapted as any other breed now in existence. The wild horse being so well suited to the wants of the ancients, no attempt would be made to improve him or alter his general conformation by careful breeding. Had other wants been felt, and efforts made to alter his general form, it could hardly have been productive of any improvement or important change; for, to be successful, the breeding must not only be continued for several generations, but must be undertaken by a people fixed in their habits, devoted to agriculture, and perfectly conversant with the $y_{\text {-eat }}$ physical laws that must be carefully observed in crossing different breeds of animals, in order to insure success. The ancients had not these advantages, and 'we think it may safely be inferred, that up to the commencement of the Christian era, the main characteristics of the horse had undergone little change, except such as had been produced by the climates in which he lived, the nature of the soil, and the pastures upon which he fed.

In the central and northern parts of Asia, and the northern part of Europe, where the climate is cold and the vegetation scanty, the wild horses were then, and are still, small, but active and hardy, with bodies closely knit, and hair thick and long. They are capable of performing the longest marches without exhibiting fatigne, are fleet, sure-footed, and well adapted 
for service in the cold and mountainous countries in which they are found.

The earliest records we have of the horse, trace him to Egypt, whence he gradually found his way to the various Egyptian colonies. Among the African varieties, the $B a r b$ is remarkable for his fine and graceful action; and is found chiefly in Moroceo and Fez. II is lower than the Arabian, seldom exceeding fourteen hands. The shoulders are flat, the chest deep, the joints inclined to be a little long, and the head very fine. He is superior to the Arab in form, but has not his speed and endurance, nor his spirit and "countewance." The Barb has chiefly contributed to the excellence of the Spanish horse. The Godolphin Arabian was a Barh, and from him has descended some of the best racing stock of England.

The Arabian horse deservedly occupies the very highest rank. So late as the seventh century, the Arabs had very few horses, and those of a very inferior quality. The horses that they obtained from Cappadocia and other neighboring countries were preserved with so much care, and so uniformly propagated from the finest animals, that in the thirteenth century they had obtained great celebrity. The Arabs divide their horses into three classes: the Attechi, or inferior breed, which are little valued, and are found wild in some parts of the desert; the Kadis. chi, or mixed breed; and the Kochlani, or thoroughbred. Many of the latter liave well-attested pedigrees extending more than four hundred years, and the Arab confidently asserts that the pedigree of his farorite mare can be traced directly to the stud 
of Solomon. More care is taken to preserve the pedigree of their horses, than the genealogies of their chiefs: these pedigrees are always reckoned from the dams. The Arabian horse might not always be acknowledged to possess a perfect form, but no one can fail to admire his inimitable head. The broad, square forehead, the short, lean, firm, and delicate muzzle, the bright, prominent, and intelligent eye, the small, sprightly, and almost transparent ears, are universally acknowledged to be unrivalled in any other breed. The fineness of his legs, and the oblique position of his pasterns, may be supposed to lessen his strength; but the legs, although small, are flat and wiry, and they are not required to carry heavy weights. The muscles of the thigh and fore-arm are strikingly developed, and assure us of his ability to perform many of the feats of strength and endurance related of him; but in reading of his really marvellous marches, we must remember that there are no watches to note accurately the time, nor rile-stones to mark correctly the distances on the paths of the desert, and we must make some allowance for the proneness of the Bedouin to exaggeration. The Arabian horse is as celebrated for his docility as for his speed and courage. IIe rarely exceeds fourteen hands in height, his body is light, his hips and loins excellent, and his shoulders extremely beautiful. It is to tho Arabian that the English are chiefly indebted for their unrivalled breed of horses for the turf and the chase.

The Dongola horses, bred in the kingdom of Dongola, and the country lying between Egypt and Abyssinia, nie somewhat celebrated for their showy appearance 
They are full sixteen hands high, with very short bodies, long necks, fine crests, and sharp, high withers; but the breast is too narrow, the quarters and flanks flat and thin, with earped or roached backs. Some of these horses were imported into England about 1825 , but were little valued.

There are several breeds of horses in India, of which the Toorky is the best, and is descended from the Persian.

The Chinese horse is very inferior, and unworthy of notice.

The Persian horse deservedly ranks next to the Arabian; his head is almost equally fine, his hip and croup better; he is more stoutly built, is equal in speed, but less enduring. Their food consists of barley and chopped straw, hay being unknown. The Persian horses were very celebrated long before the Arabian was known. They rarely exceed fourtecn and a half hands high, are full of courage, and very tractable and docile.

Turkistan has long been celebrated for producing a pure and valuable breed of horses, called Toorkomans. They are large, standing from fifteen to sixteen hands high; are swift and remarkably cnduring. They are said to be preferable even to the pure Persian for severe service. They are too small in the barrel, too long in the legs, and their heads are large and clumsy; yet they are highly esteemed.

The Flemish and Dutch horses are very large, strongly and symmetically formed, with fine crests and plenty of bone and muscle, but are a little duil in their paces, and mostly used for purposes of draft. It is 
principally from these that the celebrated draft horses of England are descended.

France contains several breeds of horses, some of which, particularly the Norman, are very valuable. The government have for some years paid a good deal of attention to the improvement of horses, but they are still inferior to the English in beauty and speed. The best French horses are raised in Limousin and Normandy. Those from the latter province are of large size, with plenty of bone and muscle, large limbs, heavy quarters, sloping croup, deep chest and deep body, but a little flat-ribbed. They are very tractable, and possessed of very great endurance, and can carry great weight at the rate of six to seven miles per hou.

Spain has long been celebrated for her breed of horses, but it is thought that they are less valuable now than formerly, having suffered under the general decline of the Spanish government. The Andalusian horse, so called from that province of Spain in which he was chiefly bred, still retains a resemblance to the Barb, to which he was undoubtedly indebted for his most valuable qualities. The Barb was brought into Spain during the first part of the eighth century. England owes much of the present excellence of her . horse to this breed. About the year 1060, William of Normandy brought a large number of horses from Spain for cavalry service, and probably these wero mostly from the provinces of Andalusia and Asturias, for, owing to the richness of the pastures, horses were much more numerous in these provinces than in any other parts of Spain.

Italian horses were formerly thought very valuable, 
but are now less esteemed. The Neapolitan horses are tolerably well shaped, and from their size and high style of action are in some demand for carriage horses.

The Turkish horses are principally descended from the Arab, crossed with the Persian, the Tartar, and some other breeds. Compared with the Arabian, the head is larger, the limbs heavier, the body longer, the shoulder not so fine, and the hips higher. 'They are, if possible, more gentle and tractable than the Arabian. The Turkish horse has contributed much to the blood of the present English race-horse.

The German horses are generally large, heavy, and slow. The Hengarian is, however, of medium size, and possessed of a good deal of speed and endurance.

Many excellent cavalry horses are bred in Holstein. They are generally bay, of good size, with small, fine heads, bold, lively eyes, have good action, and are strong and active.

The Swedish horses are between thirteen and fourteen hands high, and are remarkable for their speed and endurance.

The horses of Finland are yet smaller, not exceeding twelve hands in height; they are said to be beautiful. and very fleet.

In Iceland, though the country is mountainous, and the climate cold and inhospitable, there are yet very numerous troops of wild horses. They are very small, strong, and swift.

The horses of that part of Tartary comprehending the great plains of Central Asia, and a considerable part of European Russia, are almost in a wild state; they are small and badly made, but are very hardy and en- 
during. They are not very docile or tractable. Tar tar horses form a large portion of the Persian cavalry, being preferred on account of their great hardiness and endurance.

All the horses we have enumerated, with the exception of the German, Italian, French and Flemish, are peculiarly adapted to use under the saddle, carrying light weight; and with few exceptions they are seldom put to any other service.

The Russians have some excellent horses. The most celebrated of their breeds is the Orloff Trotter, of large size and fine action. Great pains are taken in breaking and training them, to prevent their moving in any other gait than a walk or trot, consequently some of them are fast trotters.

The English horse, on account of its just celebrity, and as the source from which the best of our own have been derived, demands a more careful notice.

Horses were exceedingly numerous in Britain at the time of its conquest by Julius Cæsar, and they were so valuable, that Cesar carried many of them to Rome. The Romans having established themselves in Britain, kept a large force of cavalry there, and these horses, gathered from all parts of the Roman Empire, mixed with the native breed. Whether this cross resulted in any improvement cannot now be ascertained. The next importation of which we have any account was early in the tenth century. Hugh Capet, of France, made Athelstane a present of several German "running horses." About the middle of the eleventh century, with William the Conqueror came a marked improvement in the English horse. His followers, 
coming from a country far in advance of England in the science of agriculture, were of great service to the English in improving their horses, by introducing the Spanish horse. The first recorded importation of an Arabian horse took place in 1121-Alexander I., of Scotland, having presented the church of St. Andrew with an Arabian horse, "decked in Turkish armor, and costly trinkets." About the close of the twelfth or beginning of the thirteenth century, King John imported one hundred stallions from Flanders, and thus laid the foundation of the draft horse, which has since become so celebrated. In the beginning of the fourteenth century, Edward II. imported thirty war horses, and twelve draft horses. Edward III. purchased fifty Spanish horses, which cost him about seven hundred dollars each.

The English had used horses from Turkey and Barbary, to improve the native stock, but up to the time of James I. with but little success.

About 1610, James purchased a celebrated Arabian horse of a merchant named Markham, for which he paid five hundred pounds. After this, James purchased of Mr. Place, a beautiful horse called the White Turk.

Not long after this, the first Duke of Buckingham im. ported the Helmsly Turk. These two animals produced a great change in the character of the English horses.

Charles I. eagerly pursued the favorite sport of the English gentleman, and established races at Hyde Park and Newmarket. Cromwell was himself anxious to continue the improvement of the horse, and kept a stud of race-horses; but racing was not countenanced by his party, and the race courses were closed. 
At the Restoration in 1660 , a new impulse was given to the cultivation of the horse. Race courses were opened, and royal plates were now given at the principal ones. Charles sent his Master of the Horse to the Levant, to purchase both mares and stallions. These were principally Barbs and Turks. His nobles followed his example, and from that time until the eighteenth century almost every valuable variety of Eastern blood was from time to time engrafted on the old stock. In 1703, Mr. Darley imported the Arabian that has since borne his name, being then four years old. About twenty-five years later, a Mr. Coke brought the Godolphin Arabian from France to England, and presented him to Mr. Williams, Master of St. James' Coffee House, who presented him to the Earl of Godolphin. It is to these importations chiefly that is due the high degree of perfection which the English racehorse has attained.

The English Hunter is not as distinct a breed of horses as has often been supposed. Every variety of blood has been resorted to, to produce the horse best suited to the work required of him, and he is now usually three-quarters thorough-bred. Mr. Slinner says the Hunter is but a combination of the race-horse or thorough-bred, with one of less blood. Formerly, hunters were bred from coach mares, or "Machiners" as they are called; but now the hunter is lighter, and inore nearly thorough-bred. Many of the hunters of fifty years ago were bred by crossing the Cleveland Bay with the race-horse; and resembled the best Hack. neys of the present day.

Of the Hackney, a standard English work says: "The" 
Hackney should be a hunter in miniature, with theso exceptions: his height should rarely exceed fifteen hands and an inch. He will be sufficiently strong, and more pleasant for general work, below that standard. He should be of more compact form than the Hunter-more bulk according to his height, for he has not merely to stand an occasional though severe burst, but a great deal of every-day work."

The English coach horse was formerly bred from the Suffolk, and the Cleveland Bays (breeds now nearly extinct) by crossing the mares with horses possessing more or less racing blood, and was, in fact, but a large, heavy Hunter or Hackney.

The Cleveland Bays, the Clydesdale, the Northamptonshire, the Suffolk Punch, and the heavy Black, or Lincolnshire horse, are but different varieties of the English draft horse, and are but little used for any other purpose.

The coach horse, and the draft horse, have diminished very rapidly of late years, having given way to a lighter, and faster animal.

The foregoing glance at the most important races of horses will, it is hoped, enable the reader to form a tolerably correct idca of the main sources from which our horses are derived.

The wild horse is found in great numbers in Tartary, in some parts of South America, and a few in the south-western territories of the United States. In none of these can we recognize an original race. The horses of the Ukraine, and those of South America, are equally the descendants of those which have escaped the slavery of man. The former are thought to be de- 
scended from horses that were employed in the siege of Azoff, in 1657; but were turned loose for want of forage. The latter are descended from animals imorted by the Spaniards, and they still retain, almost unimpaired, the size and form of the stock from which they sprung. They are not remarkable for their speed at short distances, but possess great endurance; and many instances are recorded of the natives pushing them over one hundred miles without drawing rein.

In our own country we have several breeds of horses.

The Conestoga horse is found chiefly in the Middle States, but is not as often met with now, as formerly. He is descended from early importations from Flanders and Denmark; he is inclined to be too long in the leg, too light in the barrel, and too dull in his paces. His quarters and shoulders are generally good; and when his body is found sufficiently deep he makes an excellent draft horse; he is often over seventeen hands high.

The English thorough-bred is found in perfection in many of the States, but is bred chiefly at the South. In most of the States, the great majority of the horses in ordinary use possess traces of racing blood.

The Canadian horse is found chiefly in Canada, and is undoubtedly of Norman-French descent, and to this day they preserve, in a high degree, the distinguishing traits of the stock from which they sprung. There are many varieties, some having been crossed with the English thorough-bred. They have maintained the good qualities of their ancestors, but have less size, probably owing in a great measure to the rigor of the climate, and their scanty fare. They are exceedingly 
hardy, easily kept, are long-lived, and perfectly gentle and docile. Some of them are celebrated for speed at short distances, but as a breed they are not good roadsters.

The Narragansett pacer, a breed long celebrated in Rhode Island, is said to have descended in part from a horse imported by Gov. Robinson from Andalusia in Spain. They were noted for their easy pace under the saddle, docility, and powers of endurance. They were small and not well adapted for draught.

The Norman horse has not yet been extensively bred in this country, but a few fine animals have been imported. They are large, usually full sixteen hands high, compact and muscular; and though not adapted to high speed with light weight-yet it is believed they are unrivalled in their powers of endurance, carrying a great weight at the rate of six or seven miles per hour.

In addition to these varieties, there are in various parts of the country families claiming more or less alliance to the thorough-bred. Of these, the Messengers, the Hamiltonians, the Henrys, the Bellfounders, are perhaps the most noted, as they were generally well-formed, fine-moving, fast-going, and enduring horses.

Hamiltonian or Hamlintonian was got by Diomed, sire of the celebrated Sir Archy. Diomed was by Florizel, he by King Herod, he by Tartar, and he by Croft's Partner, who was by Jig, a son of the Byerly Turk; dam by Spectator, g. dam by Blank, go. dam by Childers. Dam of Hamiltonian was by Shark, g. dam by Apollo. Hamiltonian was long owned by Col. 
Tayloe, of Virginia, and run by him with much success. He was bred by Mr. Thomas Hamlin, from whom he was named; but of late the stock has been called Hamiltonian. He was chestnut, of good size, and was foaled in 1800 .

He had an excellent figure and good constitution, and he ran several successful four-mile races. His stock was excellent, but has been frequently confounded with that of Hambletonian, a son of imported Messen. ger.

Hambletonian, by Messenger, was a fine horse, and left some very valuable stock that has been a good deal scattered throughout the States of New York and western part of Vermont; and we think much of the stock in these States called Hamiltonian or Hamlintonian should be Hambletonian. We have not at hand the necessary data to give his pedigree or any further description of him; which we regret, as his descendants have been deservedly esteemed for their speed and power of endurance. Many of them are large, and make excellent carriage horses.

The pedigree and some description of several other noted horses will be found at the close of the chapter on Pedigrees.

The stock descended from Messenger, Hamiltonian, and some others, proved very valuable; many of them were excellent roadsters, and some of them were fast trotters. Hence, it soon became policy for dealers to advertise their horses as descended from those whose stock was known to be good; and at the stables of those dealers whose honesty is not of the adamantine kind, you can usually purchase a horse of any of the 
well-known families provided you give a reasonable hint of the stock you prefer. Hundreds of horses are sold every year as Morgans, Messengers, Hamiltonians, \&c., who have not a particle of the blood they are represented to possess.

Messenger was a gray, fifteen and three-quarters hands high, and stoutly built. He was got by Mambrino, he by Engineer, and he by Sampson, dam by Turf, his grandam by Regulus. He was foaled in 1780, and bred by John Pratt, Esq., of Newmarket, England. He ran several successful races, and finally, in 1785, won the king's plate. He was imported into New York by Mr. Benger. The first two seasons after his arrival, he was kept at Shammany Bridge, near Bristol, Pennsylvania. Mr. Henry Astor then purchased him and kept him on Long Island for two years. About this time Mr. C. W. Van Ranst, Esq., purchased an interest in him, and for the remainder of his life he was kept in various parts of the State of New York, with the exception of one year at Cooper's Ferry, opposite Philadelphia.

He died January 28, 1808. His stock were cele. brated as roadsters rather than racers, though he was sire of Miller's Damsel and some others of note. Whether animals of either of these families can now be found possessing sufficient resemblance to one another, and enough of the blood of the ancestor from whom they derive their name, to render it possible to establish a distinct and permanent variety, we are un. able to say, but think it doubtful.

The observant traveller through the different States of the Union, who possesses any taste for a horse, can- 
not fail to mark the striking difference in the general character of the horses of different sections of the country. In the New England States he sees a compact, hardy stock of horses of medium size, with high carriage-good travellers, and extremely gentle and tractable driving horses.

In almost every county he may find descendants of the Justin Morgan, and in some he will see that they comprise a large portion of the stock. Along the Canada border he will see many specimens of the FrenchCanadian horse, and in some parts of Massachusetts and Connecticut he will see descendants of the Norman, the Flemish, and the Danish horse.

Throughout New England he will see evidences of the blood of the English racer, and the Arabian; Mes. senger, Dey of Algiers, Hamiltonian, Cock of the Rock, Henry, Post Boy, Sir Walter, Sir Charles, and many others, having mingled their blood with the common stock of the country, but the pure thorough-bred he will not be apt to see. Passing through New York, we see a greater variety of horses. Within the State may be found individuals exhibiting the form and characteristics of every breed known in this country. As a general rule the driving horses (many of them very fine) are taller than those of New England, and less compact. The farm and draft horses are generally larger, but vary much in size from the Canadian pony to the English cart horse. The thorough-bred may occasionally be met with, though not so common now as formerly; but scattered throughout the State may be found the descendants of Messenger, Eclipse, Henry, Duroc, and other celebrated horses of that breed. In 
the central and northern parts of the State may bo seen some of the descendants of the Justin Morgan, some of these horses having been taken there within the past few years.

As we pass through Pennsylvania and Ohio, we observe a more striking change in the character of the horses. The fine driving horse is more rarely seen. The farm and draft horses are much larger, and sometimes are really immense. They are descended from the Elemish and Danish horses, are usually fat, slow and awkward, are sometimes pretty well formed, but are inclined to be leggy and loosely built.

In the eastern part of Pennsylvania and northern part of Ohio, many fair driving horses may be seen, but in the western part of Pennsylvania and southern part of Ohio, good buggy horses are not commonlight wagons are not much used. Many good saddle horses may be found possessing more or less of the characteristics of the English thorough-bred, a good specimen of which may occasionally be seen.

As we go west and south we find the good buggy horse becoming more and more rare, and the number and quality of the saddle horses constantly increasing; until arrived in Kentucky and Temnessee, the former is not often seen, while the latter are both numerous and excellent.

Many of the draft and carriage horses used in Kentucky, are brought from Ohio and Indiana, and are taken from the same stock of those States, the coarsest being used for draft and the finest for the carriage.

The horses in common use for farm and similar work, are decidedly inferior. This is, perhaps, in a great de. 
gree, due to the fact that a large number of the best mares are constantly used for breeding mules, and that more attention is paid to raising the latter animals, which have become one of the great staples of Kentucky.

Throughout the remaining Southern States the animals used upon the farm and road are principally inules; light wagons are but little used ; the white population is more thinly scattered; and though most of the planters keep a family carriage, yet the ordinary business travel is principally upon horseback. Throughout the Southern States the English thorough-bred is found in high perfection, and many of the horses in common use partake largely of his blood.

The horses of Indiana, Illinois and the other Western and North-IVestern States, closely resemble the horses of Ohio, and in faet, many of them were raised in that State, and taken farther west by persons emigrating to new lands.

Although emigration has been going on for some time from New England to these States, yet until within the last few years the emigrants very rarely took any animals with them, the journey being too long to be undertaken with teams; but the emigration to that country from Ohio, Pennsylvania and Virginia, has very generally been made in wagons, the emigrants taking their horses with them.

Within the last few years a few Morgan horses have been taken into that section, where they command high prices; and as they become more and more known, so the demand for them is steadily increasing, and in 
passing through the large towns the traveller will occasionally see a good specimen of the race.

It is a fact worthy of note that the English thoroughbred is found most numerous, and in the greatest perfection, in those States where the saddle horse is most in demand, and where the light buggy has not yet come into very general use; while in those States where the horse is little used under the saddle, but almost entirely in harness, he is not often met with. 



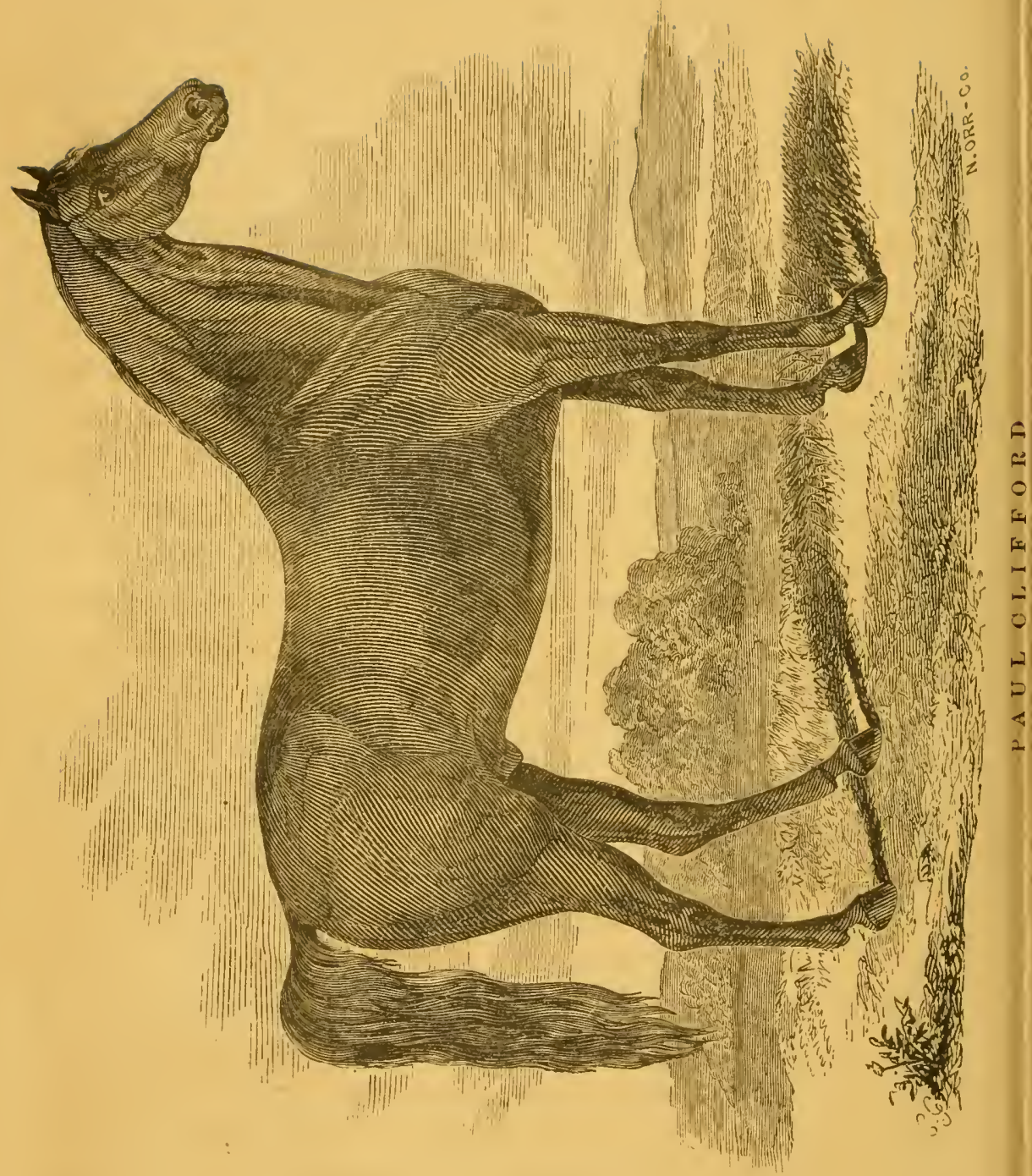




\section{CHAP'TER II.}

CONTRAST BETWEEN THE KINDS OF SERVICE REQUIRED OF HORSES FORMERLT, AND AT THE PRESENT DAY.

UP to the tenth century the Arabs alone seem to have taken much pains in breeding their horses, and the crosses of the different breeds in Europe were due more to chance than to any matured plan of improvement. The warlike sports of the joust and the tournament, which originated in France, reached their full perfection in that country during the tenth century, and by the close of the twelfth had extended over Europe.

Success in these contests depended as much upon the power and activity of the horse, as upon the skill and strength of the rider. Every effort was made to procure the finest horses by those who engaged in these sports. At first the Spanish horse was almost exclusively used.

The motley assemblage of people from every nation of Europe, to form the armies engaged in the crusades, brought together horses of every known variety. The knights of the twelfth and thirteenth centuries were almost constantly engaged in a fierce struggle with the Saracens, or in the warlike sports of that age. The announcement of a "passage at arms" drew them 
together from the most distant points. The knights had increased the weight of their armor until it alone was an ample load for the horse, consequently animals of great size and strength were needed; and it soon became evident that neither the Andalusian, the Turkish, the Arabian, nor the English horse, was able to cope successfully in the crushing charge of the tournament with the much larger and stronger, though less spirited and active horses of Lombardy, Norman. dy, Flanders, and Denmark. It was this size and strength, combined with symmetry of form and good carriage, that caused these horses to be much sought after by the knights and nobles throughout Europe.

It must not be forgotten in considering the services demanded of the horse in that age, that it is not probable he was used for field labor on the farm before the commmencement of the eleventh century, and we have no notice of his being put to such service until 1066. Horses were at that time little used except under the saddle, for ordinary travelling, for cavalry carrying heavy armor, and for heavy draft.

About the middle of the fourteenth century the use of gunpowder for military purposes, and the decline of chivalry with its accompanying martial sports and exercises, produced a great change in the horses used for cavalry, and by the nobles and gentry of Europe. Cavalry no longer derived its chief efficiency from the size and strength of the horse, which was necessary to enable him to carry the two or three hundred pounds of armor that was sometimes put upon him.

This armor, encasing both horse and rider, was almost impervious to any weapons that had before been 
used, but afforded little protection from musketry, and. was of course utterly useless when exposed to artillery. The horses, large, clumsy and awkward, were incapable of executing evolutions rapidly, or of going into action at anything. but a moderate pace; and they rapidly fell into disuse, their place being supplied by a much smaller and more active horse.

For cavalry of the present day a horse of medium size is required. He carries no defensive armor. The principal purposes for which cavalry are now used are, keeping open communication between different bodies of infantry, and patrolling the country. In battle, they are usually hold in reserve to take advantage of any momentary confusion in the ranks of the enemy, and the success of an attack at such a moment depends in a great measure upon the promptness and celerity with which it is made. Finally, they are of great service in following up the success in case of victory, and in covering a retreat. For these kinds of service it will be readily seen that the horse most suitable must be of medium size, compact, muscular, hardy, couragcous, and active.

Since the use of gunpowder, the greatest changes that have taken place in the general character of the horse have occurred in England; and for this reason, together with the fact that our American horses are principally descended from English stock, we shall glance chiefly at the changes that have taken place in the character of the English horse, and the service to which he has been put.

At the commencement of the seventeenth century, the great mass of the horses of England, with the ex- 
ception of the thorough-breds, might be divided into two classes, viz. : draft horses, and saddle horses. The former were used for trausporting merchandise from place to place in heavy carts, to which were attached from one to six horses. As, up to that time, canals and railroals were unknown, an enormous number of these horses was required to move to the seaboard the exports of a country rich as Englard was in agricultural productions and manufactured articles; and to distribute throughout the country the imported articles received in exchange.

The great demand for these horses caused much attention to be paid to breeding them, and the best English cart horse has never been excelled for the kind of service to which he is so peculiarly adapted.

The people of that age moved but little from home; when they did, the journey was made on horseback, and for the saddle they had their hackneys, or hunters. It is somewhat difficult to distinguish very clearly between the hunter and hackney of that age, for both were usually possessed of more or less blood, and the best hackneys were good hunters.

Carriages for any other purposes than the transportation of merchandise were comparatively unknown, and the heavy draft horse, being the only one broken to harness, was almost universally used for all farm or similar work. Coaches as a public means of conveyance, were first used in France and England about 1620; but they were long in coming into general use, and in 1637 only fifty hackney coaches were licensed in London. From this time the number rapidly increased, and in 1778 there were twenty-three thousand 
in England. These were all hackney, and not mail coaches. The first mail coach started from London for Bristol the $2 d$ day of August, 1784. In forty years from that time the English mail-coaches travelled nearly thirteen thousand miles per day, and the num. ber of miles travelled daily by hackney coaches largely exceeded this. The opening of canals in France about two hundred, and in England about one hundred years since, caused a great decrease in the demand for heavy diraft horses, and the attention of breeders was turned to horses for coaches, which were then just coming into use. The introduction of steam power upon railways some twenty-five years since, soon superseded the use of coaches on all the great thoroughfares, and produced a vast change in the kind of service required of horses on the road.

The roads relieved from the heavy coaches that being drawn at a rapid rate kept them in bad condition, were much improved, and consequently much better fitted for the movement of light carriages at a high speed. Formerly the English mail was thought to travel at a rate that defied all competition, but to the traveller upon the railways, ten miles an hour seemed but a moderate pace, and horsemen, emulous of steam, inade every effort to increase the speed of light carriage horses. Horses differing from the old coach horse in size, the slope of the shoulders, and style $a_{*}^{\text {. }}$ action, grew rapidly in demand. But the English have not the same taste for pleasure driving that our coun trymen possess, and though they take a greal deal of exercise out of doors, it is generally on foot or in the saddle. 
The changes that have taken place in this country during the last fifty years, in the kinds of service required of horses, have been more rapid and marked than in England.

Fifty year's ago almost the entire inland traffic was carried on by means of horses. Excepting in the vicinity of the large cities, the roads throughout the country wore wretched, and the best consisted of no other material than the natural soil, a little raised by ditching at the sides, and forming the road-bed with the material thus obtained. Even this was often neglected, and nothing was done but to cut down the forest, and record in the proper office the course of the road. When we consider that over such roads all the freight of the country was moved upon wagons, it will not be a matter of surprise, that the rate of travel of the lightest carriages rarely exceeded four or five miles per hour.

Contracts were made for carrying the mail at this rate, and often in the thinly-settled parts of the country at even a lower speed. The wagons loaded with merchandise, and the heavy mail coaches, kept the roads in a condition that entirely forbade any attempt at rapid driving with any description of carriage. The farmers, as they were often compelled to haul their produce long distances to find a market, required a horse heavier than was neccssary or profitable for performing only their farm work, although the farm work of that day was far more severe for both the farmer and his horse, than it is now. Transporting the mails, hauling freight, and ordinary field labor, were then the principal services demandod of the horse. But 
nisw the lumbering freight wagon with its long team of slow, licavy horses, is rarely seen. The mail coach with all its comforts and annoyances, will be known to the coming generation only from history. The farm. er, instead of being compelled to transport his farm products to the largest towns or cities, now finds a ready market almost at his door, for, guided by science, steam with its giant powcr has scaled our mountains, and Arives the locomotive cheerily through almost every valley of our country, relieving the worn draft horse of his load, the panting, steaming coach horse of his mails and passengers, and bringing the dealer in produce into almost every hamlet. Science also has greatly lessened the labor of tilling the soil, has substituted the light, bcautifully-shaped, and easy-rumning iron plow, for the heavy, clumsy, and hard-running wooden one of our ancestors. Every description of agricultural implement has been remodelled and improved, until they bear little resemblance to the rude instruments used by our fathers. These improvements in all kinds of agricultural tools, wagons, plows, harrows, \&c., have very much lightened the labor's of the horse. In addition to this, the forests having been felled, the folds clearcd of the timber and stumps, and the soil being in a higher and easier condition for cultivation, the farmers have discovered that active, hardy horses of medium size, are much more profitable than the large, slow, and clumsy animals so generally in use fifty years ngo. The former can certainly accomplish more ordinary farm work than the latter. They will plow as much in all cases except perhaps turning a stiff clay 
sod; they will harrow more, and remp more; they are much easier liept, and are less liable to accidents.

When used upon the road, they are almost invari. ably better travellers; and if selected with judgment from good stock, they are fleet and tractable.

It is probably in a great measure owing to the improvement in our farms, and farming tools, that horses are now much more generally used for farm work than they formerly were. When the country was new, and the fields cumbered with huge stumps, whose tough roots spread like a net-work through every part of the soil, the ox was most generally used for plowing, for his very dulness is in such ground an advantage, as at the most moderate pace, and with the utmost care, ordinary plows and hamesses will frequently be broken, when the plow comes in contact with the stumps or roots. The substitution of the improved cultivator for the hoe, the reaper for the cradle, and the threshing-machine for the flail, has rendered the horse almost inclispensable to the farmer in the prosecution of his calling; so that whatever may be the difference of opinion as to the relative cost of keeping, amount of labor performed, \&c., horses are now almost universally preferred to oxen for a farm team.

The English race-horse or thorough-bred is less affected than any other class of horses, by great changes in the modes of public conveyances, the improvements of roads and carriages, or the introduction of improved implements upon the farm. Although most of the English horses, with the exception of the draft horse, have a greater or less infusion of blood, 
yet the thorough-bred is put to no ordinary labor, but is bred for one specific purpose, which is to win on the race-course the stakes that are offered. The nature of the qualities he should possess must depend on the distance run, and the weight carried. For while the long, leggy, light-chested horse, may be able to take a prodigious stride, and with plenty of bone and muscle he may carry a heavy weight a short distance at a flight of speed; yet he can never make four miles and repeat with the same weight, unless he possesses a deep roomy chest to give him wind, a more compact frame, and a shorter leg, that he may be able to keep up his speed without fatiguing the muscles. A century ago there were six, and even eight-mile races at Newmarket, with old horses, the ordinary races being at four miles and repeat-now the "heavy plates" are all offered to two and three-year-olds for short, single races, of from one to two miles. That this is an improvement on the score of humanity may be true; but does it not tend to depreciate the horse for those qualities that render him useful in ordinary business, by inducing the breeder to seek for and foster those qualities that give speed to the horse, and to neglect those which are indispensable to give him endurance? 'This would seem at a glance to be the inevitable ten. dency of such a change in the length of the race, and the age of the horses. But we must not stop to discuss this question, nor inquire into the causes which produced this great change in the character of English racing, however interesting such an inquiry might prove to ourselves or the reader. It will be sufficient for our present purpose to inquire whether 
there has been any change in the character of the thorough-bred, and if so, whether it has been for better, or worse. This latter inquiry is of the utmost importance to the breeder, for in England, and in our own country, many breeders have been aceustomed to believe that direct resort to the thorough-bred was indis. pensable to the production of a fine horse; acting from faith in the old adage that "blood will tell," without stopping to inquire if that blood is still the same, much less what is the true and proper meaning of the expression.

That a marked change has taken place in the character of the thorough-bred, and that the change has been a deterioration in compactness, and power of endurance, seems hardly to admit of a doubt.

A writer in the "American Turf Register and Sporting Magazine," Vol. IX., p. 9, (a paper devoted to the interest of thorough-bred stock, tells us, that "his size, or perhaps his height, has been much increased, without any diminution of his blood-like appearance, but he has lost that full, round carcase and compact form, which belonged to the horses of the olden timeand if as they now believe they have increased the speed, stride, and capacity to carry weight for short single-heat races, they have not increased their powers of endurance, or enabled them to run long repeating races at short intervals."

Thomas Emory of Maryland, certainly a most critical and eompetent judge of all the points requisite to the perfect race-horse, in a letter to the same paper, Vol.IX., p. 126, says: "The result of my examination was disappointment in my expectations of English 
race-horses. There are here and there a few specimens of the race-horse of the very highest order, but the proportion of the trash to the good, is greatly beyond. what I expected, and it is wonderful with what pertinacity some of the breeders stick to their trash. * * * * They breed for speed and ability to carry high weights at an early age for short distances; and many of them acknowledge their crror, and admit they may ere long have to come to our country for hard-bottomed horses. **** At Doncaster, I saw sold the produce of several of the large breeding studs in the contiguous counties; a few of them were good colts, many of them leggy, weedy animals, and more than half of them were so badly splented at one and two years old, as to destroy their value.

"This splenting at this age unbroke I could not account for, and could find no one who could, but there it seemed a matter of course and nobody seemed surprised at it. It was new to me."

In an essay on the improvement of horses published in the "Farmer's Magazine" (London) for 1845, the writer says the qualities required in the business horse "are speed and endurance, with the capability of carrying heavy weight, with varied pace, through deep ground across a broken country; and in order that they should possess these capabilities they should have what are commonly termed in hunter's phraseology bone, muscle, and compactness.

"It would appear that our blood stock formerly possessed these characteristics in an seminent degree; and by reference to former sporting publications, it will be seen that they were shorter in the leg, and capable of 
carrying heavy weights, and running long distances now they run with light weights and short distances, where bottom is not so necessary. Our fleetest racers were then what are now called small horses, which means that they were not the tall, lengthy, leggy racers of the present day, but compact, muscular, and remarkable for their capabilities of carrying heavy weight, and power of endurance."

Mr. Lawrence, in his "Treatise on the Horse," Vol. I., page 105, says, in speaking of those thorough-breds that fail to be winners: "As to the refuse of our studs of race-horses, it consists usually of a parcel of halfgotten, delicate, weak, spider-legged creatures, which it is a misery to see applied to any labor whatever."

Similar extracts might be multiplied indefinitely, but the foregoing seem amply sufficient to establish the fact, that the thorough-bred, or race-horse, is less compact, hardy, and enduring than formerly. It is such evidence that must establish what are the qualities of a breed of horses, and individual instances of animals of the breed-exhibiting qualities widely different from those described as characteristic of their kind, whether better or worse, are only to be regarded as exceptions to a general law.

The English hunter has undergone a change equally marked, and similar to the race-horse. The field sports now indulged in by the gentry of England, differ materially from those of their ancestors. The chase of tho prosent day is a short, but spirited and exciting race of a few hours.

It is now a common custom for the huntsmen to have an extra horse ridden by a light jockey, who, 
reeping far enough in the rear to avoid the circuitous course of the hounds by watching their turnings, and by riding at only a moderate pace, is thus at frequent intervals at hand to give his master a fresh horse, in exchange for his blown and exhausted one. Thus fresh-mounted, the chase is continued at a dashing pace, and the already heated and panting fox is soon run over, and the day's sport is ended at an early hour. The noble sport of hunting was a far different amusement with the English gentleman of the seventeenth century, and taxed to the utmost the power of endurance both of man and horse. The earliest light of morning found them gathered in the field, and the shadows of evening often put an end to the chase. If the pace was less rapid, and the sport less exciting, the former was much longer continued, and the latter was certainly more noble and manly. From this change in the character of the field sports, it can easily be understood why the horse who brought his rider "in at the death of the stag," at the close of a hard day's run over broken hills, marshy valleys, and through tangled forests, should differ materially from one equally successful in the short, but furious chase of the present clay.

The hunter of the olden time was remarkable for his stoutness and endurance, was rarely more than half, and often not more than a quarter, thorough-bred; he was short in the leg and back, with deep flanks, and muscular hips and loins; his stride was short, compared with the hunter of the present day, but he was sure footed, and his step was elastic, nervous, and untiring. The hunter of the present day is rarely less than three. 
quarters thorough-bred, is taller, longer, less compact, and sinewy, and takes a much longer stride.

The thorough-bred having, as we have shown, be. come taller, longer, and less compact and enduring than formerly, and the hunter having now more of this blood than formerly, it is plain that he must have altered still more in these respeccts.

A writer in "Bell's Life in London," in 1845, says: "It is not near so easy now as it used to be, to buy a good, strong, young hunter." William Goodwin, Veterinary Surgeon to the Queen, in an article published in the "London Veterinarian," for February, 1847, says: "It is an admitted fact by all those conversant with the horse market in England, that good horses were never known to be so scarce as they now are * * * * it being but too true that the superior riding horse or valuable hunter has become almost a rara avis as compared with former days."

The increase of blood seems not only to have injured the hunter, but also the carriage and road horse. Professor Gibson, of Philadelphia, an admirer and critical judge of the horse, thus speaks of English horses. After saying that it is not uncommon to meet with English dealers at the Irish fairs, buying horses for the English markets, he continues: "The English horse, indeed, within the last twenty years has degenerated so much, in some respects, as not to serve the many useful purposes to which he was accustomed at that period, owing to breeders having run too much upon blood. On this account it is now hardly possible to meet with any of the old stock of hunters so large and powerful, and with so much bone and sinew. * * * 
Even the carriage horses, indeed, throughout every part of England, are conspicuous for their long, low necks, slab sides, and spindle shanks, and are very inferior as a race to our own stock for the same purposes."

We have not a class of horses in this country corresponding to the English hunter, but we have the English thorough-bred; and as we have from time to time imported breeding animals from England, a similar change has taken place in our thorough-bred horses. This change may not have been so great with us, as the causes which we believe to have produced that change are here less active. No one who has paid any attention to the subject can have failed to notice that for the last twenty years racing has steadily declined in this country. We do not intend to assert that less speed is attained now than in the days of Henry and Eclipse, but that far less interest is now taken in these contests, especially in the Northern and Middle States. The trotter has been steadily supplanting the racer upon the road and turf.

This change, instead of being matter of surprise, seems to us the natural result of the substitution of the light buggy for the saddle. For the latter service the thorough-bred is eminently adapted; for the former; he is not so well fitted. 


\section{CHAPTER III.}

DESCRIPTION OF THE KIND OF HORSES MOST SOUGHT FOR IN THE PRINCIPAL MARKETS OF THE COUNTRY.

THE uses to which the horses sold in the principal markets of our country are put, are hauling omnibuses, hacks, driving in light carriages, and trucking, or moving freight from place to place, in the large towns or cities. Some horses are still used under the saddle, : but the number thus employed in the Northern States is comparatively very small, and in New England a person is rarely seen on horseback.

At the South, horseback riding is still a common mode of travelling, but light buggies are rapidly coming into use, and will undoubtedly soon afford the favorite means of conveyance, on account of the many sonveniences they offer-the comparative protection from the weather, the facility for carrying light packages and ordinary personal baggage, added to the fact that with a light carriage upon good roads, a single horse easily performs the work of two under the saddle.

Though it is undoubtedly true, yet we cannot but regret, that our countrymen at the North are losing all taste for the manly and healthful exercise of horseback riding.

All writers upon the subject of the proper mode of (44) 


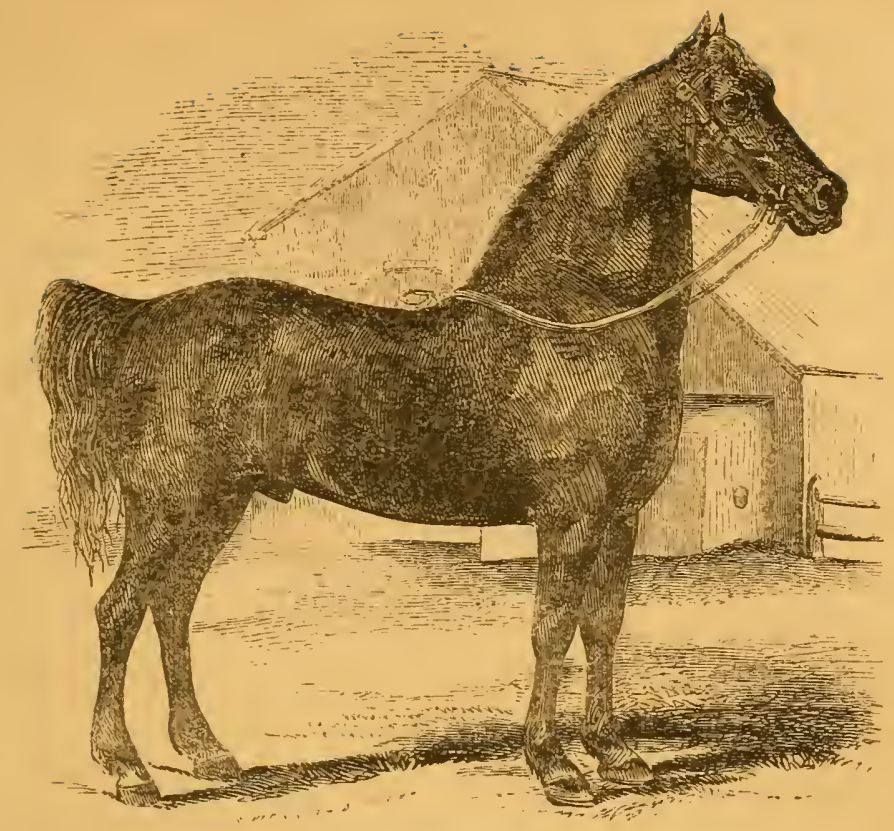

GREEN MOUNTAIN.

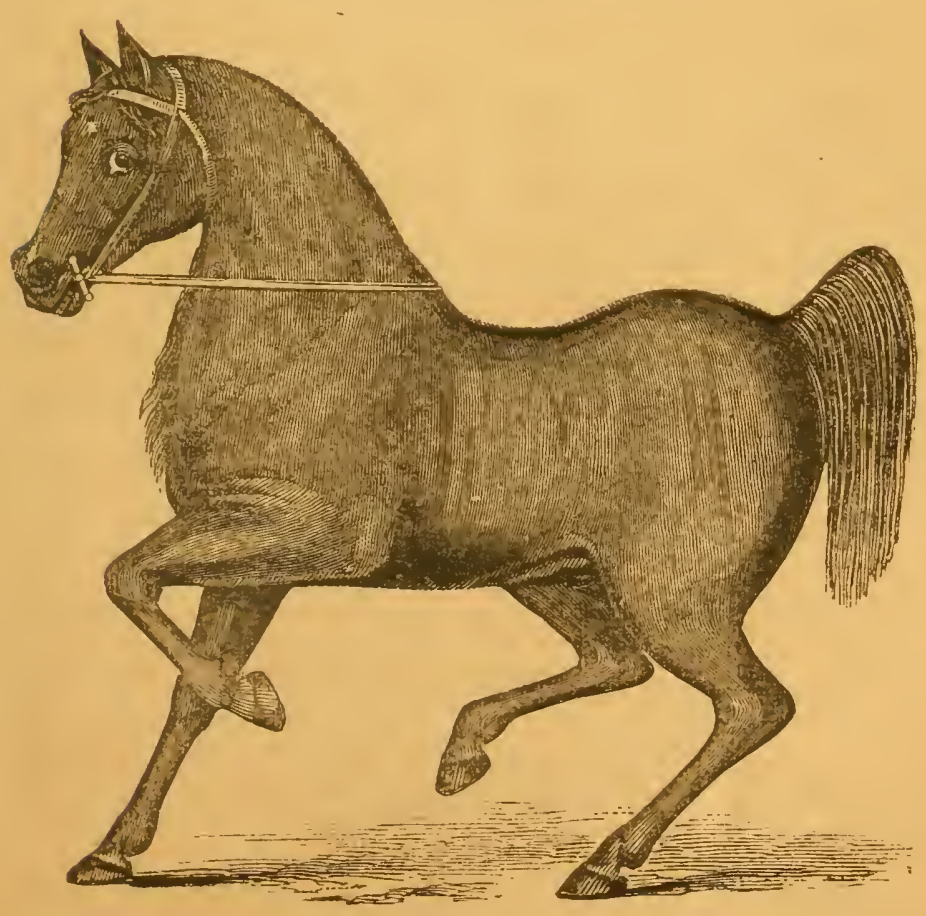

RO I I I ) . 

living, urge upon us; in the strongest language, the importance of this exercise, as one most conducive to health, and there are certainly few exercises more graceful or exciting. The healthful excitement produced by this exercise, in a bracing atmosphere, must have been felt by the writer of the following beautiful lines, or he would have been unable to describe its effects so graphically and beautifully. It was first published in 1832, over the signature of "Idler," in the "American Turf Register and Sporting Magazine," Vol. III., page 512 :

\section{MY HORSE.}

"With a glancing eye and curving mane, He reighs and champs on the bridle-rein, One spring, and his saddled back I press, And ours is a common happiness!

'Tis the rapture of motion-a hurrying cloud When the loosened winds are breathing loud;A shaft from the painted Indian's bow,A bird-in the pride of speed we go.

"Dark thoughts that haunt me, where are ye now, While the cleft air gratefully cools my brow, And the dizzy earth seems reeling by, And naught is at rest but the arching sky, And the tramp of my steed, so swift and strong, Is dearer than fame and sweeter than song?

There is life in the breeze as we hasten on; With each bound some care of earth has gone, And the languid pulse begins to play, And the night of my soul is turned to day. A richer verdure the earth o'erspreads, Sparkles the streamlet more bright in the meads ; And its voice, to the flowers that bend above, Is soft as the whisper of early love. 
With fragrance spring-flowers hare burdened the sir, And the bluc-bird and robin are twittering clear.

" Lovely tokens of gladness, I marked ye not When last I roamed o'er this self same spot. All ! then the deep shadows of Sorrow's mien Fell like a blight on the happy scene, And Nature, with all her love and grace, In the depths of the spirit could find no place.

"So the vexed breast of the mountain lake, When wind and rain mad revelry make, Turbid and gloomy and wildly tossed, Retains no trace of the beauty lost: But when through the moist air, bright and warm, The sun looks down with his golden charm, And clouds have fled, and the wind is lull, $\mathrm{Oh}$ ! then the changed lake, how beautiful!

"The glistening trees in their shady ranks, And the ewe, with her lamb along its banks, And the king-fisher, perched on the withered bongh, And the pure blue hearen all pictured below!

"Bound proudly, my steed; nor bound proudly in vain, Since thy master is now himself again.

And thine be the praise, when the leech's power

Is idle, to conquer the darkened hour-

By the might of thy sounding hoof, to win

Beauty without and and a joy within;

Beauty, else to my eyes unseen,

And joy, that then had a stranger been."

The demand for saddle horses is so small, that very few breeders make any effort to raise animals suited to this service, and even if the demand were much greater, it would hardly prove profitable; for it is difficult, by the most skilful breeding, to produce horses that will 
have the natural paces that are usually deemed indispensable to a good saddle horse. It is a slow and laborious process to teach a horse to move in a gait altogether unnatural to him, and, however well he may be trained, he cannot move easily in it.

The horses best adapted to, and most sought, for omnibus and hack use, are of medium size, weighing from ten to eleven hundred pounds. Very many of them weigh less than ten hundred pounds. For hacks they do very well at nine hundred and fifty pounds, but for omnibus service, ten hundred is about the minimum size with buyers when the market is well supplied. As omnibuses are usually heavily loaded, and clrawn at a moderate rate, it might at first seem advisable to use horses of much larger size. It would, perhaps, be more economical if the carriages were drawn over common earth roads; but the road is usually a hard, uneven pavement, and the heavy horse soon breaks up his feet, injures his linees, and becomes unfit for use. Large horse have not, as a general thing, as good feet as smaller ones, and the omnibus horse, however good his feet and knees, is very apt to injure them. To us, it is a matter of astonishment that they withstand as well as they do, the constant pounding upon the flinty pavements. For this reason, the well-formed horse, weighing from ten to eleven hundred pounds, is preferred to a larger animal for omnibus-work. The same objection applies, only with greater force, to the large horse for the hack; for in the latter carriage, the load is less and the speed greater.

The horse best suited to hack service, is well adapted to a vast many kinds of business. He must be 
hardy and enduring, a good, free driver, with high carriage, and easy action; in short, he must be a good roadster. He must also be "kind at a pull," for he will occasionally be put to one; he must be quiet and fearless, for he will be frequently required to stand by the roadside hours at a time, and he will be driven where there are ten thousand things to frighten and annoy him. With all these good qualities, his owner will find him dull of sale if his feet and limbs are not superlatively good, for to no animal are they as indispensable as to the city hack or livery horse. He is constantly driven rapidly over roads harder than iron. Often after being heated by fast driving, he will be left to cool with his feet standing in cold water, or with a stiff northwester blowing on him, and unless his feet and constitution are both perfectly sound, he will be soon used up.

The omnibus or coach horse may be straighter in the shoulder, and heavier in the forehand, than would be at all pleasant in the buggy horse, without detracting from his usefulness; but most coach and omnibus owners prefer a horse of high carriage, good action, and fine style; and it is very certain that such horses always sell readily for such service, even if doctors do not all agree that their form is the very best for their work.

For truck horses there is usually a fair demand. For this service, a heavy horse is best adapted, and perhaps the heavier he is the better, provided he is compact, well proportioned, with good limbs and feet. For this kind of service speed is not required, and the most important requisites are a good constitution, good figure, a quiet temper, and a moderately-quick walk. 
Fine, large, well-matched horses, such as are used by men of fortune in the cities before their showy carriages, are always in demand, and command high prices; but the number of horses in use for this service is comparatively small, and their labor being very light, they live to a good age, and do not require to be often replaced, as is the case with horses put to more severe service.

Horses that may be called "Sporting Horses," aro still less numerous, and always command high prices. In all the Northern cities, by the term sporting horse is gencrally understood a fast-trotting horse; but at the South, by the same term is generally understood a race-horse. It is extremely difficult to say just what rate of speed entitles a trotting horse to the distinction of "sporting horse," and if it could be stated to a second, it would be of no importance, for the standard must be constantly changing, so long as the speed of our road horses goes on increasing; for it is not the power to go a given distance, within a given time, that gives a horse this distinction, but the power to "do it" relatively quick, or quicker than the majority of the horses he meets on the turf.

A few years since, a horse that could trot his mile inside of three minutes, could fairly lay claim to this distinction; but now persons will rarely take the trouble to record his time if he cannot do it several seconds within that. We think it safe to say, that no horse can lay claim to the title of a sporting horse that cannot make his single mile in three minutes, and unless he can do much better than that he will not be called "fast." The true sporting horse is valuable 
mainly on account of his speed; and symmetry of form and elegance of style are but little considered provided he can "make time."

In all the cities and large towns there is a great demand for horses similar to those used in omnibuses, hacks, and livery stables: namely, for express wagons, butchers' carts, milk carts, bakers' carts, \&c., \&c., and the horse that is best adapted to any one of these uses will be well suited to all the rest. A liorse suited to these kinds of service, should possess an iron constitution, for he will be put to the severest kind of labor, and without this, all other good points will be of little service to him, for he will soon break down. IIs feet and limbs must be unexceptionable, for he will be driven rapidly over flinty roads, with little regard to the ascent or descent of the ground, and if they are not superlatively good, corns, sand-crack, thrush, founder, broken knees, \&c., one or all of them, will be sure to result.

Horses suitable for driving in light carriages are in great demand, and in our agricultural fiirs are classed as "Roadsters." Pleasure-driving has become a national amusement, and one for which a growing passion is to be noticed among all classes of our citizens.

This may undoubtedly be partly attributed to the easy circumstances of our tradesmen and mechanics: enabling most of them to indulge in sports and amuse. ments involving but a moderate expense, such for instance as the keeping of a bird-dog and gun, for a few days recreation in the summer, and in the luxury of a fine driving horse, with which they give their 
wives and children an occasional airing. The importance of this peculiarly American amusement can hardly be over-estimated; it affords a mode of recreation both for the mind and body, of the most pleasant and useful kind. The physician recommends it to the invalid and hyposhondriac, and the lovers of nature and the moralist seek it as their favorite mode of amusement. It performs the two-fold office of strengthening the body, and invigorating the mind.

Who has not felt the glow of pleasant excitement, and the new impulse given the blood in his veins, by a short drive of a few miles, after a good horse? Walking is by no means a substitute for it-the fact of the rapid motion, and the multiplicity of objects met and passed, constantly calling our attention to objects, only to be left again for others, each suggesting thoughts so fugitive and electrical, gives a relief to the wearied faculties which nothing else can give.

In the increase of the population of our country, there is of course a corresponding increase in the number of mechanics and professional men, whose business is all carried on within the walls of their offices and shops. To these, who form a large share of our population, this mode of exercise is most pleasant and healthy. The mechanic and merchant, after the labors of their callings, do not want recreation that will make new draughts upon their physical energies, but that which will give them rest at the same time that it gives them entertainment-invigorating them as well as affording relief from fatigue.

Doctors seem well agreed that any exercise taken 
for one's health, to be in the highest degree beneficial, must be entertaining.

Riding always has an interest within itself-the excitement of the rapid motion, the spirit and beauty of the horse, the persons we meet, the hills, the streams, the trees, all give a life and ecstasy to the exercise, that cheers and vivifies even the invalid. We had it at our pen's end to make a few remarks on the importance of this exercise for ladies, but for several cogent reasons have determined to postpone them to a more convenient season. First, because we are distrustful of our ability to throw any more light upon this veteran subject. Second, we fear we should be trespassing upon ground that belongs by right of possession to the orthodox lecturers upon the subject of physical culture; and thirdly, we firmly believe that the announcement of such an intention would cause fuur-fifths of our readers to skip the rest of this chapter, which we intend shall yet contain some important matter.

In addition to the amusement that our citizens derive from their tine horses, and light buggies, most of them make their horses useful in a variety of ways. The merchant of moderate means often keeps him constantly employed in delivering packages of goods to his customers, moving his wares from the railroad dépôt to his store, and often driving him into the country collecting his accounts, and visiting his customers. Mechanics find him useful in a variety of ways. In the prosecution of their trades, many of them are often called to practice their art at places distant from their shops, and but for their horse the time that would be 
necessarily occupied in going and returning on foot, would, in many instances, prevent their attending such orders, or they would do so at little profit. The mechanic, too, has a great variety of materials to move to his shop, and from his shop to his customers, and very many similar services, or chores, that his driving horse can do, not only without injury, but with very decided benefit. To any housekeeper, how many small sums that would otherwise be paid for omnibus-fare, to truckmen, expressmen and portere, may be saved by keeping a good driving horse. We do not wish it to be inferred that, considered only as a matter of economy, we think it would be profitable for every family to keep a horse, for the sole purpose of performing these small services; we wish merely to show how any family can indulge in the luxury of lkeeping a good horse, at a far less actual expense than might at first seem necessary.

To the butcher and the baker, a good horse is indispensable to the transaction of their daily business; and though it would seem that the butcher's horse might, without detracting from his usefulness, be a little straighter in the shoulder, a little duller in his paces, and a little heavier in the forehand, than would be desirable in the light driving horse, yet the butcher thinks very differently; in fact, there seems to be a perfect passion among this class of tradesmen for a high-headed, smooth-stepping, and fast-going horse; indeed, so great is the cmulation between them, that they will often incur great expense to obtain a "crack goer." It is a common saying, that "a butcher always drives a trotter," and many a fast young man, just 
commencing his explorations in the direction of Porter's, Brighton, or the country beyoud the head of Third Avenue, who has pulled out his nag with the utmost confidence to pass a lumbering butcher's wagon, has discovered to his mortification that they were not the safest kind of cattle to "challenge for a brush."

We think the horse well adapted to the wants of the merchant and mechanic, may be fairly considered a good type of the "horse of all work," or business horse.

Before proceeding to describe what we consider should be the distinguishing characteristics of such animals, let us fully understand what is meant by the term "horse of all work," since it has come into very general use, and is frequently used by Agricultural Societies in this country to denote a class of horses. By this term we understand that kind of horse which is best adapted to general use--to work on a farm, to go to mill, or to meeting, to haul a coach, or a buggy, to work in the field, or go a journey. This is certainly the natural meaning, and we should not have thought any explanation necessary, had it not sometimes been understood to mean such a horse as is best fitted for each of these different kinds of service.

To describe fully and correctly, all the qualities that should be found in the horse of all work, or business horse, requires that we should enter somewhat into details, for he must come up to a given standard in a greater variety of points than the horse for any other service. It is true, that many of his good qualities should be found in all really valuable horses, whatever be the service to which they are put. To illustrate our 
meaning: the good busincss horse must be a fine roadster; but a fine roadster may not necessarily be a good business horse, for he may lack that docility of temper, that quietness, and perfect tractability, which the latter should invariably possess.

First of all, the business horse should be compact. Youatt defines compactness to be: "as much goodness and strength as possible in a little space." Without this he cannot have endurance and hardiness of constitution. Next to compactness of form, he should have good limbs-a little larger than the hunter's, but the increased size should be in bone and muscle, and not in meat or hair. The limbs should be short, and the fore and hind-legs should have a proper adaptation to one another; that is, he should not have short fore-legs and long hind-legs, nor should he have short hind-legs and long fore-legs, as there should be little difference in the height of the hips and the withers, though the withers should be the highest. Horses that are highest on the hips labor much in ascending hills, though on level or descending ground they may have greater speed, but they are very liable to stumble, and are usually low-hexded and heavy in hand. The fore-legs, upon which mainly depends the safety and ease of the animal's movements, should be well spread at the chest, to give ample room for the full development and action of the vital organs. Measured at the chest, they should be a little wider from outside to outside than at the pasterns; but this difference should be owing to the prominence of the muscle of the fore-arm, more than to the general inclination of the legs inward, or towards each other This general inclination of the fore-legs towards 
each other, must be slight and barely noticeable, as much deviation from the perpendicular is a serious defect. The legs must be straight, bending neither outward nor inward at the knee, for all horses with such limbs have imperfect action, are inclined to cut (or interfere), and travel either upon the inside or outside of the foot. The fore-arm should be long, and viewed from the side, should be wide at the top, tapering gradually to tho knee, with the muscle swelling out plump and full, particularly in front. The knees should be wide and flat, free from flesh, clean and compact, with the hinder-bone prominent. The knees being less liable to injury than the hocks, too little attention is generally paid to their form, and provicied they are not "sprung," the purchaser is generally satisfied. The cannon (or the bone between the knee and the fetlock, should be short and free from meat; the back sinews should be large and flinty, and should stand well out from the bone. Viewed from the front, the legs should be thin; viewed from the side, they should be wide and sinewy. The contrary formation, or "tied in back sinews," is a very serious defect, and it is almost impossible that horses with this conformation should be capable of great endurance. The fetlock should not be round, but rather wide, and thicker in front than behind. The pasterns should be short, not upright nor very sloping, for if upright, the joints will be liable to injury from the concussion attending every step; and if, on the other hand, long and sloping, it denotes weakness.

Mr. Minds, in his work on Farriery, says: "Horses having long and sloping pasterns soon tire, and I may say are generally weak, having the flexor tendon or 
back sinews considerably relaxed." It is impossible to describe exactly what should be the length and slope of the pasterns. In horses intended for very fast work the pastern should be moderately long and sloping, as it gives more elasticity to the step and ability to take a long stride. Large horses should have more sloping pasterns than smaller ones, as their greater weight will add to the concussion in travelling. The hoof should be nearly round, open at the heel, smooth and hard, but not brittle, without any bunches or depressions in front, or at the quarters; should be straight in front from the hair to the toe, and not be too high behind.

The shoulders should be long and oblique, thin and flat at the withers, the point pretty low and well forward. They can hardly be too oblique for the road horse, and are not objectionable except when the horse is wanted for heavy and constant draught. The hips should be long, wide and muscular, the croup a little sloping, the quarters full, wide at the stifle, the stifle-joint well forward, and the muscles of the thigh should continue plump and full, well down to the hock. The hock should be wide, short, free from all lumps, the muscles comnected with it clearly defined, and the point should be long. Below the hock, the hind-legs should resemble the fore-legs; they should descend perpendicularly, and the hocks should not be nearer together than the fetlocks; it is less objectionable to have the fetlocks nearer together than the hocks, but the nearer they approach the perpendicular the better.

With such formed shoulders as we have described, the neck will almost invariably be well-placed, and the 
head carried ligh. The neck should be of moderate length, tapering well towards the head, slightly crowning on top, and very slightly curved underneath. On such shaped necks, the head is almost invariably well placed, with the muzzle neither too high, nor too low, not too much projected forward, nor too much drawn in towards the chest. When the neck is very short, the horse is apt to be heavy in hand, and want sensitiveness to the rein; it also gives the animal an awkward. and uncouth appearance. The head should be small, lean, and tapering rapidly from the jowls to the muzzle; the jowls should be thin, but muscular, and the jaws well apart. The profile should be straight, neither "hollow-faced" or "Roman nosed" — both are unsightly, and the Roman nosed horse rarely has a good nostril; the forehead should be long and broad, the muzzle thin, the lips small and firm, and the nostril full and prominent, showing a bright red membrane on the inside. But the eye and ear are the most important features of the head, and it is from these chiefly that we form our opinion of the horse's temper and disposition. The eyes should be placed wide apart, should be full, large, and prominent, with an expression which it is almost impossible to describe, for it is susceptible of almost as many different shades as the eye of man. It should be roving, bold, and eager, but mild and pleasant; the lids should be well open when at rest, for horses who keep the lids partly closed will generally be found dull in their paces, and sullen in their tempers. The ears should be small, clean, free from many long hairs on the inside, be thin and upright, and have a fine taper from the root to the tip, which should be 
pointed and turned a little inward. It is not a serious objection that they are a little large, provided they are upright, fine and lively. They should set well apart but not very wide, for when close together they indicate a timid and skittish disposition, and when very wide, they are generally thought to indicate a sluggish and stubborn temper; besides this objection, when very wide apart, they set so much on the side of the head that they appear unsightly, being inclined to lean out and become "lop-eared." The back should be short and nearly straight, the withers high and thin; the body should be deep at the shoulder, the barrel round, the ribs starting from the back-bone in a direction nearly horizontal, forming what is called a broad back; the back and hips should be well joined or coupled; there should be no depression just forward of the hip-bones, but it should keep up plump and full; the loins should be wide and muscular, and the hindermost rib should come out near to the hip-bone, such horses being called "well-ribbed up." The flanks should be deep and full. The mane should be pretty long and thick, but not so long and thick as to appear heavy. The tail should be full, heavy, and carried well up. He should be between fourteen and a half, and fifteen and a half hands high-rather a little under than much above this height, and should weigh about ten hundred and fifty pounds; his hair should be short, soft and glossy.

Such an animal, we should expect, would prove him. self a fine roadster; but we might be disappointed, for though we think it cannot be successfully denied, that such a form as we have clescribed would be well adapted 
for easy motion, and endurance on the road; yet he might not, after $\mathbf{n - 1}$, have the requisite courage and nervous energy; he might take up his foet too high and put them down with a sort of thrust, which requires a great and useless expenditure of muscular exertion, besides wearying the whole system by the constant and unnecessary jar; or he might have some other awkwardness of gait that would prove a serious objection. Nor can we always judge correctly of a horse's courage and spirit from the closest examination, without a trial of Lis powers.

An English writer, in speaking of this matter, says: "Equally true is it, that after we have approved of the proportions of a pair of horses, in respect to bone and build, certain porers of lastingness are frequently discovered to be possessed by one so much beyond his mate, that we are compelled to admit theso powers do reside in something else than his build." So trie, indeed, is it that the power of endurance-the courage that never flinches while a breath can be drawn-cannot always be discovered except by actual trial, that some of those horses which have performed the most astonishing feats on record, were passed for years by the best horsemen as animals possessed of no extraordinary powers. The great Eclipse, whose very name is used as synonymous with greatest speed and endurance, was cast by the Duke of Cumberland, when a colt, on account of his apparent deformity, and was sold by him for forty-five guineas. In addition to his apparent deformity, he was a thick-winded horse, or in other words, a "roarer." Yet in four-mile races he distanced, 
with the greatest ease, the finest horses upon the English turf. Our description, therefore, would be incomplete, without describing his gait and temper.

In harness, when the reins are taken up, and he is told to go (he should not start before), he should raise his head a little above its position when at rest, keep it there steadily and quietly, and move off nimbly, with a light, but steady, and yielding pressure upon the bit. His feet should be raised only enough to clear the ordinary inequalities of the ground, carried well forward in straight lines, swinging neither out nor in, and be set down evenly, so that the entire sole comes upon tho ground at the same time. If the heel is set down first, it is liable to injury from the tenderness of the parts; and if the toe is set down first, the horse will almost always prove a stumbler. T'he fore-legs should bend well at the knee, insteacl of the legs being raised principally by the movement of the shoulder-joint, and the leg carried stiffly forward, causing an unsteadiness of motion and a sort of rolling from side to side. The hind-legs should take up light and quick, be carried well forward under the body, and should have a peculiar, nervous, springy "pick-up," but without any hitching, or twitching of the muscles of the haunches. The step should not be long, and yet it may be too short; observation can alone deternine when this is right. This much is certain, that when there is an apparent effort to reach the full length of his step, it is too long; and when there is any cutting off of the natural stricle, as is the case with the foundered horse, it is too short.

Of color, we shall only say, that he should have some 
dark coır, for this is so entirely a matter of taste that any remarks we might offer would, after all, be little more than an assertion of our own preference, and we have sometimes been inclined to adopt the creed of a thorough horseman of our acquaintance, which is, that "a good horse is always of a good color."

Such a horse as we have attempted to describe, we feel the greatest confidence in asserting, will prove admirably adapted to all ordinary kinds of service. When used upon the road, he moves off easily, quietly, and freely, without the least disposition to fret, at a lively pace, on a pleasant rein; but when roused a trifle by an increased pull upon the bit, and an urging word, his head raises higher, his eye dilates, and he is at once a full hand for the best horseman; the taller, more open built, and longer horse, with a long, reaching stride, may easily dash by him at the first start in the morning; but if their course is the same, and the journey be continued for a day or a week, he will have ample opportunity to renew the acquaintance. Such horses will be hardy, rarely affected with any complaint, easily kept in good condition, will be always ready for use, and easily taught to perform almost any kind of service, with ease to themselves, and pleasure to their. owners. 


\section{CHAPTER IV.}

PECULIAR ADAPTATION OF THE MORGAN HORSE TO THE ROAD AND GENERAL USE.

Iv the foregoing chapter we have endeavored to describe what we considered should be the form and characteristics of the business horse, or horse of all work. Assuming that the reader is satisfied with the general soundness of the views there expressed, we now proceed to compare the Morgan horse with the standard of excellence we have there set up. First, as to compactness of form: This we have considered a primary and indispensable requisite in the business horse, and in this respect the Morgan particularly excels; his body is not remarkably long, but round and deep at the chest, the quarters large and full, the shoulders and hips well shaped, the loins wide and muscular, the flanks deep, and the whole form swelling with muscle and life.

There is not a single feature of his frame but gives unmistakable evidence of his vigorous health, and iron constitution; and though he has been, and is still, prin. cipally bred in the States of Termont and New Hampshire-States that are notoriously hilly and mountainous, and where consequently every description of work to which he is put is more than ordinarily laboriousyet he is remarkably long-lived, and in his age retains his spirit and vigor. 
Still another evidence of the soundness of his constitution is found in his almost universal freedom from every species of disease. Before railroads had taken the place of the stages, a great many of these horses could be found in various parts of New England that had been running for several years before a mail-coach, yet were perfectly sound, in vigorous health, and still as free in spirit as when first broken to harness. We have seen them running daily in the stage in fine condition when twenty years old, making daily trips of sixteen miles each in two hours, over a broken and mountainous country.

A single instance will illustrate both their endurance and style of going. A few years since, late in the month of September, in company with several gentlemen, we made a trip to the White Mountains. Having made the customary examinations in the orthociox way, we arrived late one evening at the Franconia "Notch House." Here we learned that the stage would leave for St. Johnsbury the following morning on its last trip of the season.

This being the route we proposed to take, we engaged our seats, and the following morning about 9 o'clock, six good-sized individuals (besides the driver), with our baggage, were stowed away in a snug, rugged looking stage-wagon, to which was attached a pair of horses of medium size.

The near horse was of a deep chestnut color, about fourteen and a half hands high, very closely and com pactly made, with clean, small head, and exceedingly small ears, set pretty wide apart, but very lively and active. The other animal was a gray mare of about 
the same weight, but at least half a haud higher. Sto had a fine long hip, and a good hind leg, her shoulters were well shaped, better at the with rs than the horse, and she was on the whole a very fair animal, although her general muscular derelopment was decidedly inferior to that of her mate.

We all objected to starting with so small a team over the hilly country we knew we had to cross; but these remonstrances availing nothing, my companion and I, who occupied the front seat, fell to discussing the chances of getting on with our "infant team," as he called it, and from this to discussing the relative merits of our nags. The mare was restive, eager and impatient, and my friend declared with great confidence that all horse-flesh of her dimensions could do, she would.

My own fancy had been taken by the full, brilliant, but pleasant eyes, that stood out large and full, the ever-restless ears, and the strong muscular loins and quarters of the chestnut. Accordingly I proposed to "back the horse," much to the amusement of most of the party. Our driver, after several "false starts" from the bar-room, finally took up the reins and "gave them the word."

The mare dashed ahead as if she would pull the driver from his seat. The horse struck out with a short, nervous step, but did not seem much inclined to pull, or move at any but a moderate pace. The mare took us along over the first half mile almost entirely by the bit, and my companions had a hearty laugh at my chestnut horse.

A half hour passed, and with it some five miles of 
our road. By this time "bets were not so freely offered on the mare;" she had fallen off in her pace, prespired freely, moved unsteadily, and every few moments gave her head a toss that plainly told she was beginning to lose her relish for the work. The day was hot. The horse had worked more freely as he grew warm, but not a muscle moved-save those of his ears-which was not indispensably necessury to give him motion. Thus we kept on for about twelve or fourteen miles to the end of the first stage, the mare fully satisfied, and panting with heat and exertion. Here we were to have a fresh team, but one of them being very lame from a sprain, the driver put in only one, and drove the chestnut through to St. Johnsbury.

This seemea pretty hard, but the horse did not appear to mind it in the least, and up the long hill as we entered St. Johnsbury he pressed on at the same short, nervous trot he liad kept almost the entire way. As we stepped out at the hotel we all took a good look at him. His general appearance was that of a horse about ten years old, but what was our surprise when upon speaking of him to my friend Dr. S-, we learned that he was one of Sherman's sons, eighteen years old, and had been running constantly nearly eleven years in a stage team.

The limbs of the Morgans are large in proportion to the size of the animal, but they are free from meat, remarkably wide, flat, and sinewy, with the back sinews standing well out from the bone. The joints are very close, the pasterns short, the feet rather small, but almost invariably excellent. A good many of them have considerable long hair about the legs, and this 
we do not like, as it detracts from the beauty of the animal, and retains the moisture about the limbs longer after the animal has been exposed to the wet. True, if carefully groomed, they will not be left wet, but it is a melancholy fact that grooms are not always thus careful. Where the limbs are otherwise unexceptionable, we do not consider this a very serious objection, especially in horses whose legs are short, the vital energy great, and the circulation consequently good.

The shoulders are large and muscular, the blade sloping well back, the point low and well formed, and the breast broad, giving a deep, wide, roomy chest. The hips are long, deep, and wide, the loins are broad and full, the thighs plump and sinewy, the muscle extended large and hard well down to the hock. The neck is rarely very long, and sometimes hardly as long as we should like to see it, though many excellent judges disagree with us in this respect, claiming that the neck being barely long enough to make the animal pleasant in hand, not another ounce should be added, because it is only an unnecessary weight that must be carried, without contributing anything towards the power of motion.

To a certain extent this is undoubtedly true, but we place so high an cstimate upon a good and sensitive mouth, that we should prefer to have the neck a trifle too long, rather than have the animal heary in hand. Still it must be admitted that heaviness in hand is a very rare fault with this class of horses.

However horsemen may differ as to the perfection or imperfection of the neck, there can be no sort of question as to the head, which can be found as fine and beautiful in no other breed of horses except the 
thorough-bred or Arabian. Some difference of opinion exists among horsemen as to the size of the head, but we think it is now the generally received opinion that the head should be small, and all agree that it should be lean below the jowls. The first injunction given to the purchasers of horses for the French cavalry, is to "see if he has a small head," while Mr. Hinds commences the "Englishman's long-accepted description of a good horse, and nothing else," thus: "His head ought to be lean, of good size, and long."

The Morgan has a small, lean head, broad between the eyes, which are prominent, bold, lively and pleasant, full of spirit and courage, yet mild, giving evidence of a temper at once spirited and tractable. The ears are small and well shaped, set rather wide apart, but are delicate and lively.

The back is short and broad, the hips well coupled, the loins wide, and displaying on each side masses of firm, unyielding muscle, which will satisfy the horseman of his ability to carry weight and endure fatigue. Just behind the withers the back is often a little depressed, and individuals are occasionally met with, in which the depression is sufficient to warrant their being called hollow or sway-backed. This must, by no means be considered a characteristic, many families being entirely free from it, and where it is found it is usually very slight.

Where the back is very hollow we think it decidedly objectionable; but for many purposes we think a slight inclination to sway-back may be no disadvantage, especially where the loins are good. Youatt evidently considers it a far less serious objection than a tendency 
to the opposite formation or "roach-back." This inclination to hollow back, where it occurs, is so slight, and is so far from being a characteristic of the family, that it would hardly be deserving of notice were it not for the fact that it has been sometimes magnified into a universal, and of course, hereditary defect.

The origin of this mistaken notion may be easily discovered. These horses have been bred in a portion of the country that, until within the last few years, was little visited by travellers, and they were little known to horsemen abroad, except by reports of persons who had visited the country, and seen the ancestors of the family. All the early stallions of the breed lived to a great age, and it was not until their youth was passed, and a mumerous progeny had borne testimony to their excellence, that they became objects of interest to visitoris from abroad. These horses, no doubt, exhibited at an advanced age an appearance of "hollow-back," ancl due allowance was not often made for the advanced age of the animal; for although well known to most breeders, it is a fact not equally patent to a large proportion of those who have a good eye and taste for a fine horse, that old stallions are almost always defective in this respect. The loins and back of the horse, as of the dog, are the first points to show signs of failing in his old age. Another objection that may in some instances be properly urged against individual members of this breed, has, by interested persons, been magnified into a characteristic trait, and that is that they are too low on the withers. This is so far from being the fact that the opposite is the usual formation in this breed, and the great rise of the withers 
and crest, is certainly one of the striking points of the horse at first glance, but the withers are not always as thin as we should like. High, thin, fine shaped withers, is one of the rarest excellencies in the horse, and no breed or family can justly lay claim to anything like universal excellence in this particular. The reason for this may perhaps be found in the fact, that less attention is paid by breeders to this point, as it is far less important than many others. Though excellence in this point undoubtedly assists to give the horse easy and safe action, yet the race-horse is very often defective in this respect. Eclipse was remarkable for his extremely low shoulders, and many other horses distinguished for their performances on the turf, have exhibited the same defect. The mane and tail of Morgan horses are sometimes heavy, and often curly, but in most cases they are only moderately so. The general color of these horses has been much mistaken by those who are but slightly acquainted with them. It has often been supposed, and is by many believed to this day, that all genuine Morgans are bay, with black legs, manes, and tails. So far is this from being true, that it is extremely doubtful if bay be the prevailing color, chestnut being, we believe, quite as often met with.

Bay, chestnut, brown and black, are almost the only colors, the latter being quite uncommon, and with few exceptions, confined to the Black Hawk family. Gray or buckskin is very rarely seen, and is a pretty sure indication that what Morgan blood the animal has, has been derived through only one branch of the parent stock.

The average height of Morgan horses may be stated 
at from fourteen, to fifteen and a half hands. There aro a few that will fall below fourteen hands, but the num. ber is very small, and there are also some that will exceed fifteen and a half hands, but it is by no means common, and in such cases it will generally be found, that the animal has but a small amount of Morgan blood. T'heir weight may be stated to range from nine hundred, to eleven hundred pounds, the usual weight being about one thousand; any great deviation from this weight should induce the suspicion of a large infusion of other blood, although exceptions may, and doubtless do occur, in the case of animals that can show a good pedigree; still they must be considered as the exceptions to the rule, and not the rule itself. The hair of the Morgan is almost invariably fine and soft, though in some instances a little long. In the fineness and softness of their coats, they resemble the thorough-bred, though it is generally thicker.

In describing the temper, and style of action of these horses, we can say but little more than that they come fully up to our standard in this respect, with this exception, that they may sometimes have more fire and impetuosity, than we think is desirable in the "business horse," but such generally make very superior roadsters under proper management and good driving.

These horses having now been scattered a good deal in the Northern and Western States, fair specimens of the race may generally be seen at any of the State agricultural fairs, and the truth of our remarks can be verified so far as they relate to form, and style of moving. Much may also be cletermined on seeing them, as to their temper, and "lastingness;" but as it requires 
more than a short examination to determine conclusively an animal's temper, courage and endurance, and as there are many who will have no opportunity of seeing specimens of the breed, we will not leave the truth of our remarks to depend upon our own "dictum," but will introduce some evidence in support of our positions, consisting of extracts from writers whose authority upon this subject cannot be called in question. This is rendered the more necessary from the account of "Morgan Horses," published in a late edition of Youatt, to which is prefixed an account of the breeds of horses in the United States, by II. S. Randall. With this account there is published a very fair likeness of "General Gifford," as a representative of the race. The figure of the General Gifford, we admit, is a fair representative of the race, though equalled, if not excelled, by many others. As what the compiler says is very short, we extract it in full:

"Of this celebrated American variety or family of horses, the writer of this possesses little knowledge de. rived from personal experience. That they have obtained much celebrity as light buggy and sadlle horses,attracted much notice and admiration at the New York State Fairs from their remarkably spirited action and evident docility, - sold for high prices, not only for the saddle and buggy, but as stallions to extend the breed,is certain. They have many warm admirers, and find ready purchasers. Others, on the contrary, are disposed to concede to them no uncommon value as a family, as will be seen by some quotations which we shall presently make." Then follows a letter from Burlington, Vt., relative to the origin of the Morgan 
horse, without a single word as to his value, or good qualities, the sole object of the writer being to give an account of his origin. The compiler then gives an extract from the Report of the Committee of the New York State Agricultural Fair, held at Auburn in 1846, in which they say of the two stallions there exhibited, one being the General Gifford, and the other his sire, the Gifford Morgan: "Their action attracted the marked admiration of all. This breed are reported to possess great bottom and hardiness, and everything about the two presented, goes to prove that their reputation in this particular is well founded." Then follows a letter which the compiler says is from "a distinguished judge of horses in Vermont." In view of the extraordinary character of this letter, we extract it entire :

"The original Morgan ought not to be pronounced a thorough-bred horse, not having been bred from a full blood mare. Yet it is evident that the rich, high blood from which he sprung, though slightly diluted, is the cause of the reputation to which his stock has attained. But when we trace down his stock, we find in the very first generation an admixture of cold, worthless blood, to the full measure of one half. The result usual in such cases is found here. Many of the colts related more or less nearly to the old horse, exhibit the characteristics of the Morgan form, but lack compactness, not of general form, but of muscle, and they lack bottom. The general characteristics of the Morgan family are, small size, weighing from seven hundred to one thousand pounds; a long, but strong back; plumpness of general contour, like a Berkshire pig; short, hairy legs; a brusque air, a bustling gait, with more pucker 
and gather, than freedom and elasticity of step; long, coarse hair; heavy mane and tail, and a surprising disposition to accumulate fat instead of muscle, and a remarkably docile and tractible temper. As a general thing, the 'Morgans' have not length of stride enough to be good roadsters. They take too many steps in a mile. It is but very rarely one can be found thas proves to be a good all-day horse. It often occurs that one can be driven ten miles within the hour, and perhaps at the same rate for the second hour, without apparent distress or injury. But for a high rate of speed, throughout the day, search must be made among other families than the 'Morgan.' There is a place for them, however. They are good for an hour's drive for short stages. They are good to run about town with. They are good in the light pleasure-wagon-prompt, lively (not spirited), and 'trappy.' 'There is no ques. tion among those who have had fair opportunities of comparing the 'Morgans' with horses of purer blood, and descended from different stocks, in regard to the relative position of the 'Morgan.' He is; as he exists at the present day, inferior in size, speed and bottom-. in fact in all those qualities necessary to the perform. ance of 'great deeds' on the road or the farm, to the descendants of Messenger, Duroc, imp. Ifagnum Bonum, and many other horses of deserved celebrity. Thy Gifford Morgan embodies the characteristics of the Morgan form, or did emboly them, better and in more prominent and pleasant relief than any horse. I am acquainted with, of this family. ****"

We are at some loss to determine exactly the motives of the writer of this letter, in admitting that the origi. 


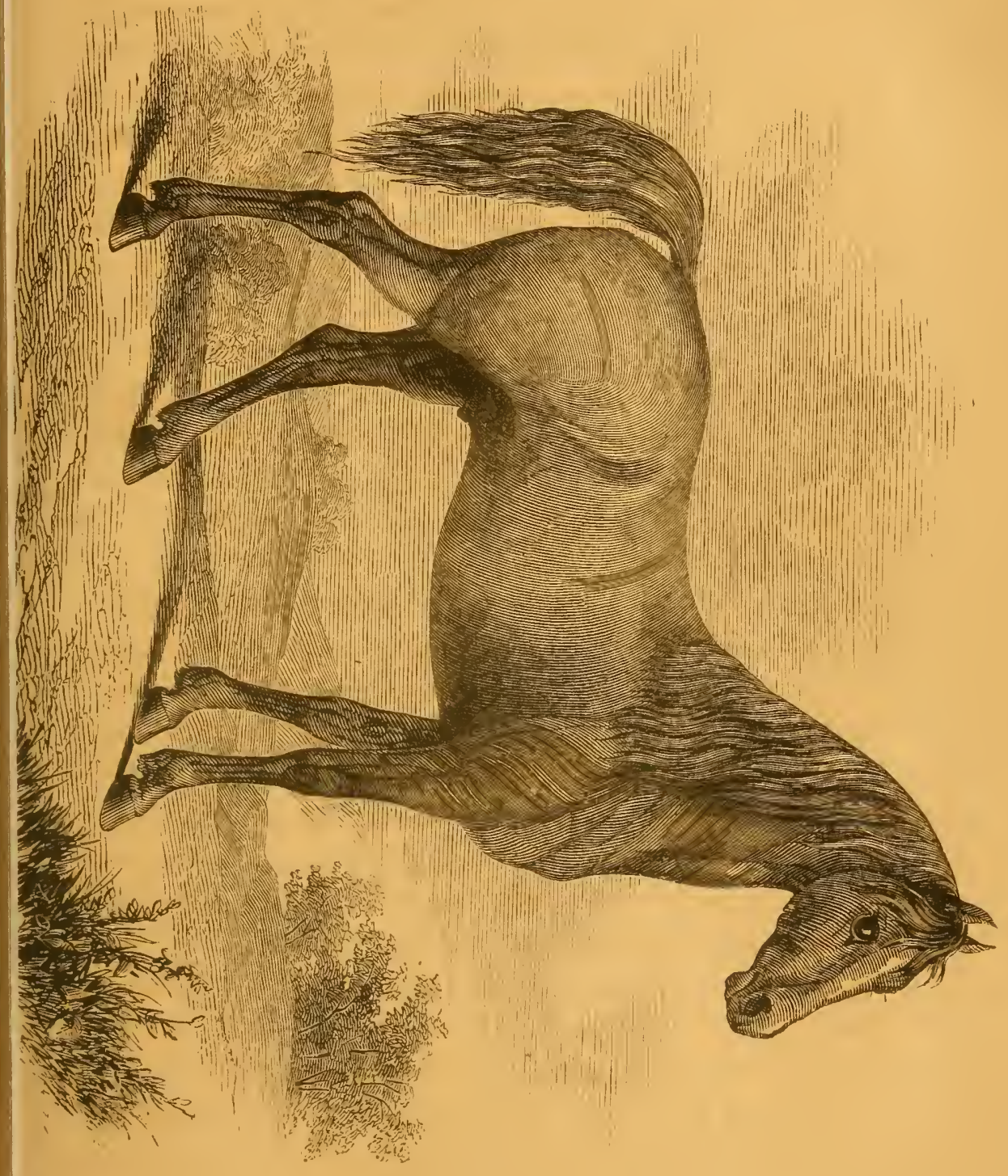



nal Morgan horse was nearly thorough-bred. He either thought it impossible to deny it, or, having adopted the theory that no horse can possess any really valuable qualities for farm or road service unless closeIy allied to the English race-horse, it was indispensably necessary to admit him to have been nearly thoroughbred, in order to sustain his theory; for he felt that it was folly to attempt to deny that his immediate de. scendants were possessed of many excellent qualities.

Having assumed that the good qualities of the Morgan all came from the racing blood he supposes he had in his veins, he is obliged to depreciate his descendants, as the racing blood disappears in his stock. He says: "When we trace down his stock, we find in the very next generation an admixture of cold, worthless blood, to the full measure of one-halt." According to this writer, all blood is cold and worthless, except it comes from the English thorough-bred, and he is evidently one of that small class of horsemen who adulate "high blood," and rejoice in the faith that the English race-horse has reached the acme of perfection for every variety of service-that he is the Alpha and Omega of all excellence in the entire genus, and who implicitly believe that he is bound to over-run the earth, as the waters do the sea, to the utter and complete extinction of all the other members of the horse family-from the Lincolnshire draft-horse to the Shetland pony.

But let us come a little nearer to the subject, and give this letter some further attention; for having been admitted by the compiler into Youatt, a standard English work, it derives from its connection a credit and authority, that would not otherwise attach to it. The 
writer says: "Many of the colts, related more or less nearly to the old horse, exhibit the characteristics of the 'Morgan' form, but lack compactness-not of gene. ral form, but of muscle - and they lack bottom." It is very satisfactory to know from so intelligent and disinterested a horseman, that the Morgan horse still preserves the characteristics of the Morgan form, and that, though he lacks compactness, it is not of form, but of muscle.

According to this writer, on the outside all is still right with this breed of horses. No fault is found with the size, or shape of the muscles; but they have an invisible defect-" they lack compactness of muscle." We think the great and striking muscular development of the Morgan horse, giving him such unrivalled ease and vigor of motion, may be safely trusted to live down this invisible defect of this invisible writer. But, he says, "they lack bottom."

Not a word of proof is offered, and the assertion leads one to think that the writer is neither a horseman nor a Vermonter, and that he has only borrowed the namc of our little State, to have a good place to write from about Morgan horses.

The unrivalled endurance of the Morgan is so universally admitted, not only in Vermont, but through. out New England, that it is desirable in charity to conclude, that Mr. Randall's "distinguished judge of horses" was not much acquainted with the animals he was attempting to describe.

Again, he says their weight is from seven hundred to one thousand pounds.

This is evidently an under-estimate, and leads any one well acquainted with the breed, to doubt the fairness 
and candor of the writer. The fair average weight of the Morgan horse, as now, and for a long time bred in Vermont, we think will prove to be, as we have already stated it, from nine hundred to eleven hundred pounds. Many breeders will think this estimate too low; but we intend to go under rather than over the weight. A few will weigh less than nine hundred, and some will weigh more than eleven hundred pounds. Let any one look at the list of Morgan horses exhibited at the last United States Agricultural Fair; the weights of a large number of them are given, and it appears that their medium size cannot be less than from nine hun: dred-to ten hundred and fifty pounds.

The next assertion of this writer is much more remarkable; he says of the Morgans, they have "a long but strong back." One cannot but fear that, before writing this, this " distinguished judge of horses in Vermont" had been looking through some deceptive glasses. One of the marked and striking characteristics of Morgan horses is, and always has been, the shortness of their backs.

Let any horseman look at the plates in this volume, or at any of the numerous cuts published in various forms, and see how near this writer has come to a fair description of these horses. Again, he says: "As a general thing, the 'Morgans' have not length of stride enough to be good roadsters. They take too many steps in a mile." Now, it is because they take more steps in a mile than the long-strided horse, that the Morgans so easily leave them behind before night-fall. It will take a long time for this writer, or any other, to 
convince the horsemen of Vermont that a long-stepping animal is the thing for an "all-day horse."

But, as the "distinguished judge of horses in Ver. mont" may not think much of New England opinions, we refer to Youatt, who, in speaking of the comparative advantages of a long or short-strided horse under the most trying circumstances, namely, in going over soft ground and over hills, says: "The compact, shortstrided horse will almost skim the surface, while the feet of the longer-reached animal will sink deep, and he will wear himself out in his efforts to disengage himself. $* * *$ Every horseman knows how much more enduring is a short-bodied horse in climbing hills, though, perhaps, not quite so much in descending them." At the present day, a long strided horse can hardly be sold for a driving horse, in the Boston or New York markets. Short steps come from short legs, and short legs are indispensable to the greatest endurance.

Let us compare for a moment this assertion, that "they have not length of stride enough to be good roadsters," with what he says in the second sentence following. Here he admits that they can often be driven twenty miles in two hours, without apparent distress or injury. Where is there a horseman but must at once admit, that the horse which can be driven twenty miles in two hours, without distress or injury, has abundance of stride for endurance throughout the day! and it is evident that, for a short distance, he must have far greater speed-for no horse can be driven at the top of his speed for two hours without. distress. 
We think the.simple fact that a horse can make his twenty miles in two hours without distress, will, by most horsemen, be deemed the strongest possible evidence (save actual trial) of his ability to perform more than an ordinary day's journey.

The compiler, at the close of this long attack on Morgan horses, from a concealed enemy, says of it: "The above is not, as already stated, the popular estimate of this family. Having stated both sides of the question, we leave it to the judgment of the public." What does the compiler mean by "having given both sides"? The only thing the compiler gives favorable to the Morgan is from a Ner York Committee, who were evidently strangers to the breed, and whose opinion was based on the two specimens before them. The Morgans were among strangers, where they and their owners were unknown. They were judged by a New York Committee, and New York had then but little interest in the Morgan breed of horses, and they were, of course, surrounded by friends and acquaintances interestod in other breeds. But they were too accomplished horsemen to overlook the cxtraordinary characteristics of the Morgans, and too frank and manly not to speak out fully and boldly their opinions.

What they have said is the verdict of a New York jury. Aside from that verdict, the compiler has admittod nothing in favor of tho Morgan horse; and this is what he calls "giving both sides."

The reputation of this breed of horses is not the result of a temporary excitement, got up by interested parties to assist their sale, but it is the result of a long and convincing trial of their powers. The attention 
of horsemen was drawn to them long ago, and their reputation has gone on increasing steadily from that day to the present.

The following extracts are from a letter written by a gentleman of Philadelphia to the American Turf Register and Sporting Magazine, in 1831.

"*** It may not be generally known that the first trotting matches in this country took place in New England; and twenty years ago, every stranger who travelled the road from Boston to Portland, a clistance then of one hundred and twenty miles, must have been surprised to see horses, not quite fifteen hands ligh, drawing heavy carriages, with nine passengers, at the rate of eight and ten miles an hour, accomplishing the journey with ease in one day. **** From what is known of the speed and strength of this horse, and his properties, so well adapted for the road as well as the turf, it has always seemed unaccountable to me why farmers and breeders generally do not introduce the trotting horse instead of the high-mettled racer, of whose usefulness scarcely one word can be said. I am, however, far from underrating the thorough-bred horse: the sports of the turf are always interesting to me; but I now address practical men, and I ask, if they would not benefit thcmselves and the community more by raising the trotter instead of the racer?

"The one is useful as a work-horse on the farm or on the road; generally kind and gentle in harness, and often active enough for the saddle. Whilst the other, if his strain is superior, has an irritability, a nervousness, that unfits him for the steady routine of making wheels turn round, and is only calculated to carry a 
light weight and occasionally win a plate or purse. I believe it is estimated that only one colt in thirty proves himself a first-rate runner, under the most judicious management in the selection of brood mares, and the greatest care in feeding, grooming and bitting. Such a colt may possibly bring two or three thousand dollars, but the twenty-nine may not average one hundred and fifty dollars; while the trotting colt of good prom ise (which is indicated not unfrequently at three years old,) readily brings from two to five hundred dollars, and some of them one thousand. Besides, these horses are always in demand; every man in the neighborhood of our large cities, travelling on dusty roads, wants a trotter for his every-day use; but how few of them keep a racer?

"I am aware that fine roadsters are sometimes obtained by crossing the large common mare with the fullblooded horse. There are instances of it in the progeny of old Messenger; he was the sire of Fagdown, and, I believe, of Mambrino and Hamiltonian ; and this stock has supplied Philadelphia and New York with the only trotting horses that they raised for some time. Tippoo Saib, who now stands at the Hunting Park Course, belongs to the same family; and although, as a trotter, I have never heard of his performance, yet he is the sire of Lady Miller, a very celebrated trotter.

"Now, with the exception of Messenger, I have never been able to trace extraordinary trotting families derived from such a source. There are individuals of celebrity whose origin is unknown; but we want, in this quarter, the distinct race, as they pervade some parts of the Eastern States, and the county of Norfolk, England. * * 
"I think there are two reasons why we have not supplied the Philadelphia market with the right kind of roadster; one is, we have mixed up too much of the running stock, particularly in New Jersey and Southward of us; and the other is, we have too litlie. "That medium so desirable for the road, which for years has given celerity to the private and public conveyances in New England, was not generally known here until the establishment of the Trotting Club on the Hunting Park Course."

In the March number of the Albany Cultivator for 1848, J. B. Burnett, a "thorough-bred" man, in an article in favor of thorough-bred horses, and against the Morgans, with equal truth and candor says: "It cannot be denied that they possess great energy and courage, great strength and endurance, great ambition and docility; that they mature early and are easily kept; that they are pleasant drivers and always ready for business, and-what is more important-sell at high prices."

R. L. Allen, Esq., an accomplished gentleman in New York, and a thorough horseman, having no interest then or since in MIorgan stock, so far as we can ascertain, thus speaks of them in his American Agriculture. After pointing out their origin, he says:

"The result has been the production of a family of roadsters of much similarity of appearance and uniformity of character, unsurpassed by any others for serviceable qualities. They are of medium size, from thirteen and a half to fifteen hands high, with a wellformed head and neck, high withers, deep chest, round body, short back, large quarters, broad, flát legs, mod- 
erately small feet, long, wavy mane and tail, presenting altogether the beau ideal of the road horse.

"They are spirited and docile, hardy and easily kept. They have an easy and rapid trot, and glide along with a good load without clatter or apparent effort, at the rate of ten or twelve miles an hour."

Mr. Weissinger, formerly one of the editors of the Louisvitle (Kentucky) Journal, tnat has for many years been a leading paper at the South, made a tour through the Northern States in the summer of 1845 . While in Vermont, his taste for horses prompted him to examine carefully the Morgans. In a letter to the "Journal," after some remarks in relation to their origin, he says:

"There is no doubt whatever of this-that the breed of the Morgan horse was, and is now, in the few in. stances where it can be found, far the best breed of horses for general use that ever was in the United States-probably the best in the world; and it is remarkable that this breed was, and is now, known by many striking peculiarities, common to nearly every individual. They have a full, heavy, wavy mane and tail, good head and neck, small, well-shaped ears; are broad between the eyes; legs broad and short, with large tendons, bodies rather thick-set; but their most striking peculiarity is in their carriage: legs well under, trot quick, short and springy, the fore-legs bending remarkably, the rery reverse of the slow, slouchy movement of the race-horse in the trot. They are likewise exceedingly hardy and well-tempered."

In the American Farmer's Encyclopedia, edited by 
Governeur Emerson, and published in Philadelphia, in 1844, is the following description of the Morgan horse: "Perhaps the very finest brecd of horses in the United States, when general usefulness is taken into consideration, is what is commonly known in the North ern and Eastern States as the Morgan horse.

"This breed is distinguished by its activity, united with strength and hardiness. Its size is moderate, and though not often possessing the fleetness which recommends it to the sportsman, it has speed enough to entitle it to the appellation of a fast traveller. Their usual height is from fourteen to fifteen hands, color bay, make round. and rather heavy, with lean heads, broad and deep chests, the fore limbs set wide apart, legs clean and sinewy, short, strong backs, with that projection of the ribs from the backbone which is a sure indication of great development of lungs, and consequently of great wind and bottom. For saddle, draught, and other useful purposes, the Morgan horses, bred in Vermont and in all the Eastern States, including the Northern and Western parts of New York, are so much prized as to command much higher prices in the principal cities of the Atlantic States, than horses from other parts of the Union."

The Maine Farmer for 1853 (we think in the April number) in an editorial, thus speaks of the Morgan horses: "The stock of Morgan horses is so univer sally known and admired throughout New England, that it is hardly necessary to repeat their merits. For a seller of horses, it is only necessary to establish the fact that his horses are of the Morgan blood, and he 
meets with a ready sale at good prices, and tho purshasers are more than satisfied.

"They excel in great endurance, carrying weight a long distance; and as roadsters they excel all other horses in this or any other country; are full of noble and generous spirit, with such docility of temper that the most timid can drive them; but if put to their metthe, they are a full hand for the best driver." In an elaborate article in the New York Hercld, in relation to the horses of that city, published early in 1853 , in speaking of the large number of horses cmployed in hauling the cars on the Sixth Avenue Railroad, the writer says: "Four-fifths of all the horses employed on this road are from Vermont and New IIampshire, and of these neary all are of the celebrated Morgan breed. 'These horses have long and justly been celebrated for their admirable qualities as roadsters.

"They are particularly remarkable for their great strength in proportion to their size, and for their power of endurance, bearing up under hard labor that would break down the strongest draft horse.

"The Morgan horse, though a small animal, is noted for his great bottom and hardiness, as well as for compactness and roundness of form. He is a very sprightly animal, and is said to be more sagacious than the generality of horses."

By reference to the report of the United States Agricultural Society's Fair, held in Boston, Mass., the fourth week in October, 1855, it appears that three premiums were offered to stallions as "roalsters;" of these all were awarded to stallions of Morgan descent; four premiums were offered to stallions for general use, four 
years old and upwards. All of these were awarded to Morgans. To stallions for general use, three years old and under four years, two premiums were offered; one of these was awarded to a Morgan. To stallions for general use, one year old and under two, three premiums offered; two awarded to Morgans. To breeding mares and fillies four premiums were offered; two awarded to Morgans. To fillies three years old, two premiums offered; one awarded to a Morgan. Fillies one year old, only one premium awarded, and that to a Morgan. To trotting stallions four premiums were offered, and three of them awarded to Morgans.

That this was a very large exhibition of horses is certain, for there were four hundred and forty-three horses entered for premiums. The report of every State Fair at the North and West, shows that wherever exhibited, the Morgans take the very highest rank as horses for general use. Now this evidence of his value is the more striking, as at most of these agricultural exhibitions he is among strangers, and he comes into competition with horses long known and having many friends around to assist in sustaining them. A horse that can compete successfully for the highest honors under such circumstances, must be so plainly, and so far superior to his rivals, that the moment he is seen the spectator acknowledges, without hesitation, his great superiority. The appearance of "Champion Black Hawk," and Silas Hale's "Green Mountain," on the fair grounds of Kentucky, at difierent times, strikingly illustrate this.

In the account of the agricultural fair, at Florence, Kentucky, in October, 1855, published in the Cincin nati Gazette of October 13th, 1855, is the follow- 
ing description of the exhibition of stallions for har. ness :

"The Fair at Florence.-Yesterday was the day for the exhibition of horses. In the ring of stallions for harness, of four years old and upwards, the blue ribbon (highest premium) was tied on a dapple grey, but just then Champion Black Hawk, belonging to Messrs. P. \& L. Melendy, of Hamilton County, Ohio, was brought in, and the multitude immediately shouted, 'take it off,' 'take it off.'

"It was accordingly taken off and put upon Black Hawk, and no judgment of the Committee was more heartily approved by the spectators than this. Champion Black Hawk is of the Morgan stock, and closely resembles old Green Mountain Morgan in size, build, and carriage. He is a small horse, but compactly built, indicates power and endurance, and in horseman phrase is "big for his size." "

So, also, when Hale's Green Mountain appeared on the show grounds at Louisville, Kentucky, in 1853, he met with a cordial welcome, and the horse was greeted on his entering the exhibition ring, with such eager applause as told, full plainly, that his form and his style of action were new, but were appreciated by the thousands of strangers before whom he was moving. It is hardly necessary to say that he received the highest premium, as he had previously done the same season at the Michigan State Fair at Detroit, and the Ohio State Fair at Dayton.

It is proper to add, that the horse was taken from Vermont to Dayton, Ohio, by railroad, without any stop for the purpose of rest. The fair at Dayton being 
over, he went directly to Detroit, arriving there after the commencement of the fair. From Detroit he went directly to Louisville, where he arrived late the night previous to the last day of the fair.

The following letter is from a gentleman long engaged in staging, whose opportunities for observation have been very extensive, and we would as soon rely upon his judgment in anything relating to the qualities of a good horse, as that of any person we have ever met:

"Jefferson City, Missouri, April 14, 1856.

"D. C. Linsley, Esq.

"Dear Sir:- It is with much pleasure I have to acknowledge the receipt of your favor of a recent date, requesting me to give you my views of Morgan horses, as compared with horses in general use at the West.

"I have spent the greatest portion of my life in staging, formerly in Vermont, and now in Missoururi, and I take pleasure in bearing testimony to the decided superiority of Morgan horses for coach service, over any others that I have ever used. I have bought many horses in Ohio, Kentucky, Indiana, Illinois, and Missouri, and though occasionally a good roadster can be found, they are not common. Many of the horses of these States have fine forms and good carriage, yet lack the high, free spirit, unflinching courage, and iron constitutions the Vermont horses so generally possess. Very many of the Western horses are too large. Large horses may be the best for draft, but I have always found horses of medium size, weighing, say about ten hundred and 


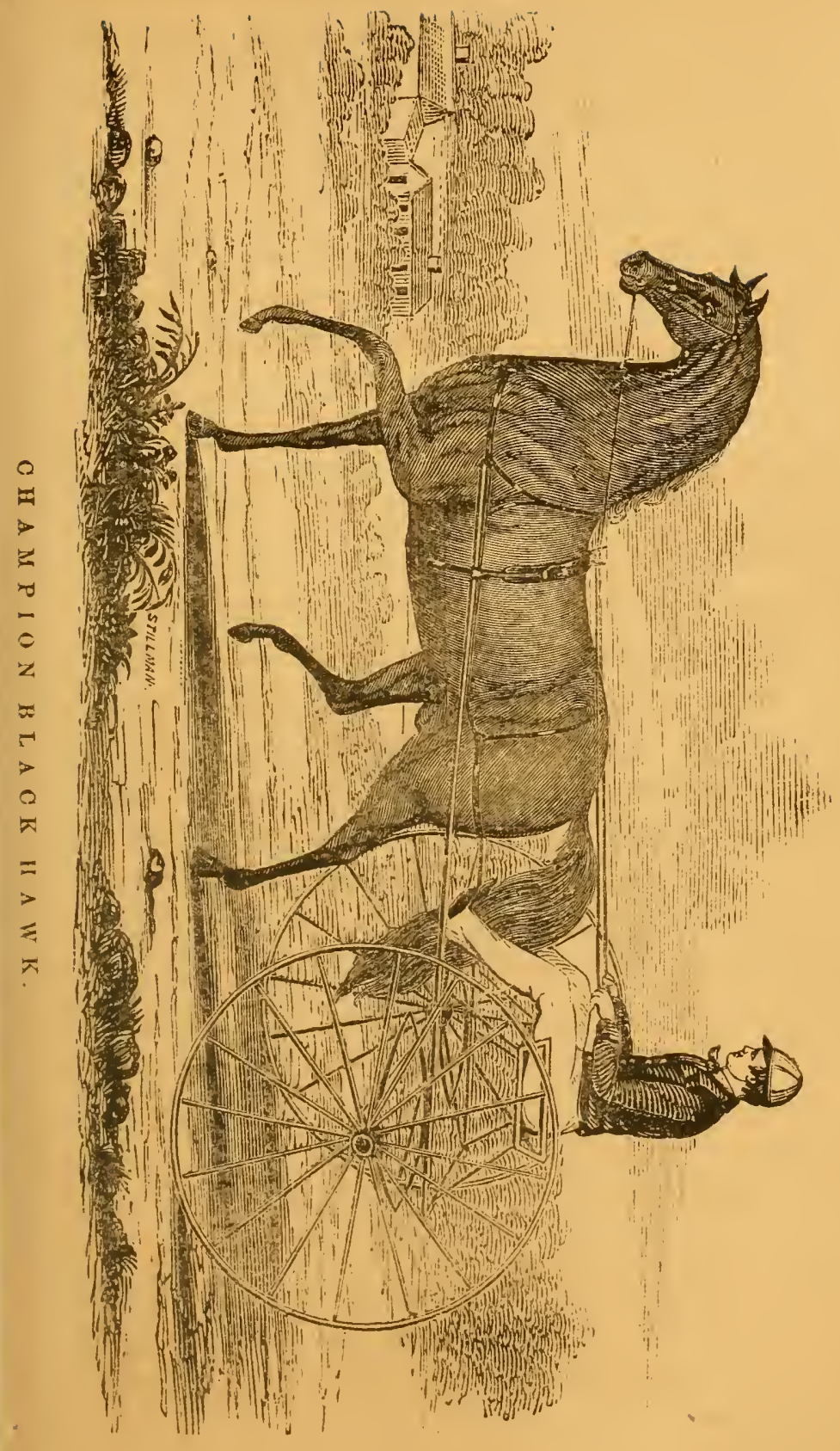



fifty pounds, much the most serviceable and enduring when used before a coach.

"I am, Sir, very respectfully yours,

"MILO JUNE."

The writer of the following letter is well known at the East, and throughout the West, as one of the largest and most successful stage-owners in our country, and the noble fortune he has secured, by his own exertions, sufficiently attest his practical wisdom, and the soundness and solidity of his judgment. His large experience at the West gives peculiar value to his opinion, with regard to horses, adapted to that country:

\section{"Chicago, April 21st, 1856.}

"D. C. Linsley, Esq.

"DEAR SIR:-Your favor of the 8th inst. is received, in relation to the Morgan breed of horses, and expressing your desire to make them more generally known in the Western States. This desire I sincerely share with you, and cannot doubt your entire success.

"Being a Vermonter, I have known Morgan horses as long as I have known any. I have resided at Chicago the last seventeen years, during which time I have been largely engaged in the business of stagingwhich business affords constant employment for about fifteen hundred horses-and have thus had opportunities for observing and testing the capacity and endurance of horses. I have no besitation in saying, I consider the Morgan horses far superior to any other breed or blood I have ever known for the road or farm.

"In fact, I would prefer them over all others for 
any kind of service on the American Continent. They are invariably good feeders, are easily kept, and will not only perform and endure more service in a year, but more years of service, than any other breed of horses I have ever known.

"Of the horses heretofore raised in the Western States, and particularly West of the Lakes (although much improvement has been made within a few years, and many fine horses may now be found among them), it is undeniably true, that a Morgan horse, from New England, will outlast two horses raised in the West.

"It is also true, that but few Morgan liorses have, as yet, been brought from New England West of the Lakes, and equally true, that their services are very generally sought by intelligent breeders of horses throughout the country. Any number of inferior horses may be found in the West, which are claimed to be of Morgan blood.

"This attempt to palm off counterfeits, is the highest evidence of the value of the genuine blood. The ready and general objection in the West, with those who are not familiar with the Morgans, is want of size, forgetting that their size should be judged by their weight, and not by the length of their legs, and that the same bodies, upon longer legs, would look much larger. Wishing you success, and hoping that you may be instrumental in causing the whole of our fine State to be filled with horses of pure Norgan blood,

"I am, Sir, your friend and servant, "M. O. WALKER."

We might continue to adduce testimony of a similar 
character to almost any extent, but we think the foregoing extracts from the highest sources, from persons uninterested in these horses, and residing in quarters of the country where they have not been bred, amply sufficient to establish the fact, that the Morgans, as a race, are possessed of great powers of endurance, and are admirably adapted for the road and general use.

From a consideration of the foregoing extracts, it is to be hoped, that "a distinguished judge of horses in Vermont," will review his opinions, and that the accomplished compiler of the breeds of horses in the United States, will not admit into a future edition of so valuable a work as Youatt's, an article so prejudiced, and so untrue. 


\section{CHAPTER $\nabla$.}

ORIGIN OF THE MORGAN HORSE.

THE different accounts that have been circulated in regard to the origin of the Morgan breed of horses, agree that they are descended from a horse called the Justin Morgan, who derived his name from Mr. Justin Morgan, of Randolph, Vt., once his owner. As to the origin of the Justin Morgan, however, they differ widely.

The fact that little or no interest was felt in the sub. ject until after the death of Mr. Morgan, and indeed until after the death of his horse, will account for this diversity.

Almost half a century passed away before any serious effort was made to determine the origin of an animal, whose value was daily more and more appreciated. After the death of Mr. Morgan the horse passed through several hands, and was kept at different places, and when at length serious inquiry was awakened on the subject, it was found that Mr. Morgan had left no writtén pedigree of his horse, and different reports of what he said in relation to it got into circu. lation.

We think it may be considered as certain, that during Mr. Morgan's life and until long after his death, very little interest was felt in the question, "What was the 
exact pedigree of the horse?" When the inquiry became interesting, and discussion arose, different stories were current, and opinions were frequently formed in accordance with previous prejudices or views of the individual forming them, as to the value of different breeds of horses. Some, holding the opinion that no valuable horse could be expected without a great deal of racing blood, sought to make it appear that he was nearly thorough-bred. Others having less faith in the English racer, entertained different opinions, and adopted for their creed stories that ascribed to him a very different origin. No person seemed to take the matter in hand and investigate it thoroughly, until those who might have given the necessary information were gone. It is not now probable that the blood of the Justin Morgan can ever be exactly and absolutely ascertained. We think, however, it may be considered certain that this unrivalled animal was produced by a cross of the Arabian or thorough-bred with the common stock, but the proportion of each cannot now be determined.

There are no opinions that men maintain so strenuously, and give up so reluctantly, as those which they form and publicly avow upon matters in which they are supposed by others to be particularly well-in. formed. This is more especially true when these opinions entertained and expressed, relate to matters of practical importance, and not simply to some abstract doctrine.

Thus, suppose a man has studied long upon the subject of rotation of crops, and is thought to understand it thoroughly; if his neighbor acting upon his advice is thereby injured, he will account for the fail- 
ure in any way, rather than ascribe it to his own want of information, or error of judgment.

So the tradesman much more reluctantly acknowledges an error of judgment in relation to an article of which his very trade presupposes him to be a judge, than the man whose attention has been but momentarily drawn to it. It is to this disinclination to admit they have been in error, coupled with inattention to the proofs that have been offered, that we mainly attribute the disparity which may be noticed in the accounts given by horsemen of the origin of the Morgan horse; for we think all candid persons who will devote but a little time to an examination of the subject, can hardly fail to arrive at one and the same conclusion. So much importance has of late years been attached to this subject, and some excellent horsemen not fully agreeing in relation to it, we have been led to devote a good deal of time and labor to a careful examination of all such evidence as we could discover, and the result of our investigation is (as before stated) the firm conviction that the original Morgan horse was not thoroughbred, but yet, had a large infusion of blood.

Before considering the evidence that has led us to this conclusion, we wish to explain what seems to us should be the character of the evidence that should be deemed amply sufficient to establish this point.

While the friends of these horses have been sometimes ready to declare the original Justin Morgan fully thorough-bred, on the strength of evidence which we think can hardly be deemed sufficient; yet on the other hand, parties interested in denying he had any claim, even to a particle of that noble blood, insist upon proof that shall amount to demonstration. 
The pedigree of a stock horse may in one sense be considered property; it is a valuable thing, and one from which the owner may derive great benefit. Now what reason can be assigned for insisting that a man shall adduce stronger evidence to establish his claim to such a pedigree, than is required before a court of justice to secure him in the possession of his house, or his farm; or stronger than would be sufficient to enable his neighbor to turn him out of doors? There can be no reason. But some gentlemen insist that the pedigree of an animal, to be entitled to credit, should be supported by evidence as conclusive as would be required to send the owner to the gallows, if he were indicted for murder. This is certainly most unreasonable and unjust.

The following articles, we believe, comprise all the important statements in relation to the origin of the Morgan horse that have ever been published. Some of them have been printed in very many different papers throughout the country, but, with a single exception, we believe, they were all originally published in The Albany Cultivator.

In the October number of that paper for 1841, Vol. 8, p. 162, there appeared the following letter and accompanying affidavit:

"Messrs. Gaylord \& Tucken: I lately received great satisfaction from hearing what appears to be a correct account of the origin of the Morgan horses of Vermont; a breed known and esteemed for activity and hardiness, throughout all the Northern States; not remarkable for size, and scarcely known to the 
sportsman for speed. This race is perhaps as highly celebrated as any for general usefulness, and for such a degree of flectness as entitles it to the appellation of fast traveller.

"Their height is from fourteen to fifteen hands; color, bay; make, round and heavy, with lean heads, broad and deep chests, the fore-limbs set far apart, clean and sinewy legs, short strong backs, with that projection of the ribs from the spine which is a sure indication of powerful lungs, and, consequently, of great wind and bottom. The original Morgan horse, called also the Goss horse, is well known to have appeared in Randolph and in St. Johnsbury (Vt.) some forty years since, and to have been kept as a stallion, at first with but little, and subsequently with very great patronage, some five and twenty years, or until he was thirty years old or more. Various accounts are current as to his origin; many think it quite distinct from the Canadian breed of Norman-French extraction, and consider the horse to have been of Dutch blood, and to have been introduced from some of the settlements on Hudson river, southward of Albany. Stories are told of a traveller's blood mare having got with foal by a Canadian or Indian pony, at various places north and west, and having brought forth this horse; all these accounts are improbable, and appear to be unauthenticated.

"For the last dozen years, being aware, both by observation and experiment, of the surprising results of crossing the Canadian with other breeds of horses, and having become acquainted with the vast variety and different qualities of various races in the Canadian breed, I have believed that the original Morgan horse 
was of French Cauadian origin. This opinion being confirmed by the accounts here given, I am anxious to ascertain whether any one can prove it erroneous, and, if not, to make it public, that it may be known that thousands of horses may be obtained in French Canada of the same blood, and not inferior in qualities to the Morgan, whose existence added several hundred thousand dollars to the wealth of Vermont.

\section{"George Barnard.}

"Sherbrook, P. C., August, 1841."

\section{"(AFFIDAVIT.)}

"I was about thirteen years of age when the Morgan horse was first brought to St. Johnsbury, in Vermont, where my father lived. As I am now fifty, it must have been about 1804. On the cre of the second Tuesday in June (for I well remember that the morrow was training-day) I was at my father's house, and a man of the name of Abel Shorey, a skilful horseman of the neighborhood, was there also; when David Goss, jr., my cousin, then aged about seventeen, came up from his father's, distant about three-quarters of a mile, with a message to Shorey, requesting him to go to his father's (my uncle David's) and trim a horse that rincle John Goss had just then brought over from Randolph, distant forty miles.

"I accompanied them, and, at my uncle David's, we found uncle John from Randolph, with a little, heavy, handsome, active bay horse, which he requested Shorey to trim, chiefly by pulling out and cutting the hairs of his tail, which appeared as if it had been gnawed by calves. Uncle John said he was a Canadian horse 
that he had just got from Justin Morgan of Randolph, who had lately brought him from Montreal. I, after. wards, frequently heard the manner of his purchasing the horse related in my father's and uncle David's families, which was this: uncle John had lent Morgan the sum of forty alollars on occasion of the latter's going a journey to Montreal in Canada. Morgan obtained the horse, then four years old, at Montreal, and being unable to repay the money on his return, disposed of him to uncle John, to pay the debt. Uncle John, who was no horseman, now brought him to my uncle David, who was much of a horseman, in the hope that something might be made by kreping him for mares. I remember Shorey's calling him 'a full blood French horse.'

"Uncle John Gross engaged Shorey to take the horse next day to training, at Maj. Butler's, and there I saw him cover four mares.

"My uncle, David Goss, kept the horse through the season, working him on his farm, and putting him to mares when they were brought; he also kept him through the next winter and the ensuing spring, when the foals were found to be universally excellent; uncle John took him back to Randolph, where he made his socond season: the third season he was brought to St. Johnsbury, and stood at uncle David's again. After this, as I went to learn my trade, I cannot give so particular an account of the horse, but remember that he was kept several seasons in St. Johnsbury.

"This, and more to the same purpose, may be attested by David Goss, sen., Phillip Goss, David Goss, jr., 
Clark Stearns, Abel Shorey, Abel Butler, and Thomas Pierce, all of St. Johnsbury.

\section{"John Stearns.}

"Sworn before me at Charleston village, this 14th of August, 1841.

$$
\text { "David Connell, J. P." }
$$

In the June number of "The Cultivator" (Vol. IX., p. 99), is the following letter:

"Messrs Gaylord and Tucker:-Mr. Edward Terry, of Rochester, $V$ t., recently sent me two numbers of your 'Cultivator,' containing some account of the origin of the Morgan breed of horses, and also an affidavit of John Stearns, of St. Johnsbury, Vt., relative to the same subject. I have read the affidavit of the said Stearns attentively, and lnow that he is entirely mistaken in all his statements relative to the time said horse was brought into Vermont, the place from which he was brought, and the manner in which he says his uncle, John Goss, obtained said horse of my father. I know very well that Mr. Joln Goss never obtained said horse of my father in any way whatever. $\mathrm{My}$ father owned said horse to the day of his death, and, in the settlement of my father's estate, said horse passed into the hands of William Rice, then living in Wood. stock, Vt., since deceased.

"I will now relate the facts relative to said Morgan horse, as I recollect them. My father, Justin Morgan, brought said horse, or, rather, said colt, into Randolph, Vt., in the summer or autumn of 1795. Said colt was only two years old when my 
father brought him to Randolph, and never had been handled in any way, not even to be led by a halter. My father went to Springfield, Mass., the place of his nativity, and the place from which he removed to Randolph, in the spring or summer of 1795, after money that was due to him at that place, as he said; and, instead of getting money as he expected, he got two colts-one a three ycars old gelding colt, which he led, the other, a two years old stud colt, which followed all the way from Springfield to Randolph; having been, as my father said, always kept with, and much attached to the colt he led. Said two years old colt was the same that has since been known all over New England by the name of the Norgan horse.

"My father broke said colt himself, and, as I have before remarked, owued and kept him to the time of his decease, which took place in March, 1798, and said horse was five years old the spring my father died; and, as before stated, soon after my father's decease, he passed from my father's estate into the passession of Wm. Rice, of Woodstock, Vt. I cannot state positively that my father purchased said colt in Springfield, Mass., but I am very confident that he purchased him in that town, or in the immediate vicinity on Connecticut river, and I know that my father always, while he lived, called him a Dutch horse.

"Stockbridge, Tt., Narch 1, 1842."

"Justix Morgan.

In the next number of "The Cultivator" (Vol. IX., p. 110), under the head of "Condensed Correspondence and Enquiries," we find the following article: 
"After our last paper went to press, containing the statement of Justin Morgan, Esq., of Stockbridge, Vt., that his father brought the original Morgan horse from Springfield, Mass., we recerved a communication from Mr. John Morgan, of Lima, in this State, confirming the statement of Justin Morgan, that the sire of the celebrated Morgan horses of Vt. came from Massachusetts, instead of from Canada, as has heretofore been supposed. Mr. John Morgan informs us that he resided in Springfield, Mass., near Mr. Justin Morgan, sen., previous to his removal to Vermont, and that the two years old stud which he took with him to Vermont, as stated in our last paper, by Mr. J. Morgan, jr., 'was sired by a horse owned by Sealy Norton, of East Hartford, Conn., called the True Briton, or Beautiful Bay; he was kept at Springfield one season, by the said Justin Morgan, and, two years after, I kept him two seasons.' This horse was said to be raised by Gen. De Lancey, commander of the refugee troops on Long Island, and rode by him in the Revolution. It was said that one Smith stole the horse from the General, at King's Bridge, while the General was in the tavern-ran him across the Bridge, and took him to the American army near White Plains, and sold him to Joseph Ward, of Hartford, Conn., for \$300. It was also said, at that time, that he was sired by the noted imported horse, called the 'Traveler,' said to bo kept in New Jersey. Ward was a merchant, and kept the horse threc or four years for a saddle and carriage horse, and traded him off to Norton, and Norton kept him for mares while he lived. The description 
of the Morgan breed, given by Mr. G. Barnard, answers well to the description of the stock of True Briton.

"His stock was all bright bays, some inclining to sorrel. I have always understood that Morgan kept the colt for a stud at Randolph, and was very celebrated for his stock."

The following extract from Mr. Weissinger's letter to "The Louisville Journal," published in the autumn of 1845 , to which we have before alluded, embodies one of the stories that have been circulated to some extent in relation to this matter.

"Mr. Cottrel, of this place, (Montpelier, Vt.,) who is as well acquainted with horses as any man in Vermont, says there is not the slightest doubt that the original Morgan was got by a Canada horse. He says the most probable account of his origin is this: 'A man by the name of Smith, of Plainfield, N. H., had a fine imported mare. He rode this mare to Canada on a courting expedition, and while there his mare got in foal. Smith regretted the accident, and laying no value upon the colt, he sold it to Morgan, a singing-master, who, when the colt was grown, rode him around on his singing circuit. When the colts from Morgan's horse grew up, they proved fine, and this gave him celebrity. He was a fleet runner at short distances, and this originally induced the people to try him.'"

In the January number of "The Albany Cultivator" for 1846, Vol. III., (new series,) page 19, is published a letter from Frederick A. Weir, of Walpole, New Hampshire, from which we extract all that in any way relates to the origin of the Morgan horse, as follows: 
"For the last fifteen years my business has called me frequently into almost all parts of Vermont, and I have been led to make very extensive and particular inquiries into the history of the Morgan horse. Although there are six or eight, or more, different stories in circulation in relation to his origin, and several of them attempted to be supported by afficlavit, yet I perfectly agree with you that the account given by Justin Morgan's son, Justin Morgan 2d, who is a merehant now in business at Stoclibridge, Vermont, and a gentleman of intelligence and standing; extended and confirmed by that of Mr. John Morgan, is the only one entitled to belief.

"From my correspondence with Justin and John Morgan, and others, I am enabled to state the pedigree on both sides of the Morgan horse.

"He was foaled in 1793, was sired by True Briton, or Beautifur Bay; owned by Sealy Norton, of East IIartford, Conn., and then kept by John Morgan at West Springficld, Mass. True Briton was sired by the imported horse Traveller.

"The dam of the Justin Morgan horse, at the time he was sired, was owned by Justin Morgan himself, at Springfield, Mass, where he then lived.

"The dam is described by Mir. John Morgan, who knew her, as of the Wild-air breed, of middling size, with a heavy chest, of a very light bay color, with a bushy mane and tril, the hair on the legs rather long, and a smooth, handsome traveller. She was sired by Diamond, a thick, heavy horse of about the middling size, with a thick, heavy mane and tale, hairy legs and a smooth traveller. Diamond was kept by Justin Mor. 
gan himself, at the time the dam of the Morgan horss was sired. He was raised in East Hartford, Connecticut. His sire was the Wild-air, known as the Church horse. His dam was the noted imported mare Wildair, owned by Capt. Samuel Burt, of Springfield, Mass. The Church horse was sired by the horse Wild-air, imported by Delancy, of Long Island, and as it was said, was afterwards taken back to England.

"Mr. John Morgan describes True Britton as being a high-headed and hollow, or sway-backed horse, and his stock of such a description; and states that the Wild-airs also, were generally so."

Under date of Stockbridge, Vt., Feb. 27, 1847, Mr. Justin Morgan writes to "The Albany Cultivator" as follows :

"There seems to be some persons who still continue to suppose that there was 'French-Canadian' blood in the original horse which belonged to my father, Justin Morgan, and from which the excellent stock of 'Morgan horses' sprung; while no one who has attended to the clear proofs to the contrary, which have from time to time appeared in your valuable Journal, can now justly entertain any such notion.

"In the fall of 1795, my father brought the horse, then a two years old colt, from Springfield, Massachusetts, to Randolph, Vermont. Mr. John Morgan, of Lima, N. Y., who, though of the same name, is but a distant relative of my father's family, then lived, as I have been informed, in Springfield, and had every opportunity, as I believe, of knowing the truth in relation to the horse. Mr. J. Morgan says he was not only well acquainted with my father's horse, but also with 
the sire of that horse, 'True Briton' or 'Beautiful Bay,' and he states that he (Mr. J. M.) kept the latter horse at the time my father's colt was begotton by him. He says, also, that he was acquainted with 'Traveller,' 'Diamond,' and 'Wild-air,' and at the time knew them to be English-blood horses. Mr. John Morgan further sars, that however much may have been said relative to my futher haring brought the horse from Canada, he knows that it was not so. His means of knowledge, and the respectability of his character, entitles his statements to the fullest credit. The fact that my father died about two and a half years after he brought the colt into Randolph, his children all being young, and the horse having been sold out of the family very soon after my father's decease, may account for his pedigree not being better understood. I have a perfect recol. lection of the horse when my father owned him and afterwards, and have always lived where his stock is well known, and well remember that my father always spoke of him as a horse of the best blood. * * * "

In order to get a clearer idea of the whole subject, let us glance at some facts in relation to Mr. Justin Morgan. He was born in 1747, at West Springfield, Mass. Iis father was not wealthy, and was able to give Justin ouly a common education. He was natrrally quick and intelligent, and by application obtained a thorough knowledge of the primary English branches, was an excellent penman, and a very fine singer. Physically he was tall, slim, and of feeble health, being inclined to consumption. In fact, he was unable to perform any manual labor of importance after he was twenty years old, and supported himself almost entire. 
ly by teaching singing, writing, and common district schools. As a teacher, he seems to have been successful, and was very much liked wherever he went, on account of his urbane manners and upright character. At about thirty he was married, and the fruit of this connexion was one son and four daughters. The son was born March 15, 1786, and was called after his father, Justin.

In the Spring of $1788 \mathrm{Mr}$. Morgan sold his place in Springfield, Mass., and removed with his family to Randolph, Vt. His wife, Martha, died March 20, 1791, and he died March 22, 1798. The most important of these facts, so far as they relate to our present subject, are first, the time at which he removed his family from Springfield, Mass., to Randolph, Vt.; and second, the time of his death; and we will here give the reasons for the statements we have just made in relation to these events.

In the Book of Record of Deeds of the county of Hampshire, Mass., No. 29, page 29, it appears that on the 12th of March, 1788, Justin Morgan sold to Abner Morgan a lot of land in West Springfield, Mass., estimated to contain about two-thirds of an acre, and upon which there was a house and barn, for the sum of thirty-three pounds seventeen shillings and sixpence. From this time until his death, there is no record of his having conveyed any other real estate in that county, nor can we find any record of any conveyance of real estate to him.

From this it is clear that he sold his property in Springfield, Mass, in the Spring of 1788. It seems equally clear, that he removed his family to Randolph the same Spring, for his daughter Nancy was born in 
Randolph, Vt., Sept. 3, 1788, as appears from the town records.

That he remained constantly in that town until the summer of 1793 is evident, for he was chosen Lister March 19, 1789, and was chosen Town Clerk March 8,1700 , and served the town in that capacity until March 18, 1793. As his name appears from time to time in the parish records of West Springfield previous to $17 S 8$, it is plain that ho lived there up to the time he sold his place; and from the facts we have before given, it is no less plain that from 1788 to 1793 , he resided in Randolph, Vt.

That he died in 1798, is shown by the record of births, marriages and deaths, in the town of Randolph, which reads "Justin Morgan died March 22, 1798;" and the same is inscribed upon his tombstone in the burying-ground at Randolph Centre, Tt. In the memoirs of Mrs. Emily Edgerton, (a daughter of Justin Morgan,) edited by Rufus Nutting, and published in 1832, is the following statement: "Among the early settlers of this town (Randolph) was Justin Morgan, Esq., the father of the subject of this biographical sketch. Emily was the sceond of his five children, and was born Feb. 16, 1781. In her seventh year, she was called to one of the most severe afflictions, the loss of a kind and faithful mother. $* * * * *$ Her affectionate father survived her mother about seven years." If this was correct, it might be said that Justin Morgan died in 1797 ; but there is evidently a mistake in say. ing her mother died when Emily was "in her seventh year," for her sister Polly was born March 10, 1791, or nearly one month after Emily was seven years old, 
and, as we have before stated, her mother aied March 20, 1791. (See town record.) Such an error may easily be accounted for by considering, that in the memoirs referred to, the exact date of her mother's death was not considered important, as is manifest from the general way in which it is stated, and the author evidently intended to convey no other idea than that when about seven years old, her mother died. A clear understanding of these facts is necessary, and its importance will appear from a consideration of what we shall say in regard to the foregoing extracts relating to the origin of Morgan horse:

The account of the origin of the Morgan horse, embodied in the affidavit of John Stearns, has been pretty videly circulated, and is undoubtedly believed by many to this day. The first objection that a thorough horseman would urge to this statement would be, that if descended from a Canadian sire, both he and his stock should bear a strong resemblance to that breed of horses; whereas nothing can be more clear than that in most of their leading fartures they are altogether unlike.

Mr. George Barnard, of Sherbrook, Canada East, who has devoted years to the breeding of horses, and who has owned, and we believe still owns, some very fine racing stock, is an intelligent gentleman, and all who know him must confess him to be reliable authority upon such a subject. In a letter to "The Albany Cultivator," under date of October, 25, 1841, he thus compares the Morgan with the Canadian horse: "In my communication on this subject, published in the late October number, I have expressed too conf. 
dent an opinion in saying $I$ believe the original horse (Morgan) was of French Canadian origin. I have recently had some acquaintance with a Morgan horse endowed with all the peculiarities of the breed, sufficient to make me forbear any decided opinion on the point in question, until very clear evidence is adduced. The affidavit which I furnished is only probable, and not conclusive testimony that the original horse was of Norman-French descent, and procured in Montreal.

The horse which has been with me of late is one of those called, from being in-bred, a full blooded Morgan -an absurd term, for it is impossible that a descendant can inherit full blood from a single progenitor. The term full-blood or thorough-bred can only be used with propriety where the distinctive appcllation is derived from a race or sort which furnished both parents; thus we may say a thorough-bred or fullblood English race-horse, a full-blood or thoroughbred Alderney cow, if both sire and dam were of the breed or sort designated. The term thorough-bred, however, has heretofore almost exclusively been applied to race-horses, because for centuries before the present, the racing breed of horses has been the only breed of animals highly cultivated, and of which the pedigrees could be proved by written or printed documents.

"All the accounts, being not less than half a dozen, which I have heard of the origin of the first Morgan horse, agree in this, that one Justin Morgan, of Randolph, Vt., from whom the name was derived, owned the animal while he was yet a colt. Doubtless there live persons who can testify to his origin, whether or 
not it be such as represented in the late affidavit. The public would be not only gratified, but greatly benefited by such evidence. There has probably never been another stallion whose stock for thirty or forty years have produced so much net profit to the growers.

"I will now endeavor to point out what appears to be the chief points of distinction between the Morgan breed and the horses of Norman-French descent, produced in Canada. Let me premise that a great varicty of races exists in the Canadian breed, yet all clearly impressed with a certain general character. The broad, courageous-looking head, with ears far apart, thickneck, with general stoutness of frame, full breast and strong shoulder, with a round or fleshy croup; the low-set muscles and large sinews, with those tough feet that know not disease, are distinguishing marks of the French Canadian horse.

"The shagginess or abundance of hair in the mane and tail and on the legs are much owing to the severity of the climate, with the manner of rearing the animals, and may be expected in a great measure to disappear under good cultivation, long before the inuate excellencies and peculiarities will perceptibly change.

"The Morgan horse does not partake of all these marks in common with the Canadian. The clear, and deep-toned bay color, too, which prevails in the Morgan, is rare among Canadian horses. It occurs in individuals; but unless characteristic of the race for a long period of time, it could hardly be supposed that this color would so generally occur as it does in the Morgan horses of the present day. Peculiarities produced by a 


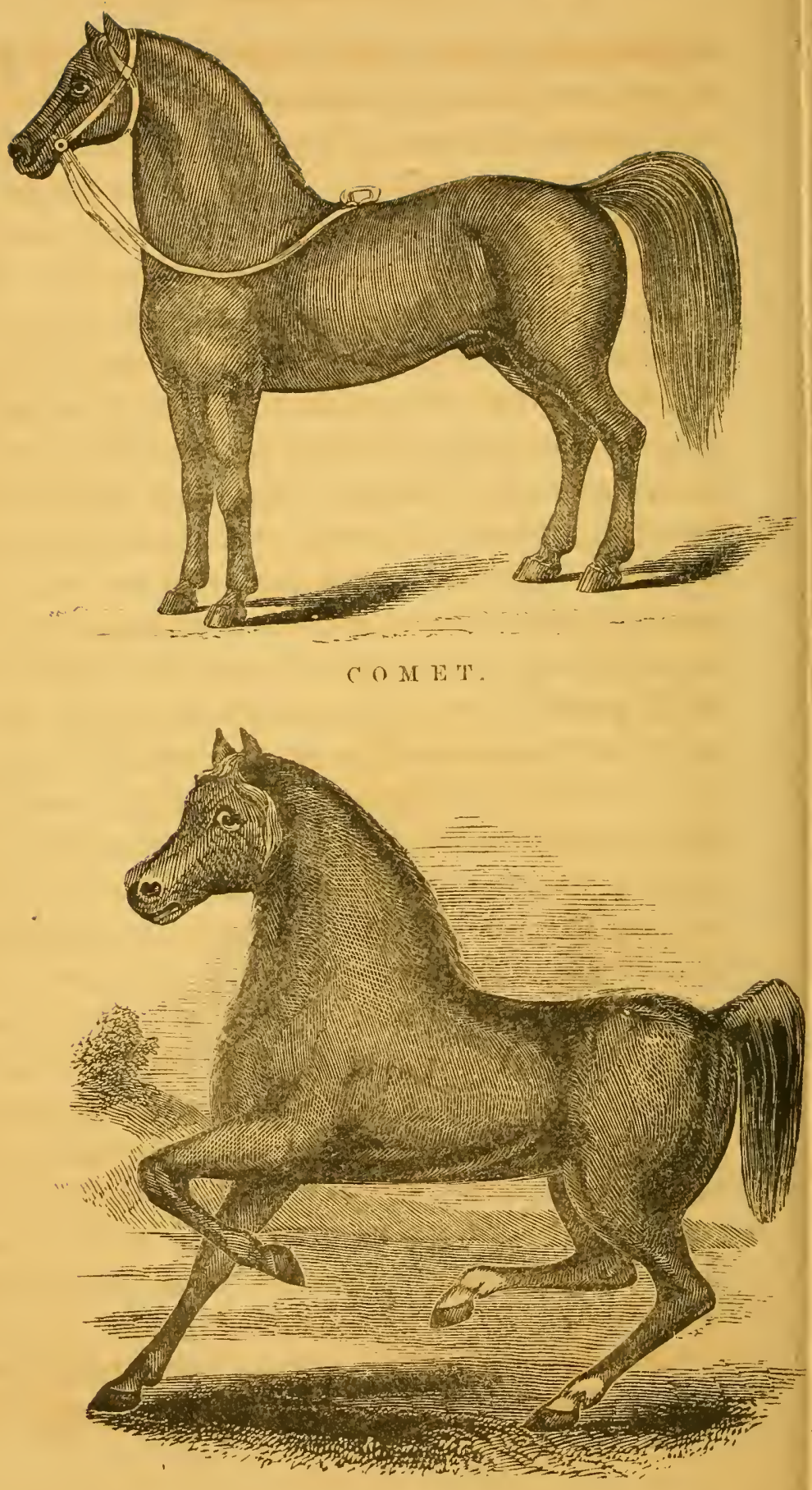

P P I N C E A I B E P T . 
single cross are apt to wear away in a few generations, unless maintained by careful selection on the part of the breeder. If, then (supposing the Morgan horse to have come from Canada), his color was an accidental variety, it would not have so generally marked his numerous offspring, unless great pains were taken to preserve it by selection, which has not been the case. It appears evident from the prevalence of this color through several successive generations, as well as the similar descent of various qualities, which are authenticated as having belonged to the first known sire, that the Morgan horse, whatever may have been its origin, was of one pure stock; that is, that he was not crossbred, or produced by the union of two different breeds; for in that case, there must have been a greater variety in his progeny; some running to one family, and some to the other, whereas a remarkable similarity is known to prevail in all of this race. And here we may notice that the breeder is apt to find an essential difference in the two races: the Morgan, crossed or mixed with the various common breeds, inclines to retain its peculiar characteristics and its small size in the offspring for many generations, while all the French Canadian races, though not larger for the most part than the Morgan, when used as a cross, increase the size of the progeny, and frequently assimilate so that the blood can only be recognized by a practiced observer, in the greater development and robustness of form, and the courage, spirit, and aptnoss to thrive, which are commonly reckoned as constitutional healtb.

"The Morgans differ essentially from the Canadian Lorses in their action or mode of travelling. A Mor- 
gan horse glides over the ground eight or nine miles an hour, with such easy movements of his legs, that one would think they only felt relieved when so employed; the Canadian, if he has speed, seems to go by main strength, every stricle arising plainly from a purposed exertion of his powerful muscles.

"Another principal cissimilarity is in the endurance of the feet; and here the Canadian horse has all the advantage. The Morgan appears to be subject, as much as equally strong-constitutioned horses of any breed, to founder, and other diseases of the feet, while with the Canadian such ailments are less known, perhaps, than with any other breed in the world. There are numbers of horses in Canada that, under a mass of shaggy hair, possess dry, sinewy legs, on which the severest service never raises a wind-gall. The legs of the Morgan, though destitute of long hair, have this excellent conformation in a very high degree.

"The Morgan is a great traveller; an untiring, allday horse, but seldom a very fast-trotter or galloper, and less frequently a perfect saddle horse. The Canadian, if he has the power of rapid locomotion, inclines for the most part to put forth his energies only for a short time, and then to take a leisurely gait, as if a slight sense of fatigue overbalanced the alacrity of his nervous system. There are, however, splendid exceptions to this description; horses that with no light load behind them will travel eighty and even ninety miles in a day. Some of the light-footed Canadian horses, too, are very pleasant under the saddle, though in general the weight of the neck and uprightness of the shoulder disqualify them for this use. The head of 
the Morgan, though not less energetic, is somewhat dissimilar to that of the Canadian. The ears of one are upright; of the other, more apart. The head of the Canadian horse is broader at the upper part than that of the other. Each has a great space between the eyes, which is considered a sure indication of energy in an animal. The Morgan has the best open nostril for wind and bottom, more like that of the race-horse; and the whole of the muzzle, as well as the eye and ear, indicate more breeding, or a longer cultivation than those of the Canadian. There is a difference of shape observable throughout the whole figure. The Morgan is long in the side, but always short on the back, and strong and beautiful in the loins. His fins shoulder, too, differs from that of the Canadian horse. It is deep, well-sloped, comparatively thin at the top, and heavy at the bottom, serving, conjointly with a wide chest, and the fore-legs set far apart, to give the horse an appearance of strength and endurance scarcely to be looked for in one of his spirit and fleetness. The high-crested neck, and thick wavy tail of the Morgan, show much of the character of some races of the Canadian.

"Whether the Morgan be a scion of the Canadian stock, or be derived from the Dutch, or some other breed which has disappeared in the UTnited States, appears to be a question of some importance to those who would make good selections in order to improve the breed of horses, and whoever can throw any light on the subject will gratify a large portion of your readers by making known his information through "The Cultitivator.' If the French Canadian did not supply tho 
Morgan, I, for one, should be glad to learn what other breed has ever been known upon this continent that could boast such exccllent qualities for common serv. ice as are universally admitted to distinguish both of these breeds."

The great difference in form, temper, and general character that exists between French Canadian and Morgan horses, as pointed out in the above letter, should cause us to receive with great caution any accounts ascribing his origin to the Canadian horse.

Had Mr. Barnard been, at the time he penned the foregoing, better acquainted with Morgan horses, he might have added to his list of important particulars in which the two breeds differ materially. The Morgan horse is remarkable for the projection of his ribs from the spine, giving him a wide back and a round barrel; while the Canadian horse is inclined to be flatsided. They differ much in their style of travelling: The Morgan raises his fore-feet but little, while the $\mathrm{Ca}$ nadian horse has a high and labored action of the forefeet. The Canadian horse is certainly very remarkable for the excellence of his feet, but, however the specimen Mr. Barnard had may have failed in this respect, poor feet are of very rare occurrence among Morgan horses.

These remarks apply of course equally well to all accounts that ascribe to the Morgan a French Canadian origin. As far as the affidavit of $\mathrm{Mr}$. Stearns is concerned, they are not indispensable, for it can easily be shown to be erroneous. Mr. Stearns fixes the date of the Justin Morgan's first appearance in St. Johnsbury in June of 1804, which is perhaps correct. He says: 
"Uncle John said he was a Canadian horse that he had got from Justin Morgan, of Randolph, who had lately brought him from Montreal" - that is to say, within a few weeks, that spring, or, perhaps, the previous winter. Now, Justin Morgan died March 22d, 1798 , or six years previous to this time, as we have shown.

With regard to the statement of Mr. Cottrel, as rendered by Mr. Weissenger, it will be observed that Mr. Cottrel by no means undertakes to vouch for its truth; he does nothing of the sort, he merely gives it as the most probable account, the most plausible story in relation to it that he has heard.

If there was no direct proof to contradict it, this story would be entitled to very little credit. It lacks any definite points-it is stated in the loosest and most general way. Mr. C. does not give Mr. Morgan's christian name, and our only reason for inferring that the Morgan here spoken of and Mr. Justin Morgan, are one and the same individuals, is the statement that he owned the founder of the Morgan breed of horses, and the identity of their vocation - each being a singing teacher and living in the same vicinity; for although. Mr. C. does not tell us where Mr. Morgan lived, we are left to suppose that he lived somewhere in the neighborhood of Mr. C., at least in that section of the country. We are not told at what time this Mr. Smith sold this colt to Morgan, or how old the colt was when sold; he does not explain how it was that a man owning a fine imported mare, which we are allowed to infer must have been nearly if not quite thorough-bred (for we are immediately told that the colt became celebrated for running 
short races), should set no value upon her offspring, which from almost any kind of sire must have been valuable at a time when racing stock was in such demand and was so rare. But we will not pursue this subject further, as the letter of Justin Morgan, the younger, seems to us perfectly clear and conclusive on this point; and it is, moreover, confirmed by a great many persons who were neighbors of Mr. Morgan's at the time he brought the colt from Massachusetts.

Mr. David Gose, a man of high standing and character, who owned the original Justin Morgan seven years, says there is no doubt that the horse came from Springfield, Mass. Mr. Goss further says, that he had no written pedigree of the horse, but that he bought him believing him to be partly thorough-bred, and that no question was ever made of it, so far as he knew, during the lifetime of the horse. The letters of Justin and John Morgan comprise all the important fucts that can now be obtained in relation to the place where the horse originated; and we can see no reason to doubt that he was sired by True Briton, as is clearly and distinctly stated by Mr. J. Morgan. No account of the pedigree of the horse was reduced to writing during the lifetime of Mr. Justin Morgan, and the accounts he gave verbally have been remembered somewhat differently by different individuals. All accounts (as before remarked) agree that he had racing blood in his veins; some insist that it came from the sire, some that it came from the dam, and still others that it came from both. Even if we had no evidence, except what is derived from the descriptions given of him and from his stock, we should know that he was not a stranger to blood. 
His clean, lean head-his broad forehead-bold, full and prominent eyes-delicate ears, and flat, bony legs, give unmistakable evidence of a large infusion of racing or Arabian blood. Youatt says: "Few things indicate more clearly the blood of the horse than the form of the frontal bones. Who has not remarked the broad, angular forehead of the blood-horse, giving him a beautiful expression of intelligence and fire, and the face gradually tapering from the forehead to the muzzle, contrasted with the large face of the cart or dray-horse, and the forehead scarcely wider than the face. It is equally true, that his exceedingly compact form, short and upright pasterns, his short stride, and the small space between the hip-bones and ribs, assure us of a different origin in part.

With regard to his sirc, we think there can be no reasonable doubt that he was sired by True Briton, as John Morgan positively states. The fact that Mr. Morgan kept True Briton two years, adds great weight to his testimony, for it not only shows that he had the best means of knowing the facts he states, but his interest in the horse would fully account for his remembering them distinctly so long a time. But with regard to the blood of True Briton, Mr. Morgan does not state positively - though he is not in doubt as to the fact of the horse having been purchased by Mr. Joseph Ward, of Hartford, Conn., for three hundred dollars, of some person who was said to have stolen him from Gen. De Lancey.

The letter of John Morgan seems to us conclusive evidence with regard to the sire of the Justin Morgan. John Morgan was a man of high character for candor, 
truthfulness and intelligence. He lived at Springfield at the time the Morgan horse was sired, and at the time Justin Morgan removed to Vermont. He kept True Briton, or Beautiful Bay, two years, and he states that Justin Morgan kept him one year. Living on the ground, and being interested in the sire of the Morgan horse, he had every mcans of knowledge. His letter contains within itself evidence of the care and caution of John Morgan. When he speaks of facts known to himself, he states them positively: as, that he was sired by True Briton, or Beautiful Bay, owned by Selah Norton, of Hartford, Conn.; that he was kept at Springfield one season by Justin Morgan, and two years afterwards was kept two seasons by himself. When he comes to speak of the origin of True Briton, he does not say that he was raised by Gen. De Lancey, though he no doubt believed so, but with commendable caution he says, he (True Briton) "was said to be raised by Gen. De Lancey, commander of the refugee troops on Long Island, and rode by him in the Revolution. It was said that one Smith stole the horse from the General, at King's Bridge, while the General was in the tavern, ran him across the bridge and took him to the Ameri. can army, near White Plains, and sold him to Joseph Ward, of Hartford, Conn. It was also said at that time, that he was sired by the noted imported horse called the Traveller, said to be kept in New Jersey." Again: when he comes to speak of Ward, he says positively that Ward was a merchant, and kept the horse three or four years for a saddle and carriage horse, and traded him off to Norton, \&c., for these facts were within his own knowledge and he was certain. Again, when he 
comes to speak of what became of the colt, we observe the same caution. He says: "I have always understood that Morgan kept the colt for a stud at Randolph, and was very celebrated for his stock." The considerate reader of this letter will not fail to see that it contains the strongest evidence of the honesty and sincerity of John Morgan, and that it shows (what is nearly as valuable in such a matter) that John Morgan thoughtfully and carefully distinguished between what he had a personal knowledge of and what he believed on the statements of others. If all inquirers on this subject had used the same care, much error would have been avoided.

Mr. Morgan is not, however, the only authority in relation to the blood of 'True Briton. In "The Connecticut Courant" for April 26th, 1791, appeared an advertisement of Selah Norton's, from which the following extracts are made:

"Beautiful Bay will cover (for the benefit of the public) for 15s. the season, eash or grain, next fall. * * * * His sire was the imported horse Traveller, owned in New Jersey. His dam, De Lancey's imported racer. Ten pounds was offered for one of his colts when ten days old, at Lanesborough. * * * $\quad$ He is in his prime, in fine order, bright bay, fifteen hands high, trots and canters very light. * * "SELAH NORTON."

In the above advertisement, it is stated that he had been kept at Springfield, which corroborates the statement of John Morgan.

The fact that True Briton was stolen from General 
De Lancey, at King's Bridge, seems to admit of little doubt, for the story is confirmed by many persons living in Connecticut, who well recollect the occurrence, and we have never heard but one version of the story in all its main features, though told by many different individuals.

The striking harmony that may be noticed between these accounts of the manner in which True Briton was brought into Connecticut, is very strong evidence of their correctness; and the harmony is itself accounted for, by the singular manner in which he was obtained.

Such a fact, as the stealing of a valuable horse from a British officer, and escaping with him, was no every. day occurrence. It would be known to all the surrounding country in a very short time, and the man who stole him, instead of being shunned as a thief, would be respected as the hero of a successful foray into the enemy's country.

The fact that the horse was a valuable one, and was, after a time, kept for a stock horse, in that section of the country, would tend to keep alive in the minds of those who knew him, the singular circumstances of his coming into the country. Although Mr. John Morgan does not assert that True Briton, or Beautiful Bay, was sired by Traveller, yet it is plain that he believed - him to be: and Mr. Norton, in the advertisement just quoted, distinctly states it. To this statement it may be objected, that Norton might have been in error, for admitting that the horse was stolen from De Lancey, it is not likely that Norton could have obtained a written voucher of his pedigree from his previous owners; for horse thieves, though they often manifest 
excellent judgment in the choice of animals, yet they rarely take much pains to secure their pedigree. But it must be remembered, that though the owners of True Briton may have had no written certificate of his pedigree from his breeder, yet there were many ways in which it could be established. De Lancey was a man of fortune and notoriety, and had many servants who would know as much of the pedigree of his favorite horse, as he did.

Selah Norton was, in early life, a man of property, and an enthusiastic admirer of fine horses. Elis interest in the horse would have prompted him to make every exertion to discover his pedigree, and that he did so seems evident, from the direct manner in which it is stated in the advertisement before mentioned, and also from the additional consideration, that such was generally believed to be the fact at that time, and so far as we can learn, was entirely undisputed.

With regard to the dam of True Briton: Mr. Norton asserts that she was "Mr. De Lancey's imported racer." We believe there is no record of any importation of such an animal by De Lancey, except the celebrated Cub mare, which he brought from England with Wild-air. But had True Briton been sired by Traveller, and foaled by the Cub mare, he could hardly have escaped being noticed by "The American Farmer," or "Turf Register," especially as the produce of the Cub mare was published in the Register, though not until many years after.

While it may be doubted if the Cub mare were the dam of True Briton, or even whether his dam was imported, it seems to us altogether probable that she 
was a high-bred animal, for an officer of De Lancey's rank, wealth, and taste for horses, would not only have been "well mounted," but he would not have been likely to use for the saddle a horse not highly-bred, especially as his father's stables gave ample scope for the selection of a fine animal of this description; nor, on the other hand, is it probable that he rode a stallion whose pedigree could be traced, on the side of both sire and dam, through the best families of the English race-horse without a flaw, (as it could have been, had he been sired by Traveller, and his dam the Cub mare,) for such a horse, had he been a good riding animal, would have been very valuable, and highly prized by breeders of race horses, and would have been kept exclusively for stock. General De Lancey (we think he was a Colonel), from whom True Briton was stolen, was not (as has been sometimes supposed) the importer of Wild-air, Lath, the Cub mare, \&c. ; these horses were imported by his father, James De Lancey, a son of Lieutenant-Governor James De Lancey, a wealthy and prominent man, and for many years a member of the General Assembly of the State of New-York; he was an extensive breeder of race-horses, and owned many celebrated animals in addition to those we have mentioned. He visited England in 1775, and the war soon after breaking out, he never returned.

L. G. Morris, Esq., of Fordham, N. Y., in his "Sixth Catalogue of Domestic Animals," page 79, gives another account of the origin of True Briton. After giving an extract from John Morgan's letter, he says: "The other account I got in person, from Mr. Andrew Corsa, a near neighbor of mine, and ninety years old. Mr, 
Corsa resided within the lines and near King's Bridge, during the Revolution; he knew General De Lancey well, and also his horse which Smith stole from him at King's Bridge.

"Upon direct inquiry of Mr. Corsa, upon whom I called with Mrr. Howard of 'The Boston Cultivator,' expressly to inquire as to the above horse, he stated he was blood bay of fine size and strength, and he had repeatedly seen Gen. De Lancey jump him back and forth over a five-rail fence, for the amusement of bystanders, and that he understood him to have been a horse sent over from England." The only respect in which this account differs from the one we have given is, that Mr. Corsa says: "he understood him to be a horse sent over from England." It seems MIr. Corsa was ninety years old at the time he gave this information, and in estimating the value of his testimony, much allowance must be made for the infirmities of age, and the long time that had elapsed since the events of which he speaks transpired. So the nature of the different facts he states must be considered; for while the fact that a fine looking bay horse should be made to jump a five-rail fence, in the presence of a collection of people, would be likely, from its novelty and interest, to make a lasting impression on all who saw it; yet few of the spectators, if informed of the pedigree of the horse at the time, would loing remember it.

So that even had Mr. Corsa stated that True Briton was an imported horse, it could hardly be allowed to weigh against the published statement of Mr. Norton, who was the owner of True Briton, and published his pedigree while the horse was in his prime, and when 
we cannot doubt that the fact of his having been imported could have been easily ascertained had it been the cass. Nor can we for a moment suppose that Mr. Norton would fail to publish the fact, were it true, for he had abundant means of ascertaining, and the value of the animal as a stock horse would have been much enhanced could he have established it.

But Mr. Corsa does not say that True Briton was an imported horse; he simply says he "understood him to have been a horse sent over from England," and certainly such a loose, general, and indefinite assertion made by a man of Mr. Corsa's age, concerning a matter some seventy years old, and a matter in which he had no direct interest, can be entitied to but little weight. Immediately after the passage we have already quoted from the catalogue of Mr. Morris, is the following sentence: "The 'Black Hawk' and 'Morgan' of the present day seem to differ in appearance from the original stock, as they are rather on the pony order, and very seldom more than fifteen hands high."

Mr. Mormis is evidently mistaken as to the size of True Briton, for he manifestly believes him to have been a fine horse, while, according to the standard he sets up, he was simply a pony, as it will be seen that Mr. Norton does not claim he was a fraction over fifteen hands ligh.

Finally we repeat, that though the owners of True Briton in Connecticut may have had no written evidence of his pedigree from his breeder, yet they may have been able to satisfy themselves and the public that he was sired by Traveller, and from a highlybred, if not an imported mare; and it is very certain 
that such was generally believed to have been his origin.

That he was a very valuable animal is evident from the price Ward paid for him, three hundred dollars being as extravagant a price for a carriage or saddle horse at that day as one thousand dollars would be now.

With regard to the pedigree of the dam of the Justin Morgan, the only statement we remember to have seen is that published by F. A. Weir, as we have already given it. If this pedigree is correct, the dam must have been at least three-eighths thorough-bred. But there is a grave mistake in the very first sentence of the account published by Mr. Wier, that very materially diminishes the credit that might, perhaps, otherwise attach to the rest of the history. He says, "The dam of the Justin Morgan horse at the time he was sired, was owned by Justin Morgan himself, at Springfield, Mass., where he then lived;" and he says (as was no doubt true), that he was foaled in 1793, consequently he was sired in 1792 ; but Mr. Morgan, as we have already shown, removed from Springfield to Randolph, Vt., with his family, in 1788, and remained constantly at Randolph until 1793; and as he was a poor man, and owned no real estate in Springfield, it is not likely that he owned and left any horses there.

Mr. Weir says Mr. John Morgan describes the dam of the Justin Morgan as of the Wild-air breed, and this may have been so; but some degree of doubt must necessarily attach to any statements made by persons of an advanced age, concerning the pedigree of animals possessing no remarkable qualities that 
did not belong to them, and that lived and died many years before. If this statement of Mr. Morgan was correct, it does not assert that the dam was thoroughbred, it means simply that she had some of Wild-air's blood in her veins, just as we now say a mare is of the "Messenger breed," who may not have one-twentieth of Old Messenger's blood in her.

If we may be allowed to judge of the correctness of this pedigree from the appearance of the descendants of the Justin Morgan, we should say there could be no reason to doubt his near relation to the thoroughbred or Arabian; for even those who think least of the Morgan breed of horses, agree that they must have sprung from "rich high blood," as even the "distinguished judge of horses from Vermont" admits it.

It is thought by some that the dam of the Justin Morgan was a descendant of Lindsey's Arabian, which was imported into Connecticut in 1766, being then four years old. This idea seems to have been founded principally upon the resemblance of the Justin Morgan to the stock of that celebrated horse, and indeed we are not aware that there is any other ground for this opinion; still it is entitled to some respect, for a close and striking resemblance between different animals in most of their leading characteristics, is certainly strong evidence of their relationship. There can be Iittle question that there was a strong resemblance between them. The descendants of the Lindsey Arabian were celebrated for their compactness, speed and endurance, and for an exceedingly playful and tractable temper; they were highly esteemed throughout Connecticut and Massachusetts, and were most numerous 


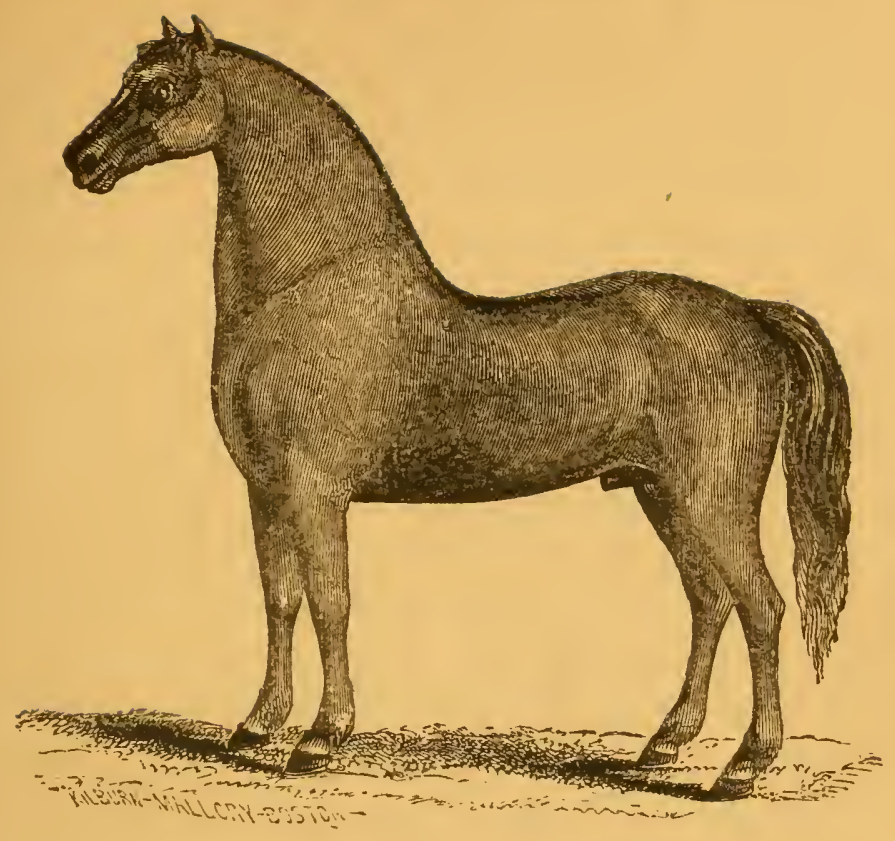

$\mathrm{V}$ E R M O T

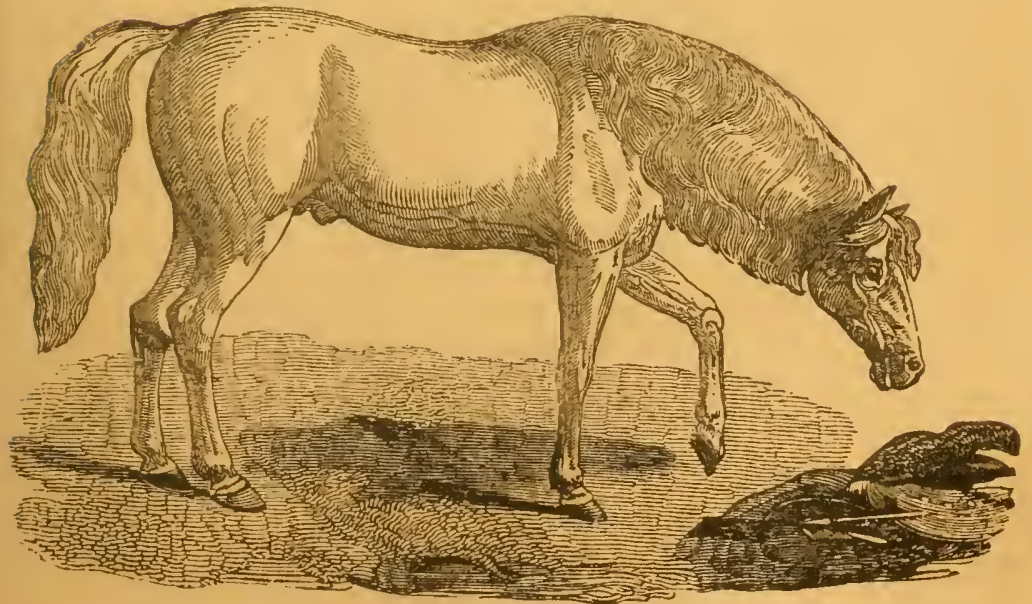

S T R A N G R . 

along the valley of Conuecticut River. Many of the cavalry engaged in the siege of Boston, in 1775 and 1776, were mounted on these horses, and their extraordinary qualities attracted the notice of General Washington. Acting upon his advice, Mr. Lindsey found and purchased the horse that has since borne his name, and took him to Virginia. Previous to this time he had been called Ranger. Not only had the stock of this horse become well and favorably known in the localities we have mentioned, but at that time a graat deal of interest was manifested throughout the country in Arabian or thorough-bred stock, and it is evident that Ranger was, then, the sire of a very numerous progeny, or they would not have been in the army in sufficient numbers to attract the attention of the Commander-inchief. It cannot, therefore, fairly be objected to this hypothesis, that the descendants of the Lindsey Arabian were too uncommon to render it probable.

A strong resemblance to the Aration, True Briton would derive through his sire, as few horses have been imported from England so nearly related to Arabians as was Morton's Traveller. He was foaled in 1748 , and was imported to Virginia when about five years old. He was got by Croft's Partner. Partner was by Jigg, a son of the Bycrly Turk, and his dam was by Curwen's Bay Barb, his g. dam was by Sport, and his g. g. dam by the chestnut, white legged, Lowther Barb. The dam of Morton's Traveller was by Bloody Buttocks, an Arabian. It has been often stated that Morton's T'raveller was by O'Kelly's Eclipse, his dam by King Herod, grand dam by Blank, great grand dam by Cade, and Carle by the Godolphin Arabian, \&c. This, however, is 
a mistake, the latter pedigree being that of another "Traveller" imported in 1797. This pedigree was published as the pedigree of Morton's Traveller in the third volume of the "American Turf Register," but was corrected in the seventh volume, and is also correctly stated in the fourth volume, page 43 .

It may be said, by some, that it is surprising nothing should be found among the papers of Justin Morgan relating in some way to this horse, and that we should expect the different owners of the horse would have made every effort to ascertain his pedigree, and that some of them would have succeeded, as at that time many persons must have been living in Massachusetts who at least knew his dam and her sire.

The answer to the first objection is, that none of Justin Morgan's papers or books have been preserved in the family, not even a letter or a family bible. As before stated, his family was broken up in 1793 or 1794, and from that time until his death in 1798 , he may be said to have had no home, but lived first in one neighborhood while he could find employment as a teacher, and then removing to some new field. At the time of his death, his children had not attained their majority, and there being no one to look after them, his papers (if he had any) were lost. Nor was it likely that he gave any written statement of his pedigree to some third person, for it must be remembered that he was not a farmer, or a breeder of horses, and he had not brought his horse to Vermont to improve the breed of horses there; but he kept him to ride from school to school.

Thus situated, it could not be expected that he would 
make any effort to bring him into favor with his farm. ing neighbors by explaining his pedigree, and enlarging upon the noble and extraordinary qualities of his ancestors. Still, as he had owned the horse since he was two years old, he would know something of his pedigree, and would be apt occasionally to mention it to such persons as saw and admired his spirited colt. Finally, it must be remembered that Morgan died before his horse had arrived at full maturity.

The reason why no effort was earlier made to ascertain his pedigree by his owners, or others, was that for a long time he was not fully appreciated. After Mr. Morgan's death he passed into the hands of persons who had but a poor opinion of him, and instead of keeping him expressly for stock, put him to the severest kinds of labor, and it was not until several years had elapsed, and his colts began to be highly esteemed, that any inquiry was made as to his pedigree. So much time had then elapsed since he came into the country, that it was then attended with much difficulty ; and any one who has tried it, must bear witness, that tracing genealogies is one of the slowest and most perplexing kinds of business. This, together with the want of any easy and rapid communication between different parts of the country to facilitate inquiry, seems to have prevented any persistent search for the facts.

We have devoted more time and space to this subiect than may be thought advisable by some of our readers, as no pedigree, however perfectly it might be established, or how far back it might be traced, through any breed of horses, could enhance the value of the race at the present time; for, as an intelligent writer 
has observed: "Before animals have produced progeny, the best evidence of what their progeny will be, is what their ancestors have been, because there is a tendency to breed back. Animals of the same blood, however, are not equally valuable as breeders; hence, the surest evidence of the value of a breeding animal, is the character of the stock it produces. Thus the value of pedigree consists in affording, in advance, an indication of the value of an animal as a breeder, but the character of the offspring and descendants may be regarded as exhibiting the degree of value it possesses; the one may be regarded as prima facia evidence, the other as demonstrative." Pedigree is, however, valuable in another respect, and cannot be too carefully preserved by breeders. By preserving the pedigrees of animals, we are enabled to see the result of the various crossings of different breeds and families; can shun the errors of former generations, and take advantage of their success. 


\section{CHAPTER VI.}

MEMOIR AND DESCRIPTION OF THE JUSTIN MORGAX.

Tine original, or Justin Morgan, was about fourteen hands high, and weighed about nine hundred and fifty pounds. His color was dark-bay with black legs, mane and tail. He had no white hairs on him. His mane and tail were coarse and heavy, but not so massive as has been sometimes described; the hair of both was straight, and not inclined to curl. His head was good, not extremely small, but lean and bony, the face straight, forehead broad, ears small and very fine, but set rather wide apart. His eyes were medium size, very dark and prominent, with a spirited but pleasant expression, and showed no white round the edge of the lid. His nostrils were very large, the muzzle small, and the lips close and firm. His baek and legs were perhaps his most noticeable points. The former was very short; the shoulder-blades and hip bones being very long and oblique, and the loins exceedingly broad and muscular. His body was rather long, round and deep, close ribbed up; chest deep and wide, with the breast-bone projecting a good deal in front. His leg's were short, close jointed, thin, but very wide, hard and free from meat, with muscles that were remarkably large for a horse of his size, and this superabundance of muscle exhibited itself at every 
step. His hair was short, and at almost all seasons soft and glossy. He had a little long hair about the fetlocks, and for two or three inches above the fetlock on the back-side of the legs; the rest of the limbs were entirely free from it. His feet were small but well shaped, and he was in every respect perfectly sound and free from any sort of blemish. He was a very fast walker. In trotting his gait was low and smooth, and his step short and nervous; he was not what in these days would be called fast, and we think it doubt. ful whether he could trot a mile much if any within four minutes, though it is claimed by many that he could trot it in three.

Although he raised his feet but little, he never stumbled. His proud, bold and fearless style of movement, and his vigorous, untiring action, have, perhaps, never been surpassed. When a rider was on him, he was obedient to the slightest motion of the rein, would walk backwards rapidly under a gentle pressure of the bit, and moved side-ways almost as willingly as he moved forward; in short, was perfectly trained to all the paces and evolutions of a parade horse; and when ridden at military reviews (as was frequently the case), his bold, imposing style, and spirited, nervous action, attracted universal attention and admiration. He was perfectly gentle and kind to handle, and loved to be grocmed and caressed, but he disliked to have children about him, and had an inveterate hatred for dogs, if luose always chasing them ont of sight the in. stant he saw them.

When taken out with halter or bridle he was in con. stant motion, and very playful. 
He was a fleet runner at short distances. Running horses short distances for small stakes was very common in Vermont fifty years ago. Eighty rods was very generally the length of the course, which usually commenced at a tavern or grocery, and extended the distance agreed upon, up or down the public road. In these races the horses were started from a "scratch," that is, a mark was drawn across the road in the dirt, and the horses, ranged in a row upon it, went off at "the drop of a hat" or some other signal. It will be observed that the form of the Justin Morgan was not such as in our days is thought best calculated to give the greatest speed for a short distance. Those who believe in long-legged racers will think his legs, body and stride, were all too short, and to them it may perhaps seem surprising that le should be successful, as he invariably was, in such contests. Butwe think his great muscular development and nervous energy, combined with his small size, gave him a decided advantage in the first start over taller and heavier horses; just as any ordinary horse can distance the finest locomotive in a ten rod race. At all events, the history of racing in this country and in England, proves conclusively, that small horses may have great speed. In such a race a Lorse of great spirit and nervous energy derives a decided arlvantage from these qualities, especially after being a little accustomed to such struggles. When brought up to the line, his eyes flash and his ears quiver with intense excitement, he grinds the bit with his teeth, his hind legs are drawn under him, every muscle of his frame trembles, and swells almost to bursting, and at the given signal he goes off like the springing of a-steeltrap. His un- 
varying success in these short races may perhaps be partly accounted for in this way, though he was undoubtedly possessed of more than ordinary speed, and was a sharp runner.

Among the many races of this description that he ran, were two in 1796, at Brookfield, Vt., one with a horse called Sweepstakes from Long Island, and the other with a horse called Silver Tail from St. Law. rence Co., New York, both of these he beat with ease. Mr. Morgan (who then owned him) offered to give the owner of Silver Tail two more chances to win the stake, which was fifty dollars, by walking or trotting the horses for it, which was declined. There are many accounts of other races which he ran and won, but these accounts not fully agreeing as to the details, we have not mentioned them.

In harness the Justin Morgan was quiet but full of spirit, an eager and nimble traveller, but patient in bad spots; and although for a long time steadily engaged in the heavy work of a new farm, his owner at that time informs us that he never knew him refuse to draw as often as he was required to, but he pithily adds: "I didn't very often have to ask him but once, for whatever he was hitched to generally had to come the first time trying." This uniform kindness at a pull, was one of the striking characteristics of the horse, and the same trait may be observed in the greater part of his descendants. "Pulling matches" and "pulling bees," were as common in those days as short races, and the "little horse," as he was often called, became quite celebrated for his unvarying willingness to do his best, and for his great power at what is called a "dead lift." 
The following letter from Solomon Steele, Esq., of Derby, Vt., a gentleman who has devoted a great deal of time and money to the improvement of horses in his vicinity, and who, notwithstanding the apathy of some, and the opposition of others, now enjoys the pleasure of seeing his precepts adopted, and his example followed by his neighbors, to their great advantage, and the equal improvement of their stock, will be read with interest:

\section{"Derby Line, Vt., March 12th, 1856.}

"D. C. Linsley, Esq.

"Dear Sir:-I am in receipt of yours of the 1st. inst., renewing your request that I should favor you with such information as I may possess, in relation to the early history of the founder of that breed of horses, which have, at length, become so distinguished as to be called the 'best in the world,' and known as Morgans.

"I have not the vanity to presume that I can disclose any material facts relative to this subject, but, at your request, I will mention some incidents connected with the early history of this horse, which if not of great importance, may not be void of interest. It has been my privilege, in early life, to often see the original Morgan horse, called by this name from the fact that Justin Morgan brought him to Randolph, Vt., from Massachusetts, in the autumn of 1795. Mr. Morgan intended to apply him to the payment of a note held against him, but not being able to obtain what he considered a reasonable price for him, and having no keeping for him, he let him to a man by the name of 
Robert Evans, for one year, for the sum of fifteen dol. lars. Immediately after this, Evans undertook the job of clearing fifteen acres of heavy-timbered land for a Mr. Fisk, and before the first of June following, had completed the job, with no other team but this colt, though not regarded as a 'salable horse.'

"While Evans was engaged in piling this timber, the remarkable powers of this horse, it would seem, were in a measure developed, as he was then found able to out-draw, out-walk, out-trot, or out run every horse that was matched against him. An instance was related to me by Mr. Nathan Nye, who was an eyewitness, and whose testimony was never questioned. I noted it at the time, and will relate it in his own words:

"'At the time Evans had this horse, a small tavern, a grist-mill, and saw-mill were in operation on the branch of White River, in Randolph, and at this place the strength of men and horses in that settlement, were generally tested. 'On one occasion' (says Nye), 'I went to these mills, where I spent most of a day, and auring the time, many trials were had, for a small wager, to draw a certain pine log, which lay some ten rods from the saw-mill.

" "Some horses were hitched to it that would weigh twelve hundred pounds, but not one of them could move it its length. About dusk, Evans came down from his logging field, which was near by, and I told him the particulars of the drawing match. Evans requested me to show him the log, which I did; he then ran back to the tavern and challenged the company to bet a gallon of rum, that he could not draw the log 
fairly on to the logway, at three pulls with his colt. The challenge was promptly accepted, and each having "taken a glass," the whole company went down to the spot.

"Arrived on the ground, Evans says: "I am ashamed to hitch my horse to a little log like that, but if three of you will get on and ride, if I don't draw it, I will forfeit the rum." Accordingly, three of those least able to stand were placed upon the log. I was present with a lantern, and cautioned those on the log to look out for their legs, as I had seen the horse draw before, and knew something had got to come. At the word of command the horse started, log and men, and went more than half of the distance before stopping. At the next pull, he lander his load at the spot agreed upon, to the astonishment of all present.

" Not many days after this, the beaten party pro. posed to Evans to run a certain horse against his, eighty rods for another gallon. Evans accepted, went from his work, and matched his horse against four different horses the same evening, and beat them all with ease.'

"Thus early in the history of the Morgan horse it was an admitted fact, that however small, he could not be beaten, where strength, speed, and endurance were the test. When we see this same animal driven in harness, or ridden by the aged and infirm with perfect safety and confidence, and next see him at a military review, mounted by the commander-in-chief, and dis. playing all the fire and pride imaginable; and after the lapse of nearly fifty years, witnessing the same remarkable traits in many of his descendants, we are 
constrained to admit, that blood is, indeed, of no small importance in the business of horse-breeding. It should be well understood, that throughout the long life of the Justin Morgan (as well as that of his immediate offspring), want of size was the universal objection. No man of ordinary judgment could fail to discover his peculiar points of excellence, his oblique shoulders, high crest, fine ear, prominent and sagacious eye, perfect head, large and expanded nostrils, strong loins, long hip, deep and well-spread chest, high withers, short pasterns, strong and sinewy limbs, with all the important muscles far surpassing in size those of any other horse of his weight ever seen in America. The fact that this horse has contributed more than any other animal ever did, to the wealth of the United States, no honest man will deny, but strange to say, in the face of all this, the cry is still heard, too small, too small. This reminds us of the man who sold his hen, because she was too small, although she daily laid eggs of gold. We rejoice, however, that we live in a day when intelligent men cannot so easily be made the dupes of interested parties. The farming community are thinking and acting with more care and attention than formerly, they are disposed to profit by past experience, they are more close observers of cause and effect, and it is our firm conviction, that the man who is doing most to foster and encourage this principle, is the world's greatest benefactor."

Through life the Justin Morgan was steadily employed in the heavy work incident to the cultivation of a new and mountain country, and was often engaged in similar matches to those just mentioned. Even at 
the age of fifteen we find him entered at a drawing match that took place at Gen. Butler's tavern, in St. Johnsbury. Some of his opponents are described by persons present as large, heavy horses, yet they were all beaten by the Justin. We mention these facts to show the great muscular development of the horse, and his kind and tractable temper, rather than as an evidence of his value for purposes of heavy draught; for, although the power of an animal in starting a given weight depends more upon his form and muscular development than upon mere size, yet size is indispensable to enable a horse to move off easily upon the road with a heavy load.

The quietness and exceedingly pleasant temper of the Justin Morgan, is strikingly evidenced by the fact that he was often ridden and driven by ladies. A lady of St. Johnsbury once told us she remembered his appearance perfeetly, and had repeatedly ridden him, when a girl, to balls and other parties, and spoke with much enthusiasm of his noble appearance, his high spirit, and perfect docility.

It is exceedingly difficult to obtain accurate information respecting the changes in owners that oceurred to the horse at different times. To aceount for this uncertainty, we must consider that his fame has been almost entirely posthumous, that although the champion of his neighborhood, he was little valued, on account of his small size; and it was not until after his death, and his descendants were exhibiting the powers of their sire, in speed, strength, and enduranee, in almost every village of Easiern Vermont, that people began to realize they had not properly appreciated him. For 
this reason, little notice was taken, at that time, of any change of owners, and many persons who very well recollect the horse, recollect nothing of these changes; and those who claim to recollect them, disagree much as to the dates at which his several owners purchased him.

We have made every exertion to collect the most reliable information in relation to this subject, but from the difficulties just mentioned, we fear our chronology may not prove perfectly accurate, but believe it to be in the main correct, and sufficiently so for all practical purposes, as the subject derives its chief importance from the curiosity felt in relation to it, by those interested in his descendants.

As we have before stated, Mr. Morgan used him almost exclusively as a riding horse, though he broke him to harness and occasionally used him in that way. After Mr. Morgan's death, he was sold by the estate to William Rice, of Woodstock, Tt. Mr. Rice used him in the ordinary work of his farm for about two years, or until 1800 or 1801, when Robt. Evans (who had been constantly on the watch for an opportunity to purchase, since he hired him of Mr. Morgan) bought him. Mr. Evans was a poor man, with a large family, and was what is called a great worker. In addition to the work upon his own place, he was constantly undertaking jobs for his neighbors-clearing land, hauling logs, building fence, \&c., \&c. The "little horse" was Mr. Evans' only team, and of course his labor was very severe. Mr. Evans kept him three or four years, or until 1804, when he was sued for debt; Col. John Goss became his bail, took the horse for security, and finally 
paid the debt and kept him. Mr. John Goss was not much of a horseman, and therefore took the horse to his brother, David Goss, of St. Johnsbury, who was quite a horseman, and made arrangements with him to keep him for a stock horse. After David had kept him a year, he was so much pleased with him that he exchanged a fine mare with his brother for him, adding cash or other property. The horse in this trade was valued at one hundred dollars. Mr. David Goss kept him seven years, or until 1811, and it was while owned by him that the Hawkins; Fenton, and Sherman horses were sired. Mr. Goss kept him almost constantly at work on his farm, with the exception of about two months in the spring of each year. While his property, although put to hard work, the horse was not overworked or abused, but was properly treated and cared for. David Goss sold him to his son Phillip, and some of his colts about Randolph having grown up and proved valuable, there was some inquiry for the horse in that vicinity, and he was accordingly taken back to that town. This was in 1811. He was now nineteen years old, and those who owned him at different times after this, generally seemed eager to get rid of him, for fear he should die on their hands. Immediately after his return to Randolph, he seems to have been taken care of by Robt. Evans, his former owner, for it was during this year that Bullrush was sired, and he was at that time in the possession of Mr. Evans. Soon after this, or in the autumn of 1811, Phillip Goss sold him to Jacob Sanderson; Sanderson sold him to a Mr. Langmade, who used the old horse hard, considering his age. He worked him some time in a six-horse 
team, hauling freight from Windsor to Chelsea. Under this treatment he became thin and poor, and was purchased for a trifle by Mr. Chelsea, and shortly after sold by him to Joel Goss, of Claremont, N. H. Mr. Goss kept him one year, and sold him to Mr. Samuel Stone, of Randolph. Mr. Stone kept him two or three years, or until 1819, when he sold him, and he soon after became the property of Levi Bean, who owned him until his death, which happened in the winter of 1821 , at the farm of Clifford Bean, situated about three miles south of the village of Chelsea, Vt.

At twenty-nine years of age, no cause need be assigned for his death but the ravages of time and the usual infirmities of years; but old age was not the immediate cause of his death. He was not stabled, but was running loose in an open yard with other horses, and received a kick from one of them in the flank; exposed without shelter to the inclemency of a northern winter, inflammation set in and he died. Before receiving the hurt which caused his death, he was perfectly sound, and entirely free from any description of blemish. His limbs were perfectly smooth, clean, freo from any swelling, and perfectly limber and supple.

Those persons who saw him in 1819 and 1820, describe his appearance as remarkably fresh and youthful. Age had not quenched his spirit, nor damped the ardor of his temper; years of severest labor had not sapped his vigor, nor broken his constitution; his eye was still bright, and his step firm and elastic.

However various may be the opinions different persons may entertain respecting the merits of the Justin Morgan, we doubt whether any horse can be instanced, 
in this or any other country, that has so strikingly im. pressed upon his descendants, to the fifth and sixth generations, his own striking and valuable characteristics; and it may be safely asserted that the stock of no horse ever bred in this country has proved so generally and largely profitable to the breeders of it. The raising of it has made the fortunes of hundreds of individuals, and added hundreds of thousands, if not millions of dollars, to the wealth of Vermont and New Elampshire. 


\section{CHAPTER VII.}

HISTORY AND DESCRIPTION OF THE STALLIONS SIRED BY THE JUSTIN MORGAN.

IT has frequently been asserted that but four stal. lions were kept for stock that were sired by the Tustin Morgan-namely, Bulrush, Sherman, Woodbury, and Revenge. The first we remember to have seen of this statement in print was in a published letter from $\mathrm{F}$. A. Weir, of Walpole, New Hampshire, that appeared in the "Albany Cultivator," vol. iil., page 19; but it may have been published before, and Mr. Weir may have only copied it. Since that time it has been printed in many different papers, and by some has been printed in a way that in effect endorses it, and has thus given such currency to it, that it is credited by a great many persons who have a pretty good knowledge of the history of Morgan horses, but do not happen to know of any other stallions kept from the Justin Morgan, except those above mentioned.

Thus they are readily led to believe the assertion, as it exactly coincides with their own knowledge on the subject; it does not stop short of what they know, and it goes no farther; but however generally this may have been believed, it is very certain that it is a mistake.

Nothing can be more natural than such an error, as, if it were true, it would be nearly if not quite impossi- 


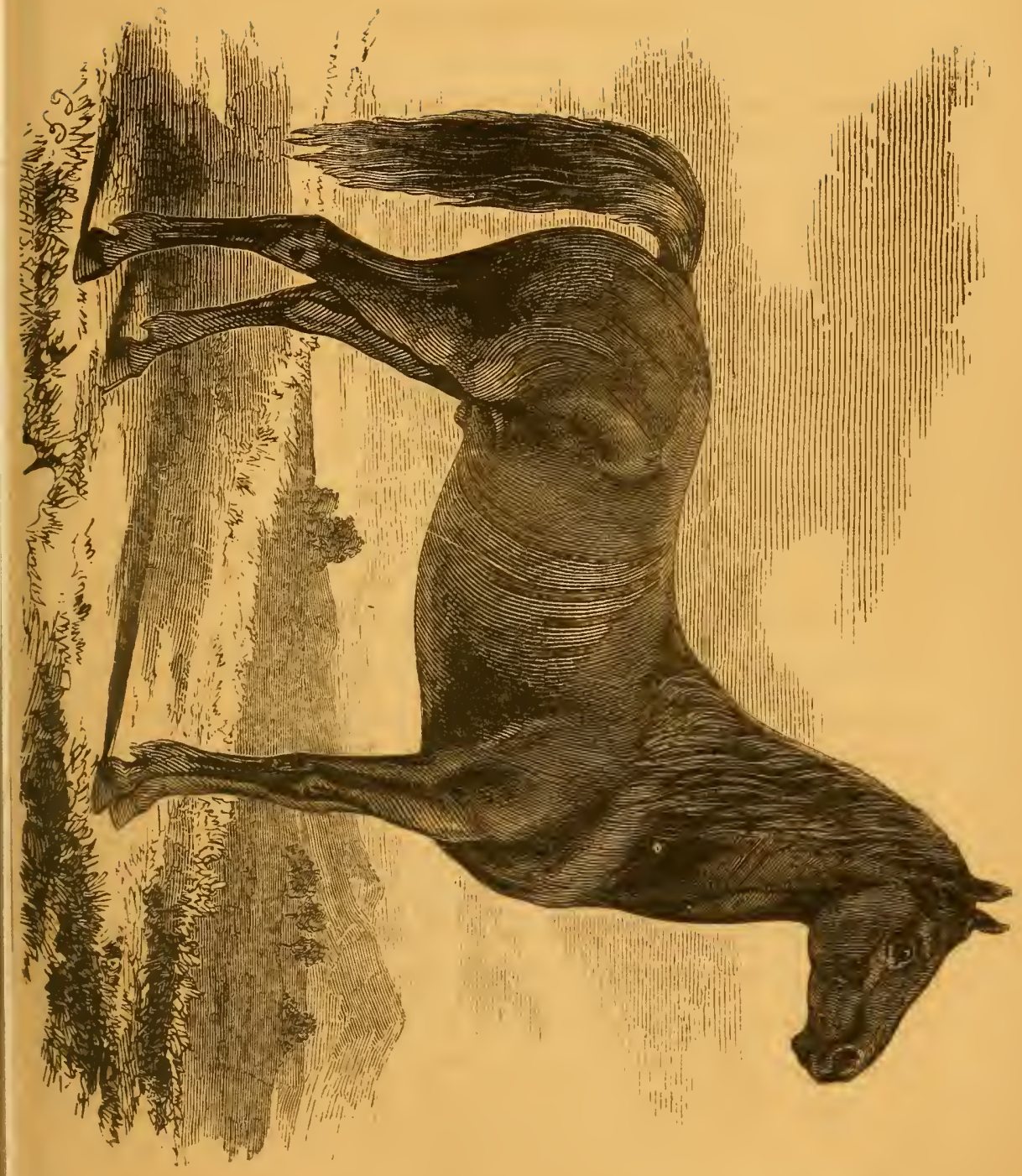



ble to prove it; for to do this, it is necessary to show what was the character, and history until they were grown, of all and each, of the colts sired by the Justin Morgan, through a period of twenty-five years, during which time he was owned by many different indivicluals, and kept at many different places. This we believe cannot be shown. It will at once be seen that the task of substantiating the pedigree of any given number of his colts, is an easy one, compared with that of demonstrating that there were no more. Therefore, while we shall describe the horses mentioned by $\mathrm{Mr}$. Weir, and also two others, we shall not venture the assertion that but six stallions were kept from the Justin Morgan; indeed, we do not believe that such was the fact; on the contrary, we have no doubt there were others, and we can only say, that we have been able to obtain no authentic account of more than six.

Between all the stallions left by him there was a very close and striking resemblance, in size, form, and general character, and they also bore equal resemblance to their sire; indeed, the power of transmitting to his progen $y$ his own form, constitution and temperament, was a very distinguishing trait of the Justin Morgan, and we believe no horse ever lived that possessed in a higher degree the power of stamping upon his offspring his own great leading characteristics.

Although it is not true that only four stallions were kept from the old horse, yet it is true that but four of them became celebrated, and of these four, one (Rovenge) derives his chief celebrity from the association of his name with those of Sherman, Voodbury, and 
Bulrush. Not that he nor the others we shall mention were necessarily less valuable than the three just named, but accidents of location and ownership will often prevent the most valuable animals from becom. ing well and favorably known.

The important features that characterized the Justin Morgan, his compactness of form, his high and generous spirit, combined with the most perfect gentleness and tractability; his bony, sinewy limbs, his lofty style, and easy but vigorous action, were strongly and strikingly impressed upon his offspring. Not only did his valuable qualities descend unimpaired to the next gen. ration, but apparently with little diminution to the second and third; and thus it is that where pains have been taken to select both sires and dams, possessing most of his blood and characteristics, young colts may now be found that closely resemble him in all important respects, except size, in which there has been a decided increase. We have stated our belicf that there were more than six horses kept as stallions, but we think it doubtful whether any stock can be traced to the Fenton horse, and but very little is descended from Revenge or the IIawkins horse.

The Hawkins horse was foaled in 1806 , or 1807 , the property of Mr. Melvin, of St. Johnsbury, Vt. He was sired by the Justin Morgan, his dam was a bay about fifteen hands high, of fine form and excellent action. She was sired by a black horse brought from Connecticut, and said to have been an imported thorough-bred racer, but it is not probable that he was, as we can find no record of any such importation near 
that time, or sufficiently near to render it probable that his dam could have been sired by such a horse.

When three years old, Mr. Melvin sold him to Olney Hawkins, a near neighbor. Hawkins was Captain of a troop, and he bought the colt to use as a parade horse. After keeping him five or six years, he sold him to his brother Stephen. Stephen kept him two years at St. Johnsbury, and then took him to Stanstead, Canada East. Here the horse remained a few years, and left some stock. From Stanstead he was taken to Upper Canada, but after this we are unable to trace him, and do not know where he was kept or when he died. He was a jet black, about fifteen hands high, not quite so compact as his sire, a little taller; and a very little heavier. His shoulders, back and loins, were excellent. He carried his head high, had a bold, resolute, and vigorous style of action, and was undoubtedly the fastest horse of the six; he was a smart trotter, and a good runner. His eye was a little fierce in its expression, and he was inclined to be cross, and not so tractable as the rest. He was one of the best acting and finest-looking horses under the saddle ever in the State.

The Fenton horse was foaled in 1808, the property of Richard Fenton, of St. Johnsbury, Vt. He was sired by the Justin Morgan; dam, a bay of unknown blood, nor can we learn any particulars of any importance respecting her form and style, except that she was well known in the neighborhood as an excellent animal. He was a beautiful blood bay, with black legs, mane, and tail; and about fourteen and a half hands high. He very closely resembled his sire, was very 
compact and muscular, had the same nervous and vig. orous action, the same lofty and fearless style, and we are inclined to think was one of the best, if not the best, of the Justin's colts. 'There were but few colts left by him, as when six years old he bit his owner quite severely, and he had him castrated. We cannot learn that any of his colts were kept as stallions.

Revenge was foaled in 1815, the property of Cyrus Moore, of Claremont, N. H. Sired by Justin Morgan. Dam, a light brown with a white stripe in the face, and white hind feet; she was a smart driver, but did not carry her head high; nor did she have a good gait, as she sometimes paced. Her sire is not known; her dam was bay with white in the face, and was owned by Mrr. Ball, of Unity, N. H. She piced a good deal, but was very smart. Nothing is known of her sire or dam, but she was called at that time a "Narragansett pacer."

Mr. Moore sold Revenge the autumn after he was two years old to Nehemiah Rice. Mr. Rice kept him two or three years, and sold him to a Mr. Tyler, and he kept him in the vicinity of Claremont until nine years old, when Mr. Moses Wheeler, of Claremont, purchased a half interest in him, and the next season purchased the other half. After keeping him one year, Mr. Wheeler sold him, and he passed through many different hands. He was kept near Connecticut river at Claremont, Croydon, Cornish, Wethersfield, and intermediate points. In 1835 or 1836 , he became the property of Edwin Billings, of Claremont, who kept him until he died. In April, 1837, Mr. Billings drovo 
him to Chester, Vt., intending to go to the western part of the State, but here the horse was taken sick and died suddenly.

Revenge was a dark bay, or light brown. In the spring after shedding his coat he might almost be called a black, but in the winter he was often called a bay; he was about fourteen and a half hands high, and weighed fully one thousand pounds; he had less action than either Woodbury or Sherman ; but he had a very closeknit form, with excellent back, loins, hips, and limbs; his chest and shoulders were not so fine as some of the others, nor did he have a very smooth, easy gait, but he never paced nor hitched. He had plenty of life, great endurance, and, as one of his owners said to us, "he was an ugly customer to get away from on the road." His stock were dark bay or brown, and occasionally chesnut. They had good size, were strong, hardy, and enduring; generally free drivers, but had not as easy action nor as good style as the stock from the others; and some of them would both pace and trot. When a colt, Revenge was frightened by the breaking of some portion of his harness or carriage, and ran away. From the effects of this fright he never fully recovered, and if driven single would pull hard when a little excited, but we have not heard of his ever running, except on the occasion just mentioned. He was perfectly sound.

Of his colts, we have been able to learn of but one that was kept a stallion. It was a very dark chestnut, about fifteen hands high, and weighed about ten hundred and fifty pounds. In 1853 he was owned by Mr. John Clark, at Dunham, Canada East, and we think w 
raised by him at Windsor, Vt., where he formerly lived. This horse had an excellent, open gait, fine style, and was called the fastest horse in his neighborhood.

As it has been stated that the dam of Revenge was white, we have taken much pains to obtain the most reliable information upon this point, and have visited. several persons who knew her well for years, and knew the colt "Revenge" from the time he was foaled until he died, and without a single exception they describe her color as we have stated it.

Sherman was foaled in 1808 or 1809 , the property of James Sherman, of Lyndon, Vt. It has been said, that Sherman was foaled in 1810, and it has also been said that he was foaled in 1811. It is not at all surprising that his age should be understated by a year or two, as the horse who lives to be more than ten years old, loses nothing so easily as one or two years of his age.

Our reasons for stating his age as we have, are these: Mr. George Sherman, son of James Sherman, informs us that he has now been married forty-five years, and that in the summer after he was married, his father let him take the horse, then a colt, to keep and use. Mr. Sherman's wife also well recollects the above facts, but neither of them can say positively whether the colt was two or three years old, though both of them think he was three; and from the fact that Mr. Sherman used him a good deal that summer, it seems most probable that such was his age. Sherman was sired by the Justin. With regard to the blood of his dam, much has been said and a good deal written, but we think little is actually known. 
Mr. George Sherman says, his father brought the mare from Cranston, Rhode Island, to Lyudon, Vermont; that she was a ehestnut, of good size, high spirited, and an "elegant" animal; "we called her of Spanish breed."

The late Hon. Epaphras Seymour, of Brattleboro', Tt., a gentleman of fortune and high standing, and passionately fond of horses, spent much time in endearoring to ascertain the pedigree and early history of the Justin Morgan and his descendants. Among the memorandums left by him, now in possession of the Hon. F. Holbrook, which the latter gentleman has kindly permitted us to examine, we find the following: "Miatthew Allen, of Guildhall, now seventy years old or over, informs me that James Sherman and himself came from Rhode Island to St. Johnsbury, in 1799; before they left, Mr. John Brown, of Providence, gave Mr. Sherman an imported English mare, of great beauty, a fine saddle-mare, and so used by his daughters (she was then spavined); she was a mahogany brown, 15 1-2 hands high, delicate makc." Mr. Allen goes on to state, that this mare was the dam of the Sherman.

Mr. S. C. Gibbs, of Littleton, New Hampshire, who purchased the horse of $\mathrm{Mr}$. James Sherman, gives the following aceount of the dam: "She was bought at the South (I think in Virginia), by Mr. John Sherman, of Providence, Rhode Island, who had friends in that State. He purchased her for her beauty and speed. Soon after he returned with her, she unfortunately slipped her hip. He then gave her to his brother James, of Lyndon." 
It has also been said that the dam was long owned by Nicholas Brown, of Providence, Rhode Island, one of the well-known firm of Brown \& Ives, formerly a large importing house. Mr. George Sherman says, his father bought the mare of Doctor Fiske, of Cranston, Rhode Island. It is of little consequence which of these accounts is correct, as none of them undertake to give her pedigree. If either had made an attempt to do this, the question would have possessed more interest and some importance. It certainly concerns us little to know, in what manner, or from whom, Mr. Sherman obtained her, if we cannot go beyond that and Jearn something of her pedigree. We are inclined to think the statement of Mr. Sherman entitled to the most credit, because we think his means of knowing the facts of which he speaks were much superior to the others. His father used the horse several years, valued him highly, and was often interrogated as to the dam. George must have often heard his father describe the circumstances under which he obtained her; they must have been well known in the family, and the constantly increasing fame of the horse would keep alive in its members the recollection of them, as related by James Sherman. Mr. George Sherman is a man, whose character for the most unwavering honesty has been long and thoroughly established, where he is known.

Whoever may have bred the mare, and whether of Spanish or English descent, it is ccrtain she was a fine animal. She was chestnut, with three white feet, and a white stripe in the face. Her head was good, ears small, neck light and rather long; not very compactly formed and never "carried much flesh." She carried 
her head high, was a spirited traveller, and an excellent saddle beast. She was very pleasant tempered, and worked kindly in all places.

"Sherman" was a bright chestnut, about thirteen and three-quarters hands high, and weighed nine hundred and twenty-five pounds. His off hind-leg was white f:or the foot half way to the hock, and he had a small white stripe in the face; his head was lean and well shaped, ears small and fine, eyes inclined to be small, but full, prominent and lively; his legs had some long hairs upon the back-side, but were broad, flat and sinewy. He had a capital chest, with the breast-bone very prominent; the shoulders were large and well placed, the neck excellent, the mane and tail full, but not remarkably heavy. His hips were long and deep, the loins broad and muscular, but he was a little hollow or "sway-backed ;" still, no suspicion of a weak back could attach to him, or he would have broken down under the rough treatment he received in early life. When four years old, Mr. Sherman put him to hard work, and though for about two months in the spring of each year he worked but little, yet the remainder of the year his labor was very severe. Mr. Sherman was a hard working man, and animals under his charge had few opportunities to rest. Most of the year the horse was kept constantly at work on the farm, much of which he helped to "clear up." In the winter, Mr. Sherman usually ran a team steadily from Lyndon, Vermont, to Portland, Maine. For several years, this team consisted of this horse, and a half brother, sired by the Justin Morgan, a year older and a little larger than Sherman.

Mr. Sherman was not a man to be outdone at drawing 
or driving, and he was always ready to match his team against any he met, either to draw or run, for a trifling wager. IIis "little tear" became famous at every inn from Lyndon to Portland, and after a time the teamsters that knew them were afraid to match horses of any size against them. In the spring, when the sleighing became poor, the men who had been companions through the winter in the severe labor of team. ing across the country, would often congregate at the village taverns, to spin yarns of their simple but rough adventures, engage in wrestling, running foot and horse races, drawing matches, and many games invented to test the speed or strength of either men or horses. In addition to these attractions, the prospect of a social glass of "Old Santa Cruz," may have had some influence in drawing together the people collected on these occasions, for it was at that time considered a pleasant beverage, and it was not generally known to be a subtle poison. Certain it is that these games were well attended, and were conducted with much spirit. Drawing matches were at that time very common. At Lyndon, the usual way of drawing was to attach a horse to a sled, fill it with men, and draw the load up a steep hill just north of the tavern. "When each his utmost strength had shown," Sherman would add a small boy to the largest load and commence the ascent, well satisfied if he could gain two or three feet at a pull, for nothing discouraged his horse, and it was difficult to load him so that he could not more a little. Theso facts are perfectly well known to many persons now living at Lyndon, and we mention them, not from any intrinsic interest they may possess, but having 
said that Sherman was slightly hollow-backed, we thought it necessary to show, that if so, his back was by no means weak.

Such was the hind of service to which Mr. Sherman put his horse from the time he was four years old until he was about ten, when he sold him to Stephen C. Gibbs, of Littleton, New Hampshire, in 1819. Mr. Gibbs kept him one year, and sold him to John Buckminster, of Danville, Vermont, but Mr. Gibbs had charge of him two years longer. After this, he was kept at Danville and vicinity until 1829 , when he was purchased of Mr. Buckminster by Mr. John Bellows, of Lancaster, N. IT. The summer of 1829 he was kept at Littleton, N. II., in charge of Stephen C. Gibbs; in 1830 he was kept at Dover and vicinity; in 1831 he was at Col. Jaques' Ten Hills Farm, Charlestown, Mass.; in 1832 he was at Dover, and Durham, N.H.; in 1833 he was kept at Lancaster, N. II. ; and in 1831, at Dover and vicinity. He died at Mr. Bellows' stable, in Laneaster, the 9 th of January, 1835. The cause of his death is unknown. He was left at ten o'clock in the morning apparently perfectly well, and at one o'clock in the afternoon was found dead.

With the exception of some slight indications of age, Le was apparently as free from every species of blemish or infirmity, the morning of the day he died, as when he was foaled. His skin has been preserved and stuffed, and may still be seen at the stable of Mr. George Bellows, at Lancaster, N. II.

Sherman had not so bold and resolute a style of action, and was not so nervous and high tempered as Woodbury; nor was he, in the language of the stable, 
so well "finished up;" but he was more tractable, was exceedingly spirited, and a keen, rapid driver-possessed great powers of endurance, a free and noble spirit that needed ncither whip nor spur, and courage that never flagged.

Woodbury, sometimes called the Burbank horse, and known in Windsor county as the Walker horse, was foaled the latter part of May, 1816, the property of Lyman Wight, of Tunbridge, Vt. It has been said, that he was raised by a "IIr. White," but this is a mistake that would easily occur; the pronunciation of the two names is almost the same, and the latter being much more eommonly used, the name has been misunderstood. Woodbury was sired by the Justin Morgan. Of the blood of his clam, we are unable to learn anything. At the time the colt was foaled, Mr. Lyman Wight was a young man, about eighteen years old, and the dam belonged to his father, William Wight, who had loaned her to his son for the purpose of raising a colt. She was five years old when the colt was born. Mr. Wight purchased her the year before, of a Maj. John Moulton, of Bethel, Vt., who brought her into that town. She was large, being over fifteen hands high, and weighed about eleven hundred pounds; she was of a deep bay color, with black legs, mane and tail, a small white spot in the forehead, and no other marks. She was not very compactly made, and was rather flatribbed; but she had an excellent chest, fine shoulders and hips, and excellent limbs. Fier head was very fine, ears good, and mane and tail beautiful. She carried her head high, was a very free, spirited driver, and was 
called fast at that time. She both paced and trotted, generally starting in the former gait, and after going a short distance changing it for a trot. When trotting, she made a fine appearance, and going fast attracted much attention. Shẹ was a very fast walker. The autumn after the colt was foaled, about the usual time of weaning, Mr. Wight sold him to David Woodbury, of Bethel, Vt., for fifty dollars. Mr. Woodbury kept him until grown, and sold him to his brother John.

John had a taste for good horses, and in his hands the horse began to be a little known. He kept him at Bethel and the neighboring towns a few years, and sold him to Ebenezer Parkhurst, who kept him in the same neighborhood until March, 1826, when he sold him to Simon Smith and Wm. Walker, of Hartland, Vt., for five hundred dollars. Soon after this, Messrs. Smith and Walker dissolved partnership, Mr. Walker keeping Woodbury. Mr. Walker had a passion for horses; he saw and appreciated the remarkable features of the Justin Morgan and his stock, and took much pains to bring them into notice; but like many a pioneer in a new business, he could not make it pay, and being a man of small means, he was compelled to "sacrifice his horse," as he terms it, "for the insignifisant sum of four liundred dollars," and sold him to Peter Burbank, Esc., of Newbury, Tt. Mr. Burbank was a lawyer, and not a farmer or brecder, but he was fond of horses and had a discriminating eye for their good points, and having seen the Woodbury at Keene, $\mathrm{N}$. H., he (in his own words) "fell in love with him at first sight." Fearing to trust to his own judgment alone, he consulted Jesse Johnson, of Bradford, Vt., a 
gentleman who not only possesses excellent taste as to the proper style and general figure of a fine horse, but has also that close, critical eye, that seems almost at a glance to take in all the minute defects of form that a more careless observer might fail to discover. Mr. Jolnson did not fail to perceive the extraordinary merits of the horse, and advised Mr. Burbank to purchase him, which he did the 20th of May, 1830. From this time until 1836, he was taken charge of by Jesse Johnson and Brothers, and kept at their place in Bradford, Vt., during the winter and latter part of the summer and autumn of each year, and one or two years. during all the seasons. During the years 1830 and 1831, he remained at their stable at Bradford. The season of 1832, he was kept at Keene, N. H.; the season of 1833 , he was kept at Burlington, Vt., and the seasons of 1835 and 1836, he was kept at Bradford and vicinity. In September, 1836, Mr. Burbank having died, the administrators of his estate sold him to Norman Baglee, of Alabama, who took him to Gainesville, in that State, where he died in 1838, bcing twenty-two years old.

Woodbury was fourteen and three-quarters hands high, and weighed from nine hundred and eighty-eight pounds to ten hundred and forty pounds; he was weighed several times, and these two statements of his weight, at different times, are the extremes. Many persons who have frequently seen him weighed, say they never knew him weigh more than ten hundred and thirty, nor less than ten hundred and fifteen pounds. He was a dark, rich chestnut; his off hind-leg was white from the foot half way to the hock, and he had a white stripe in his face, beginning at the edge of the 
upper-lip, filling the space between the nostrils, and extending more than half way to his eyes. His mane was not very thick, or long, and was lighter than either of the others, still it was full. His tail was cut off when a colt, and left about ten inches long; the hair was very full, and curly; both mane and tail were about the same color as his body. The hair on the body was fine, short and soft. He was close and compactly built, with heavy quarters and deep flanks; his chest was good and the shoulders finely shaped; he had a short back, and broad, sinewy loins. His legs had some long hairs on the back-side, but were well shaped, somewhat larger than Sherman's and not so large as Bulrush's. His head was small and lean, with a fine, firm muzzle, the nostrils very large and full, face straight, very wide between the eyes, which were dark hazel, very large and prominent, and showed no white around the edge of the lid. His ears were small and fine, but rather short, and set somewhat wider apart than many would consider consistent with perfect beauty. His style of action was bold and resolute, and his temperament was so nervous, that when taken out with a bridle it was almost impossible to keep him still. He was a good driver and appeared well in harness, but he appeared to the best advantage under the saddle. Militia Colonels and Generals were eager to ride him, and no "musters" or reviews could pass without his being seen; in his case, to be seen was to be admired. His disposition was pleasant and playful.

As has been said, he was taken to Gainesville, Ala., in the autumn of 1836 , being then twenty years old. He was shipped from Boston, on board a small sailing 
vessel; he suffered much from the long and stormy passage, and never fully recovered from the effects of it. It is altogether likely that the climate and food did not agree with him, for neither was such as he had been accustomed to; however this may be, it is certain he continued to fail until he died in 1838. Woodbury was the largest of these horses, and possessed in a greater degree the bold, fearless and showy style of their sire; he was more nervous, and less tractable than Sherman, better under the saddle, not so pleasant in harness, and we are inclined to think hardly as good a roadster. His form was more symmetrical than either of the others; his breast was not so full and prominent as Sherman's; he was deeper in the flanks and better quartered. No horse ever had less fear. Martial music only roused him, the firing of guns in no way disturbed him, waving flags and gay uniforms seemed hardly able to attract from him a single glance, and he moved about as if he was himself the principal object of attraction and the cause of all the attending excitement and display.

Bulrush was foaled in 1812 or 1813 . Of this we think there can be no reasonable doubt, although it has been stated that he was foaled in 1816. We have consulted persons who owned both Bulrush and Woodbury, and they all agree that Bulrush was the oldest of the two. Now, there is no question but that Woodbury was foaled in 1816, and if Bulrush was older, it is altogether probable that he was more than one year older, for the Justin Morgan was taken to Claremont early in the spring of 1814, and remained there one year, and the 

dam of Bulrush was owned in Randolph, Vt., the year he was sired, so that in the absence of any other tes. timony, we might very reasonably conclude that he was not foaled later than 1814; but the testimony of Chester Belknap is clear and direct, that he was foaled in 1812. Mr. Belknap was married in 1819; his father, who raised the horse, owned him at that time, and soon after sold him to Abel Densmore, of Chelsea, Vt.; he was then seven years old. This statement of Mr. Belknap's, in relation to the age of Bulrush, is confirmed by many persons who knew him well, and there can hardly be a doubt that it is correct. The blood of the dam of Bulrush is unknown. She was a dark bay, with black legs, and heavy black mane and tail; she was low and compact, had heavy limbs, with large joints, neck rather long, a good head, but did not carry it up very well; she was a sharp trotter, but was not a very spirited driver; she was said to be, and had the appearance of being, part French. She was owned by Mr. Moses Belknap, of Randolph, Vt., at the time Bulrush was sired. Mr. Belknap obtained her of a Mr. Boutwell, a teamster from Montpelier, Vt., who worked her in a six-horse team, hauling merchandise and produce between Montpelier and Boston. She was a very rugged, hardy, enduring animal, but Mr. Boutwell thought her too small for his business, and he exchanged her with Mr. Belknap for a larger horse. She weighed about ten hundred pounds. Mr. Belknap sold her late in the winter, when in foal by Justin Morgan, to Ziba Gifford, Esq., of Tunbridge, Vt., Mr. Gifford to keep the colt until four months old and return it to Mr. Belknap, or pay thir- 
teen dollars more and keep it. Mr. Gifford preferred to return the colt and did so.

Mr. Belknap kept Bulrush in Tunbridge and vicinity, until 1819, when he sold him to Abel Densmore, of Chelsea, Vt. Mr. Densmore sold him to Darius Sprague, of Pandolph, Vt., who sold him Narch Stb, 1826, to Messrs. Simon Smith and William Walker, of Hartland, Vt., for three hundred and fifty dollars. They kept him at Hartland and vicinity, until they dissolved partnership in 1829, when Mr. Smith took Bulrush to Maidstone, Vt. He liept him one year at Chelsea and two years in the State of Maine, and in 1833 sold him to Jesse Johnson and Brothers, of Bradford, Vt. The season of 1833 he was kept at Bradford, Vt., and Bath, N. H. ; the season of $183 \pm$ at Keene, N. H.; the season of 1835; at Lyme, N. H., and Bradford, Vt.; and the season of 1836 , at Burlington, Vt. During the winter of 1836 and 1837, the Messrs. Johnson sold him to Messrs. Blake and Foss, of Chelsca, Vt. who kept him in that town until 1842, when they sold him to Lewis Jenkins, of Fairlee, Vt., who kept him at Fairlee until he sold him to F. A. Weir, of Walpole N. H., who kept him until he died in 1818.

Bulrush was a dark bay, with a few white hairs in his forehead, and no other marks; his legs, mane and tail were black, and his mane and tail were very heavy -the former came down nearly to his knees, and his foretop came down to his nose; his tail was cut off when young and left about nine or ten inches long; his legs were large and had some long hair, were closejointed, broad, flat, and exhibited a more striking de. 
velopment of muscle than either Woodbury's or Sherman's; his back was not so short as either of the others', but it was very broad, and he was freer from any im. putation of sway-back than any of his brothers, though towards the close of his life he indeed fell away in his loins, as is always the case in old stallions. His hips were very good, but not so long as Sherman's, and he was not so well quartered as Woodbury, but he was deeper in the chest than either of them; his shoulders were thicker and not so well placed, and his head and neck were not so well set up. He was not so proud, bold and lofty in his carriage as Woodbury, and he had not Sherman's short, nervous step, and tractable but high-spirited temper; but he was a sharp, quick driver, and a faster trotter than either of them. He was a little inclined to be cross, but was not fierce, or in any respect unmanageable; on the contrary, he was very kind in harness, always working pleasantly wherever put. His most remarkable characteristic was his power of endurance. For this, we think it is generally admitted, he had no rival; and his extraordinary lastingness has become proverbial where he was known. His stock bear a strong resemblance to him, and are very numerous; are mostly dark bay without marks, never sorrel or light chestnut; occasionally a dark gray, from a white mare, may ke found. Bulrush was about fourteen hands high, and weighed about one thousand pounds.

Bulrush, Sherman, and Woodbury, were treated very much alike. Until after ten ycars old, each of them was employed most of the time at the ordinary team-work of a farm, and at no period of their lives did 
they have any more care than the common horses of the country; and never had much knowledge of thick blankets and warm stables, but were early inured to the labor and hardship, fatigue and exposure, incident to a new and mountainous country and a cold climate. It is not improbable that the cold, dry atmosphere, and pure water of our mountains, has contributed as much as the rich pastures of our valleys to the stoutness, courage and lastingness of our horses.

We have thus slightly sketched the more obvious distinctions and general characteristics of these celebrated sons of the original or Justin Morgan. While they differed in the particulars we have herein set forth, (which difference was rather in the degree, than the nature of their qualities, they all possessed the great and striking features of their distinguished sire. The same compactness of form, great muscular development, hardy, rugged constitution, docility and tractableness, short, easy, rapid step, cager ambition and lofty courage, so remarkable in him, were found in each of them in a high degree. Through these noble channels, the blood of the Justin Morgan has been poured profusely into the hitherto hardy stock of Vermont, conveying not only the very form of the great original, but all his unrivalled vigor, grace, and ease of motion, combined with his docility and matchless courage. 


\section{CHAPTER VIII.}

AENFRAL DESCRIPTION OF THE DIFFERENT FAMILIES AND THEIR DISTINGUISHING CHARACTERISTICS.

ANY disinterested reader of the articles that have at various times appeared in the sporting and agricultural magazines of the country, written by persons interested in the different families of thorough-breds, cannot fail to have noticed that a great diversity of opinion exists among them, as to the relative value of the stock of these different families. They may agree perfectly as to the unrivalled excellence of some common ancestor, but differ widely as to the relative merits of the different fimilies descended from him. They will unite in an effort to make it appear that Diomed was the finest horse ever imported to this country; but, guided by different tastes or diverse interests, will make a corresponding effort to advance the claims of particular families descended from him. One asserts that Sir Archy was far the most worthy of his sons, and points exultingly to the unrivalled speed and beauty of Sir Henry; while another with equal confidence sustains the claims of Duroc to this distinction, and triumphantly refers to the unequalled power and endurance of Eclipse. Again, another interested, perhaps, in other strains of blood says: Sir Henry was too small, and believes Eclipse derived his lasting endurance from Messenger or Gim crack. 
So it is with persons interested in different families descended from the Justin Morgan. They find no difficulty in agreeing as to his merit, but do not at all agree as to the merit of his celebrated sons. Some, while they manifest a decided preference to one branch do not deny that the others possess some valuable qualities. While others, less candid, or more strongly influenced by interest, deny that any other family save that to which their own animals belong is deserving of any notice. We do not pretend. that this is by any means universal-on the contrary, we are well aware that there are many candid, thoughtful, and intelligent breeders, who, although breeding from but one family, yet freely admit that while they have a preference for one branch, they cannot deny that either of the others may posiess qualities equally valuable. It is not to be supposed that these families were exactly alike. We have in a former chapter endeavored to point out the points in which the heads of these families differed from one another, so is there a noticeable difference in their descendants.

It does not necessarily follow that because there is a noticeable difference between two animals, there must be a corresponding difference in value; for we cannot lay down abstract rules so that the business for which the horse is wanted being given, we may determine his value, by any application of avoirdupois measure or Gunter's rule. Two horses may be so nearly equal in value that the very best horsemen may honestly differ in choosing between them; and yet they may be so dissimilar that a child can mark the difference.

Besides, there are many points connected with what 
fanciers call the "finish" of a horse, that are as exclusive matter's of taste as the style of a lady's dresssuch as the expression of the eye, the color, the relative proportion of bone and muscle, the temperament, style of movement, \&e.

Should any one succeed in defining clearly what he considered superlative excellence in these particularshe would only have succeeded in publishing his own taste in the matter, instead of establishing any general rule by which others would be guided. For these reasons, we cannot be too cautious in deciding upon the relative value of different animals closely resembling each other in all their most striking and leading characteristics. Therefore, we shall not attempt to decide which of these families possesses the most valuable qualities, but shall content ourselves with endeavoring to show the principal points in which they differ.

There can be saik to be but three distinct families of Morgan horses, namely, the Bulrush, Sherman and Woodbury. For although the Hawkins horse left some stock about Derby and Stanstead, and Revenge some in the vicinity of Claremont, $N$. H., yet there are not now a sufficient number of animals living desceuded from these stallions to entitle them to be classed as distinct families. The Bulrush family are most numerous in that portion of the States of Vermont and New Hampshire lying on Connecticut river, between Windsor and Newbury. They are almost invariably deep bays or browns, with black legs, manes and tails; in this respect they differ from the other families, and also in their general (we might almost say universal) freedom from any marks, such as white feet or white spots 
in the face. They have large limbs, wide, flat and muscular, sometimes inclined to be a little coarse, but the joints are good, and the whole limb very large in proportion to the size of the animal. We do not recollect ever seeing a spavin or a ringbone on a Bulrush horse. They exhibit great development of múscle, and in point of size are fully equal to the average of Morgans. They have not so bright, lively and intelligent eyes as the other families, though the eye is by no means dull or stupid. They do not carry their heads as high, nor have they as bold and eager an expression as the Woodburys, and they have not as graceful and easy motion as the Shermans, but for lastingness and power of endurance, we believe they have no rivals in this, or any other country, among Morgan's or any other breed. There is really some ground for the assertion a jockey acquaintance once made to us, that " a smart active boy would wear out a wrought-iron rocking-pony, sooner than a grown up man could break down the constitution of a Bulrush horse." In addition to this power of endurance; they are generally sharp, keen drivers, and many of them are fast. They are not excitable, never fret upon the road; but are busy, inclustrious workers. Some of this family have considerable long hair upon the legs, and others are entirely free from it; most of them have very heavy manes and tails.

The Woodbury family are found most numerous in the central part of the State of Vermont. There are also many along the Connecticut River, between Brattleboro' and Newbury. The founders of this and of the Bulrush families were bred close together and remained near each other most of their lives; hence their 
descendants are found in the same vicinity. The average size of the Woodburys, we believe to be greater than either of the other families. They are deeper in the flauks, with heavier quarters, but not so heavy in the chest. Some are inclined to be hollow-backed, and in this respect differ from the Bulrushes. They have an exceedingly bold, lofty and resolute style of action, and are overflowing with spirit and nervous energy. They are generally very tractable, but eager and restless; are full of ambition and cat-like activity, that makes them favorite horses for parade. Their prevailing color is ehestnut or bay, often with a white stripe or star in the face, and white on one or both of the hindfeet. Only a few of this family have any long hair on the legs above the fetlocks, and they do not generally have as heavy manes and tails as the other families. They have a shorter gait than the Bulrushes, and are spirited, pleasant drivers. The limbs, with the exception that they are freer from long hairs, closely resemble the limbs of the Shermans, being not so large as the limbs of the Bulrushes. They have generally a softer coat than either of the other families.

The Woodburys have the largest, most prominent and brightest eyes of any of the Morgans. The forehead is also very broad and the muzzle good, but in some of them the jowls are not so well shaped as the others.

The Shermans are most numerous in that part of the State between Newbury and the Canada line, and the neighboring parts of New Hampshire, about Brownington, Derby, and Stanstead, and in Addison county. We think the Shermans are gencrally smaller than the 
Woodburys. They are more inclined to be hollow. backed-but their backs are very short, with wide, full and exceedingly muscular loins, so that although some of them may be called hollow-backed, yet we venture to say that none of them were ever knowin to have weak backs. They are deeper in the chest, with a more prominent breast bone, and lighter quarters than the Woodburys. Their limbs are superlatively good; and although they oftener have more long hair upon them than the Woodburys, yet underneath this hair will invariably be found a hard, sinewy limb, free from windgalls or any other unsoundness.

They have a shorter gait than the Bulrushes, and do not raise their feet as high in travelling.

They have not so bold, eager, and commanding a style of action as the Woodburys; but we think they have a better temper for driving, and full as much spirit; and nothing can exceed their courage on the road. They have a more rapid walk than either of the other families, and an exceedingly short, nervous step that creeps up the 'longest hills at a rate that would surprise a person unacquainted with them. They are easily broken to harness, and, though spirited, are very gentle and tractable, and may be easily taught to stand without fastening wherever left. A little circumstance that came under our own observation "will illustrate this. Sitting one evening in the hotel at St. Johnsbury, Vt., and talking with a conductor of the Passumpsic Pailroad, we said to him that we understood he had a very smart little mare of the Sherman family. He said he had, that she was out in the street before a cutter, and as the night was not very dark, proposed that we should 
go out and look at her. We went out upon the steps, but did not notice any animal about the premises. However, our friend commenced calling "Nelly! Nelly! here Nelly!" and sure enough the mare, who was standing on the opposite side of the street, and some six or seven rods from us, pricked up her ears, and immediately came over to the place where we were standing. We jumped into the sleigh and took a turn down the street, the mare proving herself as spirited as she was gentle.

The Shermans, like the Woodburys, are generally chestnut or bay, chestnut being the prevailing color, light chestnut being more common in this than the other families. A white stripe or star in the fice, and white hind feet, are very common.

We think the Shermans have the best action in harness, and the Woodburys the best action under the saddle, or moving without saddle or harness at the end of a bridle rein. Persons unaccustomed to use horses except under the saddle may not understand in what this difference consists, and we will endeavor to explain. To appear well upon a parade or fair ground, under the saddle, or led, the horse must have a good figure, with abundance of muscle, the head must be carried high, and he must be overflowing with life and nervous energy, that keeps him constantly in graceful and active motion. His movements are comparatively unrestrained. If he champs his bit, and tosses his mane with excitement, it will not injure his appearance, provided he exhibits a pleasant temper, and yields cheerfully and readily to the authority of his master. To appear well in harness, the horse must have a 
figure equally good, the same muscular development, and exhibit a ligh spirit, but he must have less eagerness, he must have submitted himself perfectly to the control of his driver. He must carry his head high, but must keep it constantly and easily in that position; he must move directly forward without any prancing or sidelong motion, and must move invariably in a walk or trot; in short, he must be a perfect and beautiful machine, guided by a touch, and controlled by a word. If touched with the whip, he must not bound with fright or ill temper, nor if possessed of the right temper will he fail to notice it-on the contrary, he will not soon forget it, and the driver who ventures to administer the blow will find ample evidence, in the increased and steady pull upon the reins, that it did not pass unnoticed. While thus moving like some beautiful machine, and submitting wholly to control, every movement must appear perfectly easy and natural, and there should be no appearance of restraint, just as all the attitudes and gestures of the finished actor appear spontaneous and natural, when in fact they are all studicd and artificial.

Black Hawk and Green Mountain (in the list of pedigrees he is called Green Mountain second, to distinguish him from an older horse of the same name) will illustrate our meaning: they are both fine specimens of the race, and are both widely and favorably known. Aside from his speed, the reputation of Black Hawk as an elegant driving horse is too thoroughly established to be in any way increased or diminished, by what we might say of him, and we refer to him only to illustrate our meaning. He comes nearer to 
our beau ideal of a perfect driving horse than any other animal we have ever seen. Possessed of abundance of spirit and life, there is also manifest a quietness and evenness of temper that makes him under all circumstances perfectly controllable; his step is nervous and elastic, but no unnecessary steps are taken. His style of movement is bold and fearless, while every motion is instinct with grace. But he has not that exuberant, overflowing, and irrepressible spirit of action that prevents him from being a moment at rest. Green Mountain is rarely if ever exhibited in harness, and properly enough, for although we have no doubt he is a fine driving horse, yet it is not in that capacity he appears to the best advantige. While under the saddle, or led by a bridle rein, in style of movement-in muscular development-in spirit and action-he need not fear comparison with any horse living. There is a boldness in his style, a fire in his eye, and an unceas. ing play to every muscle, that once seen by a person having any taste for a horse will never be forgotten. In boldness and gracefulness of style he resembles Grey Eagle of Kentucky, but has more fire in his eye, and is more unceasing in his action.

In drawing a comparison between the different families, and in endeavoring to point out those qualities which as families they possess in different degrees, it will be readily seen that we can lay down no general rules of this kind that will not have many exceptions; for in many respects these distinctions are so slight that they are often unnoticed, and the fact that the different families arc now being crossed with each 
other, is gradually effacing these distinctions. This crossing of the different families, if properly conducted, will, we believe, be of great benefit, and tend much to the improvement of the race, and should be fostered and encouraged by our agricultural societies. There has in some instances been manifested a disposition among persons owning stock of one of these families, to endeavor to establish the reputation of their own animals by denying the good qualities of their neighbors. This is a weakness that is not confined to Vermont, but we suppose must be found everywhere so long as human nature is frail: still, however common it may be, it is none the less a weakness. We say "weakness," for, although slaudering a neighbor's stock is a gross wrong, yet is it pre-eminently a weakness, and no really shrewd and intelligent man will ever be guilty of it, for it is always sure to re-act with twofold force upon him who resorts to it.

The breeder whose stock has so little merit of its own that it must be bolstered up by detracting something from his neighbors, we earnestly exhort to sell out at once, and purchase some that can rely solely upon its own merits for distinction; for, if it is wanting in merit, no art can bring it into repute, and keep it long in favor; and, if it is superior, be satisfied with exhibiting it to the public, and rest assured that there will not be wanting men with sagacity enough to see and appreciate it. 
$-$

1

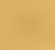




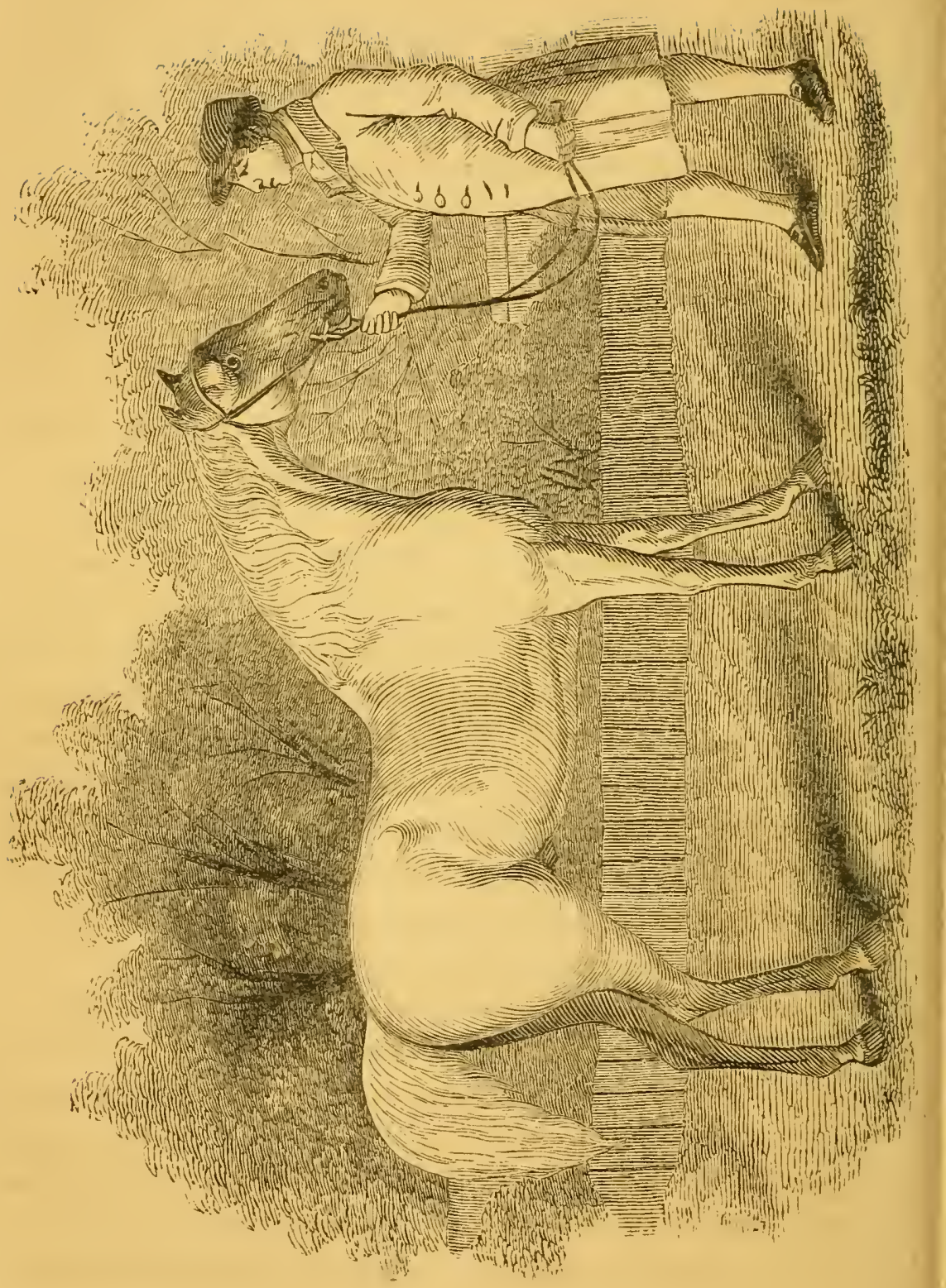




\section{CHAPTER IX.}

PRESENT CONDIXION OF THIS STOCK IN VERNONT.

To understand well the present condition of this breed of horses, it will be necessary to glance at the original horse and his immediate descendants, and contrast them with stallions of repute of that blood of the present day. For although such a comparison in no way assists us to determine the height, weight, or any other qualities of the breed as they now exist, yet it is indispensably necessary to enable us to ascertain whether any change has taken place in their general character, and if so, what that change is.

From a careful consideration of all the most reliable accounts of the Justin Morgan, he was about fourteen hands high, and his weight, in good condition, not far from nine hundred and fifty pounds.

His weight is only obtained by estimate, as there is no account of his having been weighed; and, as weighing live animals was by no means common at that day, it is highly probable that it was never accurately ascertained. His height we undoubtedly have more nearly exact, for horsemen who knew hin are much better agreed as to that, and they would judge much more accurately of his height from the fact that height was the usual measure of size at that time.

In a previous chapter we have described the most celebrated animals sired by him, and those from which 
our present stock is entirely derived. From a com. parison of the height and weight of these animals, namely, the Sherman, Bulrush, and Woodbury, with the sire, we shall see that they were both taller and heavier.

Between these three horses there was a very striking resemblance in all their leading characteristics, as we have already seen; and each exhibited in a high degree those qualities that have given such eelebrity to their sire. All had the compact form, the wide bony legs, great nervous energy, vigorous health and iron constitution, that enabled them to endure for years the severest labor upon scanty feed, and with littie care, not only without breaking down, but without receiving the slightest injury. At the age of twenty we see them exhibiting constitutions as unimpaired, limbs as free from any sort of blemish, and almost as supple and as sinewy as when first broken to harness, and at even a later date showing upon all occasions the same high courage and invincible spirit that was so marked a characteristic of the Justin Morgan, never failing to attract and fasten the attention of the most disinterested observer. In these great qualities little room was left for improvement, and perhaps the most that can be expected is to maintain their reputation in these respects. In these traits of spirit and temper, as well as in their size and general form, we believe they approach much nearer the Arabian or the English thorough-bred of a century since, than does the racehorse of the present day. This we think will appear evident from a comparison of the best specimens of the Morgans with the likenesses of the most celebrated 
thorough-breds of the last century, and with the descriptions given by all travellers of the Arabian, as he exists in his native deserts, and also with the portraits of the most fishionable thorough-breds of the present day in this country.

To show his resemblance to the English thoroughbred of a hundred years ago, we have placed at the head of this chapter a portrait of the celebrated horse Gincrack, copied from an engraving of him published in the sccond volume of the "American Turf Register and Sporting Magazine." We have selected this horse, not because the Morgan horse more nearly resembles him than others of his time, but because he was one of the most noted horses of that day in England, and both he and his descendants have been justly celebrated for their speed and endurance.

Accompanying the portrait of Gimcrack, in tho "American Turf Register," is a short Memoir of him, from which we extract the following:

"Gimcrack, the sire of Medley, was one of the most remarkable horses of his day in England. He was a gray, and called the 'little gray horse Gimorack,' foaled in 1760; got by Cripple, a son of the Godolphin Arabian; dam, Miss Elliott, by Griswood's Partner; grand dam, Celia, by Partner; Bloody Buttocks, Greyhound, Blockesby, Betty. Gimcrack was one of the severest running and hardest bottomed horses that ever ran in England; although small, yet his ability to carry weight was very great, for he frequently gave the odds as high as twenty-eight pounds, and he continued on the turf until eleven years of age, thereby showing his uncommon hardiness of constitution and 
firmness of limbs. *** * * Gimcrack had acquired such fame and celebrity that his last proprietor left him a length of time at Tattersall's for the inspection of the public."

A careful comparison of this portrait with the cuts in this volume, and with those of the fashionable thorough-breds of the present day, will show that the Morgans bear the closest resemblance to the Arabian. or thorough-bred of a hundred years since.

Little or no change seems to have taken place in color in the progress of the race, bays and chestnuts being the prevailing color of the Morgans, as it is of the racehorse. It will be remembered that of the three stallions -the Woodbury, Bulrush, and Sherman-two were chestnut and the other bay, and these are now the only colors often met with. In speaking of the breed as they now exist, it will be understood by the intelligent. reader that no notice will be taken of animals having only a slight tinge of Morgan blood, but only of those bred from Morgan stallions of repute where they are known. The only important exception we have known to this general rule of color is in the case of Black Hawk, who is jet black, and takes his color from the dam.

Very many of his colts take their color from him, but some of them do not; and when not black they are almost invariably bays or chestnuts. It is a curious fact that most of his colts, which take their general color from him, have the white stripe in the face, and the white hind feet that belonged to their grand sire, the Sherman.

It is probable that the short fare and hard service to 
which the original Morgans were put, somewhat checked their growth, so that they had less size than they would have had under better fare and less scvere labor. It is certain that the true Morgans of the present day are decidedly larger than the original stock. First let us compare some of the most noted of the grandsons of the Justin Morgan with him, and we shall see that they are, or were, larger. Black Hawk, height 14 hands, weight 1000 pounds; Royal Morgan or Crane horse, height $13 \frac{3}{4}$ hands, weight 1020 pounds: Gifford, height $14 \frac{1}{2}$ hands, weight 1000 pounds; Barker horse, height 15 hands, weight 1075 pounds; Morgan Emperor, height 15 hands, weight 1025 pounds; Morgan Trotter, height 141 hands, weight 1050 pounds.

These are taken equally from the Bulrush, Sherman, and Woodbury branches, and were all of them noted stallions. By an examination of any considerable number of stallioins of this breed as now kept, any good judge will be satisfied that the race has decidedly increased in size. To show that the above opinion, formed at first by the eye after examining a great number of these horses, is correct, we have resorted to the United States Agricultural Society's published report of their exhibition at Boston, in October, 1855. The number of stallions exhibited was one hundred and thirty; and of these, seventy were of Morgan blood. The weight of twenty-five of these is given, but three of them are four years old and under. Excepting these, because not fully grown, the average weight of the remaining twenty-two is 1040 pounds. This we think may be considered a very fair 
statement of the average .weight of these horses, as among them were horses of every size that can be found of this breed in our State. It is certain that the size has been increased.

As to their compactness, strength of constitution, and power of endurance, we can see no reason for believing that there has been any deterioration. That they have retained their compactness, is so evident and so well known, as to admit of no question; and the eagerness with which they are purchased by the stage, omnibus, hack, and livery stable owners throughout the country, seems to us the highest evidence that the Morgan's constitution is yet sound, and his powers of endurance still equal to the most laborious service. There is no breed of horses among which there cannot be found unsound individuals; and too severe work and brutal treatment will sometimes bring founder, ringoone or sparin, broken wind, debility and disease, upon the finest limbs and the hardiest constitution; but we believe no breed of horses can be pointed to in this country more generally free from every description of unsoundness than the Morgan.

Iittle or no change seems to have taken place in the head and neck. The same light, lean head, small, pointed, and sensitive ears; the same brilliant, prominent, restless eye, seems as strongly developed now as in the first of the race; while the neck, rather short, is carried in the same proud and lofty manner that attracted the attention of all who ever saw the Justin Morgan. The general structure of the body is unchanged. In his short, bony legs, compact body, deep, 
roomy chest, oblique shoulders, short back, and mus. cular quarters, he still exhibits the marked features of his illustrious ancestors.

The present Morgans have not so much of the long hair of the Justin Morgan on their legs. This is an improvement, as the long hair on the legs is unsightly, inconvenient, and in no sense useful.

His gait or natural pace seems to have undergone little change. It may be that his stride is a trifle longer, and it is our belief that it is; but of this it is difficult to judge correctly, and it is certainly very doubtful.

The greatest change in the going of the Morgans consists in this, that the present animals of the breed are faster trotters than their ancestors. In the time of the Justin Morgan, trotting was not much practiced. Fast trotting dates from the introduction of the light buggy. Since that time the horses in Vermont have been trained to that gait to the exclusion of almost all other paces. The art of training the horse to this pace, and developing his utmost powers in it, was not then understood. But we do not think the most consummate sliill in training of the Justin Morgan would have enabled him to compete successfully with many of his descendants. This increased speed in the trot we think is mainly attributable to their constant training to this pace through several generations.

That the training and using animals for a particular service begets in them a capacity for that service, and enables them to excel therein, is a truth that we think is generally asserted by the best writers, and admitted by the most intelligent breeders. A remarka- 
ble illustration of it may be seen in the pointer, which was originally bred from the hound; yet how widely different have their very instincts become by being long used and trained to entirely different kinds of hunting. Take the young hound for the first time alone into the field, and watch his unchecked, and un: guided movements; he ranges about, trotting heedlessly over the partridge, the woodcock, or the prairie chicken; even the whirr of the rising quail fails to attract his attention; but let him come upon the fresh track of a fox, and instantly his deep startling bay makes every echo ring, and wild with excitement he dashes off in eager pursuit of an animal he has never seen.

Not so the high bred young pointer. He crosses the path of the fox indifferent to the steaming scent, but let a breath of air bring to him the odor of the unseen partridge, and he is instantly as motionless as if cut from marble; true, he has not yet learned the full extent of his duty, but how strikingly does this action exhibit the effect of training and using for a particular service for many generations. If this were not a general law, how should we ever succeed in domesticating animals? the colt foaled to-day would be as wild and untractable as his untamed ancestors a thousand years ago.

It can hardly be questioned that a general improvement has been steadily going on in the character of our horses. This we believe to be in a great measure due to the peculiar fitness of our soil and climate for this branch of agriculture, but our breeders have of late years been incited to endeavor to produce the best animals by the profit they offered. In addition to the 
stimulus given to breeders to produce the best stock by the constantly increasing demand for it, there has arisen within the last few years a new influence, to aid in improving the character of our horses. We allude to the agricultural societies that have been formed in almost every county throughout the country. At the exhibitions of these societies, the finest animals are brought together, and farmers and breeders are thus enabled to compare the different animals, not only with one another, but also with that ideal standard of excel. lence that each breeder has, or ought to have set up, of the kind of animal he is endeavoring to produce.

At these fairs the young and inexperienced breeder meets many who have devoted years of close attention to the business in which he is just engaging; and by conferring with them, he may be able to shun their errors and take advantage of their success.

From able speakers he hears many important truths that will prove of inestimable advantage to him, provided he cherishes them as he ought. The old adage that "competition is the life of trade," is as applicable to farming as to any other kind of business; and the healthy competition that these fairs or exhibitions excite among breeders is of great advantage to them, by stimulating them to make exertions to produce the best animals, and instructing them in the great principles by which they must be guided, if they would deserve success.

The beneficial influence of these exhibitions can hardly be over-estimated; and, as they have hitherto been, so will they continue to be, powerful engines of good, so long as they are wisely and skilfully conducted. 
These are some of the principal influences that are constantly stimulating Vermont breeders to keep up and improve the well-earned reputation of her horses. The materials are now abundant; and if by association or otherwise they can be retained in the State, and properly bred, there can be little question that Vermont can for years to come furnish her sister States and the great markets, with the best business horse raised in any country in the world. 


\section{CHAPTER X.}

PERFORMANCES OF MORGAN HORSES - THE DEMAND FOR THEM AND THEIR PRESENT VALUE AS INDICATED BY SALES.

THE question has been sometimes asked, "What have Morgan horses ever done to entitle them to distinction?" Coming as it almost invariably does from persons interested in some other breed, the question implies a disbelief in the ability of Morgan horses to perform any feats of speed or endurance worthy of notice; and, as such individuals doubtless deem it for their interest to continue in their present faith, we shall make no effort to convince them of their error, being: satisfied that we should have little chance of success, opposing as we should both their interests and their prejudices.

But there are others who make the inquiry from a simple desire for information, in relation to a breed of horses with which they are unacquainted, and we trust that to such the facts we shall state in this chapter will prove a satisfactory answer.

Let us first consider what are the qualities for which it is claimed they are distinguished, as it is manifest the performance should be of such a nature as will call into exercise these qualities.

The Morgan claims to be chicfly valuable as a driving-horse with moderate weight, or in other words, as a business horse. In a previous chapter, we have stated 
the principal qualities which the business horse should possess. The degree in which a horse possesses these qualities cannot always be tested; as, for instance, we may test his speed or his endurance, but we judge of his form, his style of movement, his spirit, or his temper. Speed and endurance are indispensable; a suitable form, a lively spirit, and a tractable temper, are qualities scarcely less important. Possessed of the former, he has the power to perform great feats upon tho road; possessed also of the latter, that power becomes available, and can be applied to some useful purpose. The speed and endurance of the horse can, of course, be tested by driving him on the road, or the race-course; the former can be determined by driving a short distance; the latter, by driving a long time. We know it is very commonly said, that a horse has a great deal of bottom or endurance which can keep up a high rate of speed for from five to ten minutes; but this is not the kind of endurance we are speaking of. The endurance wanted in the driving-horse must be such as will enable him to last throughout the day, and from day to day, or from week to week. Many horses drive well and with much spirit for a short time, but are unable to endure a single day's drive; and many that can perform a very creditable day's journey are unable to last through a week of hard work. It is to such horses that the old stable-saying refers, "some horses will go so far in a day that they can't get back in a week." Youatt elearly asserts this fact: he says, "Many horses with narrow ehests, and a great deal of daylight under them, have plenty of spirit and willing. ness for work. They show themselves well off, and 
exhibit the address and gratify the vanity of their riders on the parade or in the park, but they have not the appetite nor the endurance that will carry them through three successive hard days' work."

The Morgan horse may not exhibit the greatest speed for a short distance; indeed, we do not think his form is such as is best suited to such extraordinary speed; but he has such an amount of speed as "entitles him to the appellation of a fast traveller." We do not think that great speed and great endurance are usually found combined in the same animal; to support this opinion, we again refer to Youatt, who says: "Some of our saddle horses and cobs have barrels round enough, and we value them on account of it, for they are always in condition, and they rarely tire. But when we look at them more carefully, there is just that departure from the circular form-of which mention has just been made-that happy medium between the circle and the ellipse, which retains the capacity of the one and the expansibility of the other. Such a horse is invaluable for common purposes, but he is seldom a horse of speed. If he is permitted to go his own pace, and that not a slow one, he will work on forever; but if too much hurried he is soon distressed." And again he says: "The question then is, what service is required from the horse? If he has to carry a heavy weight, and has much work to clo, he should be ribbed. home-the last rib and the lip-bone should not be far from each other. There is more capacity of ehest and of belly-there is less distance between the points of support-and greater strength and endurance. A 
hackney (and we would almost say a hunter) can scarcely be too well ribbed home.

"If speed, however, is required, there must be room for the full action of the hinder limbs; and this can only exist where there is sufficient space between the last rib and the hip-bone. The owner of the horse must make up his mind as to what he wants from him, and be satisfied if he obtains that; for let him be assured, that he cannot have everything, for this would require those differences of conformation that cannot possibly exist in the same animal."

To the practical horseman, the simple fact that an animal has trotted a mile in $2 \mathrm{~m}$. $30 \mathrm{~s}$, or two miles in $5 \mathrm{~m} .10 \mathrm{~s}$., will afford little evidence of its power of endurance in the livery stable, before a hack, or a Broadway omnibus. Occasionally a long race is trotted that serves to test the endurance of the horse, but these are of so rare occurrence that almost the only recorded testimony of the lastingness of the Morgan horse is found in general statements of the fact, rather than in recorded instances of its exhibition by individuals of the breed. The quotations we have already made in a previous chapter, from writers of unquestioned authority, will, we think, fully establish their claim to more than ordinary powers of endurance.

We have said that we do not think the form of the Morgan horse is such as is best adapted for the greatest speed at short distances; still, among any breed of horses sufficiently fast to be called rapid travellers, individuals will occasionally be found that will be fast for short distances, and such is the case with the Morgans. 
That such is the fact, we think the well-authenticated performances we shall mention will abundantly establish.

Before speaking of these performances, a few remarks seem necessary, in order that the relative importance of these performances may be understood.

Quite a diversity of opinion exists among sporting men as to what rate of speed for a mile entitles a horse to be ranked as a sporting horse; this must necessarily be the case, since no abstract rule can be laid down. It seems to us that a horse must be admitted to be a fast, or sporting horse, that can make his mile in less time than a majority of those he will be obliged to contend with on the race-course. To enable us to form some idea of the ordinary or average speed of the trotting horses of the country, we have made a summary of all the time, at mile heats, reported in the "New York Spirit of the Times," for the year 1852; and the average time made by winning horses at mile heats during that ycar was $2 \mathrm{~m}$. 50s. and a small fraction. Our only reason for selecting that year was, that the volume of the "Spirit of the Times" published that year was the only complete one which we had at hand. From this it is plain that a horse which could trot a mile within $2 \mathrm{~m}$. $50 \mathrm{~s}$. would have been able to defeat a large majority of the trotting horses of the country.

We are aware that many persons affect to believe that a trotter is no sporting horse if he cannot "go low down in the thirties," but it is plain this is a mistake. The horse which can trot a mile in $2 \mathrm{~m}$. $40 \mathrm{~s}$. in good style, we feel confident will prove too fast for three. quarters of the trotting horses of the country. 
One of the most remarkable trotting horses ever known, and without any question the fastest horse of her time at long distances, was "Fanny Jenks," the property of Gen. A. T. Dunham, of Troy, N. Y. We are unable to give her pedigree, but she was raised in Vermont, and was always called a Morgan; and her form and style of movement exhibited in a high degree the characteristies of the breed. She was fourteen and three-quarters hands high, and in medium condition weighed nine hundred and thirty-five pounds. From Vermont, she was taken to Watertown, Jefferson county, N. Y., and became the property of Gen. Pratt. In the year 1839 or 1840 , the General took her to Troy and sold her to Willard Jenks, of West Troy, and of him she was purchased by Gen. A. T. Dunham. Her first important performance was at Centreville, L. I., in October, 1844, when she trotted ten miles before a sulky, earrying $145 \mathrm{lbs}$., in $29 \mathrm{~m}$. and $59 \mathrm{~s}$., beating Neptune and Misfortune. On the 5th of May, 1845 , in a match against time for $\$ 500$, to trot one hundred miles in ten hours, over the Bull's Head Course, near Albany, N. Y., she performed the entire distance in 9 hours 42 minutes and 57 seconds. Exclusive of the time in stopping for refreshment $(18 \mathrm{~m}$. $27 \mathrm{~s}$.$) , she performed the distance in 9 \mathrm{~h} .24 \mathrm{~m} .30 \mathrm{~s}$.

Of this performance an article in the "Spirit of the Times," headed "Fanny Jenks against the World," says: "Immediately on the completion of the match, and without stopping, she was trotted once round the course, and accomplished her 101st mile in $4 \mathrm{~m}$. 23s.

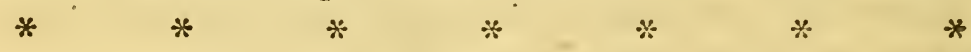

"The mare showed no symptoms of distress at any 


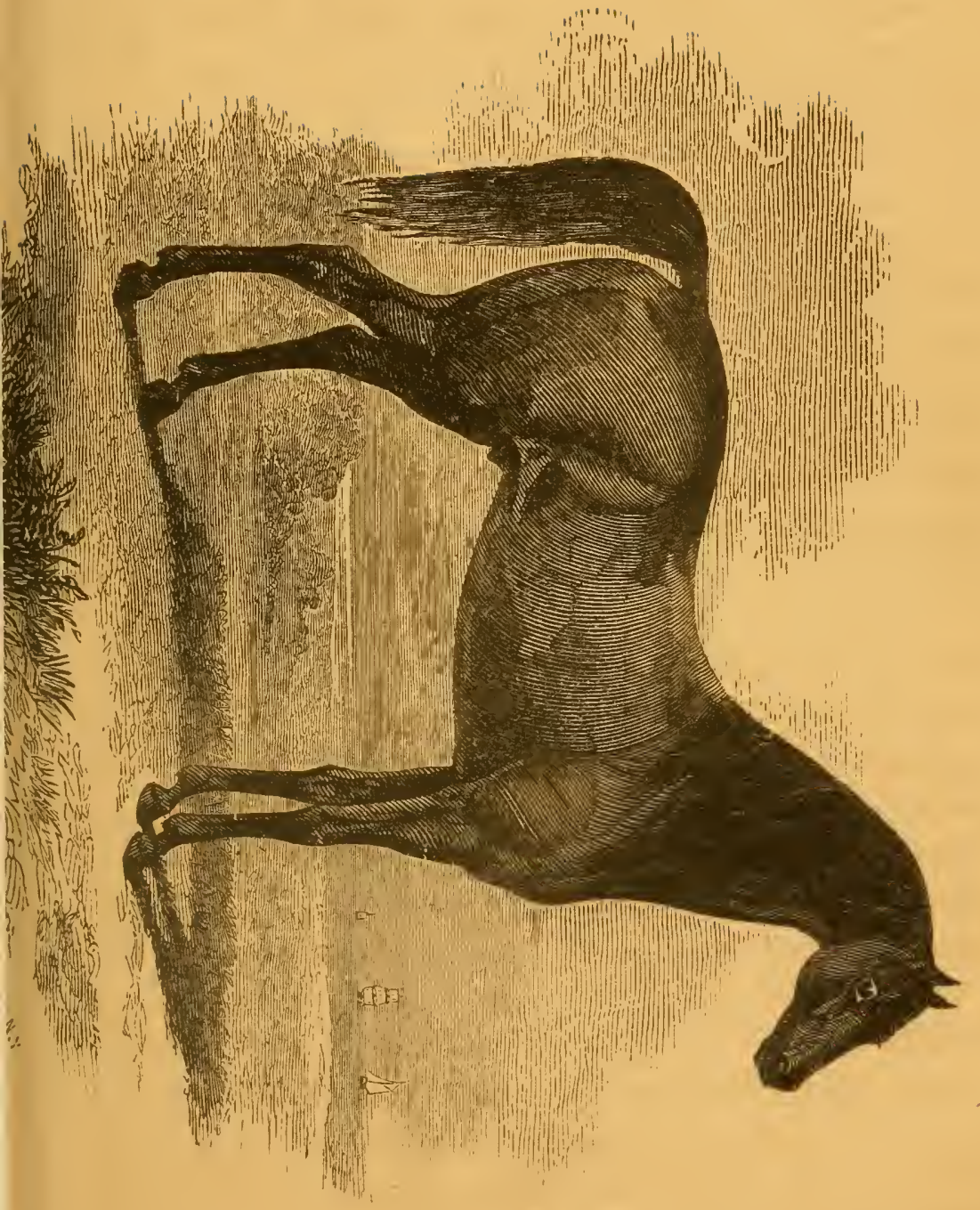



period of the performance, and her indomitable game was fully evinced by her speed in part of her last time, and the ravenous manner in which she attacked her hay as soon as led to the stable.

"On the following day she was driven twelve miles (to Albany and Troy), exhibiting no soreness, stiffness, nor any other evidence that she had performed her wonderful feat so recently."

In 1842 , Black Hawk won a match of $\$ 1,000$ by trotting five miles over the Cambridge Park Course in sixteen minutes. In 1843 , October $3 \mathrm{~d}$, he won a race of two mile heats, best two in three, beating Jim and Dying Sergeant with ease in $5 \mathrm{~m} .43 \mathrm{~s} .-5 \mathrm{~m} .48 \mathrm{~s} .-5 \mathrm{~m}$. $47 \mathrm{~s}$. Single miles he made at different times in $2 \mathrm{~m}$. 42 seconds.

At Boston, Nov. 3d, 1853, Black Hawk Maid beat Blue Morgan, two mile heats, best two in three. Time, 5m. 23s.-5m. 22s. -Black Hawk Maid was sired by Black Hawk.

The 20th of September, 1847, over the Union Course, L. I., Lady Sutton beat Sal and Grey Eagle, two mile heats, best two in three, in harness. Time, $5 \mathrm{~m} .17 \mathrm{~s}$.$5 \mathrm{~m} .21 \mathrm{~s}$, and again Sept. $27 \mathrm{th}$, of same year, she beat the same horses same distance. Time, $5 \mathrm{~m} .22 \mathrm{~s} .-5 \mathrm{~m}$. 28 seconds.

The 19th of May, 1848, a trot came off over the Union Course, L. I., that created a good deal of excitement, and is well remembered by sportsmen on account of the celebrity of the horses, and the severity of the contest. The race was between Lady Sutton, Lady Suffolk, and Lady Moscow, mile heats in harness, and was won by Lady Sutton after a long and close struggle. 
Time, 2m. 33s.-2m. 33s. $-2 \mathrm{~m}$. 35̌s. $-2 \mathrm{~m}$. 37s. $-2 \mathrm{~m}$. $38 \mathrm{~s} .-2 \mathrm{~m} .36 \mathrm{~s}$.

Lady Sutton was raised in Barre, Vermont. She was sired by Morgan Eagle, a grandson of the Justin Morgan. The dam of Lady Sutton was called a Morgan mare, but we do not know her pedigree. Lady $\mathrm{S}$. is not over fourteen hands high, has a fine figure, and a nervous, spirited style of action, with plenty of speed and endurance. She is too nervous and hightempered to make a sure and safe trotting horse, and endure quietly and patiently all the accidents and mishaps of the race-course.

On the 26th of June, 1843, a fast and well-contested race came off over the Beacon Course, New Jersey, between Beppo and Independence, mile heats, best three in five, and was won by Beppo. Time, $2 \mathrm{~m}$. $32 \frac{1}{2} \mathrm{~s}$.$2 \mathrm{~m} .31 \frac{1}{2} \mathrm{~s} .-2 \mathrm{~m} .33 \mathrm{~s} .-2 \mathrm{~m} .38 \mathrm{~s} .-2 \mathrm{~m} .35 \mathrm{~s} . \quad$ Beppo was sired by Gifford.

On the 29th of September, 1843, a race came off over the Cambridge Park Course between Pizarro, Forest Maid, and Lady Swan, mile heats, best three in five, and was won by Pizarro in three straight heats. Time, $2 \mathrm{~m}$. $35 \mathrm{~s} .-2 \mathrm{~m}$. 39 $\frac{1}{2} \mathrm{~s} .-2 \mathrm{~m}$. $37 \frac{1}{2} \mathrm{~s}$. Pizarro was sired by Morgan Casar.

On the $2 \mathrm{~d}$ of May, 1853, a race took place on the Hunting Park Course, Philadelphia, between Vermont Boy and Soto, three mile heats, to wagons, best two in three, won by Vermont Boy. Time $8 \mathrm{~m} .32 \mathrm{~s} .-8 \mathrm{~m} .47 \mathrm{~s}$.

On the 10th of May, 1853, a match took place on Long Island between Ethan Allen, three years and ten months old, and Rose of Washington, several months older for one thousand dollars a side, mile 
heats, best three in five. This match attracted much attention. Many who knew the mare thought she was sure to win, as she was deemed the fastest horse of her nge in the country; but the event proved they were mistaken, as the horse beat her in three straight heats. Time, $2 \mathrm{~m} .42 \mathrm{~s} .-2 \mathrm{~m}$. 39s. $-2 \mathrm{~m} .36 \mathrm{~s}$.

We believe this is the fastest time on record by a horse of his age. We think his only other public trot was at Boston, Oct. 27th, 1855, at the Fair of the United States Agricultural Society, where he received the first premium for speed, beating Columbus, Sherman Black Hawk, and Stockbridge Chief. Time, $2 \mathrm{~m}$. $34 \frac{1}{2} \mathrm{~s} .-2 \mathrm{~m}$. 37s. Ethan Allen was sired by Black Hawk, and is doubtless the fastest trotting stallion that has ever appeared on the turf.

November 24th, 1853, Blue Morgan won a race over the Cambridge Park Course, beating Black Hawk Maid, mile heats in harness, best two in three. Time $2 \mathrm{~m} .38 \frac{1}{2} \mathrm{~s} .-2 \mathrm{~m} .33 \frac{1}{2} \mathrm{~s}$.

August 20th, 1852, Black Ralph won a race at Saratoga, beating Murdoch, mile heats under the saddle, best three in five, wiuning the 1 st, $3 \mathrm{~d}$ and 5 th heats. Time $2 \mathrm{~m} .32 \mathrm{~s} .-2 \mathrm{~m} .30 \mathrm{~s} .-2 \mathrm{~m} .31 \mathrm{~s} .-2 \mathrm{~m} .38 \mathrm{~s} .-2 \mathrm{~m}$. $34 \mathrm{~s}$.

October 6th, 1852 , in a race between Murdoch and Black Ralph, two mile heats under the saddle, Ralph won the first heat in $5 \mathrm{~m}$. $13 \frac{1}{2} \mathrm{~s}$, though beaten by Murdoch in the race. Black Ralph was sired by Black Hawk.

October 14th, 1854, Know-Nothing won a race over the Cambridge Park Course, beating Black Hawk Maid, two mile heats in harness. Time 5m. 26s. Mare drawn after the first heat. 
In a match between Know-Nothing and Chicago Jack over the Cambridge Park Course, May 11th, 1855 , mile heats under the saddle, best three in five, Know-Nothing won the first heat $2 \mathrm{~m} .27 \frac{1}{2} \mathrm{~s}$, but was beaten in the race by Chicago Jack, who made the third heat in $2 \mathrm{~m} .27 \frac{1}{2} \mathrm{~s}$. Know-Nothing was sired by Black Hawk, and was only five years old; his dam is said to have been sired by a grandson of Lee Boo. Chicago Jack was raised in Illinois, and we think was sired by Morgan Emperor, formerly owned by L. Butler, of Chicago, Illinois.

The 29th of July, 1856, a race took place over the Fashion Course, Long Island, being a match between Know-Nothing and Flora Temple, mile heats, best three in five, Know-Nothing under the saddle - Flora Temple in harness. Though matched against the fastest trotting horse in harness ever known, the friends of Know-Nothing felt such confidence in his powers that they backed him freely, offering odds that were quickly taken. The race was won by Know-Nothing, in three straight heats. Time $2 \mathrm{~m} .29 \mathrm{~s} .-2 \mathrm{~m} .29 \mathrm{~s}$ $2 \mathrm{~m}$. 30s.

September 25th, 1855, Belle of Saratoga won a match of $\$ 500$, mile heats, best three in five, over the Centreville Course, beating Murdoch in three straight heats.

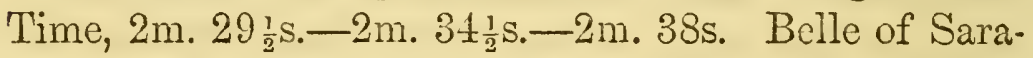
toga was sired by Black Hawk.

A race on the ice near Plattsburg, February 27th, 1852, mile heats in harness, best three in five, was won by Sherman Black Hawk, in three straight heats, beating Flying Morgan and a gray gelding from Can. ton, N. Y. Time 2m. 47s. $-2 \mathrm{~m} .44 \mathrm{~s} .-2 \mathrm{~m} .42 \mathrm{~s}$. 
In March, 1850, a race on the ice, mile heats, best two in three, was won by Flying Morgan, in two straight heats, beating Tramp. Time $2 \mathrm{~m} .51 \mathrm{~s} .-2 \mathrm{~m}$. 48s. Flying Morgan was sired by the Hackett Horse. In a race over Cambridge Park Course, October 2d, 1851, mile heats, best three in five, between Flying Morgan and Cleopatra, the former was victorious in three straight heats. Time $2 \mathrm{~m} .51 \mathrm{~s} .-2 \mathrm{~m} .51 \frac{1}{2} \mathrm{~s}$. $-2 \mathrm{~m}$. 57s. In this race Flying Morgan was called Burlington.

There are many others well known as Morgan trotters of celebrity, which we have not space to notice, such as Henry Clay, sired by Gifford; Grey Hawk, of Chicago, sired by Morgan Tally Oln; Whalebone, sired by Whalebone or the Clarke Horse; Lady Sherman, sired by Black Hawk, \&c., \&c.; there are also others about whose pedigree there is some dispute, but which are claimed as of Morgan descent, such as Mac, Lady Fulton, \&c.. Mac was raised in Maine, and his dam was probably a descendant of Messenger, but there is little doubt that he was sired by Morgan Cæsar, one of the best grandsons of the Justin Morgan.

We think the above performances fully establish the truth of our proposition, that although it is not claimed their form and gait is such as is best adapted to make the quickest time for a mile, yet the Morgans being as a class fast travellers, some individuals exhibit great speed.

There is no doubt that if our farmers and breeders would take pains to develop the utmost power of their horses in the trot, very many would exhibit a good deal of speed. But no such effort is generally made; our 
people are not a sporting people. There is not a race course, properly speaking, in the State. True, some of the Agricultural Societies have graded temporary half. mile tracks, not only to give opportunity to test the speed of horses, but to exhibit their paces, training, and style of movement. They are not simply racecourses, and we hope that while the property of these societies they may never become such.

We have no objections to trotting matches, and are willing that those who choose should engage in them. They certainly tend to develop one of the valuable qualities of the horse, and we cannot object if the patrons of the turf offer premiums for excellence in that one quality which is almost the only one by them esteemed. But it seems to us eminently improper for Agricultural Societies to offer such premiums for a single good trait in an animal, without considering the many others equally important. A good form, temper, action, and style of movement, suitable size, speed, and endurance, are each valuable qualities in the business horse; but superlative excellence in any one of them alone, ought not to entitle a horse to rank above rivals superior to him in all other respects. Should any Agricultural Society deem it advisable for farmers to aim to produce horses whose excellence should consist solely in their speed, they might consistently offer such premiums.

It is a trite saying that an article "is worth what it will bring in market."

Estimating the value of Morgan horses by this standard, we shall find that they are unequalled by any horses in this country. We have already en. 
deavored to show that they possessed great merit, but great merit is not always properly appreciated; hence the inquiry, "will they command such prices as will remunerate the breeder?"

That they do command not only remunerating, but very high prices, can be abundantly shown; indeed, those least friendly to the Morgans admit that they are in great demand, and that they sell for high prices. Instances might be given in which individuals of the breed have been disposed of at very great prices, and indeed they might be multiplied to almost any extent, but should not and would not establish the general rule, for there is no breed of horses of any note, individuals of which are not sometimes sold for high prices.

In Mr. Burnet's "remarks on breeding horses," to which we have before referred, although he does not admire the Morgans, yet he admits that "they sell readily at high pricès."

The editor of the "Country Gentleman," in an article giving an account of the National Exhibition of horses at Springfield, in 1853, says, in reference to the Morgan horses of Vermont, "It was seen by the originator of the movement, and by those who sympathized with him, that New England and the country generally were indebted to a single State for the most of their desirable and valuable horses.

"It was seen that single breeding animals had been the source of almost millions of revenue to the breeders of their respective localities, and that in a majority of the States of the Union it was almost impossible to find a horse bred at home that was of high value."

The "Maine Farmer," in an article before quoted, 
says, "For a seller of horses, it is only necessary for him to establish the fact that his horses are of the Morgan blood, and be meets with a ready sale at good prices, and the purchasers are more than satisfied."

Mr. H. S. Randall, in his account of the breeds of horses in the United States, says, "That they have sold for high prices, not only for the saddle and buggy, but as stallions to extend the breed, is certain. They have many warm admirers, and find ready purchasers."

Almost any number of similar extracts might be added, but the foregoing seem sufficient, especially as we have never seen it denied that they sell readily at prices amply remunerating. It is evident that this must be the case, when we consider that they are not bred in any numbers save in a small district of country, and that the demand for them comes from every State in the Union; many being yearly taken to all parts of New England, and to the West and South.

The prices at which they have been sold have been constantly increasing since the death of the Justin Morgan. One of the colts of the Justin Morgan (Woodbury) was sold when about ten years old to Mr. William Walker, of Hartland, Vt., for five hundred dollars, which was at that time considered a most extravagant price; but if the same horse was now living, he would command more than ten times that sum. Ordinary stallions could be purchased at that time for from one to two hundred dollars.

The more widely and thoroughly they are known, the greater has been the demand for them. Fifteen years ago the best stallions could be procured for from five to fifteen hundred dollars, the best geldings for 
from one hundred to one hundred and fifty dollars, and the best mares at from one to two hundred. Now the best stallions cannot be procured for less than from one to three thousand dollars; the best geldings sell readily at from two to four hundred dollars, and the best mares at from three to six hundred. Horses possessing extra value on account of their speed, are not included in the foregoing statement, as for such very much larger prices are often paid. We know that some will say our prices are too low, and point us to very many sales at much higher prices, of animals having no reputation for great speed, but we think that although there may be many such instances, they are the exceptions to the general rule, rather than the rule itself. Again we may be told that our minimum prices are too high, and instances adduced of animals of good blood and form that have been purchased for less. We know that under favorable circumstances such animals may occasionally be purchased by persons well acquainted throughout the State, and constantly on the watch for favorable opportunities, at prices somewhat less than those we have named. Yet, as a general thing, when the price is much below what we have stated, we should be suspicious that the blood or form was not of the first quality. 


\section{CHAPTER XI.}

EINTS AS TO THE BEST METHODS FOR IMPROVING AND PERPETCATING THE BREED.

T'HE proposition that "like will beget like" is generally received as an axiom by intelligent breeders of domestic animals. Although as a general proposition this is doubtless true, yet we should make a great mistake to expect that a male and female unlike each other would produce offspring like either. Before the proposition will hold true, the sire and the dam must be like each other. Even this is not sufficient; the progenitors of each must have been alike for some generations.

The most careless breeder can hardly fail to observe qualities appearing in his stock, that belonged neither to their sire nor dam, but which belonged to some of their ancestors farther back; such, for instance, as a vicious temper, some striking peculiarity of form or color, or some peculiar mark, such as a white face, white feet, \&c. The chances that the good, and the danger that the bad qualities of an ancestor, will be inherited by any animal, will depend upon the number of degrees he is removed from that ancestor, unless his ancestors of the opposite sex have exhibited the same qualities, and have exhibited them in each generation. (200) 
When the ancestors upon both sides for some generations have been alike in all their important features, then "like will beget like." Not that the animals bred will be alike even then; they will only be alike in the prominent characteristics of the race. There will still be every degree of excellence. Some will be less perfict in form than others, and some with forms neaily faultless, will yet lack some essential requisite to give them the highest value. This is strikingly exemplified in the breeding of the race-horse. Immense fortunes have been expended, and time and talents freely given for the improvement of those qualities that render him valuable for the service to which he is put, yet comparatively very few of them prove exccllent in the very points to which the attention of the breeder was particularly directed. Now, if we were to breed from the poorest instead of the best specimens of the race-horse, it is evident that he would very rapidly deteriorate in all those qualities that now render him valuable, and the extraordinary speed he has attained would soon be lost. The manner in which they have attained their unrivalled speed is by breeding those stallions exhibiting in the highest perfection the qualities sought, to mares possessing in a high degree the same characteristics.

This points out not only the best method for perpetuating the qualities of a breed of animals whose characteristics have become fixed, but it also points out the proper method of improving them. The Morgan horse has not yet fully attained to this point; that is, his characteristics have no: yet been fully and firmly established. If the breed is perpetuated, it is evi- 
dent it can never be by the use of Morgan stallions Blone.

Mares of Morgan get must be selected, and the more crosses of Morgan blood in the dam the better; and those should be chosen which are fully up to the average size of the race, and exhibit in a high degree the peculiar characteristics of the breed to which they belong. It will, however, be no objection to the mare if she be not quite as well "ribbed up" as the sire, and she may be a little longer bodied; many breeders would prefer that she should differ from the sire in these respects; but it should not be forgotten that extreme length of body, combined (as it usually is) with flat sides and narrow loins, is a far from desirable figure.

Youatt says, "It may perhaps be justly affirmed that there is more difficulty in selecting a good mare to breed from than a good horse, because she should possess somewhat opposite qualities. Her carcase should belong, in order to give room for the growth of the foetus; and yet with this there. should be com. pactness of form and shortness of leg." The Mol. gan mare should have a clean, light head, spirited, but mild, pleasant eyes, set wide apart; but above all other qualities she should possess a sound, hearty and iron constitution, with abundance of nervous energy. The stallion should be selected partly with reference to the form and characteristics of the mare, and he should. possess in a high degree those good qualities in which the mare is most deficient. In all cases he should be compact and possessed of a vigorous constitution, have a bold, resolute style of action, high spirit, and a great 


deal of that nerrous or vital encrgy, which gives life, vigor, and endurance to the whole.

There are two errors very commonly committed by persons selecting animals from which to breed. Some pay too much attention to pedigree and too little to form; while others err in the opposite direction. The one will select the animal with the longest pedigree, whatever be his form, while the other says, "I don't care about your pedigree, but show me your horse." The latter is of the two, the least objectionable, for the stock will be far more likely to inherit the qualities of an immediate, than those of a remote ancestor. Hence it is that persons having fine animals, possessed of extremely short pedigrees, are fond of displaying in glaring capitals that trite old saying, "Llood is blood, but form is superiorily."

The meaning of this, although a little obscure, wo think is, that blood is a very excellent thing; but that when the form and general characteristics are of the highest order, they are more important than any pedigree. Many persons, however, seem to understand this very differently, and think it asserts that though blood is a very good thing, yet when an animal can be found of almost faultless form and possessing qualitics of the highest order, it is of no consequence what is his blood.

The truth is, that though form and character are of primary importance, the blood should never be neglected. This is true when the breeder intends his stock for the great markets of the country; but when he intends to breed a stock for his farm for the purpose of again breeding from them, the blood 
of the animal becomes vastly more important; and he who breeds from animals whose immediate ances. tors were of unknown descent, will be pretty sure to repent of his error.

Another common error is, to search eagerly for animals to breed from, that have become noted for their speed. IIany persons can he found who will pick up some long-legged, rangy, broken-down trotting mare, which perhaps could trot a mile in 2.30 , and think by breeding her to a Morgan stallion, something very fine may be expected. Nothing can be more ill-judged than such a course; and in a large majority of cases it is sure to end in clisappointment and loss. Occasionally, (and it must be remembered it is only occasionally,) the? progeny of such an animal may exhibit great speed; but the great proportion of them will be found to have inherited her form but not her speed, and hence are of small value.

The only course to pursue to keep up the Morgan breed, is for breeders to retain their best mares for the purpose of breeding. This matter cannot be too strongly impressed upon farmers, and all who are interested in tho subject. There is another danger that breeders must guard well against. The high prices that Southern and Western buyers are offering for the best stallions, is draining the home region rapidly. If the best are sold, and only the indifferent retained, it is easy to sce that some other part of the country, with enterprise enough to buy your best animals, will raise better Morgan horses than you can, as they will have better stock. No country can long retain a superior race of animals, who sell all the best of the growth and 
increase. This is so obvious that no argument or discussion is required to show its truth. Some breeders are already aware of this danger, and will no doubt use their influence to prerent it. We know of some choice animals that have been held, notwithstanding the most tempting offers from abroad.

As the most spirited breeders are now making great profit by breeding from first-rate animals, their example will produce more effect than anything which can be written on the subject. We know of some Morgan mares which have been put to breeding that are valued at a thousand dollars.

The English have paid more attention to breeding, and with more success, than almost any other people Their abundant capital, paid freely for choice animals to breed from, shows us the means which they have used. As many of the landholders in England are persons of great wealth, they have not been deterred by high prices from obtaining the finest animals. Their example is worthy our most careful consideration; for they have had great experience, and the best talent of the country has been called to their aid. There are some breeders of Morgan horses who, although they will not breed from animals decidedly inferior in form, merely because they may happen to be fast, are yet inclined to lay too much stress upon great speed-a good quality, but one which we think is often purchased at the expense of qualities even more valuable.

If animals are selected for breeding which can make the best time for a mile, we think the tendency will be to depreciate the value of the breed. Bred for that one 
purpose, they will lose some of their compactness, become more leggy and "rangy," and lack the stamina of the true Morgan. The general business qualities of the Morgan are what give him his great value. His admirable travelling gait, and his stoutness, courage, and endurance, are what is wanted for the road. It is not wise, therefore, to attempt to make him the fastest horse in the world, for in doing this we shall be very likely to lose sight of qualities far more important than the ability to trot a mile in $2 \mathrm{~m}$. 30s.

Let those breeders who manifest so much anxiety to produce a horse that can trot his mile "in the thirties" consider for a moment what would be the result, could they realize their utmost expectations; (and, if their ex. pectations are not to be realized, it is foolish to entertain them.) The horse that can now trot his mile in $2 \mathrm{~m}$. 30 s., does he command a great price because that speed is avaiiable for any practical and ordinary business purpose? By no means. It is because he can out-foot nine-tenths of the sporting horses of the country. . It is because his speed is relatively great, that his.value is great, and just in the proportion that breeders could produce such animals would their value be decreased. This alone should cause the prudent breeder to look first for those qualities that will render the horse valuable for all ordinary business purposes.

No person who has given the subject any attention, but must be fully convinced that too little pains and care have been taken in breeding these horses. The value of Morgan horses was not at first justly appreciated by our own people. Travellers through the State had observed their fine points, and had noticed their 
great power of carrying weight in the stage-eoaches, and their extreme hardiness of constitution in a great variety of situations. A few of the shrewdest horsemen saw that they were destined to be in great demand whenever they became fully known; and these few took pains to secure some good stock for the purpose of breeding. In that part of the State where they were first bred they became quite numerous before much demand for them sprung up. The farmers did not dream that the supply was exhaustible, and little attention was at that time paid to breeding horses, as they were very low, and farmers generally considered it unprofitable. In this State, when the dealer in horses, or a stranger, offered the farmer at first $\$ 100$ or $\$ 125$, and at a later period $\$ 150$ and $\$ 200$ for a fine mare, he could not resist the temptation to sell her; and he would supply her place with an animal of far less size, and worth perhaps less than half the money he had received for the one he sold. The legitimate fruit of such a course was the decrease in size and value of the animals raised; and had this ruinous system been generally pursued and continued, the valuable qualities of the breed would have soon been lost. These remarks, however, are chiefly applicable to that portion of the States of Vermont and New Hampshire lying between Newbury and Lancaster on Connecticut river. The reason for this must be found in the fact that here the horses were first bred, and from their greater number were here most easily obtained: consequently, buyers from abroad rarely visited any other part of the State, and thus farmers of the other sections were not so often tempted by liberal 
offers to part with their best mares. Though these remarks are particularly applicable to that part of the country referred to, yet to a certain extent they might well apply to every town. As an illustration of the effect of this carelessness on the part of breeders in relation to the quality of their mares, we would point to the very evident difference in the size of the stock descended from the Sherman raised in the vicinity of Sutton, Burke, Danville, Lyndon, St. Johnsbury, \&c., and that descended from him, but raised in the north part of the State, and in Canada, about Derby and Stanstead, the former coming directly from the Billy Root, and the latter from the Royal Morgan.

These horses possessed exactly the same amount of the blood of the Justin Morgan, the dams of both being sired by the Justin Morgan, and themselves both sons of the Sherman. Their dams also were nearly of equal size. These horses bore a close resemblance to one another in many important points, were nearly of the same size and height, amount of bone, general form, and both possessed extraordinary courage and action. They have both, also, attained great and nearly equal celebrity. Under such circumstances, from the same description of dams, we should expect stock of a very similar character, and equal in most respects. In life, spirit, and action, there is perhaps but little if any difference, the descendants of both being widely and justly celebrated for these qualities, but in size there is a very pereeptible difference. The stock descended from the Royal Morgan, and raised about Derby and Stanstead, averaging decidedly larger than that raised in the other towns mentioned, and descended from the 
Root horse. Derby and Stanstead are much farther removed from the markets where Morgan horses have been sought, and the mares from which the farmers have bred have been much larger.

Though breeders were generally unmindful of the qualities of their breeding mares, yet there were many scattered throughout the State who foresaw that these horses would be sought for, and early turned their attention to keeping up the qualities for which they were so remarkable, if not improving them by judicious crossing with the best mares the country could produce. Some commenced paying attention to this matter during the lifetime of the Justin Morgan, and bred directly from him. A constantly-growing attention to this subject has been manifest from the death of the Justin Morgan to the present time, though the great mass of the farmers of the State are yet most culpably negligent in regard to the blood of the stock they breed from.

It is to these comparatively few persons, who early gave their attention to this subject, that much of the reputation and present excellence of the race must be attributed. With regard to the proper means to be adopted to improve these horses, little has been said by those who have written upon it that we think will be of great service to the breeder. The subject is a difficult one; and, although it is very easy to exhort farmers to take more pains in selecting their breeding animals, and endeavor to "improve" the general character of their stock, yet it is very far from an easy task to indicate the precise points in which any improvement is needed, and the manner in which it is to 
be accomplished; and it is far better to continue breed. ing entirely within themselves, a stock of horses that have proved themselves valuable, than to crass them with animals of a different character with the hope of improving them, without any definite idea as to the nature of the improvement we propose to make.

Although we never saw a horse that came up fully in every particular to our ideal standard of perfection, yet we have seen many Morgan horses that approached it so nearly that we should have little thought of attempting to improve them. Therefore, let the first efforts of breeders be directed to the preservation of the good qualities already obtained, by taking great pains to breed from animals, both sires and dams, possessing as fully as possible the prominent characteristics that have distinguished the race, and whose pedigrees trace back through the best animals of the Morgan breed. Pursuing such a course, the breeder can rely upon reaping an ample reward for his efforts in the ready sale his stock will meet with at remunerating prices; and he will not subject himself to the mortification of discovering, when too late, that crossing his animals with strange breeds, with the view to improvement, has resulted in a progeny decidedly inferior to either branch of the parent stock.

Let it not be supposed that we are averse to, or disposed to discourage, any attempts at improvement; on the contrary, we would stop at nothing short of perfection-but, as we approach that ideal standard, the difficulty of advancing is increased; and the greater pains should be taken to secure the progress already made. The improvement of animals that closely approach per- 
fection, should be attempted with the greatest care, and by persons possessed of a thorough knowledge of the physical laws that will control the result; and such alteration must be undertaken for the correction of a fault, or increased excellence in some definite and clearly-understood point; otherwise such experiments will resemble a lottery, in which, though there are splendid prizes, yet there is also a most discouraging array of blanks.

Vermont breeders have been so often advised by persons from abroad to make every exertion to increase the size of their horses, that, contrary to their own judgment, they have been led to make some efforts to produce such a change; but, so far as we have had opportunity to observe, much increase in size has almost invariably been obtained by a large admixture of other blood, and at the expense of qualities we deem of the utmost importance, namely, compactness, action, and spirit. The word "size," as applied to horses, has a very different meaning at the South and in New England. At the South the most valuable horses are from racing or thorough-bred stock. As races are now generally for short distances, height and length are of great importance, as enabling the animal to take a long stride. Consequentiy, height has there come to be the measure of size. Thus you ask a person how large is his horse, and you are told "he is a large horse, as much as seventeen hands high," or, "he is a small horse, not more than fourteen hands high.' Few horsemen at the South take any pains to ascertain the weight of their horses, that being considered of little importance. Inquire of a Vermonter how large is his horse, 
and he replies, "he is a large horse-he.will weigh 1200 lbs.," or, "he is a small horse, and won't weigh more than 900 lbs." This should not be forgotten, as many persous who have advised an effort to increase the size, intend the word to apply only to the height.

We think a slight increase in height would be advisable; but there is great danger of running into the opposite extreme, and certainly for service and endurance, too much height is a serious objection. Youatt says the breeding mare should have "compactness of form, and shortness of leg." That shortness of limb with compactness of form are indispensable to great endurance, is too well known and too generally admitted by horsemen to need any argument. It may be true that height is necessary to give the greatest speed, but of what practical advantage will be such speed without corresponding powers of endurance. All experience shows that the horse of medium size is far the most capable of performing great feats upon either the turf or road in carrying weight at long distances. The Arabian, universally admitted to possess astonishing powers of endurance under light weight at high speed, is rarely fifteen hands high. Of those horses that have distinguished themselves as trotters, a very large majority of them have been under $15 \frac{1}{2}$ hands, some of the most remarkable of them being under 15. "Fanny Jenks," who trotted one hundred miles in nine hours forty-two minutes, was only $14 \frac{3}{4}$ hands high, and weighed only 935 pounds. Tom Thumb, who performed one hundred miles upon Sunbury common, England, in ten hours seven minutes, in February, 1829, was only 14 hands high, and his 
driver and sulky'weighed 250 lbs.; and we think more instances can be adduced of great feats at long distances, performed by horses under fifteen than over sixteen hands high.

We believe it is a fixed and unyielding law of animal life, that in medium size we shall find the greatest activity, the best constitutions, the greatest power of endurance, and the most courage and vital energy. In the human race, how strikingly is this law illustrated! It is the men of close, compact figures, and medium height, that possess the best constitutions, and are most active and enduring. The athletie of the amphitheatre are men of medium size, with close, compact, muscular figures. Mark the men who live to the age of ninety or one hundred years: they, too, are of medium stature, with swelling chests and close-lznit, vigorous forms.

Large cattle are slow in their movements, and the heavy Durham or Herefordshire cannot compete with the low, compact and hardy Devon in action, speed, and endurance. The largest varieties of the dog are quickly conquered by the small, but active and vigorous terrier. And the tall, heavy Chinese fovls are speedily overpowered by the smaller, but nimble and high-tempered game bird.

The horse is not an exception to this general law; and the breeder who fancies he can produce a class of tall, heavy horses, possessed of the activity, the endurance and nervous energy that belongs to animals of a smaller size, will find upon trial that he has underrated the difficulties of the undertaking. The Morgan horsc has obtained his present celebrity as the best 
business horse of the country, notwithstanding the cry "too small, too small," and we earnestly exhort oreeders to beware, lest, in endeavoring to increase the size, they lose the very qualities that have earned for him his high reputation. Nor is it wise to breed from horses below the medium size. Very small horses are unable to carry the weight or perform the service required, and will prove dull of sale. But, aiming to produce animals neither overgrown or dwarfish, by breeding from such as are of medium size, the breeder can safely rely upon a quick market and remunerating sales. -

It may be said that the breeder must labor to produce such horses as the market demands. 'This is very true. But if it is true that a horse of a certain form is best adapted for the uses to which horses sold in market are put, although he may differ from the horse then in gencral use, he will not fail to be properly appreciated when fully known. In a former chapter we stated that we considered fourteen and a half to fifteen and a half hands about the proper height of the business horse, and the Morgan horses of the best blood will fall a little below that standard. We would, therefore, recommend that pains be taken to bring him up to this standard, but not at the expense of any of his valuable qualities.

The proper method of attempting this improvement is to seleet larger mares. They should not be of disproportionate size, but such as are fully up to, and if possible a little above the present average height; the sire should not be larger than the dam. The most intelligent breeders are agreed it is an important rulo 
in breeding, that the dam should be fully equal to the sire in size. Fet certainly there is no rule more frequently disregarded. Upon this point alrnost all writers are fully agreed. Sorne advise breeding mares of large size to sires of small size; this we should ver; much prefer to the opyosite course; but our own opinion is, that there should be an arproximate equality between the sire and dam, taking care that the sire be not the largest, and that he possess such qual. ities as we hare before described.

But some will say recourse must be had to racing blood to improve the present Morgans. If the char. acteristic qualities of the Morgan horse are really val. uable, we are at a loss to see bow bis excellence in these respects is to be increased by croseing him with the race-horse.

Where breading mares of Morgan blood cannot be cotained, re should. prefer rnares possessing a strain of racing-blook, bat not thorough-bred: for though the thonough-bred maj oscasionally be found with considerable oompactness of form, yet it can bardly be denied that a cloze-buit, compact racer with plenty of bore and muscle, is at this day a rare animal. Still, he retains in a high degree the fire and courage that his anceztors brought with thern from the deserts of Arakia.

It is to the thorcugh-bred that the Morgan orres, in a great measure, his indomitable courage and nererLagring epirit. This courage and spirit every good tregder will talie grent pains in foster and preserte. Compamtively few breeds of horses possess in a bigh degree this distincuishing trait of the Arabian; and it 
is chiefly for this reason that we would resort, when Morgan mares cannot be obtained, to those that have a strain of racing or Arabian blood, say one-eighth to one-quarter.

In the breeding of all domestic animals except the horse, competition for the purchase of the best stock is mainly confined to farmers and breeders. But the best specimens of the horse are daily sought for, and tempting prices offered, by persons not engaged in their production, residing in the great cities, who are proud to own the finest drivers and goers in the country.

With the view of improving the horses of France, the French government maintain a stud of the best stallions and mares for breeding, and no expense is spared by them to command the best in that country. In some parts of the Uuited States associations of farmers and breeders have been formed for the same general purpose. It is to an association of this kind formed some years ago, that Kentucky is indebted for her fine stock of high-bred cattle, which are acknowledged by those who have had the best opportunities of judging, to be superior to those of any other State in the Union. The Kentucky asssociations have usually imported their animals, and from time to time sold to their own citizens, who would retain the stock in the State. The stock sold has usually paid for the original cost, and all expenses, so that the improvement has been made at a cheap rate, and the stock is constantly improving.

Some liberal gentlemen of fortune, who are neither farmers nor breeders, would no doubt aid in forming and keeping up such associations for the improvement of horses. If such an association were formed in every 
county, they could easily retain the best stallions and rnares for breeding. They would prove useful in awakening more attention to the importance and necessity of retaining the very best animals, and the example of the association would not be lost on individuals. The following suggestions by an intelligent writer in the "Albany Cultivator," over the signature of "Equus," seem to us worthy of attention: "The formation of clubs in different neighborhoods for the improvement of the breed of horses, might be productive of great advantage. It should be an object with such clubs to secure the best mares, which should be bred to the most valuable horses. The rules of the clubs should be as few and as simple as possible. The mares may be owned separately, by individuals composing the clubs; but they should be such as the club, or a committee appointed by it, should approve. The stallions should be owned by the club. They should be selected by individuals appointed by the club. The club should have the sole direction in regard to their use; they should be kept at joint expense; and the proceeds arising from their services should be divided in an cquitable ratio among the members. This business, if properly conducted, may undoubtedly be made profitable. The clubs, if properly conducted, would soon establish a favorable reputation. They should offer none but the very best stock, and such would be certain to mect with a ready sale at remunerating prices."

In some parts of the country such societies or clubs have been formed-but few if any in our State. In reating the forcgoing remarks in relation to the prop- 
er method of preserving and perpetuating the Morgan breed of horses, it must be borne in mind that wo believe it is the true interest of breeders to foster and preserve those qualities that render them so valuable as business horses, and to make no effort to adapt them to those kinds of service for which fashion or utility demand a different kind of animal. They have not height enough to suit fashionable people in the large cities who want horses to roll their princely equipages through the streets. They have not the natural paces that persons generally think best suited for the saddle; and if we were to attempt breeding horses to supply that demand, we should prefer a different breed.

In concluding this chapter, we cannot forbear expressing the hope that some of our breeders possessing the requisite knowledge of, and taste for the subject, will favor the public with a full and complete essay upon it, as it is one far too little understood by the great mass of our farmers.

The man who causes two blades of grass, or two grains of wheat, to grow where only one grew before, is admitted to be a public benefactor. But he who will improve, or show us how to improve, our domestic animals, will do us an equal, perhaps a greater service. 



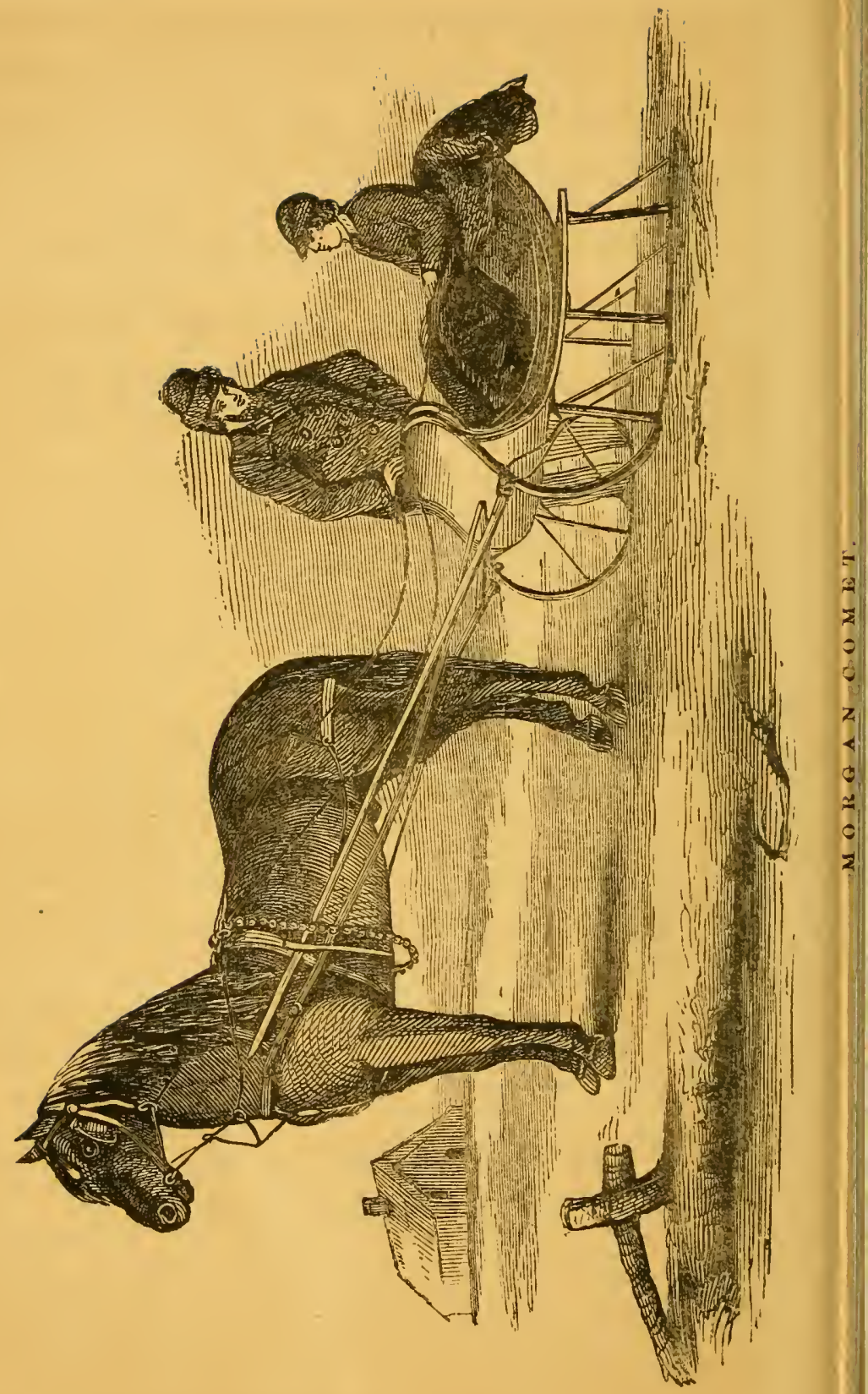




\section{CHAPTER XII.}

HINTS IN RELATION TO BREAKING AND DRIVING.

However horsemen may differ in relation to the manner of inculcating the later lessons, all seem to be well agreed that perfect kindness and gentleness should characterize our first efforts to bring the young colt under that perfect subjection, without which the finest form, the greatest speed, or the most lasting endurance, will fail to make him superlatively valuable. But though all horsemen profess themselves agreed as to the importance of thus treating the young colt, many allow their practice to differ widely from their professions.

Of all the vicious habits which are found in horses, we believe nine-tenths are owing to unkind treatment, harsh usage and impropor management when first put to work, or, in other words, while being broken.

The ancients well understood the importance of kind treatment in training colts. Nearly twenty-three hundred ycars ago Xonophon wrote the following directions for the management of the young horse: "Care must be taken, that when the breaker receives the foal, he bo gentle, tractable, and fond of men. For he is generally rendered so at home by the groom, if the foal is made to understand that hunger, thirst, and irritation are procured by solitude; and that meat, drink and freedom from irritation are procured by men. 
When these things take place, foals not only love but long for men. It is necessary also to touch those parts which, when touched, give greatest pleasure to the horse; and these are the hairiest, and those parts in which, when he feels any pain, he cannot relieve himself.

"The groom should be enjoined to lead him through a crowd, and cause him to approach all kinds of sights and sounds. Whichever of these the foal may dread, it is necessary to teach him, not by harshness, but gentleness, that they are not dangerous."

Regarding this subject as one of vital importance and too little understood, we shall devote some space to it, at the risk of its being thought foreign to our general subject.

The breaking and training of the horse to the kinds of service for which, when matured, he will be used, should commence at an early age. The reasons for this are many and obvious. As the colt advances towards maturity, he becomes more fixed in his habits, more resolute in temper, less capable of being taught, and is able to offer greater resistance.

With regard to his being "less capable of being taught," many persons may not think this correct, and, as an illustration, point us to the horses used in the Circus, these horses being rarely trained to their paces, trieks and evolutions, until they are fully grown; but we do not think this in any respect militates against the soundness of our proposition; it merely shows us how much may be accomplished after the horse has attained his full growth. As a general thing, we think it will be found that those horses whose performances 
are the most remarkable, as exhibiting a high and rare degree of intelligence, were early trained to obedience. It is a well-known fact that animals which have been trained for years, and taught to perform a great variety of tricks, until they seem almost endowed with the intelligence of human beings, are not only perfect in the various dificult feats they have been taught, but they also acquire the power of learning any other tricks or performances with ease and rapidity; just as the child who from his infancy has been taught to exercise his faculties daily until arrived at mankood, acquires knowledge much more easily and readily than he whose mind has been allowed to run entirely to waste and receive no sort of cultivation. The mere habit of implicit obedience from his earliest years, would in itself account, in a great measure, for the greater ease with which the horse accustomed to such obedience is taught.

Few will deny that animals may, and that the horse does, possess intelligence; and we can searcely conceive of an intelligence that is not capable of cultivation and improvement.

When the horse is very young he is capable of offering but a feeble resistance to his master, and there is much less danger of his injuring himself or his trainer by his efforts to free himself from necessary restraint. Two objections are sometimes urged against the early training of colts: 1st, that using them at a very early age retards their growth, and is apt to render them unsound; and $2 \mathrm{~d}$, that early handling injures and sours their temper. To the first we reply that such injuries result from injudicious and harsh treatment, and such 
treatment will result in injuries to the animal, no matter what his age. We have heard this objection made by persons who would allow their colts to run wild until the third winter, never even accustoming them to allow of the least handling, and then an effort is made to break them, and the whole process is emphatically a breaking one.

A file of men surround him in the field, drive him to a corner, and with great trouble a halter is got upon him. He is made fast to a strong post and allowed to wear himself out in his prodigious efforts to escape; efforts that far more imperil his limbs and his life than years of careful and judicious use. Unless great pains are taken that all the fastenings are secure, he will be apt to free himself; and, let him once break away, all after attempts to subdue him will be attended. with tenfold difficulty. After being so far subdued that he will yield to the halter and allow himself to be led, a harness is put on him, he is put with another animal before a common sled, the tongue or pole of which runs so low that the traces are dangling about his legs, and he can at any time siep over them without the slightest dificulty. Me has been put in by main foree, and he stands sulky and ill-tempered, his legs spread out and his ears motionless. When told to start, and the horse with him moves off, he is dragged ahead, and in all probability his first movement will be a prodigious rush forward that threatens to snap every strap and fastening about him; should a trace or a whiffletree break, or any other important thing give way, he will often get loose, and from the effects of such a fright and escape, the high-spirited 
colt rarely recovers; he may, by good management and care, be driven, and even become apparently quiet and manageable; but let some part of his harness break, or a trace unhitch, and he is instantly wild with fright, and will use every possible exertion to escape, which exertion will, in many cases, prove successful. But if, instead of making any effort to free himself from restraint when he is first bid to go, he proves sullen and exhibits a disposition to resist all endeavors to move him, his driver at once declares it an exhibition of illtemper and natural ugliness that must be broken down at the very commencement of his training, or it will grow worse by going unchecked; accordingly he begins with a slight touch of the whip, slight, because he is somewhat afraid of the immediate consequences: startled by the blow, the colt perhaps makes an effort to move forward, but is checked by the bit, the driver having taken him well in hand before touching him with the whip: another touch of the whip with a slackened rein and possibly he is got off without accident. But suppose the first touch of the whip does not startle him, it is repeated until he feels some pain from it, and he returns the blow with a kick, just as he kicks at the fly that annoys him in the pasture; instead, however, of meeting nothing but thin air, his foot or leg comes in contact with the whiffletree, the pole, or the traces-he is both hurt and frightened-he repeats the blow, and in a few moments has freed himself from the carriage, his driver, and all restraint, and has taken his first lesson in one of the worst vices to which the horse can be addicted.

It is true that under such management the colt will 
often turn out well and become perfectly kind and tractable, but it by no means follows that because such management often succeeds it is the best mode of treating the young colt. Such treatment often results in the utter ruin of the animal, by straining him or in. flicting some other bodily injury, or by fixing upon him some vice that renders him wholly unsalable.

Of the animals that suffer permanent injury from such management, nine-tenths of them are horses that would, under different treatment, have made very superior and valuable servants-for it is the horse of high courage and spirit that offers the most serious resistance, and requires the greatest exercise of patience, kindness, and gentle treatment; while the dull, sluggish and stupid animal, though easily broken, is unfortunately worth but a trifle after it is done.

Some may think it impossible that such a course of brutal treatment can be often pursued towards the horse in view of all that has been written upon the subject; but we have so often seen instances of it, that it is quite plain enough has not yet been said or written against it.

In training the young horse, too much pains cannot be taken to have every description of harness or fastening put upon him perfectly sound and sufficiently strong. Accidents arising from defects in the harness or carriage are not only dangerous to the driver, but often ruinous to the horse.

The first lessons in obedience should be given while the colt is following the dam; and, to accomplish this the more readily, the mare should be often used at some light work, in order that the colt may be easily 
handled and made perfectly familiar with the various objects with which, when grown, he will be connected. He should be handled every day gently and quietly, taking care to touch him only in those places that are agreeable to him: these places will be those that he cumnot easily rub, or touch with his mouth or feetsuld as the back, the top of the hips, the jowls, the under side of the neck and the head, taking care to avoid the ears, for few horses like to have their ears touched, no matter how carefully. The greatest care should be taken to avoid touching them on the flanks, or the inside of the stifle, the under side of the breast, or in any place where it seems to annoy him.

Every one has observed that some persons are more easily tickled than others, some being so sensitive in this respect that the mere pointing of a finger towards them puts them in perfect misery; while others hardly ever experience any such sensation, no matter how much effort is made to produce it. The horse is equally sensitive in this respect, and many a fine animal has been utterly ruined by a total disregard to this natural sensation, over which the horse has no control. How often do we sce the horse tied up to be groomed. twisting and turning in every direction to avoid the sharp teeth of the curry-comb with which the brutal groom is harrowing up the skin, and chafing him in those places where even the slightest touch puts him in agony: should the poor brute venture to return such usage by a kick, a most unmerciful beating is pretty sure to follow, and he is at once pronounced an ugly and vicious animal.

When the colt is about two months old, a halter $10 \%$ 
should be put on him: a rope one will do, though a leather one is better, as the harsh rope chafes and annoys him. Of whatever material the halter is made, it should be abundantly strong, so that his most violent struggles cannot break it; put a harness on the mare, and either put her before a wagon, or hitch her in such a way that the colt will not be liable to hurt himself in plunging, as he will be pretty sure to for a few minutes. If he has been accustomed to being handled, no difficulty will be found in putting on the halter. It should be fastened to the collar of the mare's harness, and the breaker, taking hold of the bit of the mother with one hand, keep constant hold of the halter of the colt with the other; for it is imporiant that he should not only surrender, but he should be made to associate all ideas of obedience with his master. After a few pulls at the halter and a jump or two, he submits, and may soon be led anywhere with perfect safety.

In these, as in all other lessons, care should be taken to reward every act of obedience by a gentle pat and a kind word. After the colt will suffer himself to be led, little more need be done towards breaking him until he is two years old, except that he should be handled daily and often led; and in doing this care should be taken not to endeavor to walk faster than the colt is naturally disposed to. It is a great mistake to suppose that incessant lugging at the halter will teach the colt to walk fast: it will only teach him to hang back upon the halter, and this habit, once confirmed, can never be fully broken. At two years old the breaking to harness and saddle should commence. 
If the colt has never been accustomed to the confinement of the stall, he should be put in for a few hours every day for a few days, hitched short so that there may be no possibility of his getting his feet over the halter; he should be turned out nights till he gets perfectly well accustomed to his stable. During this time he should be bitted every day; at first he may be turn. ed loose with a headstall or bridle on, without the reins; this should be continued till he becomes perfectly accustomed to the bit.

The ordinary bitting bridle may then be put on, and the bearing and side reins taken up just so as to move the head a very little from its natural position, and it should not be kept on more than two hours. Nothing can be more pernicious than the practice of straining the head into an exceedingly unnatural position, and keeping it so for hours, to the excruciating torture of the animal, and the utter ruin of his mouth.

Much of this ill-treatment in bitting is to be attributed to a mistaken notion that the minner in which the horse carries his head will depend principally, or in a great measure, upon the position into which it is drawn by the bitting bridle. The position in which the horse carries his head in harness will depend almost entirely upon his form and his temper, which govern its natural position when left free from any sort of restraint. No art can ever give the horse with a low, perpendicular shoulder and short neck, a fine style of carrying his head and neck, even if he possesses good courage and spirit. The bitting bridle may be of some service in giving the head a proper position; but the great object of using it is, to accustom the horse to submit to the press. 
ure of the bit, and teach him to obey the motions of the reins.

When the head is strained up into an unnatural and uncomfortable position, and kept there a long time, the colt relieves the pain he feels by resting the entire weight of his head on the bit; and in this case, instead of deriving any benefit from it, his mouth is injured by his acquiring the habit of hanging on the bit, and often this will be accompanied by the habit of leaning his head on one side of his bit; these habits will follow him through life, and very materially injure him.

Youat says, "The bit should be large and smooth, and the reins buckled to a ring in the side of the pad. There are many curious and expensive machines for this purpose, but the simple rein will be quite sufficient. It should at first be slack, and then be gradually tightened. This will prepare for the more perfeet manner in which the head will afterwards be got into its proper position, when the colt is accustomed to the saddle. Occasionally the breaker should stand in front of the colt and take hold of each rein near the mouth, and press upon it, and thus begin to teach him to stop and to back on the pressure of the rein, rewarding every act of docility, and not being too eager to punish occasional carelessness or waywardness."

After having become well accustomed to the bit, portions of the harness should be put on slowly and carefully, and he should be led about for at time until he becomes perfectly accustomed to it. Then the reins may be used, and when he has become obedient to them, a third person should take hold of the traces, one in each hand, taking care that they are long enough so 
that he can retain his hold if the colt should kick, and by occasionally pulling on them teach the colt to keep steadily along, whether he feels any draught on his shoulders or not.

After the colt has been thoroughly practiced in all these exercises until he has become perfectly familiar with them, and quiet in them, he can be put into a cart or sulky. This should be light, with high wheels, so that the shafts (which should be very strong) may come up fully as high as the stifle. The best place for doing this is an open, smooth field. To put the horse before the cart or sulky, three persons are required-one to hold the colt while the others, each taking hold of one of the thills, draw up the carriage behind him, and, shoving forward and raising the thills, hitch up the traces as carefully but quickly as possible. This being done, the driver should get upon the seat, and taking the reins, allow the person holding the colt to lead him a few rods until he takes no notice of the carriage. He should then carefully relax his hold and give him up to the sole management of the driver, who should make little effort to rein or guide him, but simply hold him snug enough to keep in a walk-for he should not at first be allowed to trot; this exercise should be short, but should be repeated every day. Many will prefer to put the colt beside another horse, but we much prefer this method for several reasons, first-although he may be taught to go quietly with another horse, still he will not drive well alone without a new course of instruction. In almost all double carriages the pole runs so low that the colt can easily kick over the traces; and, should he happen to get over them, he is frighten- 
ed, and it is often very difficult to get him quiet, or prevent his breaking away. In double harness the colt can at any time free himself from the restraint of the bit by stopping and allowing the strain of the reins to come upon his mate. If a little vexed, he can twist about, throw his head over his mate's neck, and do many annoying things that he cannot do in the sulky or cart. Nothing now remains to complete his education but to teach him his paces; and this, although rarely much attended to, is of the greatest consequence, as on his perfection in these depends much of his usefulness and value.

No pace is of so much importance to the roadster or business horse as the walk, and the young horse should be thoroughly drilled in this before any attempt is made to push him in the trot.

The greatest care should be taken to keep each pace clear and distinct from the other; when walking, he should never be allowed to trot a few steps and then commence his walk again. In the ordinary training of horses very little attention is paid to this, and the result is, it is a very rare thing that a horse will bear the least urging, while walking, without breaking at once into a trot. When trotting, as in walking, care must be taken that he keeps steadily at his pace and not slacking into a walk for a step or two; and be not over-anxious to have your colt acquire a reputation for a fast trotter, before he has learned to move well in a walk or a moderate trot. However, he must occasionally be pushed to his extreme speed in the trot, but he should be kept up to it only a few moments at a time; and whenever he has done well, take care to let him 
walk a short time, and reward him with a kind and soothing word. In driving, always keep the reins snug, no matter how gentle the horse, or how slow his pace; the gentlest horse may sometimes be frightened, and the slowest will sometimes stumble. To drive with the reins dangling about your horse is a careless habit, and your horse at all times needs a gentle pressure on the bit. When pushed to the top of his speed he should be kept well in hand, and the reins kept up snug, that he may learn to bear well upon them, as it is by means of the reins chiefly that the horse, when going at a high speed, is kept sterdy in his pace. While it is important that he should take a good snug rein, he should not be taught to pull with all his might, for then he is not only difficult to manage, but the tremendous pull is apt to draw in his nose, and by thus bend. ing the neck too much, prevent his breathing readily and freely.

The art of driving well, however, can no more be taught by any written instructions than the art of writing: we only intend to state a few plain and simple truths that every one who is attempting to break a young colt should know and understand.

Comparatively few persons besides the professed jockeys, fully understand the art of developing the greatest speed of the horse in a trot, and it would be utterly impossible to describe how the driver may discover the first evidence of a break, which may generally be noticed several steps before the break occurs: still more difficult would it be to describe the manner in which the finished driver, by a word and a strain upon the reins, fairly lifts his horse over the trouble. 
some point, without the least apparent check to his speed. Yet almost any man who has any taste for a horse can do much towards improving him in this respect. A great deal will depend upon the temper and life of the horse. The horse of dull and sluggish temper will bear to be crowded with the whip, and when he breaks, may be more severely punished than the horse of high spirit; the latter rarely needs any urging to send him at once to his best speed, but that very ardor renders him much more likely to overstep his gait. He must not be punished severely for every breaking from his gait, for, if he is invariably beaten for it, when he finds he is beginning to get "tangled" he is frightened, and immediately breaks, and having once broken, it is very difficult to get him down to his work again.

Though particularly true of the young horse, that he should be kept at the top of his speed but a short time, it is also true of the older animal. He should be driven daily at a moderate pace, two or three times a week, giving him a sharp drive of two or three miles, not all the way at the top of his speed, but at a good smart gait, occasionally erowding him to the utmost stretch of his powers, but in no case should it be kept up till he begins to flag and fall off in his pace. It will also be found advantageous to drive him over the same ground frequently, until he becomes well acquainted with it, and rouse him to exertion at the same points; by doing this, he will, if possessed of any spirit, soon acquire a keen relish for thesc "bursts." Care must be taken that while endeavoring to develop the greatest power of the horse in the trot, his other 
paces are not neglected; particularly should great pains be taken to accustom him to a good driving or road gait, and to teach him to stand quietly and patiently whenever and wherever stopped, until bidden to go. The latter is often a difficult lesson, and requires the greatest patience on the part of the trainer, and even with his utmost skill and perseverance he will find some horses whose temperaments are so nervous that it will never be safe to leave them unfastened.

During all this course of early training, it must be constantly borne in mind that the colt, although old enough to learn how to move well in harness, and perhaps to drive as quietly and pleasantly as an older horse, is not old enough to perform the work of an animal fully matured. Two or three miles a day before a sulky or very light buggy at a walk, is ample work for him when two years or thirty months old. This exercise should be gradually increased as he grows older, until at four or five years he can be put to ordinary work; but he will not often be able to endure severe and constant labor until six or seven; and we believe it is the general opinion of sporting men that the trotter, if properly treated, will continue to improve until ten or twelve years old, if not prematurely put to severe work.

In this connection, a few remarks as to the proper manner of preparing horses for, and exhibiting them at Agricultural Fairs, or upon other public occasions, may not be arniss, especialiy when we consider that the entire neglect which many really fine animals so often meet with at these exhibitions, is frequently due entirely 
to the ignorance, gross carelessness or neglect of their owners.

A farmer has a fine, powerful three-years-old colt, that is descended from excellent stock, and is in fact. a fine animal, and he concludes to exhibit him at a neighboring Fair; he has been partially broken to lead, but, with this exception, is entirely untrained; he has been left in the pasture entirely to himself; he is in high condition, but his flesh is soft from green feed and want of exercise; his mane and tail are matted and rusty, and his coat looks faded and dry from long exposure to sun and rain. But his owner says the judges should look at the horse and not at his training, or grooming, and appears to forget that the capacity of the horse to receive instruction is one of his valuable qualities, and this capacity cannot be shown save by training. And how shall we know whether his harsh, sunburnt hair can ever look soft and glossy, even with the most careful grooming?

Even if these things could be determined, such a horse would never compare favorably with one which, though by nature in no respect superior, is yet equally well formed, and has been properly groomed and urained. We should no more expect a man of taste would fancy such an animal, than we should expect iim to be fascinated with a beautiful woman, of awkvard manners and untidily dressed.

All horses intended for exhibitions, at which they will require to be exercised, either in harness or under the saddle, should have at least two weeks' preparation, in order that they may appear to the best advantage; 
supposing them to be in good flesh, and healthy at the time this preparation commences. If it is intended to test the speed or endurance of the animal, he should be treated in the same manner as the race-horse is prepared for the course, and the preparation should commence much earlier. If, on the contrary, it is contemplated only to exhibit his form and paces, and give him moderate exercise throughout the clay, much less pains need be taken.

The horse should have a cool, airy, and roomy stall, and should be kept covered, if in summer, with a light, and if in winter, with a heavy blanket. If he is very fat, his flesh should be reduced by decreasing his feed and increasing his exercise; for no good horseman will be pleased with an animal whose muscles are entirely concealed by huge masses of fat; and it is a great mis. take to endeavor to exhibit horses and hogs in equal condition.

If your horse is in suitsble flesh, and is fully matured, he should travel not less than six or cight miles per day, be thoroughly cleaned morning and night, have a liberal allowance of good sweet hay, and just grain enough to keep him in the right condition. If his exercise is six miles per day at a moderate rate, from four to six quarts of oats will usually be sufficient; should he make flesh under this treatment, his feed should be decreased, and his exercise increased, enough to counteract this tendency to take on flesh. The horse may be put to any light work if it is convenient; but if his exercise is continued through most of the day, he will require much more liberal feed. If the owner has no work for him, or is anxious to have his horse make 
a fine appearance, he will do well to have him take his daily exercise in the manner he will be exhibited, whether in the wagon, sulky, or under the saddle, in order that he may appear easy and well accustomed to it. Sufficient exercise is not often given, but it is of great importance. Without it, the horse is nervous and excited, from being brought into a crowd after long confinement to the stable; his flesh is soft, he frets, perspires freely, the dust sticks to him, he soon looks like a coach-horse at the end of a long, hard stage, and, before the day is passed, is quite exhausted by his unaccustomed exercise.

In exhibiting your horse, do not attempt to assume the character of a jockey, for in the great majority of cases the attempt will prove a failure; and should you succeed, we think you will not find the character more creditable to you than that of a sound practical farmer or breeder. Not that we believe there is any moral or religious principle-any rule of social clutyor any reasonable consideration that forbids a person owning the finest horses, and exhibiting upon suitable occasions, and in a proper manner, their form and paces to the best advantage, displaying skilful horsemanship in the management of them; but, in our judgment, it is not in good taste for any one, either in public or private, to attempt to assume a character not his own.

How often do we see youths, aspiring to the distinction of being called "fast," driving round the rings at our Agricultural Fairs, pulling, like John Gilpin, upon a horse who perchance needs most diligent persuading to trot a mile in four minutes, and wornding all sensitive ears with yells and shrieks that would shame a 
Bedlamite; as if the art of driving consisted in pulling with might and main upon the bit, and screaming at the utmost pitch of their voices.

How would such men as Woodruff, Wheelan, Peabody, or Pfifer swell with indignation, were they to be present on these occasions, and see their art thus grossly caricatured. 


\section{CHAPTER XIII.}

TIE PROPER MANNER OF FEEDING AND DRIVING UPON THE ROAD.

Is the preceding chapter, we have offered some suggestions as to the proper method of teaching the young horse to submit cheerfully and fully to the authority and direction of his master, and also as to the best manner of driving. These last had particular reference to the proper manner of driving, to render the management of him easy, and to exhibit his form and paces to the best advantage. What we say upon the subject of driving, in this chapter, has special reference to the manner of regulating his speed over the unequal surfince of the ordinary roads of the country, supposing him to be thus driven daily, as upon a journey or in the stage coach.

With regard to the kind of food that should be given the horse when used upon the road, there is much difference of opinion, some preferring corn, some oats, and some meal, the latter to be fed with the hay after the hay has been cut fine and moistened with water, and is called "cut feed." The meal used is gencrally a mixture of corn and oats, corn and rye, and sometimes of corn, oats and rye. Then of corn and oats, it is usually of about equal parts of each, but the rye, when used, is gencrally mixed with about double its quantity of the other grains. Without stopping to discuss the chemical analysis of these grains, 

and deducing therefrom their relative value as articles of food, we shall content ourselves with stating which, in our opinion, will be found, under ordinary circumstances, the most profitable. Leaving it to the chemist to decide which will produce the most fat, and which the most muscle, we would suggest that this should not alone determine our choice-for when put to rapid work, the horse must not only have nutritious food, but it must be such as will digest readily, in order that digestion may be performed as much as possible during the hours of rest. Driving the horse rapidly when his stomach is filled with undigested food, is not only injurious, but dangerous. Again, sudden and entire changes in diet are decidedly injurious; and if a person, when travelling, endeavors to use a kind of food that is not easily and readily obtained at the various places where he stops to feed, he will frequently be compelled to give his horse a kind of grain to which he is altogether unaccustomed. In those parts of the country where barley is raised, we should use it, preferring it to any other food, provided the horse is not driven very rapidly; but as in most sections of the country barley cannot readily be procured, we should recommend oats, as they are not only excellent food, but can be almost everywhere obtained without difficulty.

As to the quantity that should be fed, no definite rule can be given, as the quantity must be varied to suit the wants of different animals. From eight to sixteen quarts, and usually from ten to tivelve quarts per day, will be found sufficient.

Where ground oats (oatmeal) can be had they are 
always to be preferred, as they are sooner digested. The feed, whether oats or oatmeal, should be moistened with water, as this makes it more grateful to the animal, ficcilitates digestion, and it is thus more easily and thoroughly masticated. This should be given regular, and not more than three feeds in twenty-four hours. The largest should be given at night, and the lightest at noon, unless the horse is allowed from two to three hours rest, in which case the noon feed may be in. creased. In no case should either water or food be given when the animal is very warm from exercise.

The first and most important duty that the traveller should in no ease neglect, is to look personally to the care of his horse, to see that he is properly fed and watered, that he is put in a comfortable stall, that he is well groomed and well littered. The man who considers the care of the horse he is driving unworthy his attention, or who from carelessness neglects it, ought never to leave home unattended by some person whose dignity will not suffer from attention to the comforts of his faithful scrvant, and who is sufficiently thoughtful to recollect them. This care of the horse is not only demanded by every principle of humanity, but also by regard for our own interest, since no horse, however sound and enduring, can last long under suvere labor without constant and judicious care. It is hardly necessary for us to say that the fact that the animal is a hired one, in no way lessens the duty, but rather seems to increase it. The man who fails to take suitable care of a hired liorse is not ouly wanting in humanity, but he cannot properly set up any great claim to thorough honesty, for he is neglecting an ani- 
mal that is endeavoring to serve him, and wronging his owner out of part of the consideration for its services.

Again, we say to all those who have occasion to travel on horseback, or in private carriages, put not your faith in grooms and ostlers, for they are fallible, but attend personally to the care of your horse, and be sure you will not repent it, but will find yourself doubly repaid for the little trouble by finding him come out bright, fresh, and vigorous in the morning, his energies renewed, and fully able and willing to serve you.

When stopping for the night, endeavor to secure a good, roomy, and quiet stall, not too close and confined, nor yet so situated that a current of air will blow into it; see that there are no holes in the manger through which he may waste a portion of his food; see that the floor and sidès are strong and sound, and the latter so constructed that he will not be annoyed by animals in the neighboring stalls. Take off the harness and have him thoroughly rubbed. If wet with sweat, whether in summer or winter, do not lesve him until perfectly dry. If the weather is warm and the roads dusty, have the lips, nostrils, and eyes wiped out with a damp sponge; nothing is more grateful to him, and anything that promotes his comfort and rest is of positive service to him.

If the horse has not been accustomed to the harness regularly, or if the harness is one in which he has not been used, examine the various places where it will be likely to chafe him, particularly the shoulders. If the skin is anywhere broken during the first day's 
drive, be sure there is something wrong about the harness that must be at once attended to. If the skin has not been broken, you may judge whether the shoulders have been chafed or "scalded" by watching the drying of the hair. If there are any spots that remain wet after the surrounding parts are dry, it is chafed, and the shoulders should be washed in cool (but not cold) water and castile soap, the soap assisting in cleansing the skin, thus opening the pores and promoting a healthy action. Some horsemen wash the shoulders every night, but we do no think it generally necessary.

Before putting him in his stall, have any old hay that may be in the rack or manger taken out, and the manger or box in which he is to have his food cleaned. If you have driven him hard, or if he is warm, dio not feed him for half an hour. If he is very dry, give him three or four swallows of water, not very cold. In half an hour, give him six or eight quarts of water, and a little bright, clean hay, free from mould or dust. In the course of an hour offer him more water, and give him his allowance of grain and more hay. See that he has a good, ciry, deep bed, for the horse enjoys a good soft bed, after a hard day's work, as well as his master. Having thus seen him properly cared for, leave him to rest.

The following morning do not feed him, or any way disturb him until sumrise, or at least until after daylight. The horse, unless very tired, rarely lies down until after midnight, and does not require more than from three to five hours sleep, and this he will usually take during the latter part of the night.

The first thing in the morning should be to sce if 
he has eatrs up all the feed given him the night before. If not, he should be fed sparingly, taking care to remove all the hay and grain that he has left of his last night's feed. Before feeding, offer him a little water. If he drinks freely, and eats with apparent relish his morning's allowance, you may safely conclude that he is well, and that his previous day's drive has not injured him. If he has been properly groomed overnight he will want nothing more than a light brushing, and in an hour after he has eaten his feed he may be harnessed and commence his day's work.

With regard to the proper method of driving, no rules can be laid down that will enable an inexperienced person to drive well, practice being as necessary to enable one to drive well as to write well. Still, some general rules can be given that will be of service to the new beginner.

With regard to the rate at which the horse should be driven, little can be said, as this should depend on a variety of circumstances, the speed of the animal, his powers of endurance, the distance to be travelled, and the urgency of haste in the business for which the journey is performed.

Supposing that there is no extraordinary necessity of haste, and that the journey is to be continued for several successive days, care should be taken not to push the horse the first two or three days, but let him get seasoned and accustomed to his work. If worked too hard the first two days, he refuses his food, becomes dull and stupid, loses flesh rapidly, and in a short time, if he is not dangerously sick, he is entirely unable to work. 
Whatever ciistance you intend to drive in the course of the day, drive moderately for the first hour; many a fine horse is ruined by being driven fast on a full stomach. After the first hour, consider the distance you have to go, and the time you have to accomplisn it in, and endeavor to drive at an equal rate. Not that you are to drive at the same rate up hill and down, or drive each mile at exactly the same speed, but sup. posing the general character of the road to be the same through the entire distance, endeavor to drive an equal number of miles per hour.

Thus suppose you have sixty miles to travel, and have nine hours to perform it in, drive thirty or thirty. five miles at the rate of eight miles per hour, then stop for an hour, or an hour and a half, to give him food and rest. Take off the harness and have him rubbed with straw until he is dry, or at least until the dust and sweat are removed, then give him a little water and his grain. We are aware that most travellers do not remove the harness at noon, but it should always be done, especially in hot weather.

Too much time must not be spent in rubbing and cleaning, and as soon as sufficiently cool, the horse should have his feed, for this and rest he needs more than grooming. . Before starting in the afternoon, offer lim a little water. Drive as in the morning, except that there is less need of caution for the first hour, and you may drive at the usual speed for the entire remaining distance.

We are aware that it has been sometimes recommended to pursue an entirely different course, namely; to drive at a high speed for a few hours, and then give 
the horse a long rest, and again drive at the same high speed for the balance of the distance. Thus, in performing a distance of sixty miles in nine hours, they would drive thirty miles in three hours, stop three hours, and drive the remaining thirty miles in the remaining three hours.

This advice would seem to be founded on the belief that it is the number of hours which a horse is worked that fatigues him, without reference to the speed; indeed, we remember to have seen this principle broadly and distinctly stated, that "it is the all-day work that knock up horses, and not the rate at which they are driven." This seems to us a great and palpable error.

Let us consider for a moment what is the average rate of speed of the race-horse during the entire time occupied in a repeating race of four miles. Take, for instance, the race over the Union Course, Long Island, for the Jockey Club purse of $\$ 600$, October 13, 1832. In this race twenty miles were run in $41 \mathrm{~m}$. 40 s. actual running time, but allowing thirty minutes between each heat, which is the shortest time allowed for cooling and resting the horses, and the total time occupied in running the twenty miles was $2 \mathrm{~h} .41 \mathrm{~m}$. $40 \mathrm{~s}$., or a little less than eight miles per hour. A good hack or livery horse would do this, and show few signs of having been driven. It may be said that this is an extreme case; very true, but having shown that our theory is correct in this case, may we not properly claim that something more than simple assertion is necessary to establish its unsoundness, in cases where the speed is indeed less, but the distance greater. But 
we need not rest the question here, there are striking illustrations of the soundness of our theory; that the distance and time in which it must be accomplished being given, every portion of the distance should be accomplished in a corresponding proportion of the time, nights and the necessary time for giving one feed at noon being of course excepted.

The truck horses in the cities are worked all day and every day, in rain or sunshine, yet how much better their condition, and how much longer they last, than the city livery horses. The latter are driven but a small portion of their time, but are driven at a high speed. The stage-driver who rushes his team over one half the road, and walks them over the remainder, will never make "good time," for his team cannot make up by high speed the time he has idled away on the road, or at his stopping places, and the appearance of his horses will bear ample evidence that the attempt to do so has been injurious.

The great art of driving horses long distances at good speed without injury, consists in keeping them steady at a given pace without fretting or worrying them, restraining them when inclined to go too fast, urging them when necessary, and doing either without annoying them. Other things being equal, the horse who does his work in a quiet steady way, will last much longer than the one which frets and is restless.

If your horse is high tempered, and inclined to travel faster than you think best for him, you cannot take too much pains in starting him easily and quietly. If he takes hold of the bit and is inclined to push off at too high speed, keep a firm but steady pull on the 
bit, but you must rely principally upon the voice to quiet him. Speak to him in a calm, gentle and soothing tone, and you will be surprised at the effect it will have upon him. There are but few horses which will not settle quietly into a walk in the course of half an hour, under mild and soothing treat ment. If your horse is a little dull, and needs urging, drive him with a constant, though gentle pressure upon the bit. When he needs urging, speak to him in a tone that he will not fitil to hear, and enforce instant and prompt obedience with the whip. Be careful not to urge him by speaking to him when you do not intend to insist upon his prying attention to you. Never use the whip for any other purpose than to punish the loorse for not minding you. Nothing will sooner perfect a liorse in dulness and stupidity than constant tapping with the whip, and constant urging with the voice; he-soon gets so accustomed to both that he cares nothing for either, and the most vigorous twitching of the reins-the most authoritative commands, and the most industrious though mild applications of the whip, result in nothing but a slight frisk of the tail or a gentle toss of the hend. Although the greatest art in driving upon the road consists in driving at the required speed without fretting the horse, the knowledge of the proper time to urge or to restrain him is almost equally indispensable. This, of course, will depend upon the smoothness of the road, the ascent or descent of the ground, and the weight carried; much will depend upon the animal.

Owing to difference in form and gait, some horses that climb hills with difficulty can descend them rap- 
idly and easily, and again others prefer to walk whereever the ground descends rapidly, but will trot up ordinary hills to the very crest with little apparent effort. This difference in the form and gait of the horse should be constantly borne in mind, and he should be allowed to go slowly where it is evidently dificult for him to move fast. As a general rule, the horse should be made to walk wherever the ground ascends or descends rapidly. If driven rapidly up steep bills, he is almost exhausted when he reaches the top; and if driven rapidly down, then, it is dangerous to the passengers, because his footing is insecure, and he is liable to fall; and if the practice be continued, it will break up the stoutest fore limbs, by the force with which the feet come upon the ground.

Where the surface of the road is smooth, and the ground slightly descending, the horse should be driven at a tolerably rapic rate, especially if he has a heavy load, for upon this ground the load, whether great or small, will move easily, and when the load is heavy the horse will be compelled to walk up most of the rising ground. When the load is light, and the speed eight miles per hour or more, the horse should be kept at a moderate trot on ascending ground, except up steep hills, for it will distress him less to trot over ground slightly ascending than to walk over such ground, and make up the time by increased speed on the level and descending.

- When the road is rough and uneven, endeavor to shun rough spots. T'o do this well, kecp constant and careful watch of the track, and avoid the bad spots by turning a little before you get up to them, instead of 
waiting until you are close upon them, and then pull your horse out of the road with a sudden jerk, that irritates and frets him, and injures his mouth. It is better to take the jolt, unless it is dangerous, than to do this. After your horse has once become accustomed to turning out for the bad spots, it will be very little trouble to do it, and it will be much easier both for the horse and the passengers.

Did our space permit, we should like to say much more upon this subject, as it is one in which we take much interest; but must content ourselves with the impcrfect directions above given, repeating the remark ire made at the commencement of this chapter, that however full and correct the directions, no one can learn to drive without practice, any more than he can learn to write simply by reading an able treatise on penmanship. 


\section{CHAPTER XIV.}

HINTS TO PURCHASERS OF MORGAN OR OTHER HORSES.

IT is not to be supposed that any descriptions can be written, or any rules laid down, that will give the keen, discriminating eye, the fine perceptions with regard to form and motion, the rapid, searching glance at defects, that the true and practiced horseman seems to realize at the first view, enabling him to form a tolerably correct judgment of the value of an animal almost as soon as he sees it; some suggestions, however, can be made which will aid ordinary purchasers.

Before a man attempts to purchase $a$ horse, he should first determine for himself what kind of horse he requires, both as to size and general qualities, since the value of the horse to his owner depends very much on his adaptation to the kind of business required of him. As to size, we think all experience shows that medium size is the best for ordinary use; such horses we shall find possessed of the most compact forms, the most rugged constitutions, the most nimble, easy, and graceful motions. Though it is very true that a good horse may have a bad color, yet as a bad color is to some, perhaps most buyers, a serious objection, such should be avoided. White, light gray, light sorrel, cream-colored, and spotted, are the most objectionable, 


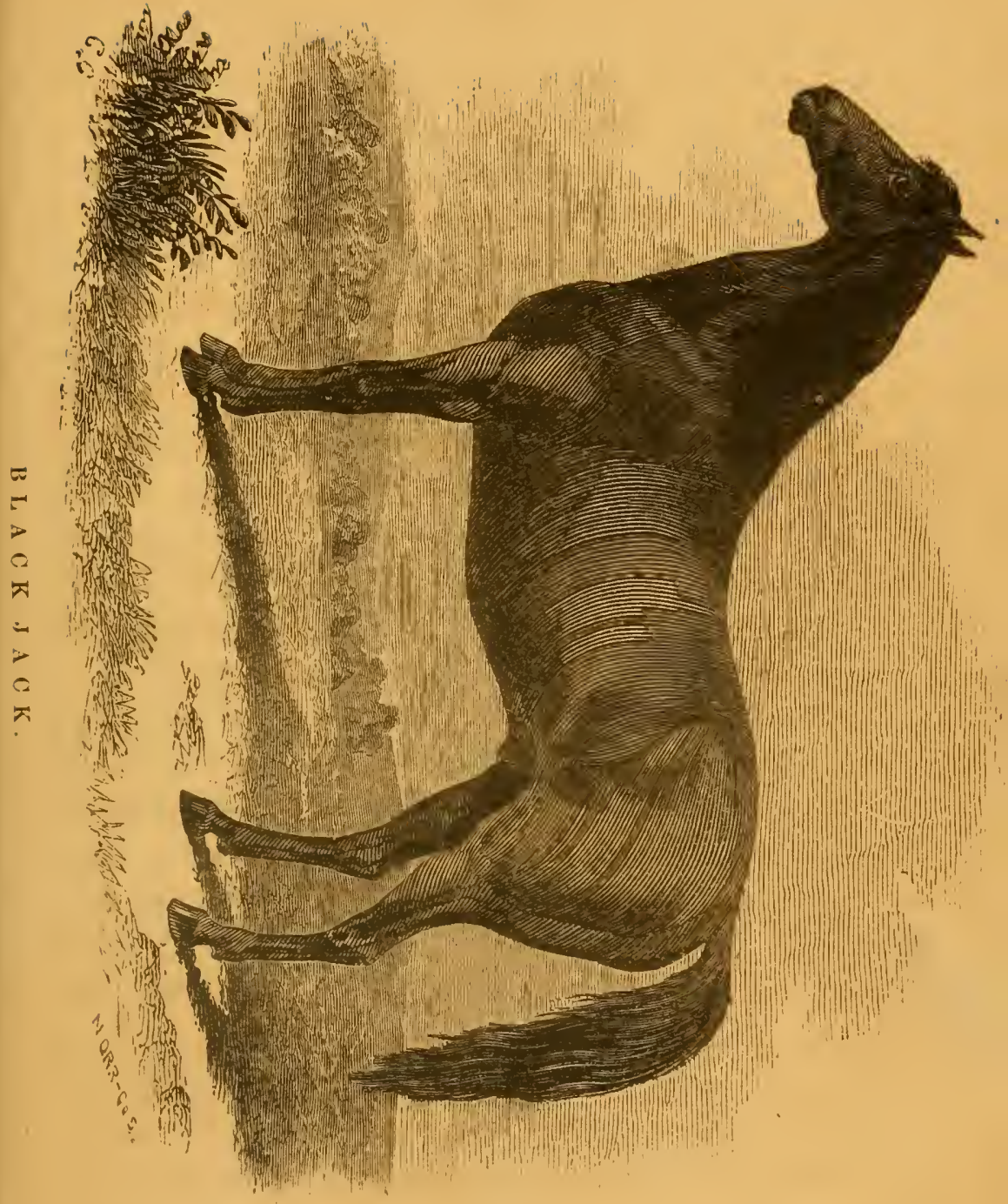



and should be avoided. Bay, chestnut, black, and dark brown, are almost universally esteemed the best, and horses of these colors are worth more in every market than horses of the colors before named.

When the purchaser is unaccustomed to horses, we would advisc him, after having determined what kind of a horse he wants, to engage some one to assist him who has had more experience, especially if he is about to purchase of a stranger, for in the latter case he will not only be liable to misjudge as to the justness of the animal's proportions, but also as to his soundness and vices, for a vast many faults and defects may by artful jockeys be concealed from the inexperienced eye, and sometimes even from the closest and most intelligent examination.

If, however, the purchaser can avail himself of no such assistance, or chooses to trust to his own judgment, he cannot be too cartious or creumspect. IVhen you enter the stable, observe carefully the way the owncr approaches his horse; if, as soou as he comes within hearing, he speaks to him in a loud, sharp voice, that makes the horse spring up in his stall as if frightened, look out for some defect in his limbs. If much lame, it will be seen when he is moved, but if it is very elight, you may not then notice it. If he comes up to the horise very carefully, and seems a little cautious about going into the stall where he is, you may justly suspcet he is not perfectly lind and pleasant-tempered. If he approaches the horse in an easy, careless, but quict way, you may reasonably expect that the horse has no such vices to hide, and you will not suspect him of lameness, though it should not prevent your watch. 
ing carefully every motion of his limbs to see if you can detect it. Mark how the horse stands, how he is hitched, and what kind of a halter he has on. If he stands with one of his fore-feet far in advance of the other, look out for founder. If he is fastened with more than ordinary care, see if you can observe any signs of his having attempted to untic his halter with his teeth. If the halter is fastened very tight round the throat, he may have a trick of slipping it off, or he may be a cribber. A large strap, buckled close round the throat, will often prevent cribbing.

Youatt considers crib-biting unsoundness; and it is, at all events, a very bad habit, that materially injures the sale of a horse. If the manger shows signs of being bitton by the horse, do not purchase the animal until you have seen him eat. The teeth of an old "cribber" almost invariably show signs of this habit, being much worn on the outer edge, but in young horses it will not always be noticed. When the horse is turned out of his stall and faces the light, observe whether he shuns it, and partially closes his eyes; if so, his eyes are weak; if, on the contrary, he looks boldly about, with a bright and lively expression, his eyes are not only good, but you may infer that he is both spirited and tractable. Examine the head carefully. If it is thoroughly good, light, lean, and graceful, with tapering, sharp-pointed ears, ever moving and restless, the eyes animated and prominent, the forehead broad, the muzzle firm, the nostrils large, and the whole well set upon the neck, you may be pretty sure that it belongs to a good horse.

If the eye is not bright and lively, it should be 
carefully examined, especially if the animal is from the Weatern or Southern States, where diseases of the eyes are more common than at the North and East. Sometimes the eye will look very natural, and the horse appear bright and well, yet be perfectly blind. If the horse is entirely blind you may easily detect it, for though some horses move about very easily and handily when perfectly blind, you will soon notice the defect, if you watch him and suffer him to move about freely. If you are suspicious that, although not entirely blind, his sight is defective, you may determine it by passing some small object like a stalk of hay rapidly before the eye, and at a short distance from it, taking care that the substance be not large enough to create any perceptible motion of the atmosphere, for a blind horse will wink at the least unnatural current of air.

The general appearance of the head is a pretty sure index of the age of the animal, and the inexperienced buyer will do well to rely as much upon this general appearance, as upon the appearance of the teeth; for with a saw and a firing iron, old teeth may be made to resemble so closely those of a young horse, as to deceive even pretty good judges. In the old horse the eyes are usually a little sunken, and the hollows over the eyes are deepencd, the lips are less firm and close, nd the month shows the long use of the bit.

If the head is satisfactory, ncxt examine the legs. ee that they are not too long, are wide, flat, bony, and free from flesh below the knees and hocks. When the muscles are well developed, and stand well out from the bone, and are free from any fat or meat, they 
can be distinctly traced by the eye through the skin. See that the horse stands squarely and equally upon them, that they are neither stretched too far apart nor gathered too much under him. Examine closely whether there be any unnatural enlargements or bunches on either leg. If none can be detected by the eye, then pass the half-closed hand carefully down each one, pressing the leg moderately, to determine whether there are any bunches or scars concealed by the hair.

Look carefully at the hocks for spavins, curbs or thoroughpin, for although the latter do not constitute unsoundness, yet they are objectionable. Pass the hand carefully down the back sinews to detect any unevenness in the muscle. If any little bunches are found, or the cord is anywhere enlarged, examine carefully for any scar that may indicate the injury. was an external one. If there are no signs of any such injury, and especially if the muscle at this point feels sore, reject the animal. The back sinews have been strained, if not ruptured, and there is little chance that he will ever be able to endure hard service. Search for bunches on the inside of the fetlocks; if you find them, or scars, you will attribute them to the horse's cutting. If the scars are old, and the horse being in very high flesh, yet travels very close, it will be wise to reject him, for in ordinary flesh he will be likely to cut, and this is one of the most unpleasant defects in the horse, and one that it is very difficult to remedy. Press the hand closely and carefully around the pastern, for ringbone, or clingfasts, that are just commencing to form, will be detected more easily by the hand than the eye; 
this is the more important, as ringbone is one of the worst kinds of unsoundness, and the horse may not at all times, and in all instances, be sufficiently lame to enable the buyer to detect it.

The knees are often tou carelessly examined. It is not enough that there is no trembling of the joint, that it shuts back well, and is well shaped. If there are any bunches, hard or soft, or any scars in front, it is a pretty sure sign that the horse is a stumbler, and is unsafe. Just below the knees and upon the inside of the leg look for splints; if small and removed from the joint, they may in no way affect the usefulness of the animal, but they are unsightly and objectionable.

The feet require the closest scrutiny. Reject horses that have split or flat hoofs, as they will be fit only for slow work. Where the feet are high and narrow at the heels, it is a serious objection, as such feet are very liable to founder and other diseases. The legs and feet proving satisfactory thus far, take a look at the body. If the ribs are round, the back short, and his wind good, little more need be required.

To determine the soundness of the wind is sometimes difficult, especially if the horse is in high condition and has been dieted and medicated with the view of concealing some defect in it. The best way to determine this is to make him trot briskly about one hundred rods, and as soon as he has done this let him stand perfectly still and watch closely his breathing. If he breathes easily, and without any apparent effort, and especially if as soon as he stops, he draws one or two long breaths that fill the lungs to their utmost capacity without any appearance of distress, his wind 
may be pronounced good; but if there is the least evidence of painful respiration, or catching for breath, something is wrong, and the animal should be rejected. Heaves, or broken-wind, is a common disease at the East, but at the West it is comparatively very rare; hence the purchaser will be more on his guard to detect the disease in a horse raised at the East than in one raised at the West.

While the horse is moving, notice carefully his action, and to do this take such a position that he can move by you on level ground, and at a sufficient distance from you to give a good view of him. Notice particularly the action of the forelegs, see that the joint at the shoulder plays freely, that the feet are not raised too high, that he reaches out boldly in his step with his forelegs, and throws his weight freely upon them. If he does this, you may be pretty sure the feet are sound and good, and the shoulders unhurt. On the contrary, if the horse does not carry his feet well forward, but takes a short, mincing step, and puts down his feet cautiously, they are unsound; and if the legs seem stiff, and tied up at the shoulders, he is chestfoundered. These things should be carefully observed when the horse is first moved, for if he is but a little stiff in his shoulders, the stiffness generally disappears entirely after a little exercise.

After having carefully noticed these things, and also his general style and appearance, take such a position that you can watch the movement of his feet as he comes directly towards you and goes directly from you; see that he carries forward his feet in a straight line, and that he docs not travel too close or too wide, 
for if very close he will be apt to cut or interfere, and if too wide, his gait will be labored and awkward.

While the horse is moving, see if he hesitates to turn short and quick; if he does, and appears in the least stiff in the back, you may conclude that he has been strained there, and a horse that has been once severely strained in his back, rarely, if ever, fully recovers, and is unfit for any kind of business; but if the back is such as we have described, there will be little danger of this complaint.

These defects, at which we have glanced, by no means comprise all the diseases or defects of the horse, nor are the methods we have pointed out in all cases the only ones. We have aimed only to glance at the most serious and ordinary defects, and point out the simplest means of detecting them. Some quite common defects we have not noticed, as, for instance, ștring-halt. This is not considered unsoundness in ordinary circumstances, and where it is so bad as to become seriously objectionable, it cannot fail to be noticed by the most careless observer. To some, this kind of examination may seem tedious and laborious, and to the inexperienced horseman it may be so; but the horseman of taste, with a practiced eye, will determine the freedom of an animal from the objections we have referred to, in a small fraction of the time it has taken us to describe thom. We have said nothing upon those subjects that are merely matters of taste, as to enter into a discussion of them would occupy more space than we could devote to it.

One wishes a horse that shall have a bold, resolute style of action, and a high temper, that prompts him 
to keep up a constant and heavy pull upon the reins. Another wishes a horse of less spirit, with a quiet, pleasant temper, and a mouth that only feels the bit, that is never restless, never pulls, and so gentle that his wife and children can manage him. Yet he does not want a dull, stupid animal; on the contrary, one that is bright and lively, and that when gently urged will move off at a lively pace.

One wants a horse that is round and smooth, with soft hair, a beautiful color, and a proud, showy style, that will attract the admiration of his neighbors, but cares little about its speed upon the road, or its powers of endurance. While his next door neighbor cares far less for the showy style and the beautiful color, and values his horse solely on account of his useful qualities. In short, no rules can be laid down that will determine the excellence of the animal in these respects, as so much depends upon the precise service which is demanded of him, and the taste of the purchaser.

Although our people differ much in their opinion as to the color, style of movement, \&c., of their buggy horses, yet the anxiety to own a free, nimble driver, is nearly universal, and might almost be styled a national characteristic.

But the passion for horses is co-extensive with man's acquaintance with them, and is confined to no nation, no portion of the human family; indeed, there are comparatively few persons who take no interest in his history, no pleasure in training or using him.

Other animals may be as useful to man, but they do not so lay hold of human affections and sympathies. He is at once his companion and servant in lis long 
and weary journeys. With the same patience and unflinching courage, he carries his rider safely over the scorching sands of the desert, or treads with careful step the icy footpaths of the mountains. He waits with silent patience his master's pleasure, and moves only at his bidding. Heat and cold do not shake his courage, hunger and thirst do not drive him to rebellion. The soothing sound of his master's voice stills his restlessness when he wishes him to be quiet, and the cheering, encouraging tones of the same voice rouse him to the noblest efforts to do his will. 


\section{CHAPTER XV.}

THE following pedigrees and description of stallions, it is hardly necessary to say, comprise only a small portion of the total number that have been and are now bred from. But though thus incomplete, we believe the list comprises all the grandsons of the Justin Morgan, of any note. Of some of these we have been able to learn but little, though we have spared no pains to obtain as full and reliable a history and description of them as possible. The difficulty of collecting such facts, scattered over a wide extent of country, rarely published, and often unchronicled, save in the inemories of individuals, can never be fully understood, unless by those who have been engaged in some similar undertaking. Although we have made every exertion to render these pedigrees and descriptions reliable, and believe they will prove in the main corrcet, yet there are so many ways in which errors may creep in, and so many causes of confusion, that we dare not assert that they are perfeetly accurate.

The two most fruitful causes of error and confusion are, the use of some common name to designate different animals; and second, the frequent changes that have been made in the name of tho same animal. 


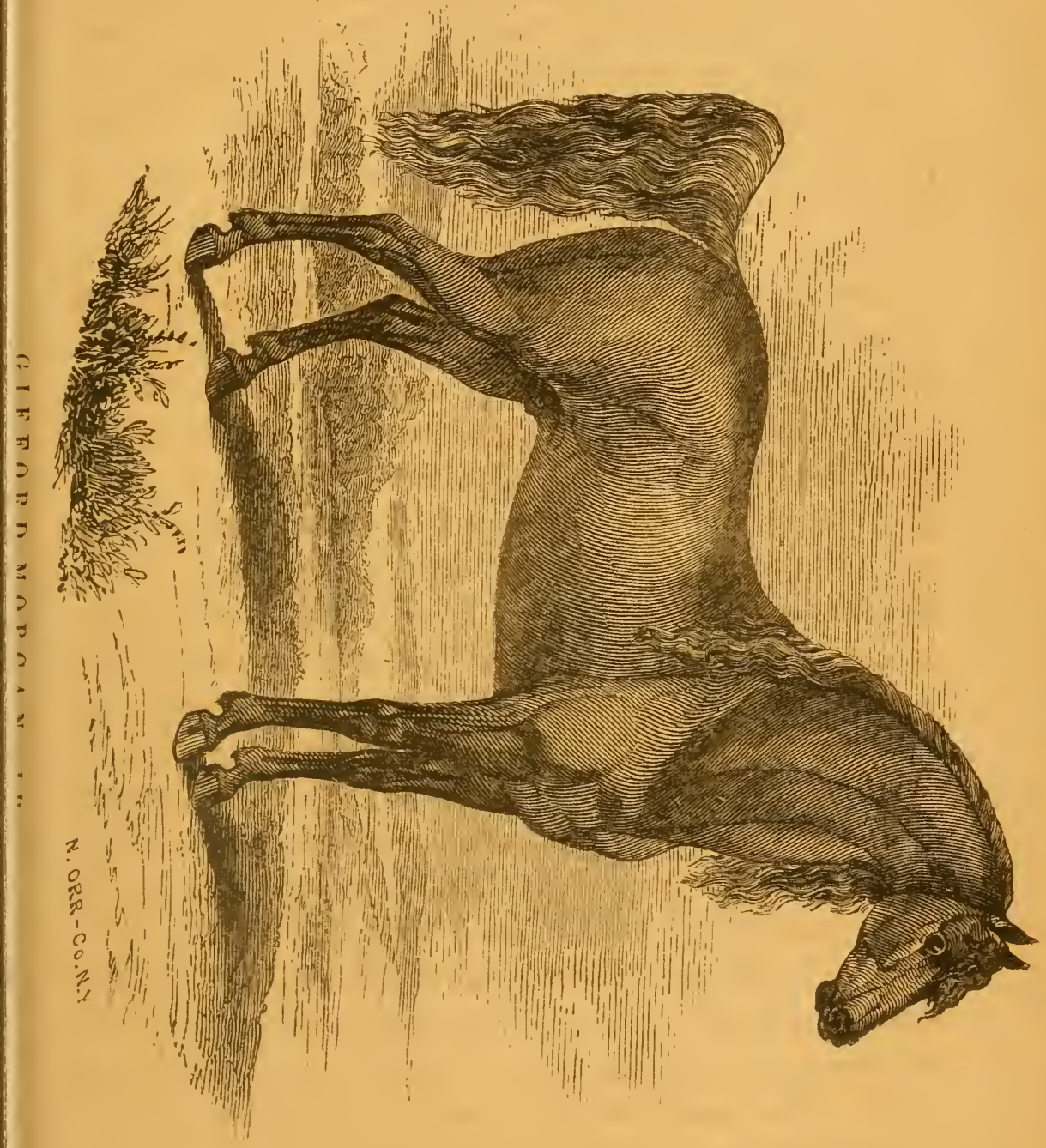



Thus there seems to be no end to the young Black Hawks, young Bulrushes, and other similar names. There seems to be a perfect mania for names that have been distinguished, as if it in some way enhanced the value of the animal. Again, some animals seem to have changed names as often as they changed owners, and even some that were always orved by one person are yet known by several different names. The Royal Morgan is known in Maine as Morgan Rattler; in some parts of Vermont, as the Crane horse; and in others, as the Steele horse; and by some as the Chamberlain colt; many persons who know him under one of these names never heard of either of the others.

Where we have described more than one animal of the same name, we have numbered them in the order in which they were foaled. Thus we have "Green Mountain," and "Green Mountain second." The former sired by "Sherman," and the latter by "Gifford." Many persons who know the latter, never heard of the former, and hence the necessity of distinguishing them as we have done.

The height and weight is not always the result of actual measurement; and consequently will not be in all cases perfectly correct. Where two estimates have been given us of the height or weight of the same animal, we have invariably adopted the lowest, deeming it better to err in this direction than to overstate the size. We shall feel obliged to any one who will inform us of any mistakes they may discover, and should a second edition be called for, we shall be most happy to correct them. 


\section{ASHUELOT MORGAN}

Was foaled in June, 1845, the property of Ezeliel Flint, of Winchester, N. H. Sired by Green Mountain 2d, g sire, Gifford, g g sire, Woodbury, $g \mathrm{~g} g$ sire, Justin Morgan. Dam formerly owned in Superior, C. E., and sired by Eagle. Ashuelot Morgan is a chestnut, with silver-colored mane and tail, both hind feet white up to the fetlock. He is 16 hands high, and weighs $1,315 \mathrm{lbs}$.

Although very large, he is compact, moves in good style, has excellent action for a horse of his size, and is a favorite parade horse. In 1855 he received the first premium of the New Hampshire State Agricultural Society. He is now owned by Uberto Bowen, Esq., of Richmond, N. H.

\section{ALLEN FORSE}

Was bred by Pliny Allen, of Lyme, N. H. Sired by Bulrush, g sire, Justin Morgan. Color, blood bay, 15 hands high, weight, 1,000 lbs. His reputation as a stock horse is good. He is now owned by Jonathan Currier, of Hanover, N. H.

\section{ALBAN HORSE}

Was foaled in September, 1839, the property of Colonel John Hackett, of Hancock, Vt. Sired by Hackett horse, g sire, Gifford, g g sire, Woodbury, g g g sire, Justin Morgan. Dam, a gray, sired by Bliss horse. His color is gray, spotted with chestnut and bay, is $14 \frac{1}{2}$ hands high, and weighs 950 lbs. He is a good horse; his stock come to maturity at an early age, and sell well. When four months old, Col. Hackett sold him to Wm. Alban, of Randolph, Vt. Mr. Alban kept him till he was seven years old, and sold him to Mr. Skinner, of Royalton, Vt. Mir. Slinner sold him to Lewis Gilman, of Bradford, Vt., and he to Leonard Kibbel, of the same place, who now ownes him.

\section{ANDREWS HORSE}

Was foaled in 1849, the property of William R. Andrews, of Derby, Vt. Sired by Royal Morgan, g sire, Sherman, $g \mathrm{~g}$ sire, Justin Morgan. Dan, a bay, 14 hands high, sired by Woodbury. Andrews horse is a dark bay, $14 \frac{1}{2}$ hands high, weighs $1,000 \mathrm{lbs}$, 
and is a good moving horse. He is still owned by Mr. Andrews, at Derby, Vt.

\section{AMERICAN EAGLE}

Was foaled May 16th, 1852, the property of Joshua Saunderson, of Petersham, Mass. Sired by Black Morgan, g sire, Morgan Empire, $g \mathrm{~g}$ sire, Green Mountain 2d, $g \mathrm{~g} g$ sire, Gifford, $g \mathrm{~g} g \mathrm{~g}$ sire, Woodbury, g g g g g sire, Justin Morgan. Jet black, $15 \frac{1}{2}$ hands high, weighs 1,070 lbs. Good style and action, spirited and graceful. Now owned by Joshua Saunderson, Pittsfield, Mass. Dam said to be an English mare, from a horse imported into Greenfield, Mass.

\section{ANDREW JACKSON}

Was foaled June 18th, 1852. Sired by Black Hawk, g sire, Sherman, g g sire, Justin Morgan. Dam, Lady Jenkins, who took the first premium at the State Fair, R. I., in 1855. Andrew Jackson is jet black, and weighs 1,050 lbs. He is a well-shaped and fine moring horse. He received a premium at the United States Fair in Boston, 1855, also at the Rhode Island State Fair, and Worcester Co. Fair, Mass. This horse is now owned by Harrison Bacon, of Barre, Mass.

\section{ADDISON}

Was foaled in 1851, the property of John Jackson, of Brandon, Vt. Sired by Black Hawk, of sire, Sherman, $g$ g sire, Justin Morgan. Dam, celebrated Hamilton mare, Ruby, purchased by Mr. Jackson when four years old for $\$ 750$.

Addison is 16 lands high. weighs 1,175 lbs., is jet black, with heavy mane and tail, high, bold style and good movement for a horse of his sizc. Now owned by Z. Nearing, of Orwell, Vt. He received the first premium in his class at the Fair of the Vermont Statc Agricultural Society in $185 \overline{5}$.

\section{ARABIAN MIORGAN}

Was foaled in 18522, the property of Epaphro Seymour, of Brattleborough. Vt. Sired by Billy Root, g sire, Sherman, g g sire, Justin Morgan. Dam, Old Jenny, sired by Sherman, g dam, by Arab, a thorough-bred Arabian horse, owned by Col. Jonas Blake, of Brat- 
tleborough, $\nabla$ t. This colt is chestnut, and exhibits in a high degree the valuable qualities of the Morgan and Arabian. He is now owned by Horatio Seymour, Jr., and Dr. M. M. Seymour in Buffalo, Erie County, N. Y.

\section{BULRUSH}

Was foaled in 1812 or 1813, the property of Moses Belknap, sired by Justin MIorgan. See Chapter VII.

\section{BULRUSH MORGAN}

Was forled in 1845, the property of Alvin Hovey, of Brookfield, Vt. Sired by Clarke horse, g sire, Bulrush, g g sire, Justin Morgan. Dam, sired by Morgan Eagle. Color dark bay, is 15 hands high, and weighs 1,060 lbs. He is a close-knit and well-formed horse, with good limbs and feet. His style of movement is good, and his temper excellent. At the Vermont State Fair in 1855, he received the second premium in his class.

\section{BLACK HAWK}

Was foaled in 1833, the property of Wingate Twombly, of Greenland (formerly of Durham), N. H. Sired by Sherman, g sire, Justin Morgan. His dam was raised in New Brunswick, and is described as a half-blood English mare, a very fine animal, black, and a fast trotter. When four years old, Black Hawk was purchased by Benj. Thurston, of Lowell, Mass., for a family horse, and kept for that purpose until 1844, when he was purchased by David Hill, Esq., of Bridport, Vermont, by whom he is now owned.

Celebrated horses, like great men, must have their enemies, and this horse has had his. A few years since a rumor was circulated that he was not sired by Sherman, but by a French horse called Paddy. The only foundation for such a report seems to have been the resemblance between the two horses in color, both being black. Mr. Hill might well have taken no notice of this rumor, as he had produced the affidavit of the owner of Sherman, in 1832, testifying that Sherman was coupled with the dam of Black Hawk that season, and that the following season he received payment for the same. The testimony of Mr. Bellows being unimpeached, the rumor might seem amply refuted and silenced, but Mr. Hill did not choose to rely solely on this affidavit. He obtained affidavits or 
letters from the breeder and others who had every opportunity of knowing the facts, fully and amply sustaining the afiflavit of Mr. Bellows. These papers were published, and have pretty effectually settled the question. The partics who first circulated the above rumor could have had little or no acquaintance with him or his stock, for with the exception of color, he bears a strong resemblance in most particulars to the family of which he is a member. In sizc, compactness, style of action, great muscular development, temperament, and endurance, he exhibits their distinguishing traits in a high degree. His stock, though generally larger, being from larger dams, exhibit much the same characteristies, and their color when not black, is almost without exception bay or chestnut, the latter color being quite common. Many of his colts have the same marks in the face and upon the feet that belong to Sherman and his dam. We never saw a gray, a white, or a cream-colored horse from him.

Black Hawk is a !ittle under fifteen hands high, and weighs about ten hundred pounds. His compact, symrnetrical, and muscular form, and nervous, elastic style of action, give unmistakable evidence of the speed and endurance he has shown upon the turf and road; and although now twenty-three years old, his eye has lost none of its brightness, his health is still excellent, and his movements still graceful and energetic. One of the chief excellencies of Black Hawk, and one which he possesses in a remarkahle degrec, is the uniformity with which he stamps upon his offispring his own distinguishing characteristics. For notice of his performances, sec Chapter X. Few colts were sired by him previous to 1844 , when he became the property of Darid Hill, and since that time he has been constantly kept at that gentleman's stabie, in Bridport, Vt.

\section{BAY MORGAN}

Was foaled in 1849, in East Berkshire, Vt. Sired by Nimrod. Dam, sired by Dubois IIorsc. His color is dark bay, without marks. He is owned by Joseph Smith, of Fast Berkshire.

\section{BAILEY HORSE}

Was foaled in 1835, the property of $\Lambda$ bner Bailey, of Newbury, $\nabla$ t. Sired by Woodbury, g sire, Justin Morgan. Dam, thickset 
Dutch mare. The Bailey horse was a chestnut, 15 hands high, weighed 1,100 lbs, and had one white hind foot.

\section{BARKER HORSE}

Was foaled in 1833, the property of Mr. Cobb, of Nelson, N. H. Sired by Woodbury, g sire, Justin Morgan. Dam, a bay, sired by Diomede, he by Imported Diomede. The Barker Horse was $15 \frac{1}{2}$ hands high, and weighed $1,100 \mathrm{lbs}$, color chestnut, with white stripe in the face like his sire, whom he closely resembled. His style and action were unsurpassed, and he was a very fine roadster. He was kept most of the time in Merrimac County, N. H., and vicinity. Mr. Barker kept him near home until 1853, after which Jesse Johnson and Brothers kept him at Bradford, Vt., and Concord, N. H., and vicinity, until he died, July, 1855, still the property of Mr. Barker.

\section{BARTHOLONEW HORSE}

Was foaled in 1826, the property of Moses Bartholomew, of Vershire, Vt., who raised and kept him till he died. Weight, 1,050 lbs., 15 hands high, color dapple bay. He had abundance of both speed and action, and was a fast trotter. Sired by Bulrush, $g$ sire, Justin Morgan.

\section{BONAPARTE}

Was foaled in 1836, the property of Johnson and Brothers, of Bradford, Tt. Sired by Bulrush, $g$ sire, Justin Morgan. Dam by Napoleon Bonaparte. Was $14 \frac{1}{2}$ hands high, and weighed 950 lbs., very compact, close built, a fast driver and strong goer. He resembled his sire very much. I. A. Weir, of Walpole, N. H., purchased him in 1845, and took him to that place.

\section{BLACK HAWK CIIIEF}

Was foaled in 1849, the property of D. Edgar Hill, of Bridport, Vt., by whom he is still owned. Sired by Black Hawk, g sire, Sherman, g g sire, Justin Morgan. Dam sired by Young Hamiltonian, formerly owned by Allen Smith, of Addison, Vt., Young Hamiltonian by Bishop's Hamiltonian, and he by Imported Messenger. Dam of Young Hamiltonian by Leonidas, $g$ dam by Bellfounder. 
Grand dam of Black Hawk Chief, sired by Imported Matchem, owned by J. S. Larrabee, of Shoreham, Vt.; height $15 \frac{1}{2}$ hands, weight 1,034, color raven black. This horse received the first premium at the New York State Fair in 1853, and also the first at the Addison County, Vt., Fair, in 1855. He is full brother to Sherman Black Hawk. He is spirited, but exceedingly gentle and tractable. Whole figure good. Head and neck beautiful. Style and action fine. Time, 2.48 .

\section{BLACK HAWK EOLIPSE}

Was foaled in 1853, the property of Jesse Johnson and Brothers, Bradford, Vt. Sired by Morgan Eciipse, g sire, Morgan Cæsar, g g sire, Woodbury, g g g sire, Justin Morgan. Dam, a Black Hawk. He is 14 hands high, weighs $975 \mathrm{lbs}$; ; color black, with a white stripe in the face. Sold and gone to South Carolina. An excellent moving horse, very clean, light head, general style and action good.

\section{BLACK HATK MORGAN}

Was foaled in 1852, the property of J. Johnson and Brothers, of Bradford, Vt. Sired by Morgan Eclipse, 'g sire, Morgan Cæsar, g g sire, Woodbury, g g॰g sire, Justin Morgan. Dam by Black Hawk. He is 15 hands high, weighs $950 \mathrm{lbs}$; ; color, chestnut.

\section{BURBANK HORSE SEE BARKER HOISE.}

\section{BLISS HORSE.}

Sired by Woodbury, g sire, Justin Morgan. Dam, sired by Justin Morgan, and known as the Charles Cutter mare, of Royalton, Vt.

\section{BUCHANAN HORSE}

Was foaled in 1836, the property of Jeremiah Boyington, of Newbury, Vt. Sired by Woodbury, g sire, Justin Morgan. Dam sired by Bulrush. Buchanan was bay color, weighed 1,000 lbs. When eight years old he was sold and taken to New Brunswick. 


\section{BOS'ION TIGER}

Was foaled in 1825 or 26 , the property of H. H. Kimball, of Whitefield, N. H. Sired by Cock of the Rock, g sire, Sherman, $g \mathrm{~g}$ sire, Justin Morgan. Dam, a gray, owned by H. H. Kimball. Tiger was 15 hands high, weighed 1,050 lbs. ; roan color, fine form and good action.

When five years old he was purchased by Joseph Sumner, Esq., of Charlestown, N. H. Mr. Sumner kept him several years, but becoming cross, he disposed of him, and he was put into a team in Boston or Mediford, where, in 1845, he was found and purchased by David Batchelder, of Haverhill, N. H., who kept him three years and sold him to Gen. Dolif, of Cast Wentworth, N. H., whose property he continued till his death in 1848 .

\section{BIRD HORSE}

Was foaled in 1851. Sired by the Bird horse, formerly owned by Joel Huntington and William Gay, and kept in Rochester and Hancock, Vt., g sire, Wolcott Morgan, g g sire, Gifford, g g g sire, Woodbury, g g g g sire, Justin Norgan. Dam by Gifford. Height,

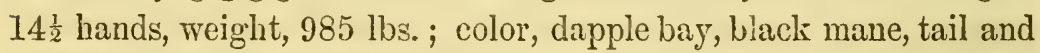
legs, with very fine action. Now owned by $\mathrm{A}$. Seymour, of West Randolph, Vt.

\section{BUSSORAH}

Was foaled in 1849, the property of Keyes Coburn, of Springport, Cayuga Co., N. Y. Sired by Gen. Gifford, g sire Gifford, g g sire, Woodbury, g g ge sire, Justin Morgan. Dam, Lady Howland, by imported Arabian Bussorah, g dam, by imported Messenger. $15 \frac{1}{2}$ hands high; weight, $1,075 \mathrm{lbs}$; color, bright bay. Now owned by B. J. Bidwell, of Tecumseh, Mich., and is a good horse.

\section{BACHELDER HORSE}

Was foaled the property of Joseph Bachelder, of Danville, Vt., sired by Sherman, g sire, Justin Morgan. Dam, a fast trotting gray mare, half French. This horse was of dapple gray color, and $14 \frac{1}{2}$ hands high. Though not as stylish as some of Sherman's colts, he was a spirited and fast traveller. Left some excellent stock. 


\section{BLANCHARD HORSE}

Was foaled the property of Joseph Tilton, of Danville, Vermont. His dam was a light bay, sired by Justin Morgan. Blanchard was sired by Sherman, g sire, Justin Korgan. Was of chestnut color, and weighed 1,000 lbs. He was a close-made, thick-set horse, but lis stock were not as noted for action as most of Sherman's colts. When young he was taken to New Hampshire, and afterwards to Maine. At an advanced age he was brought back to St. Johnsbury, Vt., where he diect.

\section{BROCK HORSE}

Was foaled in 1836, the property of Capt. William Brock, of Newbury, Vt. Sired by Parks horse, g sire, Green Mountain 1st, g g sire, Sherman, $g$ g $g$ sire, Justin Morgan. Dam by Shark. He was sold by Mr. Brock to Peter Johns, of Nashua, N. H. He weighed 200 , was blood bay color, had a fine figure and excellent, action, and was an uncommonly showy horse. Not fast.

\section{BLACK HAWK NAPOLEON}

Was foaled the 13th of MIay, 1852, the property of A. C. Palmer, of Charlotte, Vermonit. Sired by Black Hawk Prophet, g sire, Black Hawl, g g sire, Sherman, $g$ g g sire, Justin Morgan. Dam, of Messenger stock. 'This horse is 16 hands high, weighs about 1,100 lbs., and is of jet black color.

He received the highest premium in his class at the Vermont State Fair. 1855. A well-shaped, good-moving horse, Still owned by Mr. Palmer.

\section{BAXTER HORSE}

Was foaled in June, 1852, the property of Portus Baxter, of Derby, Vt. Sired by colt of Black Harw, g sire, Black Hawk, $\mathrm{g} g$ sire, Sherman, $g \mathrm{~g} g$ sire, Justin Morgan. Dam by Royal Morgan. He is $15 \frac{1}{2}$ hands high, weighs 1,050 lbs., with a very dark brown color, and white stripe in the face. Has a beautiful ear fine shoulders and withers, with good hips and back. His limbs are excellent. Promises to be fast. Now owned by Portus Baxter; of Strafford, $\Gamma$ t. 


\section{BLACK HAWK PRINCE}

Was foaled in 1851, the property of Mr. Mckinney, of Bridport, Vt. Sired by Black Hawk, go sire, Sherman, g g sire, Justin Morgan. Dam by Young Sir Walter, sire of Moscow, and he by Sir Walter. Prince is jet black, with small, white star in the face, 16 hands high, aud weighs $1,150 \mathrm{lbs}$.

McKinney sold him to Messrs. Gale \& Wright, in April, 1854. Col. Abram Foot, of Cornwall, Vt., afterwards purchased and now owns him. He is a very fine horse, with abundance of spirit, excellent action, and a hardy constitution.

\section{BROWN MORGAN}

Was foaled June 17, 1850. Sired by Morgan Sultan, g sire, Gifford, $\mathrm{g} g$ sire, Woodbury, g g g sire, Justin Morgan. Dam sired by Sherman King, g dam by Justin Morgan.

\section{BLACK MIORGAN}

Was foaled 28th July, 1845, the property of Sylvanus H. Gates, of Petersham, Mass. Sired by Gates Horse, g sire, Green Mountain 2d, g g sire, Gifford, g g g sire, Woodbury, g g g g sire, Justin Morgan. Dam raised in Middlebury, Vt. Sired by Green Monntain 2d. When three years old, Blaek Morgan was purchased by Francis Twichell, of Petersham, Mass., who kept him till he died, May, 1854. He received the fourth premium at the National Fair in Springfield, 1853.

\section{BAY STATE MORGAN 1sT}

Was foaled Iray 9, 1849, the property of Joshua Saunderson, of Pittsfield, Mass. Sired by Young Green Mountain, $g$ sire, Green Mountain $2 d, g$ g sire, Gifford, $g \mathrm{~g} g$ sire, Woodbury, g g g g sire, Justin Morgan. Color, bright bay, 15 hauds high ; weight, 1,060 lbs., and is a good horse. Now owned by Mr. Saundersou at Pittsfield.

\section{BAY STATE MOEGAN 2D}

Was foaled the property of S. B. Aiken, Hardwicke, Mass. Sired by Young Green Mountain, g sire, Green Mountain 2d, $g \mathrm{~g}$ sire, Gifford, $g$ g $g$ sire, Woodbury. g g g g sire, Justin Morgan. 
Dark bay, $16_{4}$ hands high, and weighs 1,150 lbs. He is now owned by Forrester B. Aiken, of Hardwicke, Mass. Good withers, good neck, good figure, and a good horse.

\section{BLACK LION}

Was foaled the property of Chester Pratt, Cornwall, Vt. Sired by Black Hawk, g sire, Shorman, g g sire, Justin Morgan. Dam, sired by Liberity.

\section{BILLY ROO', OR COMEL,}

Was foaled in 1829, the property of Hezekiah Morton, of St. Johnsbury, Vt. Sired by Sherman, g sire, Justin Morgan. Dam, a half French mare, sired by Justiu Morgan. A fine driver, and weighed 1,000 lbs.

Billy Root weighed 942 liss; color, dark chestnut, with a few white hairs in the forehead, and a little white on the off hind foot. The hair on his body was ratice long; but soft and silky, had but few long hairs on his legs and excellent feet. Eldad Root purchased him in 1832 or '33. Mr. Root liept him in the State of New York, we beliere at Genesee Flats; and he also kept him at Lyndon, Tt., several yearrs. When about ten years old he took him to Highgate, Vt., where he remained four years. Mir. Root sold him to Mr. Stevens, of St. Johnsbury, Vt. Mr. Stevens used him hard one year, and sold him to Mr. Filer, of Burize, Vt., who kept him a short time, and truded hin to Eleazer Smith, of Faverhill, N. H. Mr. Smith after a few months, traded him in the spring, back to Mr. Filer, who took him to Springfield, Mass., in the summer or fall of 1845, and disposed of him to a person who took him to Warehonse Point. 'The same autumn he was agrain traded to a man in Sharou, Coun. In the spring of 1847, (April 18th,) Messr's. Bemis \& Hoyt brought him back to Lyndon, where he was liept in 1817-'48-49, at I'loyt's stable. In 1850, he was kept at Highgate, and in 1851, at Lyndon, Vt. He died very suddenly April 25th, 1852. His death was supposed to be caused by the rupture of a blood-ressel. He was a horse of extraordinary life, energy and action. His stock are small, but have become widely and justly celebrated for spirit, action, endurance, and docility. 
BENTON HORSE.

SEE COOS MORGAX.

BARDWELI, HORSE.

SEE DEERFIELD MORGAN.

\section{BLACK JACK}

Was foaled Juno $\tilde{5}, 1849$, the property of Charles Linsley, of Middlebury, Vt. Sired by Hacket Horse, $g$ sire, Gifford, $g$ g sire Wootbury, g g g sire, Justin Morgan. Dam, Bay Flirt, bred near Inncaster, Ohio, and sired by Medley, le by Little Medley, and he by imported Medley, gg dam, by Shepard's Consul, and he by Bond's First Consul for further pedigree of Medley and Bond's First Consul, sae American Stnd Book. Black Jack is 15 hands high and weighs 1,070 lbs. ; color, black chestnut, without marks; is a compact, enduring horse, a good traveller, and is perfectly sound. He is now owned by G. L. Linsley, of Kankakce City, Illinois.

\section{BLAOK IAWK, JP., 1st,}

Was foaled in 1847, the property of Abraham F. Aburnethy, of Cornwall, Vt. Sired by Black Hawk, $g$ sire, Sherman, g g sire, Justin Morgan. Dam, Howard mare, sired by a colt of Hamiltonian. He is 15 hands high, and weighs $1,000 \mathrm{lbs}$. Mr. Aburnethy kept him tịll three years old, and sold him to Col. Abraham Foot, of Cornwall, Vt., who kept him till August 1852, when he sold him to Furnham \& Foot, of Lockport, N. Y., for $\$ 1,500$. He is still owned in Lockport by Col. E. II. Foot. With a very fine figure, le possesses an cxcellent temper, is a pleasant driver and goes in good style.

\section{BLACK HAWK, JR., 2D,}

Was foaled June 20, 1849, the property of James S. Phelps, of Middlebury, Vt. Sired by Black Hawk, g sire, Sherman, $\mathrm{g} g$ sire, Justin Miorgan. Dam, sired by a son of Giffords, g dam, by Young Hamiltonian. He is jet black color, 16 hands high, and weighs 1050 lbs. His limbs are light but sinewy, free from long hairs, and any sort of blemish. He has a bold, resolute style of action, and is now the property of Mr. Phelps, at Burlington, Iowa. 


\section{CLARKE HORSE}

Was foaled in 1840 or ' 41 , the property of Hall Cabot, of Chelsen, Vt. Sired by Bulrush, $g$ sire, Justin Morgan. Dam by Fortune, Fortune by Quicksilver, g dam by Justin Morgan. Height, 133 hands; weight, 875 lbs.; color, bright bay. One of the best acting sons of Bulrush. A fine, spirited animal. Went to Ohio.

\section{COCK OF THE ROCK}

Was foaled the property of Oliver Bowers of Danville, Vt. Sired by Sherman, g sire, Justin Morgan. Dam by Barnum's Cock of the Rock. Ine was a very light chestnut, with white face below the eyes, 15 hands high, and weighed 1,100 lbs. His cye, ear and head not so good, hut general form, Norgan. He attracted some notice in New Hampsinire and New York, in which States he was kept. Mr. Bellows, of Lancaster, N. H., purchased him of Mr. Bowers, and sold him to Horatio Sargeant, of Springfield, Mass., at a high price. Was a bold, proud-looking and active horse, and a five animal. Was a fast trotter, and left some good stock.

\section{COLBI HORSE}

Was foaled the property of Mr. Colby, of Warner, N.H. Sired by Barker horse, g sire, Woodbury; $\&$ g sire, Justin Morgan; is 15 hands high, weighs 1,050 , chestnut color, and a capital horse, with fune action and good figure.

\section{CHAPLES SUITH HORSE}

Was foaled the property of C. C. Smiti, of Corinth, Vt., and now owned by Leonard Arery, of same place. Sired by Young Bulrush, $g$ sire, Bulrush, $g \mathrm{~g}$ sire, Justin Morgan. Small size, weight 900, dark chestnut color, and good action.

CRANT HORSE, OR STEELE HORSE.

Sez Royal Morgan.

\section{CHILDS HORSE}

Was foaled the property of Col. Levi Childs, of Derby, Vt. Sired by Royal Morgan, g sire, Sherman, g g sire, Justin Morgan. Dam, a chestnut, 15 hands high, weighed 1,000, and sired by American 
Eagle. Childs horse is a dark bay, $14 \frac{1}{2}$ hands high, weighs about 975. Style and action very good. Now owned in Northampton, Mass.

\section{CHAMBERLAIN HORSE}

Was foaled in 1843, the property of Lathrop Chamberlain, of Brownington, Vt. Sired by Royal Morgan, g sire, Sherman, g $g$ sire, Justin Morgan. Dam, a bay, 15 hands high, weighed 950 lbs., and was sired by Olive Branch.

Chamberlain horse was a bay $14 \frac{1}{2}$ hands high, and weighed about 900 lbs. His movement was excellent, and he was full of life and spirit. He is now dear.

\section{CARPENTER'S GRAT}

Was foaled the property of Francis Drew, of Danville, Vt. Sired by Sherman, g sire, Justin Morgan. Dam, large gray, sired by Black Prince. He was $14 \frac{1}{2}$ hands high, weighed $1,050 \mathrm{lbs}$, and had plenty of bone, muscle, spirit, and action. He took his name from Danford Carpenter, of Danville, who owned him some time, and sold him to go to Massachusetts.

\section{CLIF"ION}

Was foaled in 1852, the property of Wm. Bellows, Lsq., of Walpole, N. H. Sired by Green Mountain $2 \mathrm{~d}$, g sire, Gifford, g g sire, Woodbury, $g \mathrm{~g}$ g. sive, Justin Morgan. Dam, a chestnut, sired by Gifford, $g$ dam by Sherman. Clifton is 144 hands high, and weighs 960 pounds. His color is a bright chestnut. $\Lambda$ therce months old Mr. Bellows sold him to Silas Fale, of South Royalston, Mass. At eighteen months old, Mr. Hale sold nim to S. H. Fdgerly, Esq., of Manchester, N. H., who slortiy after sold him to F. H. Lyford, Esq., whose property he still remains. Clifton is a bold-looking, active and muscular horse, and in many respects resembles hị celebrated sire.

\section{CLEMENTS HORSE}

Was foaled in 1826, the property of Mr. Clements, of Goshen, Vt. Sired by Woodbury, g sire, Justin Morgan. Dam was celebrated as a roadster, and descenderl from Imported Killdeer. 
Clements kept him till 1831, and then sold him to go to St. Lawrence County, New York. He was kept several years in Malone and vicinity, and was finally taken to Canada. His style and action were very fine.

\section{CHAMPLAIN}

Was foaled in 1851, the property of Robins Battell, of Norfolk, Conn. Sired by Black Hawk, g sire, Shcrman, $g \mathrm{~g}$ sire, Justin Morgan. Full brother to Vermonter. Champlain is now owned by Battell \& Phelps, in Fon Du Lac County, Wisconsin, and is a very fine horse.

\section{CHAMPION BLACK HAWK}

Was foaled in 1849, the property of C. W. Fletcher, of Orwell, Vt. Sired by Black Hawk, $g$ sire, Sherman, $g \mathrm{~g}$ sire, Justin Morgan. Dam, by Cock of the Rock, $g$ dam said to be out of a Bul. rush Morgan mare, by a Míessenger Horse. Champion Black Hawl is a dark red chestnut, $15 \frac{1}{2}$ hands high, and weighs $1,100 \mathrm{lbs}$, is compact and muscular, with beantiful car and head. He has taken the first prize at five State, and several County fairs. Spirit, style and action excellent. In the fall of 1855 he trotted two miles in 5 min. 45 sec. He is now owned by P. \& L. Melendy, Mount Healthy, Hamilton Co., Ohio. He was purchased by his present owners in August, 1855, of W. H. \& J. Ladd, Jeffersoll County, Ohio.

\section{COOS MORGAN}

Was foaled in 1848, the property of Charles Benton, of Newbury, Vt. Sired by Young Moscow. Dam was sired by Morgan Robbin, $g$ dam by Billy Root, $g$ g lam by Justin Morgan. He is a black chestuut, $15 \frac{1}{2}$ hands high, and weighs 1,045 lbs. $\mathrm{He}$ is very gentle, and perfectly kind in any service. Exceedingly wellbuilt, forward, and bold in style, though less nervous than some of his lin. He is a favorite stock lorse in the vicinity of Newbury. He has been exhibited for a premium but once, when he receired one, at the Termont State Fair, in 1853.

\section{CIARLEY}

Was foaled Mas 23, 1851, the property of Calvin Blodget, of Waterbury, Tt. Sired by Gifiord, g sire, Woodbury, g g sire, Jus- 
tin Morgan. Dam by Green Mountain 2d, g dam by Messenger. Charley is a dark, dapple bay, $14 \frac{1}{4}$ hands high, and weighs a little less than 1,000 lbs. He has no white hairs on him; mane and tail full and heavy, very compact, with good limbs and good action. He is an excellent roadster.

\section{CARLETON HORSE.}

\section{Sre Petrrs Morgax.}

\section{COMET.}

\section{SEg BILLy Root.}

\section{COME'T}

Was foaled in 1846, the property of Jonas Flint, of St. Johns, bury, Vt. Sired by Billy Root, g sire, Sherman, g* g sire, Justin Morgan. Dam, dark chestnut, linown as Crane mare. Sired by Royal Morgan, $g$ dam by Hublard horse, $g \mathrm{~g}$ dam, known as the Pierce mare. Comet is a chestnut, and weighs 1,050 lbs. He has taken several premiums. One at the National Fair at Boston, 1855, and one at the New Hampshire State Fair; also one in his own county. He is now the property of Mr. Woods, of Hancock, N. II., and is an excellent horse, with plenty of life, and a spirited, nervous style of action.

\section{CHALLENGI}

Was foaled Jun 3d, 1854, the property of Charles Linsley, Esq., of Middlebury, Vt. Sired by Black Hawk, g sire, Sherman, g g sire, Justin Morgan. Dan sired by White Mountain Morgan, g dam by Woodbury; weight, 882 lbs. ; $15 \frac{1}{4}$ hands high, black chestnut color, with stripe in the face, and three white feet. He is now owned by George L. Linsley, Kankalree, Ill.

\section{CLARKE HORSE.}

\section{SeE Whalebone.}

\section{DON JUAN}

Was foaled in 1852, the property of C. M. Fletcher, of Orwell, Vt. Sired by Champion Black Hawk, g sire, Black Hawk, g g sire, Sherman, g g g sire, Justin Morgan. Dam, Lady Fenry, sired by 
Barney Henry, g dam was of Messenger blood; 16 hands high, and weighs 1,210 lbs.; color, very dark dapple bay, heary, wary black mane and tail. When two years old he was entered for a purse, at Burlington, Vt., which he won, trotting mile heats in $3 \mathrm{~min} .10 \mathrm{sec}$. When three years old he trotted a half mile in 1 min. 22 sec. A fine horse, and still owned by Mr. Fletcher.

\section{DAVIS HORSF}

Was a Vermont horse, sired by Woodbury, g sire, Justin Morgan ; height, $14 \frac{1}{2}$ hands ; weight, $925 \mathrm{lbs}$; color, chestnut. Few white hairs in face, and one white hind-foot. Action and style good.

\section{DUBOIS HORSE}

Was foaled in 1818. Sired by Bulrush, $g$ sire, „ustin Morgan, color bay; moved in good style, and was fast; weight, 940 pounds. He was owned at one time in Burlington, rt.

\section{DAVIS HORSE}

Was foaled in 1852. Was sired by Bulrush, $g$ sire, Justin Morgan. He was $15 \frac{1}{2}$ hands high, and weighed 1,200 ; color, mahogany bay; action and speed not remarkable, but enduring and hardy

\section{DEERFIELD MORGAN}

Was bred in Shelburne, Mass., and was sired by Green Mountain $2 \mathrm{~d}, \mathrm{~g}$ sire, Gifford, $\mathrm{g} g$ sire, Wondbury, $g \mathrm{~g} g$ sire Justin Morgan. He is a good acting, sharp-going horse.

\section{EMPEROR}

Was foaled in 1837, the property of Rufus H. Hyde, of Chelsea, Vt., who kept him three or four years and sold him. Sired by Bulrush, g sire, Justin Morgan; weight, 1,000 lbs. ; bright bay ; good figure, but not remarliably good gait.

\section{ETHAN ALLEN.}

Was foaled in June, 1849, the property of J. WV. Holcomb, of 'Ticonderoga, N. I. Sired by Black Hawk, $g$ sire, Sherman, $g$ g sire, Justin Morgan. Dam, a medium size white mare oî Messenger 
blood; 15 hands high, and weighs about 1,000 lbs.; is a beautiful bay, with black mane and tail; is perfectly sound and kind, very tractable, and has an excellent temper and gait, either for the road or the turf. It is claimed by his friends that he is the fastest trotting stallion living, and the claim seems to be well founded. For further notice of his performances, sec Chapter $\mathbf{x}$. He is now owned by O. S. Roe \& Co., of Shoreham, Vt.

It has been reported that Ethan Allen was sired by Flying Morgan, an excellent horse, and one which he, in some respects, resembles. We have made careful inquiry into all the circumstances of the case, and we ean see no reasonable ground to doubt his having been sired by Black Hawh. Mr. Holcomb had bred two celebrated animals, Black Hawk Maid and Red Legs, from the dam of Ethan Allen by Black Fawk, and there ean be no question that the mare was coupled with Black Hawk in 1848. Flying Mrorgan was not kept for stock that year, but for a driving horse, and we believe was kept by chance one night at Ticonderoga. We believe that this, with the resemblance in eoler and shape of the head, furnish the ehief grounds for the report.

\section{ETHAN ALLEN 2D}

Was foaled in 1850 , the property of E. \& T. Sprague, of East Randolph, Vt. Sired by Putnam horse, g sire, Woodbury, $g$ g sire, Justin Morgan. Dam, a chestnut mare known as the Partridge mare. Sired by Woodbury. He is 15 hands high, and weighs 1,000 los. Color, ehestnut, with white stripe in his face. Great muscular power, with good style and action. Now owned by B.F. Parkhurst, of Randolph. His colts principally chestnat.

\section{ENFIELD HORSE}

Was foaled in 1824, in Enfield, Conn. Sired by Woodbury, g sire, Justin Morgan. Dam was raised in Connecticut, and was of the celebrated Janus stock.

Fnfeld remained in Connecticut until the winter of 1831, when his owner drove him to Addison County, Vt., with a load of fresh codfish. While on the road, he met with an accident that made hirn lame for some time, and he was sold to Joshua Scott, of Middle- 
bury. Mr. Seott kept him one year, and sold him to Austin Johnson. Mr. Johnson kept him two or three years, and sold him to go to the State of Maine. Since that time we have been unable to trace him.

He was a chestnut, $14_{\frac{1}{4}}^{3}$ hana's high, and weighed $975 \mathrm{lbs}$. He was an excellent horse ; a fast driver, and full of courage and life.

\section{ESTY HORSE}

Was sired by Black Hawk, g sire, Sherman, g g sire, Justin Morgan. Dam sired by Romeo, owned by E. Pike. Height, $15 \frac{1}{2}$ hands; weight, 1,000 lbs.; color, black roan. Good style and fast; but never was trained. Was burned in a stable when five years old. He was sire of the noted trotting mare, Lady Franklin.

\section{FENTON HORSE}

Was foaled in 1808, the property of Richard W. Fenton, of St. Johnsbury, Vt. Sired by Justin Morgan.

He was of a blood bay color; excellent in style and action, and a very fine horse. See Chap. VII.

\section{FLYING CLOUD IST}

Was foaled the property of Mr. Robinson, of New Bedford, Mass. Sired by Black Hawk, $g$ sire, Sherman, $g$ g sire, Justin Morgan. Dam by Andrew Jackson, of trotting celebrity; was a black mare, and weighod about 1,000 lbs.

Flying Cloud weighs about 1,000 lbs., and his color is black. $\mathrm{He}$ is now on Long Island.

\section{FLYING CLOUD 2D.}

This Flying Cloud is now in Ohio; was foaled the property of Gustarus Wiekes, of Tieonderoga, N.Y. Sired by Blaek Hawk, g sire Sherman, $g \circ$ sire, Justin Morgan. Dam sired by Magnum Bonum.

This horse is black, and weighs 1, 050 pounds.

FLYING MORGAN.

Was foaled in 1813, the property of R. MI. Adams, of Burlington, Vt. Sired by Hackett horse, $g$ sire, Gifford, $g$ g sire, Woodbury, $g$ g $g$ cire, Jus in Horgan. Dam sired by Woodbury. Flying Morgan is 14 
hands high, and weighs $900 \mathrm{lbs}$; color, blood bay, with white hind feet. When five years old he was sold to Dr. Wm. Russell, of Middleburg, Vt., but Mr. Adams repurchased him the following year, and has owned him ever since. He is a horse of a great deal of bottom and power ; trots perfectly square and fair ; goes smart; is perfectly sure for all he can do, and generally makes his best time the last heat. From heating and over-work, his eyes have been iniured, and he can see but little. For performances, see Chap. 10.

\section{FLYING MORGAN SPROU'}

Was foaled in 1852, the property of R. M. Adams, of Burlington, Vt. Sired by Flying Morgan, g sire, Hackett horse, g $g$ sire, Gifford, $g \mathrm{~g} g$ sire, Woodbury, og g g g sire, Justin Morgan, out of Messenger dam, of middling size. He is 15 hands high, and of a dark chestnut color. Took the second premium at the National Fair at Springfield, Mass., when he had nine competitors. Has an excellent temper, a free, open gait, and promises to be fast. Under Mr. Adams' care he has become one of the best trained and most thoroughly broken horses in the State, and we do not know of a horse equal to him in these respects. He is still owned by Mr. Adams, at Burlington, Vt.

\section{FOX}

Was foaled in 1813, the property of Col. Phinney, of Shrewsbury, Vt. Sired by Sherman, g sire, Justin Morgan. Dam unknown; 14 hands high ; weight, $975 \mathrm{lbs}$; color, dapple baj; a very few white hairs on his forehead, and very few long hairs on his legs ; mane and tail thick and bushy. In 1825 he was purchased by Mr. Oliver Brown, of Pittsford, Vt. Mr. Brown kept him about one year, and sold him to Harvey Yale, of Middlebury, Vt., for \$210. Mr. Yale, kept him five years; during this time he was kept at Huntington and Middalebury. In 1831, Mr. Yale sold him to Dr. Smith, of Huntington, for \$150. Dr. Smith kept him one year. From Huntington he went to St. Lawrence Co., N. Y.; from whence he was taken to Upper Canada, where he died. He was a horse of great spirit and action, and was a favorite parade horse.

\section{FAR A R H O R E}

SEE YOUNG RURBANK. 


\title{
FLINT HORSE
}

Was foaled in 1823, the property of Oliver Bowers, of Danville, Vt. Sired by Sherman, g sire, Justin Morgan. He was owned by Mrr. Bowers, Mr. Flint, Mr. Woods, and Mr. Bellows. He died in St. Johnsbury. He is said to have been a fine horse, but we have been able to learn no further particulars concerning him.

\section{FLYING MORGAN, OF PETERSHAM.}

\author{
SFE NORTH STAR.
}

\section{FALCON}

Was foaled May 31st, 1846, the property of Robbins Battell, of Norfolk, Conn. Sired by Black Hawk, g sire, Sherman, g g sire, Justin Morgan. Dam by the Yale horse; Yale horse by Barnum's Cock of the Rock ; g dam by Gifford. Falcon died at three years old.

\section{FALCON 2D}

Was foaled in 1849, the property of Robbins Battell, of Norfolk, Conn. Sired by Falcon, g sire, Black Hawk, g g sire, Sherman, $\mathrm{g} g \mathrm{~g}$ sire, Justin Morgan. Dam, a high-blooded Virginia mare

\section{FARMERS' BEAU'TY}

Was foaled in 1842, the property of Dr. Thatcher, of Wells River, Vt. Sired by Gifford, $g$ sire, Woodbury, g g sire, Justin Morgan. Dam, a bay, said to sired by Woodbury. Farmers' Beauty is about 15 hands high ; weighs $1,075 \mathrm{lbs}$, and is of dappled chestnut color. Stock excellent and uniform. He is a good traveller; has trotted in 2.53. He is now owned by D. M. Taggart, Goffstown, N. II.

\section{FOX MORGAN}

Was foaled in 1852, the property of Miller \& For, of New Ipswich, N. H. Sired by Comet, $g$ sire, Billy Root, $g$ g sire, Sherman, $g \mathrm{~g} g$ sire, Justin Morgan. The Fox Morgan is coal black, with a few gray hairs about his flanks; $14 \frac{1}{4}$ hands high, and weighs 950 lbs. $\Lambda$ ction spirited and stylish. 


\section{GOODALE HORSE}

Was foaled in 1836, the property of Luther Goodale, of Lyme, N.H. Sired by Woodbury, g sire, Justin Morgan. Height, 15혈 hands ; weight, 1,100 lbs. Heavy bone and muscle; courage and bottom excellent; action not the finest, but a good driver. He left some excellent stock. Mr. Goodale sold him in 1845 or ' 46 to B. F. Tillitson, of Orford, N.H., who sold him in 1849 or ' 50 , to a man in Danvere, Mass. Disposition not pleasant.

\section{G A T E HORSE. (SEE MORGAN EMPIRE.)}

\section{GREEN MOUNTAIN $1 \mathrm{ST}$}

Was foaled the property of Mr. Bachupp, of Rygate, Vt. Sired by Sherman, g sire, Justin Morgan. He was $15 \frac{1}{4}$ hands high; weighed 1,125 lbs., and was of a dusty brown color. He was taken to Greenfield, Mass., and sold for $\$ 1,000$.

\section{GREEN MOUNTAIN 2D}

Was foaled in 1834, the property of George Bundy. Sired by Gifford, $g$ sire, Woodbury, $g \mathrm{~g}$ sire, Justin Morgan. Dam sired by Woodbury, a dark bay mare of great beanty and action. This horse is $14_{2}^{1}$ hands high, and weighs 1,100 lbs. ; color, deep bay. Mr. Bundy sold him, when four months old, to Daniel Gay, of Stockbridge, Vt., who kept him till he was four years old, and sold him to Hiram Twitchell, of Bethel, Vt., and he sold him the same ycar to John Woodbury, of Bethel, Vt. Mr. Woodbury sold him to Silas Hale, of South Royalston, Mass., who kept him till 1855, shen he sold him to a stock company in Williamstown, $V$ t., where 1e is now owned. Mr. Hale took him West in 1853, and he received first premiums at the several State Fairs of Kentucky, Ohio, and Irichigan, and in 1854 he received the first premium at the Ver mont State Fair, at Brattleboro'. He has also taken several other preminms. He is a horse of great muscular development, and remarkably norvous, spirited action. 


\section{GOODALE HORSE}

Was foaled the property of John Demnick, of Lynn, N. H. Sired by Young Burbank, $g$ sire, Woodbury, $g \mathrm{~g}$ sire, Justin Morgan. $\mathrm{He}$ is of a bay color, and weighs 1,025 lbs. Left one stallion, the Bold Rusher, a fine horse, now dead.

\section{GREEN MOUNTAIN, JR.,}

Was foaled in July, 1851. Sired by Green Mountain 2d, g sire, Gifford, $g$ g sire, Woodbury, g g g sire, Justin Morgan. Dam known as the Harton Trotting Mare. In 1851 owned by George W. Bradstreet, of Royalton, $\nabla t$., and purchased of him by Reuben H. Lamb, of Boston. Sired by Gifiord.

Green MLountain, Jr., is 15 hands high, and weighs 1,035 lbs. His color is dark chestnut, or brown. He has the style and action of his sire and dam, and trots a mile in 3 minutes. Now owned by A. Lyman, of West Randolph, Vt. He is a very fast walker, and a very pleasant and stylish driver.

\section{GEN. GIFFORD $1_{\mathrm{ST}}$}

Was foaled in 1839, the property of Edward Eldridge, of Warren, Tt. Sired by Gifford, $g$ sire, Woodbury, $g$ g sire, Justin Morgan.

Gen. Gifford is a chestnut, $15 \frac{1}{2}$ hands high, weighs 1,040 lbs. He is a long-bodied, but compact horse, with good style and action; a pleasant temper, and abundance of life. Mr. Eldridge sold him to Calvin Blodget, of Waterbury, Vt. Mr. Blodget kept him about two years and sold him to George A. Mason, of Jorcian, N. Y.

\section{GEN. GIFFORD 2D}

Was foaled in 1849, in Walpole, N. H. Sired by Gifford, g sire, Woodbury, g g sire, Justin Morgan. Dam weighed 1,000 lbs. ; was foaled in 1831, in Woodstock, Vt. ; sired by Woodbury. Gen. $2 \mathrm{~d}$ is a bay, and weighs 1,000 lbs. A well-formed horse, of good action.

GENERAL COOK HORSE.

(SEE SHERMAN MORGAN.) 


\section{GENERAI TAYLOR}

Was foaled in Chelsea, in 1849, the property of Joseph Hatch. Sired by Black Prince. Dam, sired by Bulrush, g dam by Quicksilver, 15 hands high, blood-bay color, and weighs 1,000 lbs. Not remarkably bold and active, but symmetrical, hardy, and enduring, and an excellent horse. Received the first premium at the Orange County, Vt., Fair, in 1851, and also the first in the class of Bulrush Morgans, at the State Fair in 1854. Now owned by Elihu Norton, Chelsea, Vt.

\section{GLINES HORSE}

Was foaled in 1846, the property of James Glines, Haverhill, N. H. Sired by One Eye, g sire, Bulrush, g g sire, Justin Morgan. Dam, an English mare. His color is chestnut, and weighs about 1,100 lbs. He has gone West.

\section{GROSVNER COLT.}

(SEE PLATO.)

\section{GITFORD}

Was foaled June 23, 1824, the property of Riba Gifford, of Tunbridge, Vt. Sired by Woodbury, g sire, Justin Morgan. Dam foaled June 21sı, 1819, and sired by Henry Dundas, g dam by True Briton, g g dam by De Lancey's Imported Wild Air. Weighed 1,000 lbs., and was 141 hands high. Style and motion much admired, and was a favorite parade horse. Has left some excellent stock. March 17th, 1840, Mr. Gifiord sold him to Russel Topliff, of Barnard, Tt. In 1844, Mr. Topliff sold him to Lyman Stewart. Mr. Stewart sold him to go to the State of New York. In 1846 Mr. F. A. Weir, of Walpole, N. H., purchased him, and sold him to a stock company for $\$ 2,000$. He died Oct. 30th, 1850, at Walpole, N. H.

\section{GENERAL GIFFORD 3D}

Was foaled 20th Sept., 1851, the property of Mr. Woodard, of South Royalton, Vt. Sired by Gifiord, g sire, Woodbury, g g sire; 
Justin Morgan. Dam sired by General Gifford. Hc is 14 hands high, and weighs $945 \mathrm{lbs}$. Color chestnut, white face, and three white feet. Speed good for a colt that has not been trained.

\section{GIFFORD MORGAN, Jr.,}

Was foaled MIay 23d, 1850, the property of Elijal Judson, of Woodbury, Con. Sired by Gifford, $g$ sire, Woodbury, $g$ g sire, Justin Morgan. Dam, Ribbon Back, by Young Black Hawk; g dam was taken from Vermont to Con., in 1825, and was said to have been sired by the Justin Morgan. Gifford Morgan, Jr., is a jet black color, a little under 15 hands high, and weighs about 1,100 lbs. Is a free, pleasant traveller, and mores in good, bold style. Is very pleasant in his temper, perfectly tractable, and is a fine horse. $\mathrm{He}$ is now owned by Mr. H. B. Munson, and is kept at Keokuk, Lee County, Iowa.

\section{GREEN MOUNTAIN 3D}

Was foaled September 3], 18533, the property of H. B. Munson, of Seymour, Con. Sired by a son of Green Miountain 2d., g sire, Green Mountain 2d, g g sire, Gifford, g g g sire, Woodbury, g g g g sire, Justin Morgan. Dam sired by Moscow, g dam, by Woodbury. His color is dark chestnut, with silver colored mane and tail. Is 15 hands high, and is a promising coit.

\section{GRANITE STATE MIORGAN}

Was foaled June 21st, 1847, the property of Parker W. Home, of Farmington, N. H. Sired by Napoleon Morgan, g sire, Flint horse, $g$ g sire, Sherman, $g$ g g sire, Justin Morgan. Dan of Messenger descent. Granite State Morgan is a chestnutroan, with one white hind foot and a white stripe in the face, $15 \frac{3}{4}$ hands high, and weighs about $1,000 \mathrm{lbs}$. Is a good traveller, perfectly sound and kind, a pleasant, tractable temper, and can be driven by a child. He is now owned by C. C. Whitehouse, of Farmington, N. H.

\section{GENERAL GIFFORD, JR.,}

Wa foaled in 1851, the property of Charles W. Ingersoll, of Lodi, Beneca Co., N. Y, who at that time owned the General Gifford 1st. Sired by General Gifford 1st., g sire, Gifford, $\mathrm{g} g \mathrm{~g}$ sire, Woodbury, 
g $g$ g sire, Justin Morgan. Dam, the celebrated Mecicl: 's trotting mare. Her dam by Bucyrus, and he by American Eclipse. This Junior General is 16 hands high, and weighs 1,100 lbs. He received the first premium at New York State Fair, at Utica, Sept., 1852, first premium and medal at Michigan State Fair, holden at Detroit, 1854; also, the first prenium at Scneca County Fair, Oct. 1854. Action easy and graceful. He is a gocd horse. Nor owned by B. J. Bidwell, Tecumseh, Mich.

\section{GRANITE STATE}

Was foaled in 1851, the property of Josiah Cram, of Hancock, N. H. Sired by Comet, $g$ sire, Billy Root, $g \mathrm{~g}$ sire, Sherman, $\mathrm{g} g \mathrm{~g} g$ sire, Justin Morgan. Dam was sired by a horse called Tom Morgan. Tom Morgan was sired by a horse called Briton. The pedigree of the last two named we do not know. Granite State is light chestnut, and weighs 1,050 lbs. His style and action are good. When three years old, Mr. Cram refused $\$ 800$ for him, and still owns him.

\section{GOLDEN EAGLE}

Was foaled June 21st, 1851, the property of Jacob Blake, of Sutton, Vt. Sired by Morgan General, g sire, Billy Root, $g$ g sire, Sherman, $g \mathrm{~g} g$ sire, Justin Morgan. When four years old, he was pur chased by Wm. Hill, of Sutton, Vt., and taken to Maine. Dark chestnut color. Weight about 1,150 lbs. Moves in good style, has good figure, good constitution, and excellent limbs. Mr. Hill has lately taken him to Illinois.

\section{HALL HORSE}

Was foaled in Northumberland, Vt. Sired by Bulrush, $g$ sire, Justin Morgan. Weight, 1,100 lbs. Low, heavy built, and dark bay color. He was owned and kept several years by Mr. Hall, of Northumberland, Vt.

\section{IFUBBARD HORSE}

Was foaled in Straford, Vt., the property of Mr. Hubbard. Sired by Bailey horse, g sire, Woodbury, g g sire, Justin Morgan. Chestnut color. Weigin 1,000 ]bs. 


\section{HARLOW HORSE}

Was foaled the property of Mr. Harlow, of Hartland, Vt. Sired by Walker horse, $g$ sire, Woodbury, $g \mathrm{~g}$ sire, Justin Morgan. Weight 1,200 lbs. Dapple gray color. Action fine, and a sharp goer.

\section{HEBARD HORSE}

Was foaled in 1827, the property of Arial Hall, of North Roya!ton, Vt. Sired by Woodbury, g sire, Justin Morgan. Height $14 \frac{1}{2}$ hands. Weight, 1,050 lbs. Color bay, black mane and tail. Died in Williamstown, Vt., in 1854, the property of Mr. Hall. He was a very valuable horse, hardy, enduring, with fine style and action, and a good roadster. Left a great deal of excellent stock.

\section{HACKETT HORSE}

Was foaled in 1832, the property of Col. John Hackett, of Hancock, Vt. Sired by Gifford, g sire, Woodbury, $g \mathrm{~g}$ sire, Justin Morgan. Dam sired by Woodbury. Height, $14 \frac{2}{2}$ hands. Weight, 1,070 lbs. Color chestnut, thick set, compact horse, but style not so fine as some. Action good, and a horse of great endurance. He was a good roadster, and left excellent stock. Died Feb., 1850, the property of Mr. Hackett.

\section{HAMPDEN}

Was foaled in 1848, the property of Dr. J. Holland, of Westfield, Mass. Sired by Gifford, g sire, Woodbury, g g sire, Justin Morgan. Dam Polly, a sharp-going dark chestnut mare, of Messenger descent, formerly owned by Messrs. Morgan \& Stevens, of Palmer, Mass. Hampden is a dapple chestrut, a trifle over 15 hands high weighs 1,025 lbs., has a rery compact form, excellent constitution, pleasant disposition, and is a good driver. He is now owned by N. B. Washburn, Springfield, Mass.

\section{HUCKINS HORSE}

Was foaled in 18:14, the property of Henry Wooly, of Derby, Vt. Sired by Royal Morgan, $g$ sire, Sherman, $g$ g sire, Justin Morgan. Huckins horse is a bay, 15 hands high, and weighs a little over 1,000 lbs. He is full of courage and life. Is now owned in Topslan, it 


\section{HUBBARD HORSE 2D}

Was foaled in 1851, the property of Dr. Frederick Jones, of New Ipswich, N. H. Sired by Flint horse, g sire, Sherman, g g sire, Justin Morgan. Dam, a superior animal, noted for fleetness and endurance. This horse is now owned by George B. Hubbard, of Ashby, Mass., is 14 hands high, weighs $900 \mathrm{lbs}$. , is of a rich, darkbrown color, compact and finely-proportioned, of elegant action, and possesses the requisite points of a fleet horse.

\section{IVES HORSE}

Was foaled in 1839, the property of Julius Ives, of Stanstead, C. E. Sired by Royal Morgan, g sire, Sherman, g g sire, Justin Morgan. Dam, a gray about 15 hands high. Ives horse is a bay, about 15 hands higl, and weighs nearly $1,100 \mathrm{lbs}$. Style and action very good. He is now owned in Oswego, N. Y.

\section{JEMTE}

Was foaled in 1848, the property of Calvin Blodget, of Waterbury, Vt. Sired by Gifford, g sire, Woodbury, g g sire, Justin Morgan. Dam, Madam Lowe. Sired by Woodbury. Jemie is a chestnut, $14_{4}^{3}$ hands high, and weighs 950 lbs.; has no white hairs on him ; is close built ; stands high forward; has good style and action, and is a good driver. He is now owned by John G. Sherburn, and we think is in Richmond, McFenry Co., Illinois.

\section{JERRY}

Was foaled the 18th of June, 1849, the property of Calvin Blodget, of Waterbury, Vt. Sired by Gifford, g sire, Woodbury, $\mathrm{g} g$ sire, Justin Morgan. Dam by Hebard horse, g dam by Bulrush. Jerry is chestnut, with $\Omega$ little white on one hind font; $14_{4}^{3}$ hands high, and weighs 1,000 lbs. ; heavy mane and tail ; form close and compact; good action, and a free, pleasant driver.

KNIGHT'S HORSE.

(SEF VERMONT MORGAN CHAMPION.) 


\section{KARBY HORSE}

Was bred in Bath, N. H. Sired by Bailey horse, g sire, Woodbury, g g sire, Justin Morgan. Chestnut color, and weighs 1,12.5 lbs.

\section{KENT'S MORGAN}

Was foaled in 1844, the property of Adrial Kent, of Lancaster, N.H. Sired by Bailey horse, g sire, Woodbury, g g sire, Justin Morgan. Dam by Sherman This horse weighs 1,050 lbs.; is 15 hands high; a deep bay color ; star in the face and white hind feet; style and action good. Stock has proved excellent. Is now owned by A. J. Congdon, of Lancaster, N. H.

\section{KITE}

Was foaled in June, 1854, the property of S. Langdon, New Haven, Vt. Sired by Rising Sun, g sire, Black Hawk, g g sire, Sherman, $g \mathrm{~g}$ g sire, Justin Morgan; dam sired by Beaman horse, he by Black Hawk, g dam by Black Hawk. Kite is dark chestnut, $15+$ hands high, and weighs 880 lbs. He is now owned by Geo. L. Linsley, Kankakee City, Illinois.

\section{KEN'I' COIT'}

Was foaled in June, 1851, the property of G. W. Kent, of Newbury, Vt. Sired by Carleton horse, or Petus Morgan, g sire, Morgan Chief, $g \mathrm{~g}$ sire, Buìrush, $\mathrm{g} g \mathrm{~g}$ sire, Justin Morgan. Dam by Sherman. Kent Colt is.a blood bay, 141 hands high, weighs $975 \mathrm{lbs}$, with head, eye, and neck very fine; general figure and limbs good. Is still owned by Mr. Kent.

\section{LATHAM HORSE, OR MORGAN CHIEF,}

Was foaled at Wells River, Vt., the property of Peter Burbank, in 1832. Sired by Woodbury, g sire, Justin Morgan. Dam known as Empress, sired by Justin Morgan: $15 \frac{1}{4}$ hands high, weight, 1,000 lbs., and chestnut color.

When one year old, Mr. Burbank sold him to B. Latham, Esq, of Lyme, N. H., for \$150. In 1841, Mr. Lathan sold him to Col R. C. Sawyer, of Newbury, Vt., who kept him till May, 1847, when 
he sold him to Calvin Blodget, of Waterbury, Vt. In June, 1848, he was sold to Messrs. Wight \& Eldridge, of Warren, Vt., who in June, 1852, sold him to Messrs. Prescott \& Wilson, of Newbury, Vt. In the spring of 1854, he was taiken to New Jersey. He was not remarkable for style and action, but his stock proved good.

\section{LONE STAR}

Was foaled the 5th June, 1848, the property of Benj. B. Tuttle, of Newmarket, N. H. Sired by Estis horse, $g$ sire, Black Hawk, $g$

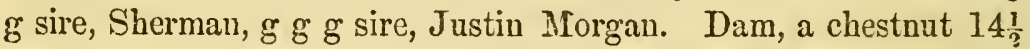
hands high, sired by Coek of the Rock. Lone Star is a blood bay, with small white star in forehead; $15 \frac{1}{2}$ hands high, and weighs 1,065 lbs., and is hall-brother to the well-known trotting mare, Lady Franklin. He has vever been trained, but he has a gait that indicates ability to trot. He is a fine horse, and is now owned by Sylvanus Tuttle, of Newmarket, N. H.

\section{LAWTON HORSE}

Was foaled in June, 1841, the property of Mr. Buckman, of Bethel, $V$ t., and is now owned by Miessrs. Woodward \& Flint, South Royalston, Vt. Sired by Green Mountain, 2d, $g$ sire, Gifford, $g \mathrm{~g}$ sire, Woodbury, g g g sire, Justin Morgan. Dam sired by Morgan Eagle. This horse is 15 hands high ; weighs 1,100 lbs., and his color is dapple bay. Style and action excellent, possessing both bottom and speed.

\section{LEMON FAIR}

Was foaled in 1851, the property of Robbins Battell of Norfolls, Conn. Sired by Black Hawk, g sire, Sherman, g g sire, Justin Morgan. Dam by Gen. Whitney's Arabian. He by Dey of Algiers, g dam by Duroc.

\section{MORGAN LION}

Was foaled May 31st, 1852, the property of J. C. Tibbits, Esq., of Sutton, $\nabla_{t}$. Sired by Morgan Gen., g sire, Billy Boot, g g sire, Sherman, $g$ g $g$ sire, Justin Morgan. Height, $15 \frac{1}{2}$ hands, grey 
color, and weight 1,150 lbs. ; very compact, close-built, high-headed, good acting horse.

\section{MORGAN TROTTER}

Was foaled in 1819 or '20, the property of Abel Whitney, near Chelsea, Vt. Sired by Bulrush, g sire, Justin Morgan. Dam, a large coarse common mare, light bay; weight, 1,150 lbs.

Morgan Trotter was 15 hands high, and weighed 1,000 lbs.; color, dark bay; remarkably strong, cordy limbs; a very hard driver and fast trotter. Charles Johnson bought him about 1823 or '24, and owned him foul' or five years, then sold him to go to Máne.

\section{O R G A N KI N G. \\ (SEE SIERMAN KING.) \\ MORGAN RAT}

Was foaled in 1822, the property of Judge Baldwin, of Strafford, Vt. Sired by Sherman, $g$ sire, Justin Morgan. When young he was taken to Maine, and kept in the vicinity of Norway, Stanwich and Gray. His stock was small, but invariably good roadsters, with fine action. He was brownish chestuut color; $13 \frac{1}{2}$ hands high, and weighed $850 \mathrm{lbs}$; with a symmetrical figure, he had a long body, which gave him his name. He was rery gentle and very spirited.

\section{MAY-FLY}

Was foaled in 1848. Sired by Farmer's Beauty, g sire, Gifford, g g sire, Woodbury, g g g sire, Justin Morgan. Dam sired by Wild Hawk of the Prairie, said to be a thorough-bred English horse, owned by Josiah Chase, Princeton, Mass. May-Fly weighs $900 \mathrm{lbs}$, and is of bay color. He is now owned by Chas. Perley, Boxford, Mass. Is a good-tempered, fine-acting horse.

M O O D Y HOR SE. (SEE ENFIELD HORSE.)

MOR G A N T I G E R . (SEE TIGER.) 


\section{MORGAN CAESAR}

Was foaled in 1828, the property of Simon Smith, of Hartland, Vt. Sired by Woodbury, g sire, Justin Morgan. Dam by Quick Silver, $g$ dam bred by John G. Bond, Keene, N. H., and by MIorton's I'raveller. (Not the Morton's Traveller of the Stud Book.) This horse was $15 \frac{1}{2}$ hands high, weight, $1,150 \mathrm{lbs}$. He was free from long hairs, had a fine head, ears and neck; mane and tail not as thick as is common. He was a fast driver, could go a mile in three minutes, and in March, 1844, was driven from Piermont to Wentworth, N. H., a distance of 12 miles, with two men in a sleigh, in 44 minutes. In 1833 or ' 34 he was taken to Maine by Spaulding Smith, of Wilton, Maine, and sold by him to Gen. John N. Eustis, of that State, for a parade horse. He remained there till 1842, and sired some excellent stock, of which was the celebrated trotting horse Mac, also the noted trotter, Pizarro, and a mare known as the Robert's Niare, very fast, and reputed to trot a mile in 2.35. The administratcrs of Gen Eustis' estate sold him to Manly Herriman, of Bradford, $\mathrm{Vt}$. He afterwards passed through several hands, until in March, 1816, he was purchased by Jesse Johnson $\&$ Brothers, who lept him till he died, June 1848. His stock sold high; many geldings brought from $\$ 300$ to $\$ 1,000$ each. This horse was known in Naine by the name of Morgan Post Boy.

\section{MATCHLESS}

Was foaled in 1851, the property of William MI. Parker, of Concord, N.H. Sired by Prince Albert, gr sire, Green Mountain 2d, $g$ $\mathrm{g}$ sire, Gifford, g g g sire, Woodbury, g g g g sire, Justin Morgan. Blood bay color, with black legs; $14 \frac{1}{2}$ hands high, and weighs $900 \mathrm{lbs}$. Fine style and action. He is a fine, symmetrical animal, with small, finely-shaped head and ear. Promises to be fast. Dam of Matchless was formerly owned by Hiram Woodruff. She was a celebrated roadster, and was half-sister to the great Trustee. She was black, about $14 \frac{1}{2}$ hands high.

\section{MODEL MORGAN}

Was foaled in 1850, the property of Dr. Lemuel Richmond, of Derby, Vt. Sired by Royal Morgan, g sire,Sherman, g g sire, Justin 
Morgan. Dam by White Mountain Morgan, g dam by Royal Morgan. Model is 14 hands high, and weighs $950 \mathrm{lbs}$; his color is dark mahogany bay, with very bushy, beantifully black mane and tail. He was exhibited at the Vermont State Fair in 1853, and the Committee in their Report to the Society say, "that he possesses as many, or more, of the traits of the old Sherman, than any other horse on the grounds."

\section{MORGAN STAP}

Was foaled in 1851, in the town of Shelburn, Mass. Sired by Deerfield Morgan, $\mathrm{g}$ sire, Green Mountain 2d, $\mathrm{g}$ g sire, Gifford, $\mathrm{g} g$ $g$ sire, Woodbury, $g \mathrm{~g} g \mathrm{~g}$ sire, Justin Morgan. Dam sired by Cock of the Rock, $g$ dam by Nagnum Bonum. Morgan Star is 15 hands high ; weighs 1,050 lbs. ; his color is a dark dapple bay. With a symmetrical tigure, he has fine style and action. Is now owned in Atwater, Ohio.

\section{MORGAN CHAMPION. (SEE VERMONT MORGAN CHAMPION.)}

\section{MORGAN NAPOLEON}

Was foaled in 1852, the property of A. C. Palmer, of Charlotte, Vt. Sired by Black Hawk Prophet, g sire, Black Hawk, g g sire, Sherman, $g \mathrm{~g} g$ sire, Justin Morgan. Napoleon is 16 hands high, and weighs 1,050 lbs.; his color is jet black, good mane and tail. He has a fine open gait, but has never been trained to trot. Received the first premium in the class three years old, at the last Vermont State Fair. He is a fine horse.

\section{MELVIN HORSE}

Was foaled in 1838, the property of Mr. Melvin, of Charlestown, Vt. Sired by Royal Morgan, $g$ sire, Sherman, $g$ g sire, Justin Morgau. Dam was a light gray, 15 hands high; weight, 900 lbs. Welvin horse is a light gray; $15 \frac{1}{2}$ hands high, and weighs over 1,100 liss. Style and action excellent. He is now owned in Kalamazoo, Michigan.

\section{MORGAN COMET.}

(SEE IVES IIORSE.) 


\title{
MORGAN C II I E .
}

\author{
(SEE LATIIAN HORSE)

\section{MERRIMAN HORSE}

Was foaled in 1851, the property of L. Merriman, of Stanstead, C. $\mathrm{E}$. Sired by Royal Morgan, $\mathrm{g}$ sire, Sherman, $\mathrm{g} g$ sire, Justin Morgan. Dam, a chestnut, weighs about $900 \mathrm{lbs}$, sired by Sir Richard. Merriman horse is a bay, 14 hands high, weighs 975 lbs., gnod style, and a good traveller. He is now owned by Robert Trumbull, of Belle Centre, Ohio.

\section{MORGAN FIGURE}

Was foaled in 1850, the property of Solomon Steele, of Beebe Plains, C. E. Sired by Royal Morgan, $g$ sire, Sherman, $g$ g sire, Justin Morgan. Dam, a black, sired by Piermont Morgan, $\mathrm{g}$ dam sired by Hawkins' horse. Morgan Figure is a jet black, 14 hands high; weighs 950 lbs. He is an excellent horse, compact, with plenty of bone, clean, sinewy legs, with fine style and pleasant temper; he is a good roadster. He is still the property of Mr. Steele.

\section{MORGAN POST BOY. \\ (SEE MORGAN CRSAR.) \\ MORGAN DEFIANCE. \\ (SER BROCK HORSE.)}

\section{MORGAN DRAGON}

Was foaled in July, 1853, the property of Gen. Silas M. Burroughs, Medina, N. Y. Sired by young Black Hawk, $g$ sire, Black Hawk, g $g$ sire, Sherman, $g$ g $g$ sire, Justin Morgan. Dam by Imported Emigrant.

\section{MORGAN DEFIANCE}

Was foaled June 14th, 1844, the property of Harvey Nobles, of Hartford, Vt. Sired by the Dennison horse or Gold Finder. Dam, celebrated stock and road mare, Old Lady Morgan; sired by Sherman. Morgan Defiance is a jet black, 15 hands high, and weighs 
1,030 lbs., compact, well-formed figure, and high carriage. $\mathrm{He}$ is now owned by an Association in Northfeld, Vt.

\section{MORGAN EAGLE}

Was foaled in 1827, the property of Daniel Morgan, of Royalton, $\nabla$ t. Sired by Woodbury, g sire, Justin Morgan. Dam, blood bay, of 1,000 pounds weight; an excellent roadster, but blood unknown.

Eagle was $14 \frac{1}{2}$ hands high, and weighed about 1,100 lbs.; dapple bay, high style, fine action, and free, pleasant driver. Morgan sold him to Mr. Sprague, of Randolph, Vt. In $1832 \mathrm{Mr}$. Sprague sold him to Philip Farnhan, of Turnbridge, Vt. Mr. Farnham kept him till 1839, and sold him to $\Lambda$. M. Foster, of Barre, Vt., and he kept him till he died, in 1810. The stock of Morgan Eagle were compact, rugged horses, and fine drivers. Morgan Eagle was the sire of Lady Sutton.

\section{MORGAN EMPEROR}

Was foaled the property of Mr. Hough, of Lebanon, N.H. Sired by Bulrush, g sire, Justin Morgan. Dam sired by Imported Prince William, formerly kept at Hartford, Conn. Emperor was $15 \frac{1}{2}$ hanrls high, and weighed 1,025 lbs., color blood bay. Jesse Johnson and Brothers kept him one year in Burlington, Vt., in 1835, and while there he trotted a mi?e in 2 min. 55 sec. Afterwards they kept him in Bradford two zears, when he was sold to Messrs. Hamet and Butler, of Burlington, Yt. In 1837 he went to Chicago. Sired Chicago Jack, geluing, and North Star, who took the second premium at the National Fair in Springfield, Mass.; also the Tillitson horse, who trotted a mile in 2 min. 40 see., on Cambridge Park Course, in Soptember, 1843. From Chicago he returned to Burlington, and went from there to Petersham, Mass., where he died in the autumn of 1853. He was close and compact, with good figure ; had a very heavy mane and tail, went with mouth wide open, and more from the whip than from spirit.

\section{MORGAN ECLIPSE}

Was foaled in 1848, the property of J. \& R. C. Johnson, of Bradford, $\mathrm{T}$ t. Sired by Morgan Cæsar, $\mathrm{g}$ sire, Woodbury, g g sire, Justin 
Morgan. Eclipse was own brother to Morgan Traveller, 15 hands high, and weighed 991 lbs.; color, beautiful chestnut. Was sold in 1834 to an Agricultural Society in New-Brunswick, for over $\$ 2,000$. His stock have taken several premiums at State Fairs in Vermont. At the Fair at Brattleboro three of his colts took premiums, besides two mares with foals by their side from him. He was a very fine horse. Pedigree of dam, see Traveller.

\section{MORGAN EMPIRE}

Was foaled in 1845, the property of Charles Gates, of Petersham, Mass. Sired by Green Mountain 2d, g sire, Gifford, g g sire,Woodbury. $g \mathrm{~g} g$ sire, Justin Morgan. Morgan Empire is $15 \frac{1}{2}$ hands high, and weighs a little under 1,100 lbs. ; is a horse of good action, and very muscular. He is now owned by G. W. Chamberlain, of Waltham, Mass. : is a good horse, and has a good reputation for stock.

\section{MORGAN FMPEROR 2D}

Was foaled in June, 1849, the property of Josiah White, of Petersham, Mass. Sired by Morgan Emperor, g sire, Bulrush, g g sire, Justin Morgan. Dam said to be by Sherman. Morgan Emperor is a deep bay, 15 hands high, and weighs 1,075 lbs. He is a strong, well-formed, fine moving horse. In 1855 he took two premiums, one at United States Fair in Boston, and one at Worcester, Mass. He is now owned by Harrison Bacon, of Barre, Mass.

\section{MORGAN HUNTER}

Was foaled in 1814, the property of Mr. Exwell, of Springfield, Vt. Sired by Gifiord, $g$ sire, Woodbury, g g sire, Justin Morgan. Dam sired by Gifford. Hunter is $14_{4}^{3}$ hands high, and of chestnut color. Messirs. Achley \& Gilbert, of East Hamilton, Madison Co., N. Y., purchescl him in May, 1849, but he is now owned by Messrs. Farriss and Cook, of Charlottesville, Va. Is a horse of beautiful figure and fine action.

\section{MORGAN CHIEF}

Was foaled June 18th, 1847. Sired by Gifford, g sire, Woodbury, $\mathrm{g} g$ sire, Justin Morgan. Dam sired by Green Mountain 2d, g dam 
by Messenger. Height $14 \frac{3}{4}$ hands, weight 960 lbs., color light. brown, with small star in his forehead. Owned by H. R. Ackley, of East Hamilton, Madison Co., N. Y. Morgan Chief lost one eye by an accident.

\section{MORGAN ROBBIN}

Was foaled in 1827, the property of Mrr. Chamberlain, of Danville, Vt. Sired by Sherman, g sire, Justin Morgan. Dam sired by Justin Morgan. This horse was $14 \frac{3}{4}$ hands high, weighed $1,000 \mathrm{lbs}$, color bright bay, black mane and tail, with ail his legs white half up to his knees. Remarkably fine style, great deal of bone and muscle, perfectly gentle, good roadster, and fine horse. Mr. Allen lept him till 1853, when he sold him to I. D. Ide, of Ljndon, Vt., who kept him till he died, the next autumn. He was kept at Keene, Lynn, and Walpole, N. H., and at St. Johnsbury, Vt. He was sold when young, and owned by Mather Alien, of Guildhall, Vt., for many years.

\section{MORGAN RATTLER.}

\section{(SEE ROYAL MORGAN.) \\ MORGAN RECRUIT}

Was foaled in July, 1851, the property of Ebenezer Bridges, of Pomfret, Vt. Sired by Green Mountain 2d, g sire, Gifford, $g \mathrm{~g}$ sire, Woodbury, g' g g sire, Justin Morgan, g dam by Woodbury. Recruit is dark chestnut, 14 hands high, weighs $1,020 \mathrm{lbs}$, thick set, with good limbs, short head, open nostrils, face dishing, wide between eyes, and very heavy mane and tail. Now owned by E. Bridges, of Pomfret, Vt.

\section{MORGAN TIGER 1sT}

Was foaled in 1827, in Whiteficld, N. H. Sired by Cock of the Rock, $g$ sire, Sherman, $g \mathrm{~g}$ sire, Justin Morgan. Dam sired by the noted Bellifounder. Tiger was a gray roan, 154 hands high, and weighed 1,025 lbs. He was a very hardy, enduring horse, full of courage, and good action. At four years old he was sold to Judge Sumner, of Charlestown, N. H. Judge Sumner kept him a number of years, and then sold him to some one in Boston for a parado 
horse. He remained in Boston several years, until, his stock proving excellent, he was hunted up and brought back to Corinth, $V t$., by Daniel Batchelder, of that place. He remained in Orange Co., Vt., and Grafton Co., N. H., until his death in 1850. He left good stock.

\section{MORGAN BUCEPHALUS}

Was foaled in 1853, the property of Geo. W. Cook, of Fairlee, Vt. Sired by Morgan Eclipse, $g$ sire, Morgan Cæsar, g $g$ sire, Woodbury, g g g sire, Justin Morgan. Dam by Woodbury. Color chestnut, 14 hands high, weighs 900 lbs., has a white stripe on the nose.

\section{MORGAN GENERAI,}

Was foaled in 1845, the property of Lowell Spencer, of Concord, Vt. Sired by Billy Boot, $g$ sire, Sherman, $g$ g sire, Justin Morgan. Dam, a very large mare, fast for her size, sired by Black Prince, dam still living, 26 years old. General weighs $1,200 \mathrm{lbs}$., is $15 \frac{1}{2}$ hands high, and chestnut color. He is a very bold looking horse, fine style, and good action for a horse of his size; ver'y compact, limbs excellent, but have some long hair on them. Is a good horse. He is now owned by Wm. Hill, Oregon City, Ill.

\section{MORGAN RATTLER}

Was foaled Jume 1st, 1850, the property of Jonathan Brewster, of Worthington, Mass. Sired by Green Mountain 2d, g sire, Gifford, $\mathrm{g} g$ sire, Woodbury, $g \mathrm{~g} g$ sire, Justin Morgan. Dam, a fast-trotting dark bay, sired by Rattler. This horse is a dark bay, $15 \frac{1}{4}$ hands high, and is now owned by A. W. Kellogg, of Chicago, Inlinois. At the Housatonic Fair, held at Great Barrington, Mass., in 1854, and at Rutland, Vt., County Fair, the same year, he received the first premium.

\section{IIAJOR}

Was foaled in 1852, the property of Robbins Battell, of Norfolk, Conn. Sired by Raven, g sire, Black Hawk, g g sire, Sherman, g g g sire, Justin Morgan. Dam, a Narragansett pacer. We have no further description of this horse, but we believe he is a good one. 


\section{MORGAN SUL'TAN}

Was foaled 22d May, 1846. Sired by Gifford, g sire, Woodbury, g $g$ sire, Justin Morgan. Dam, sired by Gifford. Sultan was a dapple chestnut.

\section{MORGAN TRUSTEE}

Was foaled May 16th, 1818. Sired by Gifford, g sire, Woodbury, g g sire, Justin Morgan. Dam by Bulrush, g dam by Morgan Fortune, $g \mathrm{~g}$ dam by Justin Morgan. Trustee was a dark bay, black mane, legs and tail, and a fine horse.

\section{MAJOR GIFFORD}

Was foaled in 1843, the property of Mir. Eilis, of Springfield, Vt. Sired by Gen. Gifford, $g$ sire, Gifford, g $g$ sire, Woodbury, $g$ g $g$ sire, Justin Morgan. Dam by Spectator, and he by one of Messenger's sons.

At three years old $\mathrm{M}$-. Ellis sold him to Calvin Blodget, of Wat. erbury, Vt. In $1 \subseteq 47$, ' 48 , and ' 49 , he was kept at Chelsea, Vt., and in the fall of 1849 , at the N'er Tork State Fair at Syracuse, Mr. Blodget sold a half interest in him to A. Mason, of Jordan, New York, and in 1856 sold the remaining interest to the same gentleman.

\section{MOUNTAIN EAGLE}

Was foaled the property of Mr. Buckminster, of Danville, Vt. Sired by Sherman, $g^{*}$ sire, Justin MIorgan. Dam, Lady Empress, an English mare. Eagle is a dark chestnut, $15 \frac{1}{2}$ hands high, and weighs 1,050 lbs. Amos Kendall took him to Jefferson County, New York. When we last heard from him he was owned by Martin Hungerford, Watertown, Jefierson Co., New York. Tery showy, and active horse.

\section{MORGAN CHIEFTAIN}

Was foaled in September, 1853, the property of W. P. Balch, of Boston, Mass. Sircd by Comet, g sire, Billy Root, g g sire, Sherman, $g$ g g sire, Justin Morgan. Dam raised in Bradford; sired by Woodbury; could trot a mile in three minutes, and was a fast 
traveller. Chieftain is a dark dapple chestnut. He is a stout, thick-built horse, and when 26 months old weighed $930 \mathrm{lbs} . \mathrm{He}$ carries a high head, and has a small ear. He is a promising horse. He is now owned by Mr. Balch, and is kept in Hancock, N. H., by Hiram Fuller.

\section{MORGAN BLACK HAWK}

Was foaled in 1849, the property of G. Pamsdale, New Ipswich, N. H. Sired by Anglo Saxon, g sire, Black Hawk, $g$ g sire, Sherman, $g \mathrm{~g} g$ sire, Justin Norgan. Dam, a noted mare, of Sherman Norgan blood.

Morgan Hlack Hawk is $15 \frac{1}{2}$ hands high ; weighs 1,030 lbs. His color is dark, dappled bay. A fine, compact-looking horse, and a good travelier.

\section{MESSER HORSE. \\ (SEE SIIEMMAN MORGAN.) \\ MORGAN WRAVELER}

Was foaled in 1847 , the property of J. \& R. C. Johnson, of Bradford, Vt. Sired by Morgan Cæsar, g sire, Woodbury, g g sire, Justin Morgan. Dam, known as Lady Clifton, sired by America Eclipse. Morgan Traveller is a beantiful dark ehestnut, 15 hands high, weighs 1,000 lbs., and is a horse of very fine form and excellent action.

\section{MORGAN 'TRAVELER 2D}

Was foaled in St. Lawrence Co., N. Y., in 1850. Sired by Mountain Fagle, $g$ sire, Sherman, $g \mathrm{~g}$ sire, Justin Morgan. He is dark chestnut, 16 hands high, and well proportioned. Took the first premium at St. Lawrence Co., N. X., Fair, in 1852.

MYRICK HORSE.

(SEE SHERMAN BLACK HAWK.)

MORGAN TALLY HO.

(SEE WALKER HORSE.) 


\section{MORGAN CONET}

Was foaled in 1849, in St. Johnsbury, Vt. Sired by Billy Root, $g$ sire, Sherman, $g \mathrm{~g}$ sire, Justin Morgan. Dam, a half-blood English mare. He is well-proportioned, a good traveller, moves in beautiful style, thoroughly broken, can be driven by anybody. His stock is good, and he is a fine horse. He is chestnut, ahout 15 hands high, and weighs about 1,000 lbs. He is now owned by A. H. Wilcox, St. Jolnsbury, Vt.

\section{MORRILL HORSE}

Was sired by Jenuison horse, g sire, Young Bulrush, g g sire, Bulrush, $g \mathrm{~g} g$ sire, Justin Mnrgan. Dam sired by Farrington horse, he by Vance horse, and Vance horse by Imported Messenger. Morrill horse is thirteen years old, a jet black color, and weighs 1,225 lbs. He is a powerful and fast-trotting horse.

\section{IIORGAN TIGER 2D}

Was foaled in 1827, the property of Major Ford, of Braintree, Vt. Sired by Sherman, g sire, Justiu Morgan. About 1831 he was sent to Chariestown, Mass., and was kept at Col. Jaques, where he remained ten years. In 1843 he was bought by $\mathrm{Mr}$. Howe, of Bridport, Vt. ; and brought into Bridport, Addison county, where he was kept two scasons. Ho was a superior horse; and when four years old, was valued at $\$ 1,000$. His color was dark bay, with two or three white feet, star in the forehead, and heary curly black mane and tail; was $14_{4}^{3}$ hands high; weight, 975 lbs. His action was good; he was not fast, but hardy and enduring; he was old, when we first saw him, and was foundered.

\section{MORGAN FUSION}

Was foaled Nay 7 th, 18.56, the property of H. B. Munson, of Seymour, Conn. Sired by Raven, g sire, Black Hank, g g sire, Sherman, g g g sire, Justin Morgan. Dam, Dolly IIale, was sired by Green Mountain 2d, $g$ dam by Young American Eclipse, g $g$ dam, Imported Silk Stockings. Dolly Hale was half brother to the celebrated trotting horse Ripton. 


\section{MOUNTAINEER}

Was foaled July 15th, 1854, the property of Ira Gifford, of New Haveu, $V^{\imath}$. Sired by Rising. Sun, $g$ sire, Black Hawk, g $g$ sire, Sherman, $g \mathrm{~g} g$ sire, Justin Morgan. Dam sired by Wheeler Lorse, $g$ dam by Hebard horse.

Mountaineer is dapple chestnut, without marks. Above medium size, with excellent limbs, good style of action, and is a promising colt.

\section{NEITTON HORSE}

Was foaled in Haverhill, N. H. Sired by Bailey horse, g sire, Woodbury, g g sire, Justin Morgan. Weight, 1,100 lbs. Color, chestnut.

\section{NORTH HORSE. \\ (SEE SHERMAN BLACK HAWK.)}

\section{NEWEL'S GRAY}

Was foaled the property of Mr. Stiles, of Waterbury, Vt. Sired by Sherman, $g$ sire, Justin Morgan. Dam of brown color, large and heary. Sired by Vance horse (Vance horse was gray); he by old Phœnix. Newel's Gray was gray; $15 \frac{1}{2}$ Lands high; fine figure with a great deal of fire and spirit, but wanted bone. He took his name from T. Newel, who owned him for a long time. $\mathrm{He}$ was burned. in the stable of Mr. Sparhawk, of Walpole, N. H., in 1838 or '39. Mrr. Sparhawk purchased him of John Bellows.

\section{NORTH STAR}

Was foaled the property of David Lincoln, of Greenwich, Mass. Sired by Morgan Emperor, g sire, Bulrush, $g$ g sire, Justin Morgan. Dam, a bay. He took the second premium at the National Fair at Springfield, Mass., 1854. He is a bright bay ; weighs 1,060lbs. ; black and curly mane and tail. He is a very symmetrical, well-shaped horse, with fine bold style and excellent action; and is now owned by Heury Olmstead, Last Hartford, Conn.

NEARING HORSE.

(SEE ADDISON.) 


\section{NILES HORSE}

Was foaled in 1846, the property of Daniel Niles, of Canada East. Sired by Royal Morgan, g. sire, Sherman, $g \mathrm{~g}$ sire Justin Morgan. Dam, brown; 15 hands high; weight about 1,000 lbs. Sired by Black Snake. He by Prince Lee Boo. Niles horse is a black, $15 \frac{1}{2}$ hands high; weighs about $1,100 \mathrm{lbs}$., with good style and action. He is now owned by Daniel Niles.

\section{NICHOLAS}

Was foaled in 1853, in Norfolk, Coun. Sired by "Raven," g sire, Black Hawk, $g$ g sire, Sherman, $g \mathrm{~g} g$ sire, Justin Morgan. Owned by Harman Hamlin, Canton, N. Y.

\section{NIMROD}

Was foaled in 1824. Sired by True American, and he by Quicksilver. Dam a bay, sired by Justin Morgan, g dam an English mare. He was jet black; $15 \frac{1}{4}$ hands high, and weighed 1,150 lbs. Was a horse of good style and action, and left some excellent stock. He died at East Berlzshire in May, 1854, where he had been kept for serenteen years, by Mr. Joseph Smith.

\section{ONE-EYE}

Was foaled May 20th, 1834, the property of Moses Chamberlain of Bradford, Vt. Sired by Bulrush, g sire, Justin Morgan. Dam by "Postboy." This horse is $14 \frac{1}{2}$ hands high, weighs 975 lbs., and is of mahogany bay color. A very fine horse, good style and action. Stepped light, but was not fast; was liept as a stock horse in New Jersey. Lost one eye when two years old, the consequence of a boy throwing a stone at him. In 1846 Geo. W. Kilburn, now living at Papermill Village, N. H., bought him of Rufus Calhoun, and kept him till 1852, when he sold him to Joseph Peters of Bradford, Vt., and from Peters he went to New Jersey.

\section{ORLEANS FLYING MORGAN}

IVas foaled in 1849 , the property of Dr. Samuel Richmond, of Derby, Vt. Sired by Royal Morgan, g sire, Sherman, g g sire, Justiu Morgan. Dam, a dark bay, sired by Gifford. He is $14 \frac{1}{2}$ 
hands high, and weiglıs 975 lbs.; color, bright bay; white hind feet, and a little white in the face. A very lively, active horse, of fne style. His stock excellent, and sell well.

\section{OLD MORRELL HORSE}

Was foaled about 1830, the property of Mr. Morell. Sired by Woodburv.

\section{PIKE HORSE}

Was foaled the property of Plilander Robbins, of Chelsea, Vt. Sired by Clarke horse, g sire, Woodbury, g g sire, Justin Morgan.

\section{PUTNAM HORSE}

Was foaled in 1825, the property of Putnam \& Hitchcock, of Bethel, Vt. Sired by Woodbury, g sire, Justin Morgan. Dam, an English blood mare, bred by Col. Ray, of Fort Ann, N. Y., and called Nancy, sired by the celebrated horse Chanticlcer, g dam by Imported Messenger. Ho was kept in Bethel and neighboring towns most of his life, and dicd in June, 1855, the property of David W. Cowdry, of Tunbridge, Vt. Weight 1,000 lbs. ; dark chestnut color, with a few white hairs in his face between the eyes. A fine horse, and left excellent stock. Style, action and appearance much like Woodbury. Was regarded as one of the best of his sons.

\section{PAUL CLIFFORD}

Was foaled in 1843. Sired by Black Hawk, g sive. Sherman, $g \mathrm{~g}$ sire, Justin Morgan. Dam by Young Hamiltonian. He by Bishop's Hamiltonian, and he by Imported Messenger. Grand dam by Leonidas, an imported horse. Color, mahogany bay, $15 \frac{1}{2}$ hands high. Now owned by Messrs. Hunsden \& Wilcox, of Oswego, Tioga Co., N. Y. He is a very fine horse, and received the first premium at the National Fair, Springfield, Mass, in 1854.

\section{PRINCE ALBERT}

Was foaled in June, 1846, the property of Toel Hayward, of Ashby, Mass. Sired by Green Mountain $2 d, g$ sire, Gifiord, $g$ g sire, Woodbury, $g \mathrm{~g} g$ sire, Justin Morgan. Dam by Messenger; $14 \frac{1}{2}$ hands high ; weight, 1,000 lbs.; color, bay. Prince Albert is dark chest. 
nat, $14 \frac{1}{2}$ hands high, weighs 1,010 lbs. His style and action are very spirited. $\mathrm{He}$ is pleasant-tempered and very playful. His stock is good and sell well. He was kept in Malone, N. Y., in the season of 1854 and ' 55 , and is there at this time, but is owned by S. F. Wright, Nashua, N. H.

\section{PEACOCK MORGAN}

Was foaled in 1851, the property of Hon. Milo Bennett, of Burlington, Vt. Sired by Royal Morgan. Dam, a high-blood Woodbury Morgan mare. Peacock is $14 \frac{1}{2}$ hands high, weighs 925 lbs. ; color, rery dark chestnut. He is lively, pleasant, full of action and easily controlled; is a compact, hardy horse, with excellent limbs, fine style, and a pleasant driver. Still owned by Mr. Bennett, Burlington, Vt.

\section{PLATO}

Was foaled in 1851, the property of Messrs. Grosvenor, of Shoreham, Vt. Sired by Black Hawk, g sire, Sherman, $g$ g sire, Justin Morgan. Dam, a large bay mare by Sir Charles, g dam by Post-boy. Sir Charles was by Duroc. Plato is 16 hands high; a jet black, and meighs 1,100 lbs. . Trotted repeatedly when three years old a half mile in 1.25. Now owned by D. A. Bennett \& Co., of Bridport, $\nabla t$, and is a fine horse. Post-hoy was by imported Diomede. Dam of Sir Charles, by Plato, a son of Importel Messenger.

\section{POPE HORSE}

Was foaled the property of Joseph Pope, of Danville, Vt. Sired by Sherman, $\mathrm{g}$ sire Justin Morgan. Dam, old Poppet, sired by Justin Morgan. Dark chestnut color, small star in forehead, stifle thin, quarters light, back rather long; eye, ear, head and neck exceedingly beautiful; high, sharp withers, roomy chest, fore legs good, hind legs crooked, hocks wide apart and feet close; very high carriage and very spirited. At five years old, sold to a British officer in Camada for a riding horse.

\section{PUTNAM HORSE 2D}

Was foaled in 1815, the property of Benj. G. Putnam, of North Urange, Vt. Sired by Green Mcuntain $2 d$, g sire, Gifford, $g$ g sire, 
Woodbury, g $g$ g sire, Justin Morgan. Dam, a gray ; said to be of Messenger stock. Putnam is fifteen hands high, weighs $1,150 \mathrm{lbs}$; color, dapple gray. Perfectly gentle and well broken; good driver and good under the saddle. Still owned by Mr. Putnam.

\section{PLEASANT GALE}

Was foaled in 1852, the property of Robbins Battell, of Norfolk, Conn. Sired by Black Hawk, Jr., g sire, Black Hawk, g g sire, Sherman, $g \mathrm{~g} g$ sire, Justin Morgan. Dam by Long's Eclipse.

\section{PETERS MORGAN}

Was sired by Mrorgan Chief, g sire, Bulrush, g g sire, Justin Morgan. Dam by Gold Finder.

\section{PRESIDENT}

Was foaled in 1848, the property of $\mathrm{H}$. Crane, now of Albion, Mich. Sired by Black Hawk, g sire, Sherman, g g sire, Justin Morgan. Dam was a large light gray, of Messenger descent, 16 hands high.

President is 16 hands high, weighs $1,050 \mathrm{lbs}$., is jet black, and a horse of firm action and good style. Was sold when six years old, and taken to Napiorville, Ill. When seven years old, he was purchased by $\mathrm{H}$. Benson, of Hinesburgh, Vt. He was awarded the first premium in the class of three years' old stallions, by the Michigan State Agricultural Society; and also the first premium as the best stallion at the Washtenaw Co. Fair, Mich.

\section{PARKS HORSE}

Was sired by Green Mountain 1st, $g$ sire, Sherman, $g$ g sire, Justin Morgan. Color, chestnut; not fast, but in style and action nnt easily surpassed. Weight, 925 lbs.

\section{RANDOLPH MORGAN}

WTas foaled in 1819 or '20, in Randolph, Vt. Sired by Bulrush, $g$ sire, Justin Morgan ; $13_{4}^{3}$ hands high, weight 925 lbs., color bay; stock fine. Was lept in Randolph, Northfield, and neighboring towns. 


\section{RIP VAN WINKLE}

Was foaled in 1852 ; the property of Smith \& Thurber, of Rouse's Point, N. Y. Sired by Black Hawk, g sire, Sherman, g g sire, Justin Morgan. Color black, with stripe in face, and some white on fuet. "Size, large, will make a horse of 1,100 lbs. When 18 months old, he trotted a fourth mile on the ice in $50 \mathrm{~s}$., and when three years old, he trotted one-half mile in $1 \mathrm{~m} .22 \mathrm{~s}$. He is now owned by E. A. North, of Champlain, N. Y."

\section{ROLLAND HORSE}

Was foaled in 1846 ; the property of Ezekiel White, of Topsham, $\nabla t$. Sired by the Bailey horse, g sire, Woodbury, g g sire, Justin Morgan. Dam sired by Carson horse. Height $14 \frac{1}{2}$ hands, weight 975 lbs., color chestunt, white fore fect, and white stripe in face. Now orned by T. \& D. Rolland, of Corintl, Vt. He took the sccond premium in his class, at the last Vt. State Fair. He is a smart trotter, spirited and styiish.

\section{ROBIN}

Was foaled in 1846, sired by Flying Morgan, g sire, Hackett horse, $\mathrm{g} g$ sire, Gifford, $\mathrm{g} g \mathrm{~g}$ sire Woodbury, g g g g sire Justin Morgan. Dam sired by Cock of the Rock. 15 hands high, and sorrel chestnut color. Time on Cambridge Course, $2 \mathrm{~ms}$. $45 \mathrm{~s}$. Sold, in 1854, in Boston, for \$2000. Now owned by Mr. Snow.

\section{ROUNDS COLT}

Was foaled in 1848. Sired by Flying Morgan, $g$ sire, Hackett horse, $g \mathrm{~g}$ sire, Gifford, $g \mathrm{~g} g$ sire, Woodbury, $g \mathrm{~g} g \mathrm{~g}$ sire, Justin Nirorgan. Dan sired by Harris horse. Color black; $15 \frac{1}{2}$ hands high. This horse was sold in New York eity for \$1,500. A quarter cracls was discovered after sale, and he was taken back.

\section{PAMSEY HORSE}

Was foaled in 1839 ; the property of Robert Ramsey, of Derby Vt. Sired by Royal Morgan, g sire, Sherman, g g sire, Justin Morgan. Dam, a chestnut; weight about $900 \mathrm{lbs}$. Ramsey 
horse is a chestnut, $15 \frac{1}{2}$ hands high, weighs 1,100 lbs., with fair style and action. Is now owned West.

\section{ROMEO 1sT}

Was foaled April 30th, 1848; the property of Silas Hale, of South Royalston, Mass. Sired by Green Mit. 2d, g sire, Gifford, g g sire Woodbury, g g g sire, Justin Morgan. Dam sired by Sherman, $\mathrm{g}$ dam a Messenger mare. Mr. Hale kept Romeo until September 2d, 1852, when he sold him to S. H. Edgerly, Esq., of Manchester, N. H., for $\$ 600$. Mr. Edgerly kept him until March 22d, 1854, when he sold him to Fidward C. David, of Dubuque, Iowa; for $\$ 1,500$, and he is now owned by Mr. David. In 1853, Romeo received premiums at the Fillsboro County Fair, N. H., and at the N. H. State Fair, at Manchester. In the Fall of 1854, he received the first premium at Dubuque County Fair, in Iowa. Is a fine horse, and much resembles his sire.

\section{ROMEO 2D}

Was foaled in 1851. Sired by Esty horse. Grand sire, Black Hawk, $g \mathrm{~g}$ sire, Sherman, $g \mathrm{~g} g$ sire, Justin Morgan. Dam of Wsty horse, sired by Old Romeo. Dam of Romeo, a Messenger mare; purchased in Maine.

Romeo is $15 \frac{1}{4}$ hands high, weight 965 lbs., color dark roan. Good-proportioned, and very fast. He received the first premium of $\$ 200$ at the United States' Fair at Boston, in 1855, as the fastest trotting stallion of his class. Of easy and graceful action, and a very fine horse. Now owned by Benjamin Thurston, of Lowell, Mass., the former owner of Black Hawk.

\section{REVENGE}

Was foaled in Claremont, N. H. Sired by Justin Morgan. For further particulars, see Chapter VII.

\section{RAVEN}

Was foaled May 31st, 1848; the property of Robbins Battell, of Norfolk, Conn. Sired by Black Hawk, g sire, Sherman, g g sire, Justin Morgan. Took the first premium in his class, at the Stato Fair in Conn., in the fall of 1855 . He is a very fine horse. 


\section{RISING SUN}

Was foaled in 1850 ; the property of G. V. Cook, of New Haven, Vt. Is a dark chestnut, with a small white spot in the forehead, and one white hind foot.

Sired by Black Hawk, g sire, Sherman, g g sire, Justin Morgan. Dam, said to have both Morgan and Messenger blood. He is $15 \frac{3}{4}$ hands high, and weighs a little less than 1,100 lbs. Limbs are large, muscular and well shaped, and the whole animal well proportioned, possessing abundance of life and vital energy. He is a fine horse. He received the first premium at the Addison County Fair, in 1854. In the autumn of 1855, Mr. Cook took him to Winchester, Scott County, Illinois

\section{ROWEL HORSE}

Was foaled in 1844 ; the property of Moses G. Rowel, of Tumbridge, Vt. Sired by Hebard horse. Dam by Old Morrill, g dam by Woodbury. Bright chestnut, and weighs about $1100 \mathrm{lbs}$. Is a good horse.

\section{ROYAL MORGAN}

Was foaled in 1821 ; the property of Mr. Aldrich, of St. Johnsbury, Vt. Sired by Ṡherman, g sire, Justin Morgan. Dam, known as Aldrich mare, and sired by Justin Morgan. She was a dark bay of remarkably compact form, with great powers of endurance. She produced and nursed a colt the summer after she was 29 years old. He is $13^{3}$ hands high, and when in his prime, and in high condition, weighed 1,000lbs. It is said that in July, 1844, he weighed 1,020 lbs. He is a dark bay, with black legs, mane and tail, and a small star in the forehead. It has been said that he was not sired by Sherman, but by the Batchelder horse. We have taken some pains to satisfy ourselves on this point, and have stated his pedigree according to our convictions. The facts seem to be that the dam of Royal Morgan was coupled with the Batchelder horse, early in the spring of 1820 ; but the following July, the mare not proving in foal, Mr. Aldrich sent her to Sherman, and the following year paid for the services of the latter horse.

IIr. Aldrich sold him, whe colt, and he was taken to Maine, where he was known as Morgan Rattler. In 1829, he was taken 
to Derby, Vt. A few years after this, he became the property of Mr. Crane, who owned him several sears, and became much attached to the horse. A short time previous to his death, Mr. Crane directed that the horse should be carved on his tomb-stone, which we believe lias been done.

Throughout the southern part of Vermont, the horse is known as the Crane horse; about Derby, as the Steele horse, and in some places as the Chamberlain Coit. The administrators of Crane's estate sold the horse to Solomon Steele, Esq., of Derby Line, Vt. In 1847, Mr. Steele, having a good offer for him, was about selling him, when Portus Baxter and Doctor L. Richmond. of Derby, organizad a stock company, of which Mr. Steele was President, and the horse was kept by him. Three or four years since he was purchased by William Baxter, Esq., of Barton, Vt., by whom he is now owned. We saw him in February last; he was turned loose into a yard with several young colts, and although 35 years old, he seemed to trot as readily and easily as any of them, exhibiting much of that elasticity and nervousness of step which characterized him when in his prime.

His head is not very fine; ears only medium; eyes beautiful; neck, crest, withers. shoulders and chest, excellent; back, loins and hips, good, and limbs unsurpassed; mane and tail thick and long, and a little long hair about the limbs. His stock average larger than himself, and are very uumerous in all the northern portion of the State. They are hardy, enduring ; almost invariably good tempered; and free, plensant drivers.

\section{SHERMAN MORGAN IST}

Was foaled in 1835, the property of Moses Cook, of Campton, N. H. Sired by Sherman, g sire, Justin Morgan. The pedigree of the dam not fully established, but conceded to have been a very fine animal, and said to be from the Justin Morgan. Shermau - Morgan is 15 hands high, weighs about 1,050 lbs., is dark chestnut, and rery much resembles his sire Sherman, but heavier, stockier, and not as much action. A fine horse, and is now kept in the stable at Lancaster, N. H., where the Sherman died. He is owned by A. J. Congdon. 


\section{SHERMAN KING}

Was sired by Sherman, g sire, Justin Morgan, color dark bay, with a small star in his forehead, very compact, breast-bone very prominent, head high, and very fine; full of spirit and courage, and excellent action.

\section{STOCKBRIDGE CHIEF}

Was foaled in 1843. Sired by Black Hawk, g sire, Sherman, g g sire, Justin Morgan. Dam sired by Sir Charles. 16 hands high, weight 1,200 lbs, color chestnut. At the State Fair at Providence, R. I., he trotted a mile in 2.44. Is a well proportioned, stronggoing horse. Is now owned by P. W. Bishop, Chatham FourCorners N. Y.

\section{SHERMIAN BLACK HAWK}

Was foaled in 1845, the property of B. J. Myrick, of Bridport, Vt. Sired by Black Hawk, g sirc, Sherman, g g sire, Justin Morgan. Dam by Young Hamiltonian, owned by Allen Smith, Esq., of Addison, Vt., and bred by Judge Larabee, of Shoreham, Vt. Dam of Young Hamiltonian, by Leonidas, $g$ dam by Bellfounder, $\mathrm{g}$ dam of Shcrman Black Hawk by Imported Matchem. $15 \frac{3}{2}$ hands high, weighs 1,080 lbs., color jet black, with small star in his forchead. He has trotted a mile in less than 2.40. Is a compact, well-made, excellent tempered horse, and moves in fine style. Is rery spirited, but perfectly tractable.

\section{SHERMAN MORGAN DEFIANCE}

Tras foaled in 1849, the property of James Morse, of Hareı hill, N. H. Sired by Baston Tiger, $g$ sire, Cock of the Rock, $g \mathrm{~g}$ sire, Sherman, $g g g$ sire, Justin Morgan. Dam by Woodbury. This horse is 16 hands high, weight 1,150 lbs., color black chestnut, fine action and style. When one year old, he was purchased by C. C. Smith, Esq., of Corinth, Vt., who now owus him.

\section{SIR CHARLES}

Was foaled June 29th, 1852, the property of II. W. Bailey, of Nerbury, Ft. Sired by Coos Morgan. Dam by Morrill Mor. 
gan, g dam by Morgan Eagle. Height 15 hands, weight 975 lbs., color blood-bay, easy gaited, with fine style and action, heary set of limbs, pleasant temper, and good horse.

\section{SHERMAN MORGAN 2D}

Was foaled in 1845. Sired by Sherman Morgan 1st., g sire, Sherman, g g sire, Justin Morgan. Dam sired by Flint horse. 14 hands high, weight $950 \mathrm{lbs}$, color dark chestuut. Has a fine figure, easy action, gentle and spirited. Now owned by D. E. Lucy, of Waterbury, Vt., and kept by him for a driving horse.

\section{SCOTT HORSE}

Was foaled in 1840, the property of J. L. Scott, of Newport, Vt. Sired by Royal Morgan, g sire, Sherman, g g sire, Justin Morgaz. Scott horse is a dark bay, 16 hands high, weight little less than 1,200 lbs., a compact well-made horse. He is now owned by Col. Thomas Kent, of Orford, N. H.

\section{SHIRTLIFE HORSE}

Was foaled in 1847, the property of Moses Copp, of Stanstead, C. E. Sired by Royal Morgan, g sire, Sherman, g g sire, Justin Morgan. Dam a bay about 16 hands high, and weighed about 1,000 lbs. Shirtliff horse is a dark bay, 15 hands high, and weighs 1,000 lbs. Has good style, is active and lively. He is now owned in Kalamazoo, Mich.

\section{STRANGER}

Was foaled in 1851, the property of Mr. E. Slater, of Essex, Vt. Sired by Flying Morgan, g sire, Hackett horse, g g sire, Gifford, $\mathrm{g} g \mathrm{~g}$ sire, Woodbury, $\mathrm{g} \mathrm{g} \mathrm{g} g$ sire, Justin Morgan. Dam a large fine animal, said to be a Morgan, was a bay $15 \frac{1}{2}$ hands high, and weighed 1,100 lbs. Stranger is a dark chestnut, $14 \frac{1}{2}$ hands high, weight $900 \mathrm{lbs}$. He is compact and muscular, very playful and active. In February, 1855, he trotted at Hillsborough, N. Y., with several horses, for a purse, making time in 2.58 , and beating all horses of his age, though beaten by a six years' old. Stranger 
is a fine horse, and gives promise of being fast. Sold, in Febrnary, 1855 , to Dr. H. Renson, of Hinesburgh, who now owns him.

\section{STEVENS HORSE}

Was bred in Piermont, N. H., by Moses Larned. Sired by One Eye, gr sire, Bulrush, $g$ g sire, Justin Míorgan. Bay color, weight 975 lbs. Was taken to Rhode Island. A fast horse. He was advertised as raised by Jesse Johnson \& Brothers, but he was nct.

\section{SELINI}

Was foaled June 2, 1844, the property of J. Gibson, West Cambridge, Mass. Sired by Black Hawk, gire, Sherman, $g \mathrm{~g}$ sire, Justin Morgan. Dam sired by Romeo. Selim is $15 \frac{1}{2}$ hands high, and weighs a little under 1,100 lbs. His body is dark roan, with black legs, mane, and tail. He is a good horse, and his stock prove good. He is now owned by Jeremiah Gilson, at West Cambrilge, Mass.

\section{SMITH MORGAN}

Was foaled in June, 1850, the property of John Robinson, of Antrim, N. H. Sired by Flint horse, g sire, Sherman, g g sire, Justin Morgan. Dam a fine mare, owned by John Robinson, of Antrim, N. H., known as the Robinson mare. This horse is light chestnut color, $16 \frac{1}{2}$ hands high, form good, limbs heavy, and weighs 1,310 lbs. He is a showy, handsome traveller. His stock prove good.

\section{SAWYER HORSE. \\ (SEE YOUNG BURBANK ;) \\ (OR MORGAN TRAVELLER.)}

\section{SEARCHER}

Was foaled in 1847, the property of Samuel Moore, of Shoreham, Vt. Was sired by Barney Ilenry. Dam sired by Gifford, and noted for her speed and enduranec. Searcher is a dark bay, with black legs, mane, and tail, and no white hairs; is nearly 17 hands high and weighs over 1,200 . When four years old, he received the first premium, in his class, at the Addison County Agricultural Fair. He has a beautiful coat, a bold, fearless style of movement, and ex- 
cellent action for a horse of his size. In the autumn of 1851 , be trotted a mile, at Middlebury, in less than three minutes, although untrained. He is a very fine horse, and is now owued by Minor Andrews, Esq., of Franklin Mills, Portage county, Ohio, where he is acquiring an excellent reputation.

\section{TWIN MORGAN}

Was foaled in 1840 or ' 41 ; the property of Dix Whitney, of Brookfield, Vt. Sired by Bulrush, g sire Justin Morgan. Dam, a large coarse brown mare, deficient in constitution. Twin Norgan weighs 950 lbs.; head a little low, color brown; a very fair horse. Went to N. H.

\section{TAYLOR HORSE}

Was foaled the property of James Taylor, of Bolton, C. E. Sired by Royal Morgan, g sire Sherman, g g sire Justin Morgan. Dam, a bay, about 16 hands high ; weighed about 1,100 lbs; descended from Le Boo. Taylor is a blood bay, 14 hands high, and weighs about 1,000 lbs.; style and action good.

When two years old, Mr. Taylor sold him to R. Bowker, Esq., of Mansonville, C. E., who now owns him.

\section{TECUMSEH}

Was foaled 25th May, 1851 ; the property of H. F. Griffith, of 'Tunbridgc, Vt. Sired by Black Hawk, g sire Sherman, $g$ g sire Justin Morgan. Dam by Young Bulrush 1st, $g$ dam by Morgan Eagle, $\mathrm{g} g$ dam by Ainsworth horse, $\mathrm{g} \mathrm{g} g$ dam by Justin Morgan. Tecumseh is a dark mahogany bay, $14 \frac{1}{2}$ hands high, and weighs 975 lbs. Received the first premium in the class of "Morgan Crosses," when entered as three year's old at Vt. State Fair, at Montpelier. He is now owned by H. F. Griffith, of Tunbridge, $V t$., and is a horse of very fine action and style.

\section{TURNER'S BLACK HAWK}

Was foaled June 22d, 1848 ; the property of S. T. Turner, or Lewis, Essex Co., N. Y. Sired by Black Hawk, g sire Sherman, $\mathrm{g} g$ sire Justin Morgan.

Dam was a beautiful bay, weighed about 1,050 lbs., and was bred 
by Payne Turner, Esq., of Essex Co., N. Y. Turner's Black Hawk is a mahogany bay, $15 \frac{1}{2}$ hands high; weighs 1,100 lbs.; has good action and fine style. He is now in Xpsilanti, Nichigan.

\section{VERMONT MORGAN CHAMPION}

Was foaled about 1826 ; the property of Mr. Woodruff, of Jefferson, N. H. Sired by Sherman, g sire Justin Morgan. He was 15 hands high, and weighed 1,150 lbs. ; color, black; a horse of great action, and a capital roadster. Could trot a mile in 3 minutes. High carriage and smooth light morement. He was afterwards owned by Judwine \& Houghton, of Hardwick, Vt., and sold by them to Mr. Lansing, of Lansingburgh, N. Y. Was purchased and taken to Danville, Vt., in 1845, where he was kept till he died in 1846. He had a fine head, and slightly Roman nose. His stock command a high price, and many are fast.

\section{VERMONT}

Was sired by Gifford, $g$ sire Woodbury, $g \mathrm{~g}$ sire Justin Morgan. Dam, sired by Green Mountain 2d, g dam Phebe ; owned by J. L. Woods. She was sired by a horse known in Mass. as Tom Molgan, and noted for lis, speed and bottom. Tom Morgan was by True Briton. Termont receired the first premium in his class at the State Fair in Brattleboro, in 185̃. He is dark chestnut, 14 hand's high, weighs 950 Ibs. A rery close, compact made horse. Now owned by Joseph Peters, of Bradford, Vt.

\section{VERMONT 2D}

Was foaled the property of Thomas Randall, of Danville, Vt. Sired by Morgan Comet, g sire Sherman, g g sire Justin Morgan. Dam by Sherman, g dam by Justin Morgan, lnown as the Woodman mare. Vermont $2 d$ weighs 925 lbs., is 14 hands high, and of dark chestnut color. Head, eye and ear beautiful; throat and jowls very fine. Close, compact horse ; spirited and active; stylo not so high as some. Now owned by Danford Carpenter, of Willoughby, Lake County, Ohio, and is a valuable animal.

\section{VERMONT CHAMPION}

Was foaled June 26th, 1844. Sired by Vermont Míorgan Champion, 
g sirc Sherman, $g \mathrm{~g}$ sire Justin Morgan. Dam, a thick-set Dutch mare; weighed about $1,100 \mathrm{lbs}$. Vermont Champion is black, 15 hands high, and weighs $975 \mathrm{lbs} . \mathrm{He}$ is a fine traveler, can trot a mile in 3 minutes, and is a very fast walker. Limbs good size, flat, bony, and muscular. Neek long and thick ; ears short and lively; he has a Romau uose. He is now kept in Marshfield, Vt., and is owned by George M. and Benjamin Town.

\section{VERMONTER}

Was foaled in 1849 ; the property of Robbins Battell, of Norfolk, Conn. Sired by Blaek Hawk, g sire Sherman, g g sire Justin Morgan. Dam, an Lnglish mare. Sold to William Starr, Esq., of Burlington, Iowa. He is a very fine horse, and we understaud was sold by Mr. Starr, in the spring of 1856 , for $\$ 1,800$.

\section{VERIONT MORGAN.}

\section{(SRE TILLY COLT.)}

\section{VERMONT CHIEF}

Was foaled June 24th, 1848; the property of Smith F. Kelley, of Pittsford, Vt. Sired by Black Hawk, $g$ sire Sherman, $g \mathrm{~g}$ sire Justin Morgan. Dam, sired by a Messenger horse called Majesty, $\mathrm{g}$ dam by Magnum Bonum, $g \mathrm{~g}$ dam by imported Yellow Bird. Vermont Chief is a dark chestnut, 154 hands high, and weighs $1,075 \mathrm{lbs}$. The has a good figure and a good style of movement. He received the first premium in his class when three years old, at the Rutland County Agricultural Fair, and the second premium at the Vermont State Fair, in 1855. He is now owned by Elisha $\mathrm{S}$. Kelley, Danby, Du Page county, Illinois.

\section{WOODBURY 2D}

Was foaled June 21st, 1847, the property of Luke Havens, Esq., of New Haven, Vt. Sired by the Wheeler horse, g sire, Hackett horse, g g sire, Giford, g g g sire, Woodbury, g g g g sire, Justin Morgan. Dam, a grey of medium size, sired by Hackett horse, $\mathrm{g}$ dam by Woodbury. Woodbury $2 \mathrm{~d}$ is a beautifully dappled gray, $14 \frac{1}{2}$ hands himh, and has weighed 1,020 lbs., but his fair average 
weight is $950 \mathrm{lbs}$. His neck is rather longer than is usual in the breed. His style is excellent, and he is a light, easy-stepping horse, full of vigor and action. He is now owned by Joshua Scott, Esq. Vergennes, $V$ t.

\section{WHEELER HORSE}

Was foaled in 1844, the property of Mr. Mead, of Cornwall, Vt. Sired by Hackett horse, g sire, Gifford, $g$ g sire, Woodbury, g g g sire, Justin Morgan. Dam sired by Gifford. When a suckling colt he was sold to Col. Nash, of N $\mathrm{ew}$ Haven, Vt., who soon after sold him to Freeman Wheeler, of New Haven. Wheeler horse is about 14 hands high, of a dark chestnut color, and weighs about 950 lbs. Ile is an exceedingly active, bardy, and vigorous horse. In 1854: Mr. Wheeler took him to Wisconsin.

\section{WHITE MOUNTAIN}

Was foaled in 1852, the property of S. H. Edgerly, of Manchester, N. II. Sired by Green Mountain 2d, $g$ sire, Giford, $g \mathrm{~g}$ sire, Woodbury, g $g \mathrm{~g}$ sire, Justin Morgan. Dam by Brooks horse, $\mathrm{g}$ dam by Cock of the Rock. Height, 15 hands; weight, 975 lbs. ; color, dark chestnut. -Time, 2 min. 50 sec. A very pleasant-tempered horse, of good style, and a good driver. Still owned by Mr. Edgerly.

\section{WILEY COLT}

Was foaled in 1818, the property of Mr. Hutton, of Canton, St. Lawrence Co., N. Y. Sired by Mountain Eagle, g sire, Sherman, $g$ gr sire, Justin Morgan. Lam by Barnum's Cock of the Rock. Wiley Colt is a fine baj, black mane, tail, and legs, $15 \frac{1}{2}$ hands high, and weighs $1,050 \mathrm{lbs}$. When a suckling colt Hutton sold him to Mr. Wiley, of Canton, N. Y. In August, 1853, Mr. Wiley sold him to Hon. Milo Bennett, Burlington, Vt., who sent him to Virginia, and lept him in Augusta County till the autumn of 1855, when he sold him to a company at Greensburgh, Penn.' He was a prime horse, and his stock is good.

\section{WELLINGTON HORSE}

Wns foaled in Jume, 1853, the property of Nathan Stone, of New Ipswich, N. H. Sired by Comet, $\mathrm{g}$ sire, Billy Root, $\mathrm{g} g$ sire, Sher- 
man, $g \mathrm{~g} g$ sire, Justin Morgan. This horse is $\mathbf{1 4}$ hands high, and weighs 900 ibs.; color, light chestnut, with light mane and tail. His form and action very like his sire, Comet. He is now owned by Mr. Oliver Wellington, Phillipstown, Mass.

\section{WHITE MOUN'TAIN MORGAN}

Was foaled in 1834, the property of John A. Willard, of Lancaster, N. H. Sired by Sherman, $g$ sire, Justin Morgan. Dam, an English blood mare, weighing 1,150 lbs. White Mountain Morgan is $15 \frac{1}{4}$ hands high, and weighls 1,100 lbs.; color, dark chestnut. He has been kept most of his life at St. Johnsbury and vicinity. He is a very compact, well-shaped horse, excellent head and neek, fine style of movement, and a good traveler, but not so much spirit as some. A very hardy and enduring horse. His stock are not dcficient in spirit, and many of them have a great deal of life, and are generally excellent animals. He is now owned in Townsend, Vt.

\section{WILD-AIR}

Was foaled in 1850, the property of Lyman Pease, of Bridport, Vt. Sired by Black Hawk, gु sire, Sherman, gr g sire, Justin Morgan. Dam, a large, powerfil mare, sired by Harris' Hamiltonian; $15 \frac{3}{4}$ hands high ; weight, 1,100 llbs. ; black color, with three white feet, and a star in his face. Went to Ohio in the spring of 1856. He is a fine horse.

\section{WINDSOR MORGAN}

Was foaled the property of Charles W. Barker, of Henniker, N.H. Sired by Burbank horse, $g$ sire, Woodbury, $g \mathrm{~g}$ sire, Justin Morgan; 15 hạnds high; weight, 1,095 lbs.; color, dark bay. Went to Wisconsin when very old.

\section{WAY IIORSE}

Was foaled in 18t9, the property of Joseph Way, of Derby, Vt. Sired by Royal Morgan, $g$ sire, Sherman, g g sire, Justin Morgan. Dam, sired by Woodbury. Way horse is a blood bay, 14 hands high, and weighs $975 \mathrm{lbs}$. His mane and foretop are very heary, the former nearly three, and the latter nearly two feet long. Style and action good. 


\section{WOODBURY}

Was foaled in 1816. Sired by Justin Morgan. For further particulars, sec Chapter Seren.

\section{WALKER HORSE}

Was foaled in 1835, the property of Wm. Walker, of Hartland, Vt. Sired by Woodbury, ge sire, Justiu Miorgan. Dam by Tally Ho. Valker horse is 16 hauds high, and weighs about 1,300 lbs.; blood bay, with black mane and tail ; strong, compact, and muscular horse. Style and action good for one of his size. Still owned by Mr. Waller.

\section{IVHALEBONE,}

Formerly known as the Clark horse, was foaled about the year 1827, the property of $\mathrm{Mr}$. Bradley, of Fryeburg, Maine. Was sired by Sherman, $g^{*}$ sire, Justin Morgan. Chestnut color, 15 hands high, and weighs 975 lbs. He was the sire of Whalebone, who, in double harness, with Lantern, trotted a match on Long Island, in June, 1855, against Stella and Alice Gray, mile heats, beating them, in 2 min. 42 sec.

He has the reputation of being a fine horse; but we are unable to give any more particulars concerning him. He is now owned in Turner, Maine.

\section{YOUNG BURBANK 1sT}

Was foaled in 1835, the property of David Tucker, of Newbury. Vt. Sired by Woodbilry, g sire, Justin Morgan. Dam sired by Post-boy. Sold, when sucking, to Joseph Sawyer, of Nerbury, who liept him till he was six or seren years old, and sold him to Mr, Farrar, of Bucksfield, Maine, who, we think, has him now. Height 14:1 hands; weight, nearly 1,100 lbs.; color, chestnut. Good style and action, and a good stock horse.

\section{YOUNG BULRUSH 2D}

Was foaled in 1835, the property of Ellis Bliss, of Bradford, Vt. Sired by Bulrush, g sire, Justin Morgan. Dam a good mare and fast trotter, brought from Maine.

Young Bu'rush 2d was 16 hands high, and weighed 1,200 lbs. 
Color, bright bay. Style not so good and built not so compact a: some, but high-spirited and a good roadster. He was a fast trotter, and one of the strongest-going horses. Weut South, when young.

\section{YOUNG BULRUSH 3p}

Was foaled in 1843, the property of Evan Collis, who kept him during his life. After his death the administrators of his estate sold him to Edwin Collis, in 1855. Sired by Bulrush, g sire,

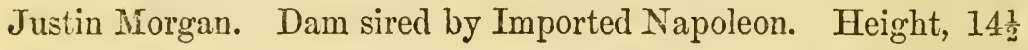
haads; woight, 975 lbs.; color, dapple gray. Very good horse.

\section{YOUNG BULRUSH 4TII}

Was foaled in 1843, the property of Thomas Worthin, of Thetford, Vt. Sired by Bulrush, g sire, Justin Morgan. Dam by Cincinnati Morgan. Now owned in Roxbury, Mass., by Mr. Martin ; $14 \frac{1}{2}$ hands high ; weight, 950 lbs. ; color, dapple gray.

\section{YOUNG AMERICA}

Was foaled in June, 1851. Sired by Farmers' Beauty, g sire, Gifford, $g$ g sire, Woodbury, $g \mathrm{~g} g$ sire, Justin Morgan. Dam, a black, by Sherman. Young America is 15 hands high; weighs 1,000 lbs., and is a jet black, Good style and action. Is now owned by Johu S. Carr, of Goffstown, N. H. Time, 3.5.

\section{YOUNG AMERICA 2D}

Was foaled June 17th, 1852, the property of J. Ide, of St. Johnsbury, Vt. Sired by Billy Root, 8 sire, Sherman, $g$ g sire, Justin Morgan. Dam sired by Green Mountain 1st, g dam by Bailey horse. Height, 15 hands; weight, 950 lbs.; color, dapple chestnut. The first premium on Sherman Morgans of this class, was awarded to him at the State Fair, at Montpelier, 1853. Symmetrical figure, and very good action.

\section{YOUNG MORGAN EMPIRE}

Was foaled July, 1852, the property of Jonas Cutter, of Jeffrey, N. H. Sired by Morgan Empire, g sire, Green Mountain 2d, g g sire, Gifford, $g \mathrm{~g} g$ sire, Woodbury, $g \mathrm{~g} g \mathrm{~g}$ sire Justin Morgan. Dam sired by Flying Morgan. 


\section{YOUNG MOIRGAN ECLIPSE}

Was foaled in 1853, the property of Jesse Johnson \& Brothers, of Bradford, Vt. Sired by Morgan Eclipse, g sire, Morgan Cæsar, $g$ gire, Woodbury, $g$ g $g$ sire, Justin Norgan. Dam by Young Norgan Emperor, g dam by Bulrush. 'Took the first premium in his class at the Vermont State Fair, in 1855.

\section{YOUNG BURBANK 2D}

Was foaled in 1851, the property of Charles W. Barker, of Hillsborough Bridge, N. H. Sired by the Barizer horse, g sire, Woodbury, $g g$ sire, Justin Morgan. Dam sired by a son of Sherman. Dark chestnut color ; weighs 975 lbs. Still owned by Mr. Barker.

\section{YANKEE BOY}

Was foaled $3 d$ of June, 1852, the property of Hisvey Iale, of Middlebury, Vt. Sired by Morgan Henry, g sire Barney Henry. Dam by Hackett horse; 15 hands high; weight, $975 \mathrm{lbs}$; color, bay. A very pleasant-tempered and good-moving horse. In 1855 Mr. Yale took him to Franklin Grore, Lee Co., Illinots, where he now is.

\section{YOUNG BLACK IIATK}

Was foaled in 1843, the property of James Smith, of Sharon, N. H. Sired by Black Hawk, g sire, Sherman, gु g Jistin Morģan. Dam, a deep bay, raised in Pennsylrania, and sired by the trotting horse Andrew Jackson. Fonng Black Hawk is a coal black, $15_{2}^{1}$ hands high, and rreighs 975 los. He has a good figure and excellent spirit and action. Time 2.50. Is now owned by J. E. Maynard, Lowell, Mass.

\section{TOUNG MORGAN EMPEROR}

Was foaled the property of Mr. Woods, of Haverhill, N. H. Sired by Emperor, g sire, Bulrush, $\mathrm{g} g$ sire, Justin Morgan. Dam by North Star. Fe is a blood bay, 14.1 hands high, weighs 1,025 pounds. Is a compact, good moving and excellent horse. He is now owned by Jonas Cutter, of Jeffrey, N. H

\section{IOUNG CESAR}

Was foaled the property of Jesse Johuson \& Brothers, of Brad $13 \%$ 
ford, Vt. Sired by Morgan Crasar, g sire, Woodbury, g g sire, Justin Morgan. Dain by Morgan Emperor. He was $15 \frac{1}{2}$ hands high, waighel 1,075 lbs. and his color a dull black. He was a good horse. He died at Guildhall, Vt., in 1853, the property of I. W. Smith.

\section{YOUNG FLYING MORGAN}

Was foaled in 1851. Sired by North Star, g sire, Morgan Emperor, $g$ g sire, Bulrush, g g g sire, Justin Morgan. Dam a Morgan mare, sired by Flying Morgan. Weight, 960 lbs.; color, bright bay. Now orved by Benj. M. Glines, of Byfield, Mass. Time, 2.45.

\section{YOUNG HUBBARD}

Was sired by Latham Horse, $g$ sire, Woodbury, $g \mathrm{~g}$ sire Justin Morgan. Dam by Giiford. Weight, 1,025 lbs.; color, chestnut. Mr. Hubbard bought him of Judge Blodgett, of Chelsea, Vt.

\section{YOUNG LATHAM}

Was foaled the property of Beyer Latham, of Lyme, N. H. Sired by Latham horse, $g$ sire Woodbury, $g$ g sire, Justin Morgan.

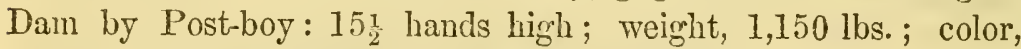
chestnut; good action, and a fine stock horse.

\section{YOUNG MORRILL}

Was foaled in 1848, the property of Mr. Smith, of Cabot. Vt. Sired by Morrill horse, $g$ sire, Jennison Korse, $g$ g sire One Eye, g g g sire, Bulrush, g g g g sire, Justin Morgan. Dam sired by Sherman ; 16 liands high; weight, 1,160 lbs.; color, dark brown. Mr. Smith sold him, when three years old, to Mr. Morrill, and Morrill to Messrs. Town \& Trowe, Barre, Vt. He received the first premium at Vermont State Fair, at Montpelier, 1853 ; also the first premium among Bulrush Morgans, at Rutland, 1855. Was then taken to the National Exhibition at Boston, Oct., 1855, and entered in class for general use, where he received the first premium of $\$ 200$, Time, 2.38. A heavy, close, compact and enduring horse.

YOUNG BULRUSH.

(SEE OXE EYE, also, ALLEN HORSE) 
PEDIGREES.

(OMITted IN PP. $273,27 \tau, 304$. )

\section{COI. FREMONT}

Was foaled June 16, 1855, the property of Linsley Brothers, Wrest Meriden, Conn. Sired by Black Hawk, g sire, Sherman, g g sire, Justin Morgan. Dam, Black Lilly, sired by Old Jake. He is light chestnut, witl small white stripe in the face, and is a promising colt.

\section{ENTERPRISE}

Was foaled June 6, 1852, the property of Messrs. Maury \& Gilman, Nashua, N. H. Sired by Romeo, g sire, Green Mountain 2d, $\mathrm{g}$ sire, Gifford, $\mathrm{g} g \mathrm{~g}$ sire, Woodbury, $\mathrm{g} \mathrm{g} \mathrm{g} \mathrm{g}$ sire, Justin Morgan. Dam sired by the Flint Horse.

Enterprise is a light chestnut, 15 hands high, and weighs 915 lbs. Is a sinooth-built, stylish, free, pleasant-tempered horse, and is still owned by Messrs. Maury \& Gilman, at Nashua, N. H.

\section{PATHFINDER}

Was foaled June 21, 1851, the property of Linsley Brothers, West Meriden, Conn. Sircd by Black Hawk, g sire, Sherman, g $g$ sire, Justin Morgan. Danı, Mary Hunter, sired by Roscoe. Patbfiuder is a very dark chestnut, 16 hands high, and weighs 1,125 lbs. $\mathrm{He}$ is a free, showy driver, and though never trained, can trot in three minutes. Is a fine horse, and still the property of Linsley Brother's.

\section{BLACK HATK SHERMAN}

Was foaled July 1st, 1849, at Clarenceville, Canala East. the property of Geo. WV. Johnson. Sired by Black Hawk, g sire, Shrıman Morgan, $g$ g sire, Justin Morgan ; dam by Black Snakc. He is $15 \frac{1}{2}$ hands high, weighs $12661 \mathrm{bs}$, , color black, with small star in the forehead, tail and mane long and wavey. Is a horse of very superior style and action, has never been trained, can trot his mile in 3 minutes. His limbs broad and flat, carrying the width well down below the knce. Was purchased for the Brownsvilie, Fayette Co., Pa., Mo:gan Horse Co., by two of their members, Messrs. James Slocum and W/n. Elliott, at the Vermont State Fair at Montpelier, in Sejtember, 1853. 


\section{APPENDIX.}

Thie following pedigrees of stallions of some note, although not Morgans, are given because they have been mentioned in the preceding chapter, or have left a good deal of valuable stock, and their blood been more or less mingled with that of some horses called Morgan.

\section{COCK OF THE ROCK}

Was foaled in 1814, and bred by Nathaniel Coles, of Long Island. He was sired by Duroc, $g$ sire, Imported Diomed. His dam, Romp, was full sister to Miller's Damsel, the dam of American Eclipse, and was sired by Messenger; his $g$ dam, the imported Pot8os, mare, bred by Lord Grosvener, sired by Pot8os, and Pot8os by the great Eclipso; his $\mathrm{g}$ dam, by Gimcrack, his $\mathrm{g} g$ dam, by Cripple, and Cripple by the Godolphin Arabian. Cock of tho Rock ran sereral successful four mile races against good horses, but was beaton by Betsey Richards, on Long Island, and by Sir Walter at Montrenl. About 1820, he was purchased by Gen. Barnum, of Vergennes, Vt., who took him to that place and kept him until 1828 or' 29 , when to sold him, and he was taken to Tenuessee, where he died.

\section{SIR WAITER}

Was sirel by Hickory, $g$ sire, imported Whip, $g \mathrm{~g}$ sire, Saltram, $\mathrm{g}$ $\mathrm{g} g \mathrm{~g}$ sire, English Eclipse, dam, Nettletop, by Diomed. He was not kept in this State, but in Canada near the line. He was an exccllent four mile racer.

\section{QUICKSILTER.}

The Quichsilver referred to in the foregoing pages is not the Quicksilver of the Stud Bool, first called Suap and sired by Mcdley, but 
is another horse of the same name, bred by Gorham Parsons, of Walpole, New Hampshire, and sired by Dey of Algiers, an Arabian.

\section{CARSON HORSE.}

This horse acquired some celebrity in the eastern part of the State, on account of his stock. We know little of him, except that he was sired by Quicksilver.

\section{HENRY}

Was, we believe, a thorough-bred horse, but we are unable to give his pedigree. He was a fine animal, and received several premiums in New York and elsewhere. He was kept near Lake Champlain until about 1850. He left some good stock.

He was a beautiful bay, of good size and fine action.

\section{YOUNG HAMILTONIAN}

Was bred by Judge Larabee, of Shoreham, Vt., sired by Bishop's Hamiltonian, and he by imported Messenger. Dam, by Leonidas, g dam, by Bellfounder.

Young Hamiltonian was long owned by Allen Smith, Esq., of Addison, Vt. He was a blood bay, about $15 \frac{1}{2}$ hands high, and left some good stock. We are unable to give the blood of the dam of Rishop's Hamiltonian.

\section{BARNEY HENRY,}

Or the Hatch Hill Henry, as he is sometimes called, has long been owned by George Barney, of Whitehall, N. Y., and is now over twenty years old.

He has aequired well merited fame on acenunt of the excellencs of his stock, which usually have plenty of bone and muscle, are hardy, spirited travellers but are not always kind and gentle. In his adrertisement, Mr. Barney states that he was " sired by Signal, out of a Messenger mare." But what was the blood of Sigual we do not know. It has often been said that Signal was a thoroughbred horse, raised by L. G. Morris, Esq., of Fordham, N. Y., but Mr. Morris informs us that he never raised or owned such a horse. 
Whatever be his peligree, he has proved himself a very fine horse, as his appearance indicates.

ITe is a dapple bay, 16 hands high and weigins about $1150 \mathrm{lbs}$. He is now owned in Hubbarton, Vt.

\section{POST BOY, BY GABRIEL,}

Was foaled in 1800, the property of Mordecai Hall. Sired by Gabriel; an imported horse bred by the Earl of Ossory, and sired by Dorimont, his dam by Highflyer, $g$ dam, by Snap.

Gabriel was brought to Maryland in 1779 , and lived but one year. Post Boy was purchased by Gen. Ridgley, who trained and ran him with much success, beating many of the best horses of his day. among them Hamlintonian, Miller's Damsel, First Consul, Maria, and Lavinia. In Oct. 1809, in a race at Washington, with Hickory, he fell, broke his leg, and soon aiter died. He was never kept for stock, and we believe, left no descendants; and we give his pedigree and this description of him because he has been confounded with Post Boy, the distinguished son of Henry, and his pedigree sometimes given when the latter horse is meant.

\section{POST BOY, BY FENRY,}

Was foaled in 1831, sired by Henry, dam, Garland, by Duroc, was a chestnut horse, of much note and a suecessful racer. He was never kept in this State, but some of his descendants have been 'The few horses we have seen of this stock were light limbed, and light bodied, with fine heads, and light, graceful action; but not remarkable for hardiness or endurance.

\section{SIR CHARLES}

Was foaled about 1815, the property of James Cock, of Oyster Bay, Long Island. Sired by Duroc, $g$ sire, Diomed, $g \mathrm{~g}$ sire, Fiorizal, $g$ g g sire, King Herod; dam, by Plato, and he by Messenger, $\mathrm{g}$ dam, part thorough-bred, but her pedigree is not known.

When six years old he was purchased by David Hill, Esq., of Bridport, Vt., and kept by him many years. 
When very old, Mr. Hill's son took him to Madison County, N. $\mathbf{Y}$., where he died. He was a blood bay, with black legs, mane and tail, and $15^{\frac{1}{2}}$ hands high; was a bold-looking, fine-moving horse, and left some good stock.

Some of the descendants of the celebrated rivals, Henry and Eclipse, being scattered throughout all the Northern States, their pedigree may be found convenient as a matter of reference, though we do not know of any immediate deseendants of these horses that have been owned in this State.

\section{ECLIPSE}

Was foaled at Dosoris, Queens County, Long Island, on the 25th of May, 1814, the property of Gen. Nathaniel Coles. Sired by Duroc, g sire, Diomed, g $g$ sire, Florizel, g g g sire, King Herod ; dam, the celebrated Miller's Damsel, by imported Messenger, g dam, the English Pot8os mare, sired by English Eclipse, g g dam, by Gimeraek. When five years old he was purehased by Mr. Van Ranst, who was his entire or principal owner, during the whole of his racing career.

He was chestnut, with a star in his forehead, and near hind foot white. Was $15 \frac{1}{2}$ bands high and a compact heavy limbed horse.

As a raeer he was one of the most suceessful that ever appeared on the turf in this country, beating in the eight raees whieh he ran some of the most celebrated horses of his time; Sea Gull, Little John, Fearnought, Lady Lightfoot, Flag of Truce, Sir Walter, Sir Charles and Heury.

\section{HENRY}

Was foaled the 17th of June, 1819, the property of Lemuel Long, near Halifax, North Carolina. Sired by Sir Arehy, g sire, Diomed, $g$ g sire, Florizel, $g \mathrm{~g} g$ sire, King Herod; dam by Diomed, g dam, bj Bell-air, $g \mathrm{~g}$ dam, by Pilgrim, $\mathrm{g} g \mathrm{~g}$ dam, Valiant, $\mathrm{g} g \mathrm{~g} g$ dam by Janus, $g \mathrm{~g} g \mathrm{~g} g$ dam, by Jolly Roger, who was imported into Virginia. Jolly Roger was sired by Roundhead, a son of Flying Childers.

Henry was a chestnut, with small star in the forehead and one hind foot white, his mane and tail was about two shades lighter 
than his body ; fourteen hands three and a half inches high-was symmetrical, compact, pony-built horse, and left some good stock, of which the most noted was Post Boy.

Though not as much esteemed as a racer or breeder as some of the sons of Sir Archy, he was yet a very fine horse, and gained a lasting reputation by his contest with Eclipse, in which, although beaten, he made the first heat of four miles in $7 \mathrm{~m}$. $37 \mathrm{~s}$., which was then and for many years after, the quickest time on record.

\section{WILDAIR}

Was foaled in 1753, and was imported by Mir. DeLancey, in 1763 or 1764. He was sired by Cade the best son of the Godolphin Arabian; his dam was by Steady, a fleet son of Flying Childers, his $g$ dam was by Partner; Partner by Jigg and Jigg by the Byerley Turk.

Wildair was a horse of high bleod and great performance; but he was beat by Mr. Warren's Sportsman, before he left England. In this country he was sire to Col. Sims' Wildair Sultana and other noted racers. He was taken back to England about the rear 1772. His stock proved excellent and were long in high repute. 


\section{LIST OF MORGAN HORSES.}

\begin{tabular}{|c|c|c|c|}
\hline AuBAY Horse & $\begin{array}{r}\text { PAGE } \\
262\end{array}$ & Baxter Horse & $\begin{array}{l}\text { PAUE } \\
269\end{array}$ \\
\hline $\begin{array}{l}\text { ArBAN Hors } \\
\text { Arabian Morgan }\end{array}$ & $\begin{array}{l}262 \\
263\end{array}$ & $\begin{array}{l}\text { Baxter Horse } \\
\text { Bardweil Horse }\end{array}$ & 209 \\
\hline Ashuelot Morgan, & 262 & Benton Horse & $2 \pi 2$ \\
\hline Allen Horse & 262 & Billy Root & 271 \\
\hline Andrews Horse & 262 & Birl Horse & 268 \\
\hline Americau Eagrle & 263 & Bliss Horse & 267 \\
\hline Andrew Jackson & 263 & Blue Morgan & 191,193 \\
\hline Addison & 263 & Bonaparte & 266 \\
\hline Bay Morgan & 265 & Boston Tiger & 268 \\
\hline Bay State Morgan 1st & 270 & Brock Horse & 269 \\
\hline Bay State Morgan 2d & 270 & Brown Morgan & 270 \\
\hline Bailey Horse & 265 & Belle of Saratoga & 194 \\
\hline Barker FIorse & 179,266 & Bulrush $144,160,163$, & 167,261 \\
\hline Bartholomew Horse & 266 & Bulrush Morgan & 264 \\
\hline Bachelder Horse & 268 & Buchanan Horse & 267 \\
\hline Blanchard Horse & 269 & Burbank Horse & 267 \\
\hline Black Morgan & 270 & Bussorah & 268 \\
\hline Black Lion & 271 & Clarke Horse & 273 \\
\hline Black Jack & $27 i$ & Clarke Horse & 276 \\
\hline Black Ralph & 193 & Charles Smith Horse & 273 \\
\hline Black Hawk. 172, 178, & 179,191 & Crane Horse & 179,273 \\
\hline $193,26 t$ & & Chamberlain Horse & 274 \\
\hline Biack Hawk Chief & 266 & Carpenter's Gray & 274 \\
\hline Black Hawk Eclipse & $26 \pi$ & Champlain & 275 \\
\hline B!ack Hawk Morgan & 267 & Champion Black Hawk & 86,87 \\
\hline Blick Hawk Napoleon & 269 & $2 \pi 5$ & \\
\hline Blach Hawk Prince & $2 \% 0$ & Charley & 275 \\
\hline Jlack Hawk. Jr., Ist & 272 & Chicago Jack & 194 \\
\hline Mlack Hawi, Jr., 2d & 272 & Carleton Horse & 276 \\
\hline Black Hawk Maid & 191,393 & Challenge & 276 \\
\hline Black Hawk Sherman & & [329] & \\
\hline
\end{tabular}


Childs Fiorse

Clements Hor'se

Clifton

Cock of the Rock

Colby Horse

Coos Morgan

Comet

Daris Horre

Deerfield Morgan

Don Juan

Dubois Horse

Ethan Allen

Ethan Allen 2d

Euperor

Enfield Horse

Esty Horse

Falcon

Falcon 2d

Farner's Beauty

Farrar Horse

Feuton Horso

Flint Horse

Fox

Fox Morgan

Flying Cloud 1st

Flying Cloud $2 a^{\circ}$

Flying Horgan

Flying Morgan Sprout

$194,195,279$

Flying Morgan of Petersham 281

Gates Horse

28.2

Grainite State Morgan

Granite State

Green Mountain 1st 282

Green Mountain $2 d$

Green Monntain $3 d$

Green Mountain, Jr

General Gifford 1st

General Gifford 2d

Geveral Gifford $3 d$
PAGE

273 General Gifford, Jr

274 General Taylor

274 General Cook Horso

273 Glines Horse

27:3 Gifford

275, 311 Gifford Morgan

276 Gifiord Morgan, Jr

277 Goodale Horse

277 Goodale Horse

276 Golden Eagle

277 Gray Hawk

$192,193,287$ Hawkins Horse

278 Hall Horse

277 Harlow Holse

278 Hackett Horse

279 Hampden

281 Hebard Horse

281 Henry Clay

231 Hubbard Horse

280 IIubbard Horse $2 d$

PAGE

285

284

283

284

179,284

73

285

282

283

286

195

146

286

287

195,287

287

287

195

286

288

287

281 Ives Horse

288

280 Justin Miorgan $25,26,92,17.5$

281 Jemie

288

279 Jerry

279 Karby IIorse

288

289

289

289

194

289

283

235 Knilght' $\mathrm{Horse}$

195

286 Lady Sherman

191, 192

Lady Sutton,

Latham Horse

289

230

290

290

291

292

298 


\begin{tabular}{|c|c|c|c|}
\hline & PAGE & & PAGE \\
\hline Major Gifford & 299 & Morgan Fusion & 301 \\
\hline Melvin Horso & 293 & Model Morgan & 292 \\
\hline Merriman Horse & 294 & Mountaineer & 302 \\
\hline Messer Horse & 300 & Moody Horse & 291 \\
\hline Morgan Lion & 290 & Mountain Eagle & 299 \\
\hline Morgan Trotter & 179,291 & Morrill Horse & 301 \\
\hline Morgan King & 291 & Myriek Horse & 300 \\
\hline Morgan Rat & 291 & Nearing Horse & 302 \\
\hline Morgan Tiger & 291 & Newton Horse & 302 \\
\hline Morgan Cæsa & 195,292 & Newell's Gray & 302 \\
\hline Morgan Star & 293 & Nieholas & 303 \\
\hline Morgan Champion & 293 & Nimrod & 303 \\
\hline Morgan Napoleon & 293 & Niles Horse & 303 \\
\hline Morgan Comet & 293,301 & North Horse & 302 \\
\hline Morgan Chief & 294 & North Star & 302 \\
\hline Morgan Figure & 294 & Old Morrell Horse & 304 \\
\hline Morgan Pestboy & 294 & One Eye & 303 \\
\hline Morgan Defiance & 294 & Orleans Flying Morgan & 303 \\
\hline Morgan Dragon & 294 & Panl Clifford & 304 \\
\hline Morgan Eaglo & 192,295 & Peacock Morgan & 305 \\
\hline Morgan Emperor $\mathbf{1 7 9}$, & 194,295 & Peters' Morgan & 306 \\
\hline Morgan Emperor 2d & 296 & Parks Horse & 306 \\
\hline Morgan Eclipse & 295 & Pike Horse & 304 \\
\hline Morgan Empire & 296 & Pizarro & 192 \\
\hline Morgan Hunter & 296 & Pleasant Gale & 306 \\
\hline Morgan Chief & 296 & Plato & 305 \\
\hline Morgan Robbin & 297 & Pope Horse & 305 \\
\hline Morgan Rattler & $29 \%, 298$ & President & 306 \\
\hline Morgan Recruit & 297 & Prince Albert & 304 \\
\hline Morgan T'igrer 1st & 297 & Putnain Horse & 304 \\
\hline Rforgan Bueeplaalus & 298 & Putnam Horse 2d & 305 \\
\hline II Iorgan General & 298 & Randolph Morgan & 306 \\
\hline MIorgan Sultan & 299 & Ramsey Horse & 307 \\
\hline Morgan Trustee & 299 & haven & 308 \\
\hline MLorgan Chieftain & 293 & Revenge & 308 \\
\hline Morgan Black Hawk & 300 & Pip Van Winkle & 307 \\
\hline Morgan Traveller & 300 & Rising Sun & 309 \\
\hline Mrorgan Traveller $2 d$ & 300 & Robin & 307 \\
\hline Mrurgan Tally Ho & 195,300 & Rolland Horse & 307 \\
\hline Nurgan Tiger $2 d$ & 301 & Romeo 1st & 203 \\
\hline
\end{tabular}


Romeo 2d

Rounds Colt

Rowel Horse

Royal Morgan

Sawyer Horse

Scott Horse

Searcher

Selim

Sherman 144, 150, 155, 163, 169 $176,178,179$

Sherman Morgan 1st

Sherman Morgan 2d

Sherman King

Sherman MIorgan Defiance

Sherman Black Hawk 193, 194 311

Shirtliff Horse

Sir Charles

Smith Morgin

Sterens Horse

Stockbridge Chief

Stranger

Taylor Horse

Tecumseh

Turner's Black Hawk

Twin Morgan

Vermont

Vermont 2d

Termonter

Vermont Boy

Vermont Champion

Vermont Morgan
PAGE

308 Vermont Morgan Champion 315

307 Vermont Chief $\quad 316$

309 Way Horse 318

179, 309 Walker Horse. $\quad 319$

313 Wellington Horse 317

312 Wheeler Horse 317

313 White Mountain 317

313 White Mountain MIorgan 318

Whalebore $\quad 319$

Wiley Colt 317

310 Wild Air 318

312 Windsor Morgan 318

311 Woodbury 319

311 Woodbury 2d 316

Yankee Boy 321

Young Americe $\quad 320$

312 Young America 2d 320

311 Youig Bulrush 322

313 Young Bulrush 2d 319

:313 Young Bulrush 3d 320

193,311 Young Bulrush 4th $\quad 320$

312 Young Burbank 1st $\quad 319$

314 Young Burbank 2d 321

314 Young Black Hawk 321

314 Young Cæsar 321

314 Young Flying Morgan 322

315 Young Hubbard 322

315 Young Latham 322

316 Young Morrill 322

192 Young Morgan Emperor 321

315 Young Morgan Eclipse 321

316 Young Morgan Empire 320 


\section{LIST OF H ORSES}

(YOT MORGANS)

\section{MENTIONED IN THIS WORK.}

Apollo
Barney Heury
Betty
Bloody Buttocks
Blank
Byerly Turk
Blockesby
Celia
Childers
Cock of the Rock
Carson Horse
Croft's Partuer
Cripple
Columbus
Curwen's Bay Barb
Dey of Algiers
Diomed
Duroc
Dying Sergeant
Eclipse

$\begin{array}{rlr}\text { PAGE } & & \text { PAGM } \\ 22 & \text { Engineer } & 24 \\ 324 & \text { Flora Temple } & 194 \\ 177 & \text { Fag Down } & 81 \\ 177 & \text { Forest Maid } & 192 \\ 22 & \text { Florizel } & 22 \\ 22,127 & \text { Gabriel } & 325 \\ 177 & \text { Gimcrack } & 177,178,165 \\ 177 & \text { Gray Eagle } & 173,191 \\ 22 & \text { Godolphin Arabian } & 19,177 \\ 25,323 & \text { Greswood's Partner } & 177 \\ 324 & \text { Greyhound } & 177 \\ 22,127 & \text { Hamiltonian } & 22,25,81 \\ 177 & \text { Hambletonian } & 22,23 \\ 193 & \text { Heury } & 25,324,326 \\ 127 & \text { Jigg } & 22,127 \\ 25 & \text { King Herod } & 22 \\ 22,165 & \text { Lady Miller } & 81 \\ 25,165 & \text { Lady Moscow } & 191 \\ 191 & \text { Lee Boo } & 194 \\ 25,165,356 & \text { Lady Suffolk } & 191,194 \\ & & \text { [833] }\end{array}$


334 LIST OF HORSES NOT MORGANS.

$\begin{array}{lrlr} & \text { PAGE } & & \text { PAGE } \\ \text { Lady Swan } & 192 & \text { Shark } & 22 \\ \text { Leonides } & 324 & \text { Sir Walter } & 25,323 \\ \text { Lindsey's Arabian } & 126 & \text { Sir Charles } & 25,325 \\ \text { Messenger } 23,24,25,81,165 & \text { Soto } & 192 \\ \text { Miller's Damsel } & 24 & \text { Sal } & 191 \\ \text { Miss Elliott } & 177 & \text { Sir Archy } & 22,165 \\ \text { Mambrine } & 23,81 & \text { Signal } & 324 \\ \text { Murdoch } & 193,194 & \text { Tartar } & 22 \\ \text { Minton's Traveller } & 127,128 & \text { Tippoo Saib } & 81 \\ \text { Postboy } & 25,325 & \text { Tramp } & 195 \\ \text { Quicksilver } & 323 & \text { True Briton } & 101,103,116,127 \\ \text { Regulus } & 24 & \text { Turf } & 24 \\ \text { Revenge } & 144,146,148 & \text { Whalebone } & 195 \\ \text { Rose of Washington } & 192 & \text { Wild Air } & 104,327 \\ \text { Sampson } & 24 & \text { Xoung Hamiltonian } & 324 \\ \text { Sport } & 127 & & \\ \text { Spectator } & 22 & & \end{array}$




\section{N D EX.}

Agricultural Fairs, training for exhibition at $\quad-\quad 233$

" " trotting matehes at - _ . 196

Arabian Horses, origin and Classification $\quad-\quad-\quad-\quad 12$

Arabian Horse, first importution of into England - - 18

Affidavit of John Stearns conceming Justiu Morgan - $\quad-97$

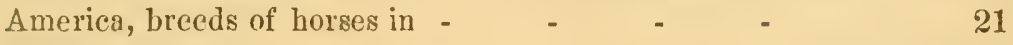

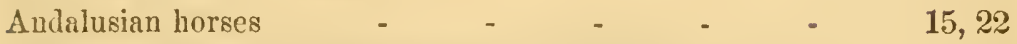

Associations for improring the breed of horses - - 216

Barb, characteristics of the $\quad$ - $\quad$ - $\quad$ - $\quad$ - $\quad 12,15$

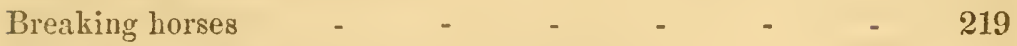

Breed of horses, best methods of improving - - - $\quad 200$

breeding of horses, medium size, best for - - - - $\quad 213$

Breeding animals, selection of - $\quad-\quad$ - $\quad-\quad$ - 205

Business horse, character and traits required for - $\quad-\quad 55$

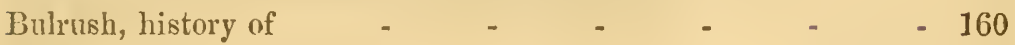

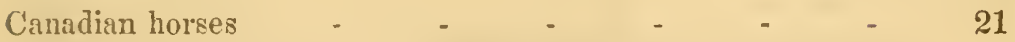

Certificate of Committee of Vermont State Ag. Soc. awarding

first premium to D. C. Linsley for Essay on Morgan Horses 8

Certificate of David Goss to Portrait of Justin Morgan - 9

" Solo. Steele " " " " 99

" Dan'l Baldwin " " " $\quad$ " $\quad$ - 9

Cleveland Bays $\quad$ - $\quad$ - $\quad$ - $\quad$ - $\quad$ - $\quad$ - 20

Characteristics of the MLorgan Horee - _ _ - 72-91

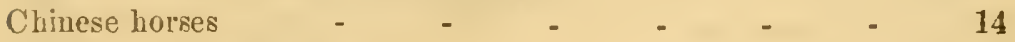

Criticisms on Morgan Horses _ _ _ _ _ $\quad$ - $\quad$ 72-91 
Coach horse, English -

Conestoga horse -

Color of a good horse

Correspondence relative to Origin of Morgan Horse - - 98

Dams, Arabs, trace the pedigrees of horses through the $\quad-13$

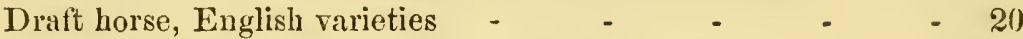

Dain of Justin Morgan

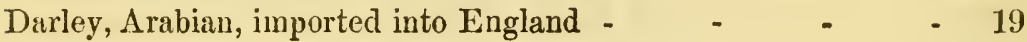

Diomed

Driving upon the Roa

Dongola horses

Dutch horses

Eclipse, description of

English Race Horse, deterioration of

Euglish Horses

Egypt, the horse is traced to

Finland Horses

Flanders, importation of horses from, into England

Feeding and driving on the Road

36,38

Fenton Horse, history of

Flemish horses

- 147

French horses

15,22

German Horses

German "running horses"' imported into England

General Gifford, the representative of the race

72,73

Gifford Moroan

73

Gimerack, Memoir of

Godolphin Arabian, imported into England

Hawkins horse, history of

Hamiltonian horse, pedigree of

Hack horses, kind most souglit for

Harness, qualities of a horse to appear well in . 
History of the Horse

PAGE

History and deseriptions of Stallions sired by Justin Morgan

History of Justin Morgan

History of Revenge

- $131-143$

Hunter, the English

- 148

History of Woodbury

19,40

$$
\text { "Bulrush }
$$

Horses (not Morgan), List of

Horse, the companion and serrant of man

Horses, Arabian

" Dongola

" Toorky

" Chinese

"Persian

": Flemish

“ Dutch

“ Italian

" Netpolitan

Andalusian

German

Humgarian

Swedish

Russian

English

Conestoga

Cauadian

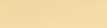

- 10

\section{" Kind most sought for}

India, horses of

Italian horses

Indiana, character of horses in

Iceland, horses of

Importation of horses from the Levant into England

" German horser into England

Arabian horses horses from Flauders into England

66

Darley Arabiau

66

Jnstin Morgan, Memoir and description of 
Justin Morgan, Dam of

“ Reported Sire of

Justin Morgan 2d, Letter from

Kentucky, character of the horses of

Letter from Justin Morgan $2 d$

99,104

George Barnard -

97

" M. O. Walker,

" Mr. Weissinger

- 89

" Frederic A. Weir

102

" Milo June

List of Morgan horses mentioned

" horses (not Morgan) nientioned

Morgan Stallions, pedigrees and description of -

- 260

Messenger, pedigree of

Morgan horses, performances of -

\begin{tabular}{|c|c|c|c|c|c|c|c|c|}
\hline 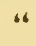 & present $\mathrm{r}$ & alue of & - & - & - & & - & \\
\hline “ब & origin of & - & - & - & & , & & \\
\hline & list of & - & - & - & & - & & \\
\hline & a distinet & breed & - & - & - & & - & \\
\hline & hardiness & and eno & Aurance of & - & & - & & \\
\hline & peculiar a & daptatic & on to the $R o$ & sad and & & ener & $1 \mathrm{us}$ & \\
\hline & instance 0 & of their & encurance & - & - & & - & \\
\hline & descriptio & n of & - $\quad-$ & - & & - & & \\
\hline & differ fror & in the $\mathrm{C}$ : & amadian, & - & - & & - & \\
\hline & diflerent & dmilies & of, charactes & ristics & & - & & \\
\hline & but three & distinet & fiumilies of & & - & & - & \\
\hline & stock in & Termont & ; $\quad-$ & - & & - & & - \\
\hline & High Pri & ces of & - & - & - & & - & \\
\hline
\end{tabular}

Narragansett Pacer

Neapolitan horses

New England character, horses of

New York character, horses of

Norman horses

Onnibus horses, kind of horses most sought for 
Pennsylvania, character of horses of

Persian horses

Performances of Morgan horses -

Preparation for exhibition

Pedigree of Hamiltonian horse -

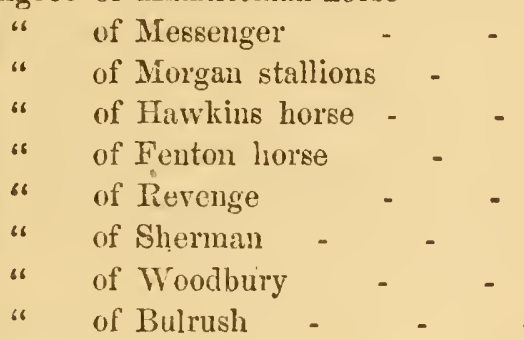

Purchasing horses

Races established at Hyde Park

Races elosed by Cromwell

Revenge, history of

Riding manly and healthful cxercise

Roadsters

Russian horses

Selection of breeding animals

Serrices, change in kind of, required

Services rendered by the horse -

Sir Archy

Sherman, history of

Southern States, character of horses of

Spanish horses

Sporting horses, demand for

Stallions sired by Justin Morgan

Swedish horses

Size, medium, best for breeding

Size best adapted for service

\section{Tartar horses}

Tonrkomans, horses of

Toorky breed of horses

'T'orkistan, horses of

'Trotter preferred to the racer 
Trotting matches at Agriculturul Fairs PAGB

Truck horses

True Briton, reputed sire of Justin Morgan

'Trotting matches, the first in America

Unsounduess

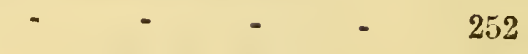

White Turk, purchase of

Wild horses, where found

Woodbury, history of

Weight of Morgan stallious

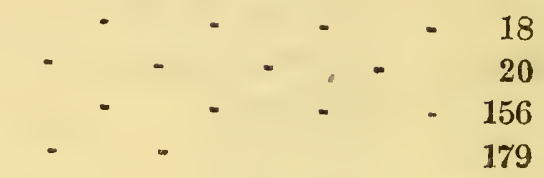




\title{
THE BEST WORI ON THE HORSE.
}

\author{
PRICE ONE DOLLAR.
}

C. M. Saxtoy \& Co. have just pubuished

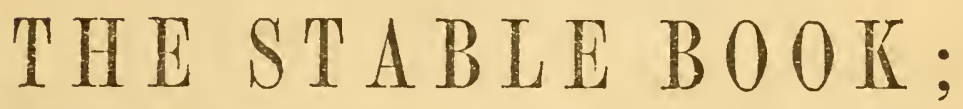

A Treatise on the rilanagement of Elorses, in relation to Stabling, Grooming, Feeding, Watering, and Working.

BY JOHN STEWART,

Veterioary Surgeon, and Professor of Veteriaary Jedicino in the Andersonian University, Glaggow.

WITI NOTES AND ADDITIONS ADAPTING IT TO AMERICAN FOOD \& CLINATT

$$
\text { BY A. B. ALLEN, }
$$

Elitor of the American Agricalturist.

\section{ILLUSTRATED WITH NUMEROUS ENGRAVINGS.}

C ONTENTS.

Ci1s. I.-Siabling, Construction of Stables, of,-Principles of Feeding, Practice of FeedVentilation of Stables, Appendages of Stables. ing, Pasturing, Soiling, Feeding at Straw

CuAP. TL. _ Stable Operations, Stable Men, Yard.

Grooming Operations of Decoration, Manage- CraP. VI.-Water.

ment of the Feet, Operations in the Stable. CHAP. VII.-Service, General Preparation

Cirap. III.-Stable Fistraints, Accidents, for Work, Physiology of Muscular Exertion, Habits, Virees.

CHAP. IV.-Warmh.

CydP. V.-Food-Arifles of, Composition Chap. VIII.-Management of Diseased and of, I'reparation of, Assimilation of, Indigestion Defective Horses, Medical Attendance.

"I have aimed in this Wrork TO MARE PRICTLCE TAE MASTER OF THEOR Y, and have endeavored to arrange the whole subject into divisions which will render every part of it casily understood, and easily referred to by every one."-Author's Preface.

"The Horse has been a favorite stucly with me fron childhood, and for twenty jears I have been more or less engaged in breeding and rearing them, on my own farm, and breaking and fitting them for market. I also had, during a residence of two years in Europe, the advantage of Studying the Stable Economy of large Military Establishments, and to inform myseif by personal inspection on the subject of the Horse in general, and particularly his rearing and slable treatment, and in so doing examined alike the Thorough Bred. the Huntcr, the Foadster, the Farm and the Dray Lorse. A. B. Alles." -American Editor.

\section{The llorse's Foot, and Iow to keep it Sound.}

\author{
WITH ILLUSTRATIONS.

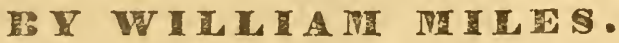

Price : Paper, Twenty-five Cents. Cloth, Fifty Cents. 
C. M. Saxton \& Co., Publishers, 140 Fulton Street, New York.

\section{T FI E \\ 6656 \\ AMERICAN \\ CATTLE \\ DOCTOR.}

Eleven Thousand Copies Sold! Price One Dollar.

\section{Dadid's Great Worle on the \\ DISEASHS OF CATTLE;}

CONTAINING

The necessary information for preserving the health and curing the diseases of Oxen, Cows, Shcep, and Swine ; with a great variety of original receipts and valuable information in reference to

\section{FARM AND DAIRY MANAGEMENT, WHERESY}

\section{Every Jan can be His Own Cattle Doctor.}

\section{BY GEORGE H. DADD. \\ Veterinary Surgeon, of Boston.}

"We have carefully examined the Book, and can fully recommend it to all who own Cattlo, as a safe and reliable guidc. The author is an experienced Farrier, and as such his prescriptions and general instructions may be relied upon." - PHIL. NEws.

Every Farmer, Millkman, Drover \& Butcher should own this Book. ORICE ONE DOLLAR.

\section{YOUATT \& MARTIN ON CATTLE.}

A. Treatise on Breeding and General Management of Cattle; Comprising a Full History of the various Races; their Origin, Breeding and Merits; their capacity for BEEF and MiLk; the Nature aud Treatment of their Diseases; the whole forming a Complete Guide for the Farmer, the Amateur, and the Veterinary Surgeon. With One Hundred Mllustrations.

A New Edition, edited by Hon. Ambrose Stevens. Frice $\$ 125$

\section{GUENON ON MILCH COWS :}

A Treatise on Milch Cows, whereby the Quality and Quantity of Mrils which any Cow will give may be accurately determined by observing Natural Marks or External Indications alone; the length of time she will continue tu give Milk, \&c., \&cc. By M. Francis Guenon, of Libourne, France.

Translated by Nicholas P. Trist, Esq. : with Introductory Remarks and Observations on tho Cow and the Dairy, by JOHN S. SKINNER.

With Numerous Illustrations. Price, neatly done up in Paper Covers, $37 \frac{1}{8} \mathrm{cts}$. Cloth, $62 \frac{1}{6}$ ats. 


<smiles>CCCCCCC</smiles> 


\section{LIBRARY OF CONGRESS}

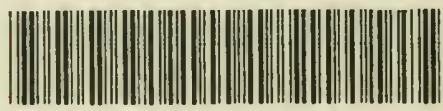

0002656752A 